\title{
Invention of the Market: The Political Economy of Everyday Life in Late Socialist Cuba
}

\author{
Roberto I. Armengol
}

Charlottesville, Va.

B.A. in Liberal Studies, University of Delaware, 1999

M.A., University of Virginia, 2006

A Dissertation presented to the Graduate Faculty of the University of Virginia in Candidacy for the Degree of

Doctor of Philosophy

Department of Anthropology

University of Virginia

December 2013

Ira Bashkow, Chair

Peter Metcalf, Committee member

Frederick H. Damon, Committee member

Brian P. Owensby, Graduate School representative 
(C) Copyright by

Roberto I. Armengol

All rights reserved

December 2013 


\begin{abstract}
The Cuban people have faced a prolonged period of economic crisis since the collapse of the Soviet Union and the end of favorable subsidies from the socialist bloc. In that time, the government has alternately initiated and curtailed market-oriented economic policies that promote small-scale entrepreneurship, known in Cuba as cuentapropismo. Such activity and the social arenas in which it takes place have grown tremendously since the early 1990s, touching nearly everyone's life. Outside analysts tend to characterize this rapid growth in self-employment as evidence of the natural forces of capitalism breaking through the stranglehold of communist ideology, while the authoritative discourse of the socialist state itself often regards these changes as encroachments of "the market" necessary for the preservation of the communist project. In this dissertation, I demonstrate how creative entrepreneurship among low-income workers in urban Cuba is actually carried out through dense networks of reciprocity and coded in the moral principles of invento, or invention. Relying on ethnographic data collected in and around a large farmers market, I argue that the morality through which my informants construct their relationships is a form of "competitive solidarity" that produces, in effect, a subaltern political struggle against state socialism as well as global capitalism. While this might seem paradoxical, both capitalism and socialism share modernist assumptions about human nature that are at odds with the way ordinary Cubans live their lives. By way of contrast, I show how the state's own discourse and ritual practices have of late promoted the values of possessive individualism, consumption, and capital accumulation, leading to an acute moral dissonance that has yet to play itself out.
\end{abstract}


What my informants playfully call invento is in this sense a grassroots "invention of the market," in which relations of solidarity are realized through market transactions carried out in an ethos of gift exchange. These practices pose a challenge to the basic assumptions of formal economic theory - the abstract "invention of the market" that predominates in social science and takes the maximizing, self-interested individual as its starting point rather than its product. In this way, my reading of the political economy of everyday life in late socialist Cuba builds on a long history of anthropological critique questioning such assumptions, largely on the basis of cultural contexts where gifts are central and commodities are peripheral. But beyond showing how market exchange is always embedded in moral systems, this dissertation ultimately insists on theorizing markets themselves as already moral. This is to say, they are always organized with respect to variable moral premises that necessarily have political implications. In this light, alternative market paradigms — in Cuba and beyond — have the potential to foster a pragmatic oppositional politics. From a theoretical perspective, what I am proposing is that social science wrest the idea of "the market" once and for all from the straitjacket of idealized capitalism: In adopting a neo-Maussian framework, we can attend more closely to the reciprocal relations of mutual support and obligation that can and often do operate through markets, not just in spite of them. 
To my mother and father 


\section{ACKNOWLEDGMENTS}

This work would not have been possible without the generosity and trust that so many unnamable people in Cuba, too many to count, have afforded me over the years. I thank especially those who befriended me in the neighborhood where I did most of my fieldwork, and in the neighborhood where I lived. On different ends of Havana, these two worlds formed the bookends to an urban landscape in which, I will argue, reciprocity plays a central role. What follows in these pages is the paltry sum I have to offer in return for the invaluable gifts of time and knowledge, meals and celebrations, coffee and comfort, that my friends offered me. It pains me that I cannot name any of them, because they are real people to me, with real names and faces. For all the usual reasons, those who appear here appear under pseudonyms. If in many instances I have drawn on the names of my own kin to replace theirs, it is because I consider many of them as family.

Which brings me to my actual family. I would like to thank above all my parents, Carlos E. Armengol and Ileana Piedra Armengol, for never losing hope in me. Their love and support knows no bounds, extending even to the final and careful proofing of this text. I have dedicated this thesis to them, with all the love I can muster. My brother, Carlos E. Armengol Jr., and my sisters, Ileana Abounader, Beatrice McNeff, and Sylvia Kunz, helped raise me and continue, with their own families, to fill my life with happiness and good advice. I thank Charlie in particular for putting up with me in Charlottesville, which has always been his home more than mine; for getting me out of trouble since I was born; and for reading an earlier draft of this work, word for word. He provided helpful edits and took me to task on some parts that made no sense. 
My children, Lucía Ileana and Roberto Máximo, have long been wondering when Papi would finish his dissertation. Lucy lived in Cuba during the longest stretch of my fieldwork, turned three there, and still remembers helping her mother hail taxis on Calle 23. Max, born after our return, has lived there only in dreams but knows it well enough. It's an odd thing for a grownup to say this about children, but their patience with me has been admirable and instructive. That, and the laughter and lightness they bring every day into my life keeps me going when nothing else, ni tabaco ni azúcar, seems to work.

There are so many others in my vast Cuban clan who have helped make me who I am, and make me a better person, a few of whom deserve special mention for reasons they will understand. In Cuba: Silvia Elena Armengol, Guillermo Armengol, Patricia Armengol, Emilio Biosca, the late Mariano Vivanco, Bishop of Matanzas, and all of the Vivanco family in San Antonio de los Baños. In the United States: Armando Armengol, María Conchita Méndez, the late José Clemente Vivanco, Hilda Armengol Bertrán, the late Arturo Olivera, with Betty Olivera and all their family, Jacqueline Armengol Shimer and Adam Shimer, Alex Piedra and Amy Shickel Piedra, Cristina Armengol Williams and Matthew Williams, Adam Armengol, Kevin Armengol, Leticia Pérez Hansen and James Hansen, Lorenzo Javier Pérez and Billie Gay Pérez, Yolanda Piedra Ruisánchez and José M. Ruisánchez, Yolanda Ruisánchez Gruendel and Darren Gruendel, Isabel Armengol Darragh and Edward Darragh, Mariano Piedra and Claudia B. Piedra, Ignacio Armengol and Myrna Millán Armengol, Victoria Armengol Gempton, Laura Armengol Troche, and Juan Luis Betancourt. And of course my loving grandparents, models of devotion and perseverance: Yolanda Vivanco Piedra and Joaquín H. Piedra; and the late 
Hilda Olivera Armengol and Eladio E. Armengol, may their spirits not be too offended with my account of their homeland.

Now the task of acknowledging all of my personal and intellectual debts seems increasingly insurmountable as I think of the friends and colleagues who have shared in my trials and whose thinking has influenced my own. It seems unjust to list them and say little more, but it would require another dissertation to tell them everything I wish I could. There are those who came of age with me: Carlos Plá, Mark E. Jolly-Van Bodegraven, Eric Santa-Cruz, Iván Santa-Cruz, Alan Díaz, and Victor Arrieta, and all those with whom I ran on the Belén Jesuit Prep cross-country team. Then there are my first mentors, who believed in me when, as young people often do, I didn't believe in myself: Rafael Ledesma, Cristina Ramírez, Beatriz Jiménez, Carlos Barquín, Kathleen Duke. There are those who were my editors, teachers and colleagues during my life as a journalist and a journalist-in-training. They prepared me unwittingly, in ways large and small, for what I really wanted to do. Especially: Harris E. Ross, Dennis Jackson, Kristin Collins, Leanne Milway Chabalko and John Chabalko, Leo Shane III, Ryan Cormier, John Sweeney, Jef Feeley, David Gilmartin, Gary Weckselblatt, Joan Bastel, Patrick Lester, Wyatt Andrews and Hawes Spencer.

And then there are those who have stuck it out with me through various stages of our graduate studies, some of the sharpest thinkers and nicest people I know. I am especially grateful for the friendship, support and feedback I received in the write-up stage from David Flood, Jason Hickel, Arsalan Khan, Sue Ann McCarty, Julie Starr, Jack Stoetzel and Rose Wellman. Thanks are due also to these many others, listed roughly in the order 
I met them: Harri Siikala, Beatrix Arendt, Njoki Osotsi, David Strohl, Amy NicholsBelo, Lisa Stewart, Carrie Heitman, Mieka Brand Polanco and Tony Polanco, Gareth Fisher, Clare Terni, Phillip Trella, Kent Wayland, Anna Lim, Claire Snell-Rood, Sheena Singh, Nathan Hedges, LuAnn Williams, Jonas Hart, Christopher Loomis, Dionisios Kavadias, Lucas de Carvalho, Viktoryia Kalesnikava, Justin Shaffner, Alessandro Questa and Beatriz Ruizpalacios, Lydia Rodríguez, Grace Reynolds, Dannah Dennis, Carolyn Howarter, and Kyle Edwards. Marian Viorel Anastasoaie and his erstwhile love Caroline Oger deserve special mention. I met Viorel and Caroline in the field. Viorel and I were each of us working on our respective ethnographies, both married at the time and raising small children and struggling to find and define ourselves: I with self-employed workers in Havana, he among the tobacco growers of Pinar. In our conversations with one another the germs of our arguments were born. So too was an abiding friendship.

Only now have I arrived at the institutional and professional foundations for this project, late to this task because I am quite simply terrified of what I owe to the people who taught me and the places that sheltered me. Kenneth J. Ackerman at the University of Delaware - the sort of teacher I wish I could be - first introduced me to the discipline; it is no exaggeration to say it's his fault I got here. Others at Delaware inspired me to pursue a doctorate in anthropology even though it was not my major. I thank especially Karen R. Rosenberg, Thomas R. Rocek and Donna M. Budani.

My graduate studies were possible thanks to generous financial and institutional support from the University of Virginia, in the form of a President's Fellowship in my coursework years, pre-field and language-study grants, a dissertation-away fellowship, 
travel funds for professional development, several teaching positions, and various other odd jobs, including two unpaid but engrossing stints as an assistant editor of Anthropology and Humanism. UVa's Department of Anthropology could not have been a more welcoming place to grow as a scholar, and I will miss it tremendously.

The U.S. Department of Education funded my extended stay in the field with a Fulbright-Hayes Doctoral Dissertation Research Abroad Fellowship. The Fundación Fernando Ortiz in Havana, under the leadership of the esteemed Miguel Barnet, provided me with the official status I needed to conduct ethnographic research in Cuba. I thank also the librarians of the Cuban Heritage Collection in Miami and the Biblioteca Nacional José Martí in Havana, for their help tracking down relevant archival materials.

When I returned from the field, I found myself by dumb luck working as a teaching and later research assistant for Deborah Johnson in the program in Science, Technology, and Society of UVa's School of Engineering and Applied Science, where I received nothing less than a second graduate education. In that period I also worked as a graduate student associate at the university's Teaching Resource Center, a venerable institution committed to faculty development, where I learned so much from my TRC mentors, Judith Regan, Marva Barnett, Dorothe Bach, Michael Palmer and Deandra Little. Finally, the Jefferson Scholars Foundation gave me the funding and a serene venue for writing up, just at the critical moment.

Outside of my ordinary course of study, there came helpful support and feedback from scholars at the Cuban Research Institute of Florida International University, especially Uva de Aragón; from the Cuba Study Group; and from the Association for the 
Study of the Cuban Economy, especially Ted Henken, Enrique S. Pumar, Jorge PérezLópez, Roger R. Betancourt and Lorenzo L. Pérez. I also thank Sergio López for involving me with his work on the Revista de Antropología Iberoamericana. At Washington and Lee University, where I served for one year as an adjunct instructor, I enjoyed the utmost collegiality of all the faculty in the sociology and anthropology program, especially David R. Novak, Krzysztof Jasiewicz, Jonathan Eastwood, Harvey Markowitz, Alison Bell, Sean Devlin and James Flexner.

As all scholars, I owe a big thanks to the many students I've taught over the years, and who taught me in turn. I acknowledge especially those (too many to name) in a handful of courses that shaped my thinking about Cuba and my research in general: "Political Anthropology - The State," "Making Cuba," and "Markets and Moralities," all at UVa; as well as "Cultural Theory," at W\&L.

But I should thank no one at all if not the professors at UVa without whose tireless dedication there would be no thesis for which to write acknowledgments in the first place. Ira Bashkow has been at my back, prodding, teaching, reading, from the very beginning. The structure of this work formed in the conversations we had on our many long and pleasant walks. Peter Metcalf introduced me in earnest to the history and theory of the discipline. Having such an elder statesman of anthropology as a friend and mentor is truly an honor. Frederick H. Damon stands guilty of bringing me to UVa to begin with. Later, he came to my rescue with his most excellent wit and even better scholarly counsel. Brian Owensby, a historian with the sensibilities of an anthropologist and the acuity of an attorney, shared with me his profound knowledge of the Latin American 
experience. I must also thank Richard Handler, who ushered me through my master's degree and whose influence on my understanding of what anthropology is - and is good for - endures; I'll always consider myself one of his students.

Beyond these committee members past and present, I am indebted to the many kind and engaging scholars at UVa who have offered helpful commentary, intellectual guidance and continued moral support: J. David Sapir, Edith Turner, Roy Wagner, Susan McKinnon, Kath Watson, George Mentore, Wende Marshall, Hanan Sabea, Herbert “Tico” Braun, Ekaterina Makarova, Gustavo Pellón, Eve Danziger, Lise Dobrin, Daniel Lefkowitz, Dell Upton, Ellen Contini-Morava, Adria LaViolette, Ravindra Khare, James Igoe, Fraser Neiman, Catarina Krizancic, Siva Vaidhyanathan, Kathryn Neeley, Michael Gorman, Benjamin Cohen, Bill Wilson and the late Dell Hymes.

I have saved for last the most difficult thank yous of all. I offer my sincere gratitude, tinged with remorse, to Ophelia Lenz, the mother of my children. She supported me through the first stage of my graduate career and joined me in the adventure of the field. In the end things did not turn out how either of us imagined. But we have to show for it two beautiful children and, for her part, some of the most genuine and compelling photography of Cuba that I know of. All of the photos included in these pages are hers.

Finally, I thank Sena Aydın, my dear partner and best friend, my fellow Maussian, and my fiercest critic, for her love — at times tough, at times hurtful, but true. I might well not have finished without the solace of her tender affection or, for that matter, without her candid assurance that she didn't care whether I did or didn't. Only time will tell what will become of you and me. 


\section{TABLE OF CONTENTS}

1. Introduction: Cuban Inventiveness and the Political Economy of Late Socialism ...............1

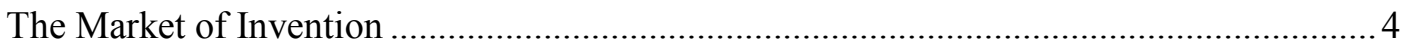

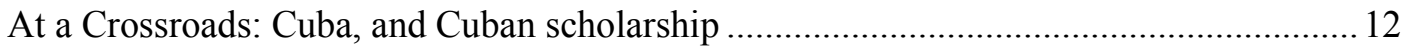

Economic Anthropology: Gifts, Reciprocity and the Market ...........................................2 24

Political Anthropology: Power, Hegemony and the Nation-State ................................... 41

The Anthropology of Socialism: It's Not Over Yet.......................................................... 50

Ethnographic Vertigo and the Dilemma of Quasi-Native Fieldwork..................................62

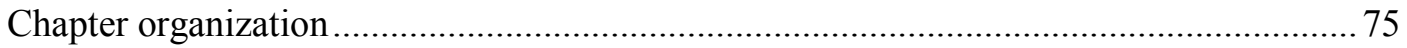

2. The Revolution and the Market...............................................................................................................78

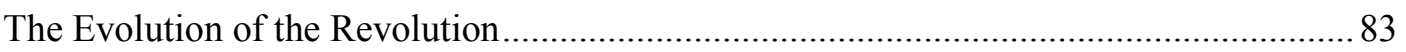

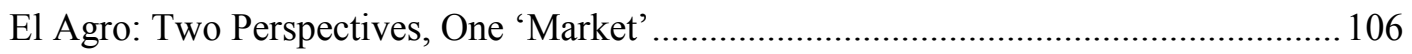

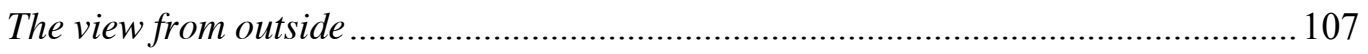

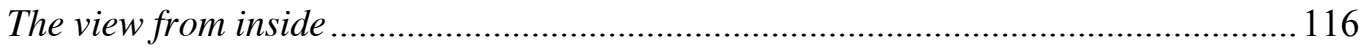

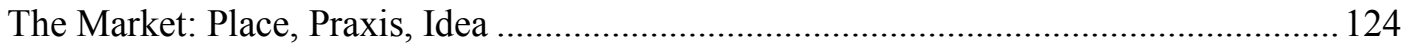

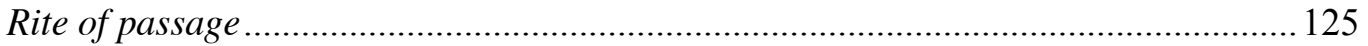

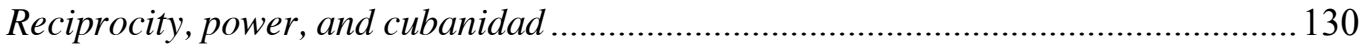

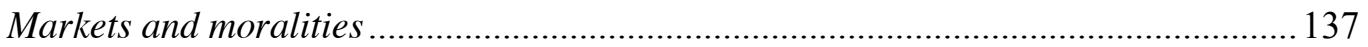

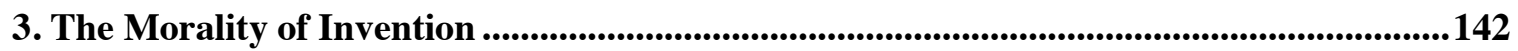

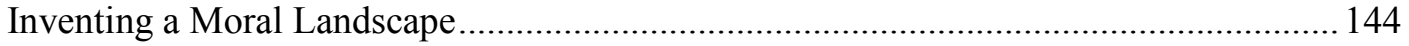

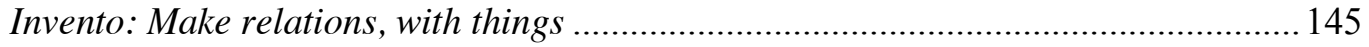

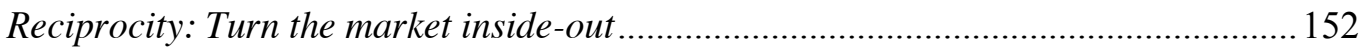

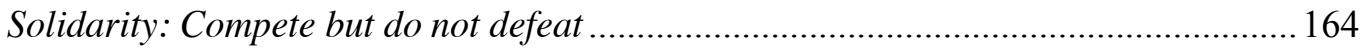




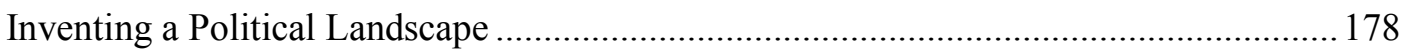

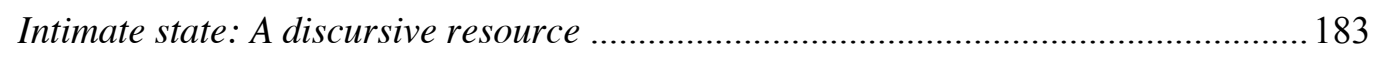

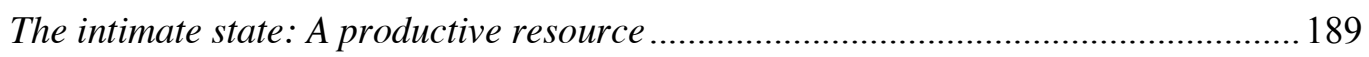

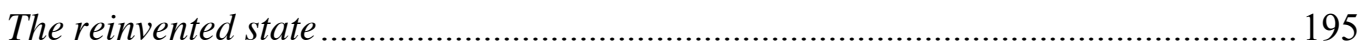

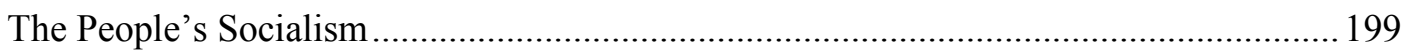

4. The Politics of Morality .............................................................................................................................202

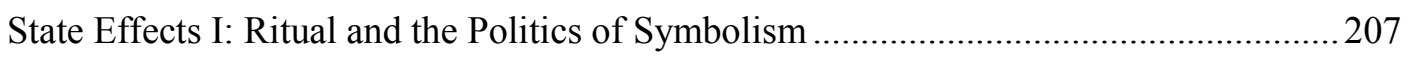

Authoritative discourse: Participation, unity and discipline ....................................210

Variable performance: Moral indiscipline and obedient indifference .........................223

The ritual production of moral dissonance ................................................................236

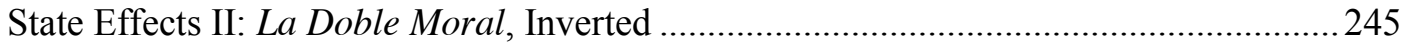

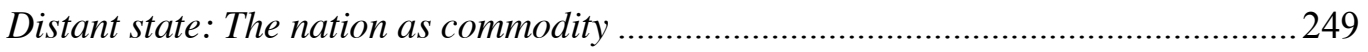

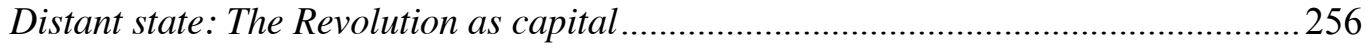

Distant state: The politics of consumption ................................................................264

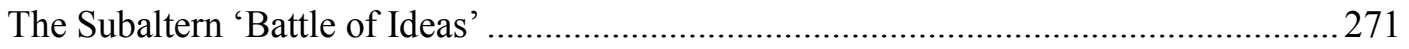

5. Coda: Reinventing Cuba, and the Anthropology of Political Economy ..............................274

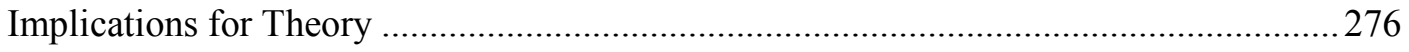

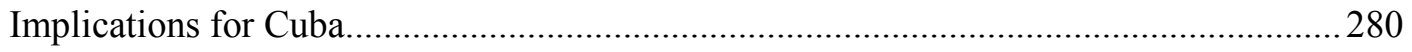

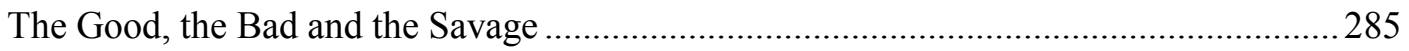

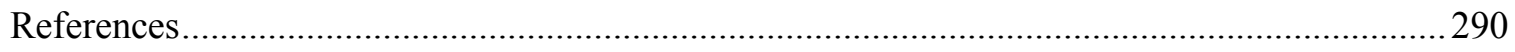




\section{LIST OF TABLES AND MAPS}

\section{TABLES}

Table 1.1 Sources of Domestic Revenue in Cuba, 2012

p. 13

Table 1.2 Remittances to Cuba: Some Characteristics

p. 13

\section{MAPS}

Map 1.1 Cuba, Key to the New World p. 20

Map 1.2 Cuba: Major Cities 20

$\begin{array}{lll}\text { Map 1.3 Central Havana } & \text { p. } 72\end{array}$ 


\section{LIST OF IMAGES}

\section{PHOTOGRAPHS (all photos by Opehlia Lenz)}

$\begin{array}{lll}\text { Photograph } 1.1 \text { Invento } & \text { p. } 8\end{array}$

$\begin{array}{lll}\text { Photograph } 1.2 \text { Havana skyline } 69 & \text { p. }\end{array}$

Photograph 1.3 Boys diving from the edge of the Malecón p. 70

Photograph 2.1 Cuatro Caminos, exterior view facing southeast p. 79

Photograph 2.2 Cuatro Caminos, interior view from above p. 80

Photograph 2.3 Cuatro Caminos, view of the produce stalls p. 116

$\begin{array}{lll}\text { Photograph } 3.1 \quad \text { Tarima kinship } & \text { p. } 151\end{array}$

Photograph 3.2 A bike shop near Cuatro Caminos, exterior view p. 158

$\begin{array}{lll}\text { Photograph } 3.3 \text { Bike shop, interior view } & \text { p. } 160\end{array}$

$\begin{array}{lll}\text { Photograph } 3.4 & \text { The jaba women } & \text { p. } 164\end{array}$

$\begin{array}{lll}\text { Photograph 3.5 A merolico and his wares } & \text { p. } 191\end{array}$

Photograph 4.1 Fidel at Cuatro Caminos p. 244

Photograph 4.2 Divisa store sticker shock p. 251

Photograph 4.3 Che as national symbol p. 256

Photograph 4.4 Che as symbol of consumption p. 258

\section{FIGURES}

Figure 4.1 "The United Vote: A revolutionary strategy" p. 217

Figure 4.2 "The United Vote Makes Us Strong” p. 221

Figure 4.3 "Social indiscipline is the cancer of society" p. 225 


\section{INTRODUCTION: \\ CUBAN INVENTIVENESS AND THE \\ POLITICAL ECONOMY OF LATE SOCIALISM}

When I first arrived in Havana, in 2003, most Cubans were still struggling through some of the worst hardships of the post-Soviet era. There were shortages of basic foodstuffs, frequent blackouts, difficulties traveling within and between cities, prices for just about everything beyond the reach of the typical income received from a state job. The Cuban government had called this the "Special Period," a euphemism adopted to characterize this long episode of economic crisis that gripped the country following the breakup of the U.S.S.R. Soviet subsidies and military support to the Cuban state ended abruptly in 1991, laying bare in the process many of the deep contradictions inherent in the island's socialist system, and paving the way for new ones. The Special Period saw the licensing of many small private businesses, the growth of many other illegal ones, the dollarization of the economy, the establishment of a dual currency system, an enormous spike in remittances from overseas, increased tourism and foreign investment, new trade with the United States (Cuba's nearest and dearest enemy), and the one-party system's successful transfer of power to a new head of state. No one knows how long the Special Period lasted, or whether in fact we're still in it. But as a term of art in the discourse of things Cuban, especially as compared with other key tropes (blockade or embargo? democracy or dictatorship? exile or mafia?), the idea of the "Special Period" has been met with unusually broad acceptance across the political spectrum and beyond the island. In one sense, this is surprising, given that it was coined by Fidel Castro himself, a polarizing 
figure to say the least. Then again, it makes perfect sense. It has, indeed, been a special time.

In my first, somewhat aimless, wanderings about the country, I was struck by the fact that those most willing to talk to me frankly about the contradictions of the Special Period as contradictions were usually also trying to sell me something. Raised in a capitalist culture, I confronted a vertiginous internal dilemma, one I would face over and over again during my fieldwork, in parallel ways: Were they telling me things I wanted to hear because they wanted me to buy this stuff — avocados and mangos, antique books, home-cooked meals, cuts of contraband beef, handcrafted trinkets and souvenirs, bootleg rum, tobacco or sex - or was there something more to the burgeoning of market enterprises in Cuba, something that defied the logic of the stories I had been reading back home in the U.S. press? The standard logic of the academic and popular discourse on Cuba (e.g., Corbett 2004, 2004; Miroff 2012; Olshan 1998; Sullivan 2012) holds that market reforms inevitably grew out of socialism's faults. This is a view to make Adam Smith proud: Cuban entrepreneurs, working legally and illegally, represent a class of people following their natural instincts - like and the rest of us, at last, to "truck, barter and trade" in their own self-interest.

There was something about this logic that didn't correlate well with the things I was seeing and hearing from the people who befriended me in Havana and other urban areas on the island. Over time, I came to doubt this meta-narrative of resurgent capitalism, as well as my own inclination to understand things in orthodox market terms, far more than I doubted the sincerity of my Cuban interlocutors. The self-employed workers, or 
cuentapropistas, who befriended me were telling me, through many idioms, acts and anecdotes, that as much as they wanted to sell me things, they also wanted to create social bonds of security, with me and with others, to be good socialists on their own terms. Paradoxically, many felt they achieved this best through the market, even (and often) at risk of intimidation and harassment by officials representing the same state that inculcated in them the value of reciprocity.

Admittedly, where there are markets there are shameless marketeers; I am not naive about the fact that the dollars I carried in my wallet (though never as plentiful as my friends believed), or the passport I kept in a safe in our apartment, held a certain allure for many of those I encountered. But this fact did not in itself make my status as foreigner or my role as patron central to my relationships with people as people. Nor are such feelings incompatible with the notion of "competitive solidarity" that I will introduce and explore at length in the pages to follow. Rather than interpolate simplistic economic models on everyday relations in Cuba, the point here is to inflect economic models with some of the nuance of socialist entrepreneurship during and beyond the Special Period.

A basic premise of this work — that economic systems are culturally specific arises from and responds to anthropological theory, but it is also automatically political. Our own "markets" never were so orthodox, and need not be constructed in the image of economic orthodoxy for its own sake. "Economism," as some scholars call it, has become a modern religion in which public discourse across the political spectrum is enthralled. Markets are and always have been inventions of a particular kind. Recognizing that not every person one meets in the field fits the mold of one's research findings, I nevertheless 
hope to show that a certain set of market practices in Cuba has discernible, counterintuitive patterns that deserve close attention. These people are not only "inventing" their livelihoods (as they themselves put it), but also, in the process, a moral landscape that stands in contrast to the logic of global capitalism as well as state socialism. They represent, I believe, an increasingly broad segment of Cuban society. And they have something to teach us about economics and political power, practically and theoretically. It is their invention of the market that motivates this story, but it is the invention of the market in the abstract to which, ultimately, their story speaks.

\section{The Market of Invention}

Carlito was one my finest teachers. He worked stocking beans and other goods for a stall at Havana's most important farmers market. It was opened in the early 1990s in the rundown remnants of a once stately building, now more than eighty years old, not far from the harbor. The place was airy and dingy, if not entirely cheerless, dimly lit with sunlight cascading variably through an expanse of cracked windows. Like the market itself, like so many Cubans I met, Carlito was something of an enigma to me, as I no doubt was to him: I, the American-born son of Cuban immigrants who had grown, inexplicably it seemed, sympathetic to many of the ideals of the Revolution, if not state socialism in the concrete. Carlito declared himself, as if to pester me, a conservative Republican, and endlessly vowed that he and his wife, a schoolteacher who worked with disabled children, were working toward leaving Cuba as soon as they could. We were 
each other's devil's advocate and in one respect, at least, every conversation we had was the same: we were trying to figure each other out.

This dissertation represents my attempt to articulate what I think I figured out from Carlito and many others. The picture I draw of everyday life in Havana during the socalled Special Period suggests new ways of understanding what Cubans call invento their inventive market practices — and, I hope, new directions in the anthropology of political economy.

Like Carlito, many thousands of young, urban, well-educated Cubans at the turn of the century dreamed of a better life in the United States or elsewhere in the developed world. Perhaps Spain, Sweden, Italy, wherever auspicious circumstances, a visa, and the bureaucratically elusive "exit permission" they needed from the government might lead them. (Exit permissions are no longer required, but securing a visa is still challenging and emotionally fraught.) At the same time, few really wanted to leave. They talked agonizingly about their country, la patria, their treasured Cuba, about the tropical weather and a life of friendships and social relations they did not want to let go. And many who have left under economic pressures in recent years have come, if not to regret their move, to mourn certain aspects of what they lost (e.g., Bosch and Domènech 2002).

There is a stock narrative about this discourse circulated regularly among the oldguard, hardline Cuban Americans, one also often heard on the mouths of mainstream American politicians of both major parties, and frequently repeated in U.S. press coverage about Cuba. These are the disaffected youth of Cuba's failed socialist experiment, we are told, with varying degrees of nuance involved in the telling. They flee 
political persecution in search of the freedom and economic opportunity afforded in the capitalist world. What nostalgia they have is entirely personal, deeply psychological, not especially inviting of social inquiry.

This narrative is not without some validity. But it leaves out some finer details that call for closer examination and, I think, alternative interpretations. The desire both to leave and to stay is a central contradiction of the Cuban experience, not new to the Special Period. It is more pronounced, now, this is true; but it runs deeper than it first seems. The paradox appears first as an outright rejection of the revolutionary project if not of the homeland itself. Yet this abstract separation of political and geographical landscapes is overdrawn. If we listen closely to the dilemma Cubans young and old have faced in these times, we'll see it is largely a polemic internal to socialism itself. It asks, what kind of socialist state, and socialist economy, do we want to build? In its deepest manifestation the contradiction of internal exile is one of disillusionment less with the core ideals of the Revolution, than with the Cuban state's repeated and often dreadful failures of imagination in carrying them to fruition. This, anyway, is what I discern in the views and actions of the entrepreneurs who populate this ethnography. They echo what the historian Lillian Guerra calls a "profound disorientation" felt in Cuba at the end of the Cold War, when the Revolution's grand narrative of national deliverance from imperialism, tenuous though it was, "still served as the common anchor of a society left adrift in rough political seas" (2012: 2).

Already what I have said about Carlito might seem to belie this claim about moral ambivalence. I would have to concede this point flat-out had I nothing to say about 
Carlito's everyday life, and that of others with whom he worked in the market, or that of the many others who made a living, like him, in the growing private sector in Havana, legally and illegally. It is principally for this reason - because of the need to appreciate at close range the everyday struggles of Cubans — that I have sought to write an ethnography of materiality, morality and power drawn from the microcosms of their lives. There will be much more to say about Carlito and his compatriots in the chapters to come. For now, may it suffice it to say that his disposition toward the pragmatics of life in the marketplace was not as negative as he sometimes made it out to be. Carlito's negativity, like that of many Cubans, is best understood as a cunning performance of disillusionment. This is not to say it was false, but that it caricatured life in the market and in Havana at large in such a way that could easily mislead a casual listener, especially one with certain preconceived notions or ideological inclinations — conveying the impression that everything was wrong and nothing was right.

More important, Carlito readily participated in and produced together with his fellow workers an ethos of gift exchange embedded in a market of invention, or, as I will call it, the invento market. This ethos, and the reciprocal relations on which it relied, pervaded work in Havana's private sector in spite of its characterization in official Communist Party language as a "necessary evil" contrary to the ideals of socialism, or by outsiders who are largely critical of the Revolution as the proverbial tip of the capitalist iceberg on a collision course with Cuban history.

The economic practices and political struggles prevalent in Cuba's invento market will be brought to light, therefore, through a neo-Maussian framework. Theoretically, 


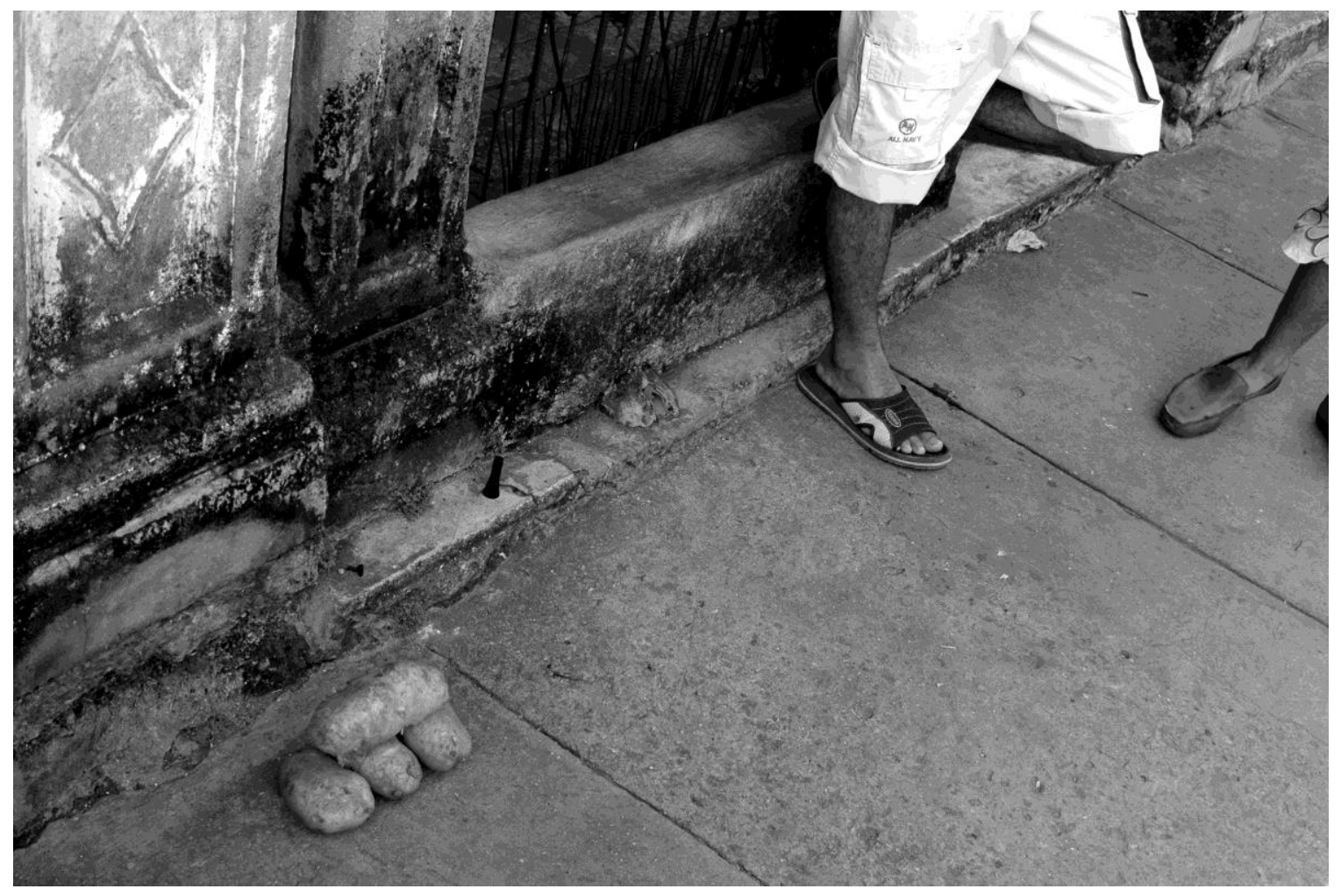

\section{PHOTOGRAPH 1.1}

Invento. Potatoes are usually rationed and can be hard to come by. Here, a group of men discretely offers a few potatoes for sale on a city street. Even this simple kind of economic activity often depends on dense networks of social relations and mutual support.

such a framework reasserts reciprocity as central in many domains of modern life, particularly subaltern ones. Politically, it tends to destabilize totalizing economic frameworks, and actual economic practices, which undermine the potential of reciprocity. As I will outline in my theoretical discussion, the anthropology of exchange has developed along two broad traditions, one that tends to analyze capitalism and capitalist markets as monolithic, hegemonic forces even as it critiques the effects of those forces on subaltern subjects, and another that laments this structural inequality but, all the same, tends to obviate it through a celebration of postmodern subjectivity. While I sympathize 
more with the trenchant critique of capitalism found in the first tradition, both are ultimately as unsatisfying as they are, in their own way, insightful. In gesturing toward a synthesis of these positions, and a reframing of political economy, this dissertation demonstrates how private-sector entrepreneurs, workers and consumers in urban Cuba coproduce an alternative market morality — and in the process a subaltern political praxis. I interpret the particular morality of their social universe as a form of competitive solidarity, because it strives to build collectivist relations through competitive, marketoriented practices. This interpretation calls for us to think beyond the stark theoretical contrast between economism and postmodernism, and to revisit the potentiality for markets themselves to produce a moral personhood that rejects the fundamental Western notion of the self-interested individual.

In developing this analysis, I pose three related questions. Namely: What does this market of invention in urban Cuba look like - what are its key moral characteristics, discourses, and behavioral dispositions? How did it come to be - what is its particular history? And what effects has this conception of a moral market had on meaningful social life? These are the answers I offer to each of these questions, in summary:

- The invento market in practice is anti-consumerist and anti-capitalistic. And insofar as the Cuban state is chief among the purveyors of capital accumulation and the desire for the acquisition of objects for their own sake, the invento market stands in opposition to the state's authoritative discourse - even as it draws on key symbols of the Revolution to justify and make sense of itself. These practices, 
furthermore, are embedded in, productive of, and realized through social relations that operate on intelligible, if unwritten and flexible, codes of reciprocity. As I have already suggested, this situation has something of the ethos of gift exchange, even though it operates in a market modality. The social relations inherent in Cuban inventiveness are not however overtly "political" — not, in any case, in the native sense of the term, which connotes public debates about power. On the other hand, they do have political consequences. Action in the invento market, legal or otherwise, cannot properly be called dissidence, and in the main its subjects make no pretensions to being dissidents or enacting "resistance" against the state.

- This social reality arose out of a particular historical complex, and for this reason a fair but focused amount of background will be needed to fully explain it. First of all, it emerged in a time of crisis and in response to prosaic matters of survival. The crisis came following a long process of social upheaval and transformation in Cuba that produced key discourses and ideological dispositions on which Cuban people could readily draw to construct and explain for themselves what they call invento. In this sense, it has been as much a product of state-level action as a response to power. To the extent that invento opposes, in practice, aspects of state socialism, they are those aspects in which the state appears as a distant, spectral and capricious agent of power and violence, and its discourse is therefore reworked in everyday action. This history is not without precedent; on the 
contrary, it is greatly informed by the literature on state socialism in Eastern Europe, especially work on the "second economy," or the informal sector.

- Cubans' everyday inventions have revealed themselves to be central to social change on the island. Practically everyone is enmeshed in the workings of invento. I make this claim in disagreement with the views of many analysts, both in Cuba and beyond, who downplay the importance of this social arena, maintaining that it remains a secondary, if significant, factor in the national economy. Indeed, its importance has only seemed to grow and, as recent changes suggest, it has had the effect of reconfiguring the national dialogue - much faster, it would seem, than standard U.S. discourses and American policy have themselves been able to shift accordingly. But even before these changes, that is, already during the time of my extended fieldwork, the playing field of everyday politics was in flux in ways that tacitly favored the expansion of the invento market. Saying so does not, again, foretell any particular "end" to this story, or a certain "transition," but it does have implications for a progressive conversation about Cuban-U.S. relations, which I address in the conclusion to this work.

Following a summary of recent history and the context of invento practices in late socialist Cuba, including a few key terms and some ethnographic background, much of the remainder of this introduction provides a theoretical overview of the ideas motivating my research. I also discuss some particulars of my methodology, including the ways in 
which my subject position in the field inflected those methods, as well as the analytical strategies I have used to interpret and write about what I saw. I conclude the introduction with a brief overview of how the rest of this work is organized.

\section{At a Crossroads: Cuba, and Cuban scholarship}

The emphasis on inventiveness in everyday praxis may be as old as Cuba itself.

Certainly, the history of the Cuban Revolution has created the conditions for its centrality in contemporary life, a point I take up in further detail in Chapter 2. For now, I wish to foreground how invento has emerged in the processes that have reconfigured Cuba's socialist economy since the collapse of the Soviet Union. Those trends, all interrelated, include the rapid expansion of the tourist sector, the state's reluctant opening of limited forms of private enterprise, and a marked increase in remittances from family overseas, now estimated at more than $\$ 2$ billion a year in cash alone - and more than $\$ 5$ billion counting in-kind remittances (Morales and Scarpaci 2013; Orozco and Hansing 2011; see Tables 1.1 and 1.2). The state's official discourse about these changes holds they have protected and preserved the Revolution and its social achievements. It has proved true that the one-party system has survived, first the Soviet collapse, and more recently the global economic crisis of 2008. And it may very well be true that socialist dispositions among the Cuban people have ultimately been strengthened in the process - but not necessarily for the reasons given in the dominant discourse. The invento market that has emerged in the course of an undoubted transition to state capitalism remains morally and politically dubious, a fact that deserves special attention. 
TABLE 1.1

Sources of Domestic Revenue in Cuba, 2012

\begin{tabular}{|c|c|c|}
\hline Rank & Source & $\begin{array}{l}\text { Amount (in } \\
\text { millions of } \\
\text { U.S. dollars) }\end{array}$ \\
\hline 1 & Tourism & $2,613.30$ \\
\hline 2 & In-cash remittances & $2,605.12$ \\
\hline 3 & In-kind remittances & $2,500.00$ \\
\hline 4 & Nickel exports & $1,413.00$ \\
\hline 5 & Pharmaceutical exports & 500.00 \\
\hline 6 & Sugar exports & 391.30 \\
\hline
\end{tabular}

Morales and Scarpaci (2013), based on statistics published by the Cuban National Office of Statistics and Information.

TABLE 1.2

Remittances to Cuba: Some Characteristics

\begin{tabular}{lrr}
\hline & 2005 & $2010-11$ \\
\hline From the U.S. & $81 \%$ & $68 \%$ \\
From Spain & $12 \%$ & $7 \%$ \\
Years receiving & 4 & 9 \\
Received per month & $\$ 150$ & $\$ 125$ \\
Frequency per year & 6 & 9 \\
From parents & 18 & 20 \\
From siblings & 22 & 35 \\
Received informally & 54 & 50 \\
\hline
\end{tabular}

Orozco and Hansing (2011), based on survey data. 
The year after the revolutionary victory, Fidel Castro spoke at a gathering of intellectuals who were concerned about the future of creative freedom in a rapidly transforming political context. He famously gave them this assurance: "Within the Revolution, everything; against the Revolution, nothing" (Castro 1961). The state would repeat this mantra in the mass media for decades, placing it at the very core of the authoritative discourse. It is not hard to imagine how such a dogma lends itself to a dizzying sense of openness and apprehension. The term "revolution" stands above even the project of socialism, and so becomes an empty vessel to fill with whatever meanings one is powerful enough to project. Staying within those meanings, respecting the power from which they issue, allows the subject to experience freedom of thought, creed, expression and association. Stray beyond the meanings currently in vogue, and you might find yourself "outside the revolution," a pariah.

As a way of representing the polemical nature of this discourse, in this work I will refer to the Revolution in its institutionalized, bureaucratized form as a proper noun (capitalized), which also follows the predominant native convention. In a similar way, I will sometimes refer — as Cubans do — to Fidel Castro only by his first name. In doing so, I am not adopting a particular side in the long-lived family feud that is Cuban politics. Rather, I mean to invoke in these usages the sense of familiarity and intimacy, very real if at times tortured, that most Cubans feel toward Castro as person and as national symbol. It is through the image of Fidel that the dogma of the Revolution flows: the discourse that at any given moment determines what is in and what is out. 
The practical consequences of this dogma can be seen in the changing whims of official policy. Ideas about sexuality and race under the Revolution are instructive in this regard. Homosexuality, once treated as a plague contrary to the Revolution's masculinist ideal of the New Man, is now openly discussed and tolerated, even as machismo and homophobia remain entrenched in national discourses on health and HIV/AIDS (Leiner 1994; cf. Reed 2012). Prostitution, widespread in the Batista era, in the 1960s and 1970s was scorned and stringently prosecuted. But now sex tourism in Cuba has reemerged as a prominent feature of life on the streets of Havana and other major cities (Rundle 2001). Racism was said to have been eradicated under the Revolution with the stroke of a pen, but such edicts in fact discouraged any open discussion of racial disparity, this despite the continued distribution of poverty and power along racial lines. And yet today a serious discussion of race in Cuba seems to be taking place once again (Pérez-Sarduy and Stubbs 2000). In a similar fashion, the economic meanings of "revolution" and their implication for productive activities have always been in flux. Many entrepreneurial endeavors once deemed counter-revolutionary are now carried on in full public view rather than in private: Handymen repair watches on the sidewalk for a few pesos. Old men resell their rationed matches. Old women sell homemade pastries. Children peddle original art. And hustlers jockey for the attention of sightseers.

To fully understand how these developments came to be, it will help to recall something of Cuba's social history. Because I elaborate on this history in Chapter 2, here I provide only a brief sketch. 
Cuba gained only nominal political independence from Spain at the end of the nineteenth century. The government in this republican period remained a virtual protectorate of the United States. U.S. interests retained political and economic influence over Cuba by dominating the island's sugar industry. This influence was periodically exercised through overt military action justified under the Platt Amendment, a clause in the Cuban constitution giving American presidents the privilege of intervening in domestic affairs "for the preservation of Cuban independence." The Cuban republic in all its permutations failed to reverse widespread poverty, racism and inequality left in the wake of four hundred years of colonial exploitation (Fuente 2001; Helg 1995; Pérez 1999). Revolutionary forces ultimately capitalized on the widespread disillusionment of the Cuban people, and at the close of 1959 the rebel army under the lawyer-turnedrevolutionary Fidel Castro, eldest son of an eastern plantation owner, seized control of the government following the exile of military strongman Fulgencio Batista. Fidel and his followers promised radical social reforms to the tens of thousands of Cubans who rejoiced in the street. Almost immediately, the ad hoc revolutionary government delivered on promises of agrarian reform, wealth redistribution, and progressive education and health policies. But many thousands defected when, in the early 1960s, it became clear the changes would include a one-party Marxist-Leninist political system aligned with the Soviet Union (Fagen 1969). For the overwhelming majority of Cubans who stayed behind, this euphoric era of transformation brought with it real excitement and social engagement, for example, in the form of the Literacy Brigades organized to 
teach poor rural people to read and in housing programs intended to eradicate homelessness and underdevelopment.

Official discourse about the Cuban revolution since this time has been articulated in terms of a perennial struggle against capitalist institutions in general and U.S. interference in particular (Dalton 1993). But the revolution was itself institutionalized in the 1970s in the form of the socialist-bureaucratic state, subject to the interests of yet another world power (Pérez-Stable 1993). Political happenstance thrust the Soviet Union into the position of Cuba's main ally and trading partner, and the socialist bloc in Eastern Europe heavily subsidized the Cuban economy for decades. With the dissolution of the U.S.S.R. in 1991, the Cuban government averted a total economic collapse with a new political economy involving limited market reforms (Moreno 1998). This is what Castro identified as "a special period in peacetime."

During this era, what Pérez-Stable (1999) has identified as Cuba's "radical nationalism," expressed in official socialist terms, has not faded from view. If anything it has effloresced. By every indication, state institutions - in the tourist sector, biomedical research and development, and the export of luxury goods, such as tobacco and gourmet coffee, as well as intellectual capital, in the form of highly skilled workers - have become the primary agents of capital accumulation: for the good of the Revolution and the nation, it is said. This perspective in practice has been translated into incentives for foreign investment and tourism, transforming national treasurers like Havana's old-city district into premier UN World Heritage sites while also displacing poor residents or 
putting them at risk by diverting building investments from renovations in areas where they are much needed (see Hill 2004).

It also accompanied the legalization of the U.S. dollar and, more recently, the requirement that dollars and other foreign notes be traded for a secondary Cuban currency, known officially as the convertible peso (CUC). This is Cuba's divisa, or hard currency. Accepted nowhere else in the world, these instruments were introduced to ensure that the state could earn commissions on dollar exchanges. The resulting "dual economy" - with some exchanges happening in pesos, others in divisas, and still others possibly in both - mirrors literally and metaphorically the increased stratification of Cuban society, patterning roughly with one's relative access to foreign cash. It says something of the peculiarity of this situation that there is no shortage of slang terms for convertible pesos: including fula and chavitos (after, it is said, the late Venezuelan president Hugo Chávez, who came to Cuba's aid with oil subsidies); they are also, confusingly, called pesos, just like the official currency (CUP), referred to as the moneda nacional to distinguish it from its divisa counterpart. In many ways the problem of how to resolver (a ubiquitous colloquial term for "solving problems in creative ways," i.e., getting by on a daily basis) is most pronounced among those least connected to the divisa economy — that is, most Cubans. With only marginal links to tourism and remissions, these people are faced with the practical and ideological problem of plugging into a changing socioeconomic system one way or another. As their language suggests, they must find a way to solve this problem through entrepreneurship in their everyday lives in 
complex ways. And, as we shall see, they've adapted socialist discourses and ideas about la lucha ("the struggle") to justify and explain the invento market.

Cuba is a Caribbean island. This hardly seems worth mentioning, and yet it is a fact often ignored in contextualizing Cuban history and society. The relationship between the public and the private, and the performativity of political power, has long been a focal point of Caribbean ethnography, with special emphases on expressive culture and West African influences (e.g., Abrahams 1983; Glissant 1989). Such essentializing discourse is not without its critics. Among the most recent and subtle is Antonio Benítez-Rojo's meditation on the historiography, literature and scholarship in the Antilles. Although Benítez-Rojo (1996) risks reproducing the very object of his critique, he offers a valuable warning to social scientists against reading their own meanings and categories into a Caribbean worldview. He imagines this worldview to be a "soup of signs" founded on the region's plantation and colonial past. Ethnographers have often drawn on a related concept borrowed from linguistics, "creolization," to interpret this cultural soup (e.g., Brathwaite 1974; Drummond 1980; cf. Ortiz 1940, which used "transculturation" and ajiaco, "Cuban stew," in a similar manner). Although no more hybrid than anywhere else in the world, these works as a whole suggest that the Caribbean in particular needs to be seen as inheriting a cultural lexicon from Europe reworked in a grammar largely descended from elsewhere, especially West Africa. In everyday life the awareness of this mixture results in a kind of massive identity crisis, making national formation in the context of a world already carved into nation-states an inescapable problem for societies across the Antilles. Perhaps Hall (1995) puts it best in suggesting that identity struggles 


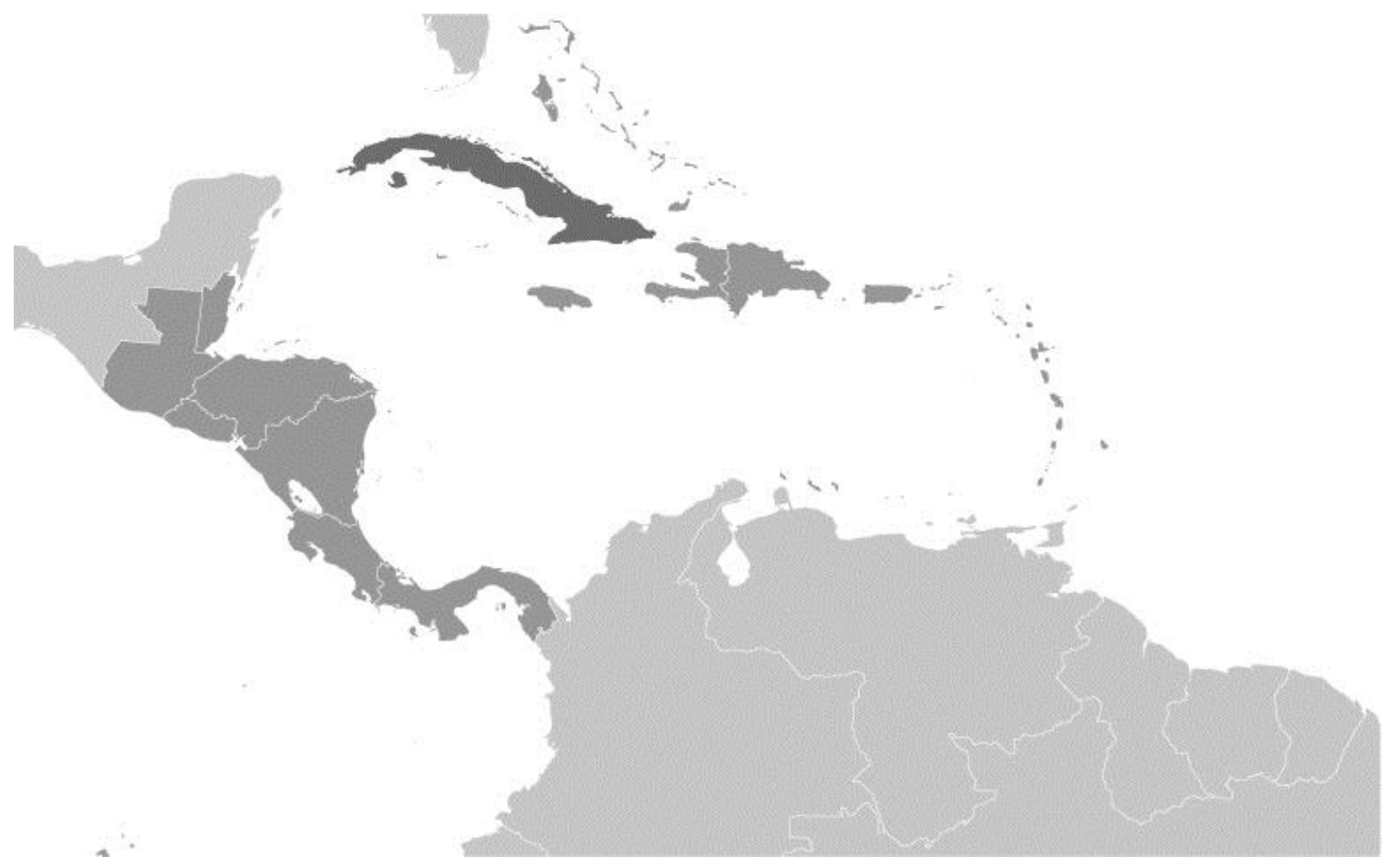

\section{MAP 1.1}

Cuba, Key to the New World

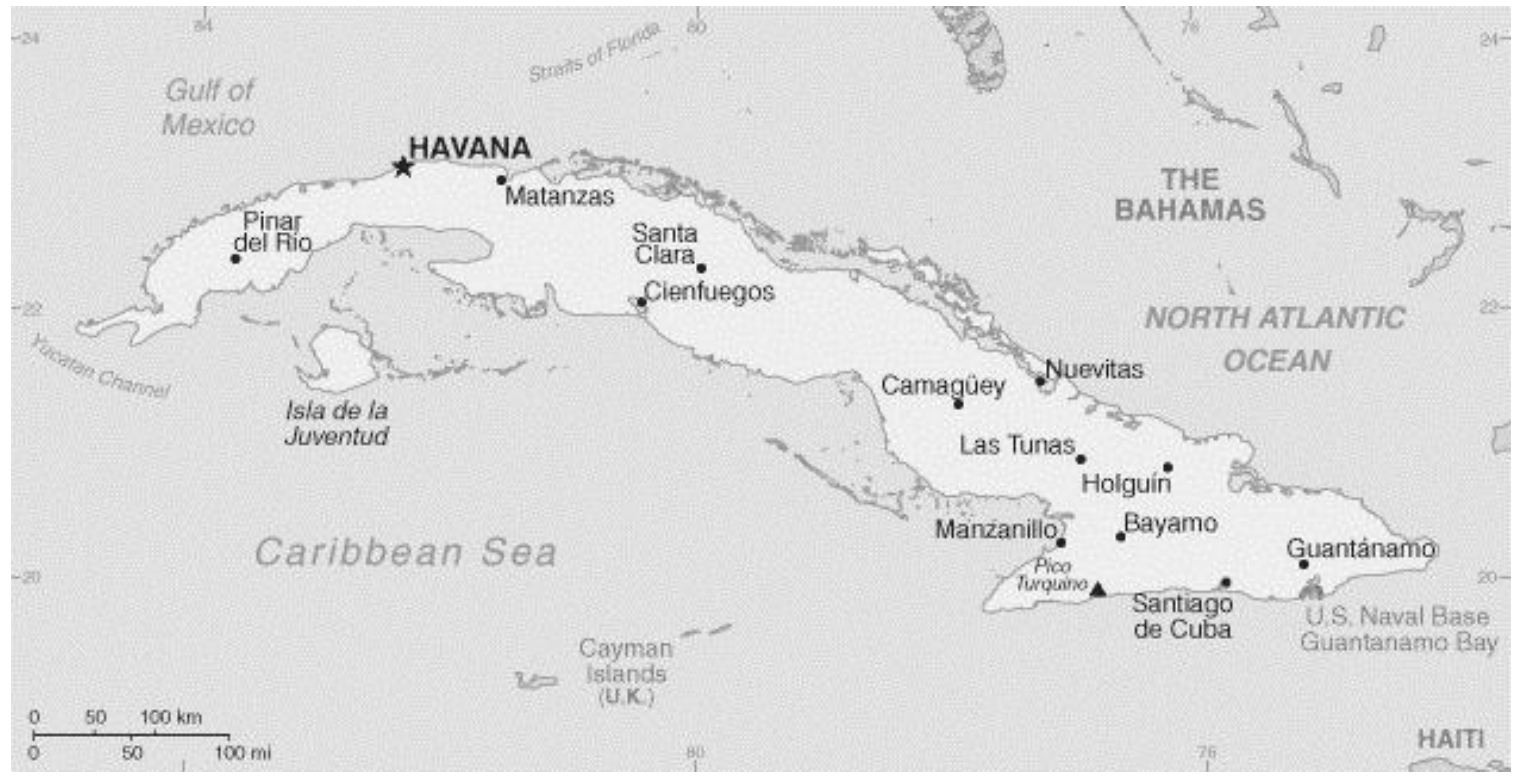

MAP 1.2

Cuba: Major Cities 
in the Caribbean are neither apolitical nor fancifully postmodern but critical to getting by on limited material resources. Hall calls this situation the "purest diaspora," since local traditions lack the power to mask their own inventedness; in the Caribbean, one's identity — regardless of race — is never taken for granted.

Others have noted the problematic of nationalism in the Caribbean (e.g., Mintz 1974), and Cuba is no exception to this phenomenon. Building on recent scholarship examining nationalism in the island's racial discourse (Ayorinde 2004; Bronfman 2004; Moore 2006; Rodríguez-Mangual 2004), my master's project addressed the thorny relationship between the social science of Fernando Ortiz, Cuba's "native father" of ethnology, and his nationalistic, anti-imperialistic aims (Armengol 2005; cf. Ortiz 1940, 1973). Though he began his career as a champion of scientific racism, Ortiz became one of its foremost detractors, and in his political life he struggled to chart a new path for Cuba as a "mulatto nation." Still, he did not escape, and indeed promoted in his construction of Cuba the kind of radical nationalism on which the revolution of the 1950 s would later be premised.

The issue of cultural identity in Caribbean power struggles is complicated further by the commonplace yet profound ambivalence among its natives about belonging, staying and going. The modern history of Cuba and its sea-bound neighbors, you might say, is a history of exile and repatriation. More than a bit of recent ethnography has focused on the importance of transnational social systems rooted in and linked to the Caribbean (Brennan 2004; Duany 2000; Freeman 2000; Richman 2005). But while it cannot be denied that ever more intense global forces are reshaping life for many people of the region, it must also not be forgotten that, predating European colonization, the Antilles 
provided a geographical crossroads of many and distant ties. This was no less true in the centuries following Christopher Columbus's westward voyages. In what is now a classic treatise on the cross-Atlantic sugar trade, Mintz (1985) demonstrates how the plantation islands of the Caribbean provided the structural and, indeed, nutritional engine of Western capitalism in the 1800 s.

Like its island neighbors, Cuba today no longer depends on a sugar monocrop. Instead, it is the production of bodies for the international labor market, along with the importation of bodies to fuel the tourist economy, that dominate the making of meaning and social structure. There is no lack of scholarship on Cuban transnational migration (see Fernández 2005), though in many regards it misses the parallels to be made with transnational processes elsewhere in the world, focusing instead on the standard nationalist narrative of exile and diaspora. For this reason, I think, juxtaposing urban farmers markets and entrepreneurial activities against the state's present entanglement with global capital is more than justified.

In any case, a transnational perspective would not in itself necessarily provide answers to the question of the effect everyday praxis has on the political economy of Cuba, or to political-economic theory in the abstract. To focus too much on transnational relations risks, for one, reifying national boundaries, and, furthermore, underestimates the extent to which these relations are always grasped through local systems of categorization (cf. Sahlins 1985). Rosendahl (1997) predicts, based on ethnographic work in Cuba just before the Special Period, that sociopolitical change on the island will need to be understood through the dynamics of "informal exchange" as it has evolved domestically. 
Social theorists in other disciplines (Centeno and Portes 2006; Centeno 2004; Fernández 2000; Pérez-López 1995) see the evolution in Cuba of what they call the "second economy" or the "informal survival network" and connect it to historical processes that have produced political instability and disaffection across Latin America. They argue, correctly, that informal exchange in Cuba has become essential to daily life, casting doubt in the process on the state's claim to centrality and dominance. These same theorists speculate - prematurely, it seems to me - that the phenomenon of the secondeconomy-turned-primary signals the "end stages" of a transition from socialist to capitalist development. In fact, my findings suggest, these networks reflect a public if not vocal resistance to transition, casting the whole edifice of transitology into doubt. To wit, the concept of "transition" already has proved problematic for an understanding of socialism and postsocialism in Eastern Europe, for reasons I shall address in the following section.

Against the bureaucratic and political odds, meanwhile, a new generation of anthropologists has been producing ethnographies of things Cuban that, at least implicitly, challenge the development perspective and provide useful guides for my own work. Blum (2011) shows how ideological icons like Che Guevara are reinterpreted among schoolchildren in formulating their relationship to official state doctrine, giving socialist values meaning "on their own terms" in order to deal with the pragmatic difficulties they envision on their personal horizons. Cultural dynamics like those Blum identifies are hardly unique to Cuba's primary education system, and it is clear they operate in rural as well as urban settings. Eastman (2009) considers how baseball in 
Havana, as grand symbol and everyday practice, opens spaces for refiguring the Cuban nation-state and Cuba's political economy. And in her analysis of rural theater groups, Frederik (2012) argues that performative genres emphasizing authenticity and purity in the anti-imperialist struggle against globalization, intended to invigorate allegiance to official socialism during the Special Period, led inadvertently to the commercializing of such images. These and other recent works (e.g., Premat 2012; Weinreb 2009) suggest not only that the nexus between market activity and authoritative discourses in Cuba needs to be more carefully studied. They also suggest that the time has come for exploring this nexus in earnest as a political struggle, over the meanings and purpose of both Cuban socialism and the nation itself. I turn now to the development of an effective theoretical framework through which to carry out that exploration.

\section{Economic Anthropology: Gifts, Reciprocity and the Market}

The problem of formal economic theory is not so much that it is wrong, but that it is right only for a certain finite expanse of human time and space, applicable only within the logic of that system, and on its behalf, and even then only to the extent that the lived reality of the system increasingly approaches the logic of the ideal type, which anyway is always still less than economists presume. Indeed, as Gregory (1997) suggests, much of neoclassical economics serves to reproduce and intensify the very "free market anarchism" that, it purports, is a natural outgrowth of the human condition. Carrier and Miller (1998) use the term "virtualism" to refer to the self-fulfilling and self-justifying designs of what we might call the neoliberal practico-theoretical complex, enacted in the 
name of the consumers it in fact constructs. Graeber (2001: 7) underlines this point in reminding us that economic models are developed mainly to make accurate predictions about "the economy" that are useful to the major financial players who most benefit from the system.

And yet, while it is all but axiomatic for anthropologists to assert that, of course, the production and consumption of material goods is always culturally embedded, one might legitimately question the value of a new economic anthropology, given the dominant historical trajectories of the field (Merlan 2009). The relativizing, integrative perspective has been fundamental to anthropology's take on economic life since the pioneering work of Malinowski, Mauss and Polanyi. But this thrust has developed over the years into what Robotham (2005) has called a "rejection of 'economism.' " Austin-Broos (2009) identifies this as a tendency toward scholarship that reduces the satisfactions of material ends, their forms, and the meanings attached to them, to strictly noneconomic explanations rooted in other domains: ritual practice, symbolic play and the maintenance of social structure, for example.

On one hand, then, analyses of economic practice are marginalized from the mainstream literature or become precisely the subject of critique, as when ethnographers position themselves explicitly against "what economists do." Not without cause, economism is characterized with derision as reproducing the commodity fetish and the related Western ideal of the maximizing, self-interested individual. On the other hand, where deep economic disparities are concerned, whether at the global or local levels, culturalist accounts of economic activity tend toward a romanticized view of alterity. In 
such accounts (e.g., Scott 1985), peasants or the urban poor or the working classes are portrayed as stubbornly surviving, resisting and undermining the economic modes that dominate their lives and livelihoods. While these approaches have yielded more than a few moving stories of real lives, as well as much in the way of understanding things economic through a cultural lens, they avoid dealing fully with the real effects of global capitalist expansion. This presents a challenge to the present generation of scholars. We should ask whether we have given up too much to the neoclassical economists; and whether as a result anthropology has made itself irrelevant in wider debates that shape commonsense notions of the economy and influence decisions on economic policy. Addressing this challenge is a major aspect of this dissertation. I contend that marketoriented invention in late socialist Cuba has something to offer to a debate that has largely focused on other parts of the world and, of course, on capitalist markets.

Anthropology's early attempts to grapple with economics came as a reply to the classical work of Adam Smith and his contemporaries. Smith (1776) regarded the propensity to "truck and barter" as one of man's vital instincts. It was with him that political economy was born and so too the presumption that capitalism and its growing monetary framework reflected the highest institutionalization of trade. The response of anthropologists considering primitive exchange in the early to mid-twentieth century, from Malinowski (1922) onward through Sahlins (1972) was to question the notion that barter, accumulation and competition were natural drives. As Gregory (2009) writes, "The keyword of this paradigm was reciprocity and the theories these scholars developed were variations on the general theme of exchange" (2009: 287; emphasis in original). 
Their ethnographic data, meanwhile, served mainly to tear down Smith's "natural economy," rendering familiar the elaborate exchange of gifts — from armshells to wives — as the nexus of social relations.

Gregory suggests that in the 1970s, the buzzwords became "production" and “articulation.” Studies such as his own $(1982,1997)$ represented reactions, tacitly and overtly, to the Vietnam War, neoliberal policies and Nixon's dismantling of the gold standard. The resulting development of underdevelopment unleashed in anthropology what Gregory calls a "Marxist-inspired conceptual framework" (2009: 288). This framework privileged production rather than exchange in an effort to address a problem previously noted but mainly ignored: the effects of European conquest and the new imperialism that was now its heir. Articulation as such referred to the many devastating local realizations of the capitalist project. Gregory flatly asserts, however, that the neoMarxist framework was "over before it started" (ibid). With the retreat from Saigon and the advance of postmodern thought across the humanities, the anthropology of economics turned gradually toward a fascination — perversely indulgent, at times — with "consumption" and "agency" as the paradigmatic concepts du jour. Identifying this move with such groundbreaking scholars as Ortner and Douglas, Appadurai and Wagner, Gregory allows that they afforded power to the indigenous and the subaltern by proving such peoples with all their symbolic, material and institutional creativity to be effective guardians of their own human value, more than mere victims of capital. At the same time, he laments how the consumption-and-agency scholarship gradually turned the labor theory of value on its head. This has happened, paradoxically, in an era in which massive 
amounts of wealth can now be transmitted with stunning electronic efficiency from the backs of undervalued workers around the world to the pockets of investors and executives on Wall Street.

This does not however preclude the existence of theoretical alternatives existing alongside the present dominant paradigm. Gregory suggests that work on socialism and postsocialism in Eastern Europe, along with studies on "failed" postcolonial states, informal economies, transnationalism, and the "financialization" of the global economy, will help push the subdiscipline into a new era, if it can first avoid carving itself up into disparate regional specializations with "discourses that share little in common" (2009: 292). The commonality Gregory finds most compelling is "distribution." In some way or another each of these topics deals with the movement and ordering of people, things and values. None of this work overthrows Polanyi's substantivist thinking on the economy as a culturally embedded process. But new contexts do require ethnographers working in economic settings to rethink the relevant "substantive features," or, to put it another way, how material life is "performed differently" in the Internet age (Gregory 2009: 295; McKay 2009). The old conceptual distinction between commodities and gifts is anything but obsolete in this sense. Gregory concludes, rather, that we must view these competing systems of value as coexisting in tension with each other.

In the introduction to an exceptional edited volume, Money and the Morality of Exchange, Parry and Bloch (1989a) argue along similar lines that much earlier work employing the notion of gift as opposed to market exchange entails a typological boundary between cultures, while in their view what the dichotomy best clarifies is a 
general contrast found within many cultures. In their formulation, gift exchange corresponds to the overarching, long-term cycle of social reproduction, and market exchange to the more limited, short-term order of personal reproduction. Hence they offer one possible critique of capitalism on this basis: "By a remarkable conceptual revolution what has uniquely happened in capitalist ideology, the argument would run, is that the values of the short-term order have become elaborated into a theory of long-term reproduction" (Parry and Bloch 1989b: 29). But the authors go on to point out a second possibility, one inspired by Mauss and, perhaps, more easily rectified: that Western ideology has produced a "radical divorce" between the two cycles such that it is "unable to imagine the mechanisms by which they are linked" (1989b: 30).

What we need then is to recognize the importance, even perhaps the centrality, of relations of reciprocity, without however exoticizing gift exchange as an exclusively archaic practice, or looking for it with a mechanistic, primitivistic frame of reference. By the same token, we should complicate our concept of "the market," which is too tainted with orthodox economism. A better and more anthropologically tenable understanding of markets would treat them as both physical and conceptual sites enabling the exchange of more or less equivalent values in a range of modalities.

Such an understanding calls for reformulating the useful but somewhat problematic appreciation of market economics found in the classic work of Bohannan and Dalton (1965 [1962]). Their introduction to the edited volume Markets in Africa sets up a sharp distinction between "the market" as a principle of economic organization and “marketplaces” (or simply "markets") as geographical sites where buyers and sellers 
trade in goods of equivalent value. Bohannan and Dalton take the principle on which the market in the abstract operates to be given in the standard assumptions of classical economics, namely that prices are determined by the pressures of supply and demand and that rational choices lead participants in market transactions to make decisions about production and resource allocation that are guided strictly by the profit motive. Marketplaces, by contrast, are understood as concrete social arenas in which the market principle may operate to a greater or lesser degree and in which "non-market" values grounded in moral propositions — be they political, social or religious - might just as well prevail over the profit motive. For example, prices in a given marketplace may be established on the basis of local supply-and-demand pressures and yet, at the same time, have little or no effect on the decisions producers make about what to produce or when and how to market it; this will occur in cases where decisions about production respond mainly to non-market principles. On the basis of this distinction, the authors identify a threefold typology of market modalities (Table 1.3), corresponding to the various case studies presented in their volume.

These modal types depend, first of all, on whether the market principle tends to be dominant and, on the other hand, whether marketplaces themselves are more or less present. In the most basic societies analyzed, both the market principle and marketplaces are generally absent - briefly stated, this is what anthropology has historically regarded as "traditional" social organization. A hybrid situation occurs where markets have been established but in which the market principle has not significantly penetrated traditional social norms. Finally, in the archetypal modern or modernizing society, markets and the 
TABLE 1.3

Marketplaces and Market Principle

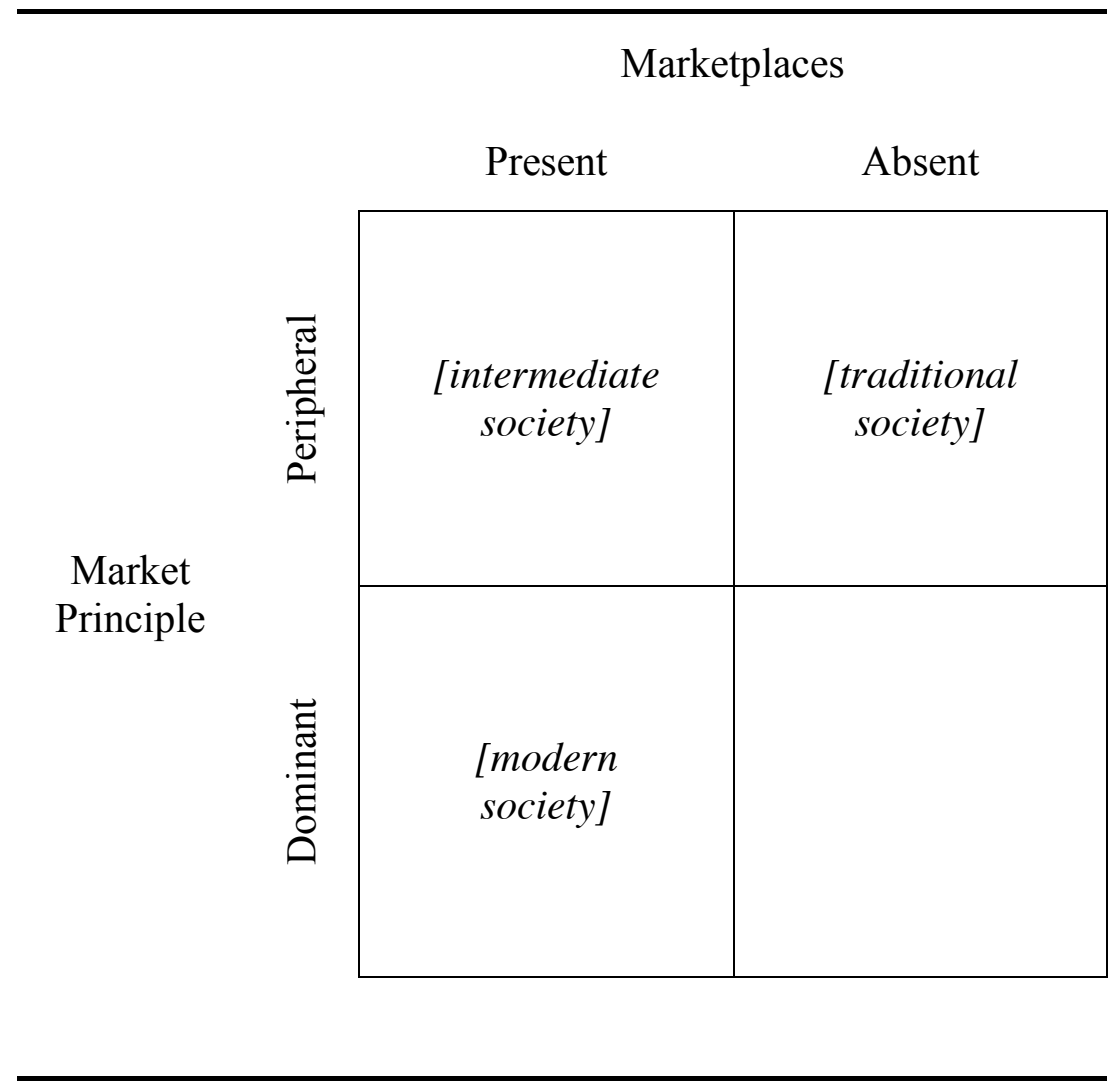

Synthesis of Bohannan and Dalton (1965: 3).

market mechanism are equally prevalent and work therefore in concert. (A fourth theoretical possibility is excluded from this typology, on the acceptable logic that physical marketplaces are never absent where the abstract market principle has come to dominate exchange practices.)

While this typology helpfully complicates the dichotomy between traditional and modern society, it ultimately reproduces a teleology of Western economic logic by failing to recognize the way in which all market-oriented contexts are culturally inflected. This 
problem is recognizable in the flat assertion that, following Evans-Pritchard (1954), Bohannan and Dalton make with regard to so-called marketless communities: "The important feature of such communities is that they have no economy that can be analyzed apart from social organization" (1965: 1). Admittedly, this perspective represented an advancement in socioeconomic theory in that it attempted to clarify for economists those economic behaviors that might seem "bizarre" with respect to a neoclassical framework. It should not surprise us in the least that marketless societies "have no economy that can be analyzed apart from social organization." The issue, as I see it, is rather that no society has an economy that can be so analyzed. There is in other words no objective market principle existing as such, waiting for primitive man to discover it. The market principle is itself a culturally constructed characteristic of capitalist social organization. To the extent that it has penetrated in Africa or anywhere else, this is largely because of the historical circumstances of colonialism that Bohannan and Dalton address later in their essay - apparently without recognizing the paradox into which they have stumbled.

The reluctance to fully recognize this paradox has much to do with the authors' intended project. They are speaking explicitly both to economic anthropology and to the question of economic development, and they are trying to reconcile the two. But this development-oriented perspective associates "backward technology and traditional culture" with the failure of strong state integration (1965: 12) and implies that any resistance to change should be understood as a problem of archaic communities somehow failing to see the light of the market. This is evident in the authors' discussion of the subsistence-oriented Lele people of central Africa, as contrasted with such societies as 
the Nilotic Kipsigis, who are all but lauded for their extraordinary "eagerness to produce for sale" (1965: 27; 28-30).

I should note in passing that the inclination to view indigenous market practices as a problem to be solved with respect to the paradigm of rational choice is hardly unique to Bohannan and Dalton's analysis. For example, Brookfield (1969) brings together a series of insightful and detailed analyses of fledgling marketplaces in the Pacific islands, but in summarizing them he persistently looks for an explanation as to why certain markets fall short of the economic ideal given by the market principle in the abstract. Produce vendors across the region exhibited such perplexing tendencies as the "absence of competition, passive waiting for a sale, reluctance to reduce prices late in the day, the practice of each seller offering her own produce, refusal to haggle" (Brookfield 1969: 18-19). Though he concludes that standard economic theories will not suffice in understanding the Pacific context, the standard as such remains in place. And while Brookfield does not explicitly tie the "problem" of indigenous rationality to the problem of development, the implication is palpable in the concluding essay of the volume. Against this poorly veiled Western-centric perspective, however, critical postcolonial research more properly locates the consistent formation of weak states along with the slow pace of economic development across the global south as products of capitalist neoliberal expansion itself — what Frank (1966) has called the development of underdevelopment.

This is not to say that Bohannan and Dalton's influential analysis lacks merit. On the contrary, thanks in large measure to its internal tensions, it highlights certain useful contrasts and theoretical approaches, and these endure in spite of the structural-functional 
assumptions on which they rest. The authors recognize that "conversions" frequently occur between economic spheres, as when prestige goods associated with reciprocal exchange relations may be converted "downward" into monetary transactions associated with the market principle, or vice-versa. As they point out, such practices are generally evaluated on the basis of whether they are morally acceptable, not whether they are "skillful or unskillful" (1965: 8). This notion of conversion carries with it by implication the suggestion that we should attend to the ways in which gift exchange occurs within markets, and why that might be. The essay goes still further than this, indeed, in advocating an ethnography of markets that attends to their "non-market aspects." These include the fact that marketplaces provide sites for sharing information, gossiping, building social relations, policing religious customs, entertaining one another, finding love, and - perhaps most important to my own work — negotiating political power (1965: 18-24). My point here is that this sort of ethnographic investment should not begin and end with non-Western societies, as if (say) Christmas shopping at the local mall in an American city had none of these extra-market entanglements.

And what of that threefold typology? As there is no such thing as the market principle, objectively speaking, there can only be marketplaces, that is, there are only markets. At the same time, a cultural orientation toward the market principle as a feature of the modernist ideology of capitalism has real effects on the character of particular markets. In this sense, something like the typology that Bohannan and Dalton have proposed can be salvaged, if we reformulate these divisions as, first of all, fluid, and, more important, characteristic of particular economic spheres and practices rather than 
particular peoples. As with other misconstrued typologies in the history of anthropological theory, if they represent anything they represent types of human action, not types of society.

We should therefore not discount the extent to which the yearning for reciprocity and mutual obligation exists within markets. This then would be the starting point for a neoMaussian perspective. As I have argued elsewhere (Armengol 2012), Mauss suggests in the final chapter of The Gift that future ethnographic studies, as well as a future political praxis, would do well to invest in gift relations and learn from the "obscure aspects" of modern social life. Happily, anthropologists, sociologists and intellectual historians have of late been putting the pieces of Mauss's popular and scholarly work back together (Garces and Jones 2009; Graeber 2001; Hart 2007; Liebersohn 2011; Mallard 2011; Schrift 1997; Sigaud 2003). Collectively these rereadings suggest that the time has come to take seriously Mauss's notion of "economic movement from below” (quoted in Hart 2007: 478). Doing so has the potential to spark a concerted and publicly engaged focus in anthropology on subaltern exchange practices and solidarity movements within modern capitalist — and indeed, socialist — contexts.

In tracing her own history of economic thought in anthropology, Austin-Broos (2009) rejects even more vehemently the discourse of agency, arguing that local communities have never been so connected in one sense and disconnected in another. They are "connected" insofar as their productive lives and opportunities for well-being are linked to one another and to the workings of international trade ever more deeply. They are "disconnected" in the sense that indigenous peoples today have less power than ever to 
shape, on their own terms, the productive choices available to them - what they can do for a living and how they can do it (Austin-Broos 2009: 303). To her mind the facts on the ground can no longer support theoretical positions that, following Sahlins (1976) and Taylor (2004), simply dispense with the historical constitution of bourgeois ideology as a culture that fetishizes "practical reason," or "economy" as its own "objectified reality." To say this, as I read Austin-Broos, is not to say that these positions aren't valid, but that they are not especially productive. These do not represent an end point for the cultural analysis of modern economic life but a point of departure for an economic anthropology that comes to grips at last with the real effects of capitalist practice and ideology:

Capitalism, with its markets and its productive power, cannot specify local experience. It does, however, both expand and delimit possibilities; the range of symbols and media in which people render their experience. In sum, economies bracket possibilities without determining the human response. [...] Economy is causal and encultured. (Austin-Broos 2009: 307; emphasis in original)

It is not always or even often that local symbols encompass the capitalist project and turn it to its own ends; rather, it is through the changing structure of local symbols that the effects of capitalism are made intelligible. In other words, Austin-Broos contends, we need not adopt a teleological narrative of global economic history while attending, as we should, to its historical direction.

Anthropologists would also do well to recognize the history of their own theoretical trends as well, with a focus on regaining what ground has been lost to cultural studies. Looking back suggests a way forward through the logjam of substantivist vs. formalist 
perspectives. Where Gregory sees the twin paradigm of reciprocity and exchange dominating the subdiscipline's early literature, Austin-Broos attends to some finergrained distinctions. She points out that Malinowski's explanation of the Kula Ring privileged formalist notions of economic man, ultimately suggesting that the savages were rational too and therefore not so far beyond our ken. By contrast, Mauss recognized in gift societies a fundamental logic of social wealth and relationality that was radically opposed to Western thought and practice. This "cultural holism" was largely squeezed out of Malinowski's structural-functionalism. Polanyi (1957) elaborated Mauss's position in establishing the substantivist school, directly at odds with detached accounts of rational individuals whose intellects were, like everyone's, determined by evolutionary forces. But if vulgar Marxism had its telos in the dictatorship of the proletariat, so did Polanyi have a utopian vision for the collapse of finance capitalism and the re-embedding of the economy in sociocultural life. He neglected what Weber and, later, Wallerstein recognized all too well: the sustaining role of bureaucracy and the nation-state in the service of the world-system (Austin-Broos 2009: 304). So strong are these modernist paradigms, I will show, that they have dominated not only capitalist but socialist states, which could not escape their logic.

The 1970s also marks a turning point in the sense that the theoretical contest over economics in anthropology reached an impasse. The debate was not so much broken as sidestepped. Levi-Strauss urged a distancing from material questions in favor of the cognitive unity of man, and Bourdieu (1977) followed up this move by locating the production of cognitive categories in the "structuring structures" of everyday life. French 
structuralism repackaged at the hands of American ethnographers schooled in Boasian particularism produced an understanding of social life as text (Geertz 1973) and historical conjunctures as culturally structured (Sahlins 1985). The rest, as they say, is history. These developments were and remain, in my view, necessary bulwarks against the songand-dance of functionalism and technological determinism, but Austin-Broos does anthropological theory an important service in insisting that the baby was thrown out with the bathwater: "With them went the economy as well" (2009: 305).

Where does this leave us, where does it lead us? Robotham (2005) argues that the "hybridity" and "cosmopolitanism" so lauded in certain ethnographic accounts of late are never a matter of pure choice. They are propelled upon social actors in hegemonic contexts where the possibilities of rejecting the products of capitalism are simply not feasible. Fieldwork that would adequately address such complexities must by extension deal with "the types of subject, and their milieux, that we actually face" (Austin-Broos 2009: 308). Here Austin-Broos draws on Heidegger (1962) and Appadurai (1986) for inspiration, stressing that to interpret how subjects deal with the modern economic realities they face means interpreting how their material lives are realized in everyday acts (i.e., Heidegger's "concernful dealings") and how these in turn invest what Appadurai refers to as "regimes of value" in the objects and actions they experience. The strategies social actors employ to manage these values necessarily suffer repeated change as new objects and phenomena appear on the landscape. "Heidegger is appealing," she writes, "because he lays the ground for interpreting environments, social and material, as regimes of value constituted through changing institutional forms" (2009: 308). 
Positioned this way, fieldwork looking at economic phenomena would take seriously human political and moral struggles, assessing both the material and social-psychological toll those struggles exact. In a study as concise as it is suggestive, Gell (1982) has analyzed a weekly market in a village of North Bastar in central India for its symbolic as well as economic significance. The marketplace, he argues, provides a geographical mapping of social relations, especially the hierarchical relations between Hindus and Tribal peoples of the area. The village market of Dhorai is organized in a series of concentric rings characterized by higher-value goods in the middle, with goods of lesser value arrayed outwardly, reflecting also the relative importance of sellers and buyers who move through these rings and have access to them. Along the circumference of any given sphere, Gell demonstrates, geographical inter-village relations are further expressed among Tribals of roughly equal standing. Taking a tour of the market, he writes, is like taking a tour at once of the local area surrounding Dhorai as well as local conceptions of status and power. In this way, the market is more than an economic sphere in which people trade such seemingly inconsequential goods as cheap jewelry and cigarettes. It is also decidedly ceremonial; in its own way it communicates a social order that is otherwise "out of sight" in the daily life of the village, which tends to be egalitarian and homogeneous with respect to caste and ethnicity. Gell might have truncated his analysis at this point, having made a perfectly reasonable structural argument. The larger claim of the study, however, turns out to be that despite this socio-spatial mapping - actually, because of it - Tribal peoples in effect are able to exchange, via the market, their lower 
status for actual cultural and economic security against their Hindu counterparts and the Hindu-controlled state. The market is both ceremony and struggle.

It would be impossible to conduct as systematic a mapping of farmers markets in Havana, which are held daily (except Mondays). Stalls changed hands with sometimes dizzying frequency, and while certain kinds of produce were allocated to certain areas (meat vs. vegetable products, for example), there were no discernable hierarchical bases related to gender, ethnicity, race or occupation. Beyond the marketplaces, a structural organization of entrepreneurial activities was even less apparent; often the location and choice of work for the self-employed had more to do with accidents of fate or a person's specific set of proficiencies. Still, I adopt roughly the same interpretive approach as Gell when considering the political struggle enacted through the "morality of invention" among Cuban cuentapropistas at large. Framing this in more recent theoretical terminology, I examine the regimes of value that invento practices constitute and organize. This kind of work is what Austin-Broos refers to as a "phenomenology of the subject":

With these types of tools we can get a sense of how the re-positioning of people within transnational economies and modern bureaucratic states is negotiated over time. In this schema we include production, changing social imaginaries and new forms of practice along with conflicting regimes of value — and efforts to connect the present to the past. These are the co-ordinates of the subjects we address. (2009: 308)

Altman (2009) offers a somewhat more pragmatic, and programmatic, answer to the question of what economic anthropology is good for, and one that I find more 
compelling. He applies a "hybrid-economy" model of aboriginal production in northern Australia to show how that which his subjects do for a living does not neatly fit into the "real" economy policymakers tend to invoke.

Here again anthropology assumes the mantle of speaking against neoliberalism as "the globally dominant theory of political economic practice" (Altman 2009: 318). Following Harvey (2005), Altman defines his theoretical rival as one that correlates human welfare with the liberation of large-scale (read: corporate) private enterprise, the strengthening of personal property rights, the opening of the free market and the fantasy, always on the horizon, of free trade. In fact, he argues, policies that seek to further such ends inevitably disrupt local systems of production that mediate the influx of capitalist values through particular economic rubrics integrating multiple realms of activity, from the "traditional" to the "modern." In the Cuban context, my findings suggest, it is the authoritative state itself that is responsible for the disruption of the local systems of production (and local morality) that were themselves the product, in part, of actually existing socialism. If only for this reason, social action in the Cuban market of invention is already as "political" as it is "economic."

\section{Political Anthropology: Power, Hegemony and the Nation-State}

In the same way that I often heard Cuban entrepreneurs speak of their distaste for "savage capitalism," I also heard, over and over again and in various contexts, lamentations of "things that should not happen." This phrase referred to hardships great and small and implied a corollary: "this" should not happen — no milk, even for 
children, on the ration card, no potatoes in the market, no room on the city bus after waiting for an hour — and so we make up for this problem by taking matters into our own hands. "This" should not happen, therefore this does: We collude, we "resolve," we invent.

The phrase "things that should not happen" referenced not only hardship. In many cases, the Cubans I knew used it to describe a particular kind of hardship brought on by the exercise of state power in the everyday lives of cuentapropistas and other entrepreneurs who were struggling to get by. In other words, calling "things that should not happen" by this name, and in this way, was a de facto political statement.

This first dawned on me during my preliminary fieldwork, when the phrase passed through the lips of a new friend as we watched a poor rickshaw driver handcuffed and taken away for giving an illegal ride to a foreign tourist. The scene set off a clamor in the street and some women, one of them the driver's mother, spewed vicious insults at the police. In retrospect the image strikes me as prefiguring much of this project's ethnographic and theoretical basis: the rickshaw made from spare parts as a symbol of Cuban inventiveness; the driver and his friends as practitioners in a complex web of reciprocity; and the police as regulating agents of the state, hardly enjoying their task, and unsuccessful in disciplining minds and bodies. No one who witnessed this believed the police were justified in their actions, nor however were they especially frightened or concerned for the bicitaxi operator. There were ways to fix such problems; they would cost money, but the accused might find himself better placed, in the end, to carry out his work than when he left his house that morning. 
Action in the invento market, as this example shows, carries political consequences. This is true in at least two senses. It can get you arrested. But, critically, it also fosters an alternative political subjectivity and, indeed, reappropriates political propositions forged over time by the socialist state. Understanding this predicament necessitates bringing the state and the economy "back together," so to speak, in theoretical terms (Mitchell 1999). In this section, I discuss the anthropology of politics and the state as it relates to the political consequences of the economic choices urban Cubans make in their everyday lives. As I have suggested, the consequences of such action do not constitute "resistance" in a classical sense — which in any case has been rightly critiqued as having romanticizing tendencies — and these actions are not in any way understood as dissidence. But they do produce their own state effects. It is in this respect that I want to make clear what my ethnography has to offer to an anthropology of political economy. Like other modernist projects, socialist states rely on bureaucratic mechanisms of control that produce individuals and reproduce possessive individualism, paradoxical though this may seem. Yet, at the same time, they pump out a discursive cultural resource - an unapologetically nationalistic value-set rooted in solidarity — that allows socialist subjects (if only at critical historical junctures) to construct a socialist world on their own terms and, hence, the political alterity in which they operate. The authoritative discourse of the state (see Deleuze and Guattari 1987; Yurchak 2006) is reworked in everyday life such that individual creativity is valorized and then channeled through collective action, producing, as I have called it, competitive solidarity. 
This is not an effort, theoretically, to oppose "the state" and "society," or to reproduce various analogous (and equally false) dichotomies, such as private and public, official and unofficial, or formal and informal. In an early and influential treatment of this opposition, Clastres (1987) argued that, in effect, it epitomized the difference between modernity and the primitive. More recently anthropologists have complicated this idea by thinking of the dichotomy as itself a product of Western sociopolitical ideologies. In this vein, I build on prior critiques of the state/society dichotomy (Gupta 2005; e.g., Mitchell 1990, 1999; Mueggler 2001; Nugent 1994; Rose and Miller 1992; Scott 1985; Trouillot 2001). My approach is explicitly comparative, in that I am identifying two poles of social action in the late socialist Cuban context: one domain in which the dominant paradigm is "everyday invention" and the other in which the dominant paradigm might be called "authoritative normativity." But this does not mean that state power operates in one domain (the latter, one might think) as opposed to the other, but that the state happens differently in the two. The experience of the state is, indeed, cleaved between these poles, which I will refer to, respectively, as intimate vs. distant. People may shift from actions and statements performed at one end of the spectrum to those more appropriately located at the other, from day to day, even minute to minute, but they sense the radical disjuncture this entails.

This comparative approach is mandated not by a preordained theoretical lexicon but by the ethnographic situation as I came to understand it. In order to interpret how state interventions are lived and remade in the everyday drama of invention, we need to understand how the authoritative discourse works in other realms of life, such as those we 
observe in sanctioned state rituals and events, and what its own effects are, material and cultural (see Chapter 4).

In formulating a conceptual approach to state power, I have found Scott (1998) especially useful. He applies the Greek term mêtis to local forms of practical knowledge that state power, in its zeal to sustain order, selectively appropriates and sometimes defeats with disastrous effects. He uses it, for example, to show how German scientific forestry, conceived in high-modernist fashion to reap as much as possible from the land, led to its own collapse. This analytical perspective on the synoptic state need not be limited to ecological circumstances. When applied to the question of market moralities in urban Cuba, it suggests a compelling proposition: that practical know-how can, in reverse, grow parasitic on authoritative state institutions to such a degree that it subsumes and remakes them. Scott's own argument gestures toward a reappraisal and newfound respect for mētis principles. Where it misses the mark, however, is in reifying the synoptic state as monolithic rather than understanding its technocratic designs as operating in a continual feedback loop with their actual practice. Studies on Soviet Eastern Europe (which I take up in the next section) suggest how important practical inventiveness becomes as a form of everyday political praxis in socialist and postsocialist contexts (e.g., Berdahl, Bunzl, and Lampland 2000; Burawoy and Verdery 1999; Caldwell 2004; Ledeneva 1998; Müller 1991; Stark and Nee 1989; Verdery 1996). By focusing on the lasting influences of "actually existing socialism" and the ideology underpinning it, this work on a whole challenges the teleological story of socialist 
"transition" as too simplistic a framework for understanding Eastern Europe's — and by extension, Cuba's — political economy.

Concerns in social science for coercion and resistance are rooted in Gramsci's classic discussion of hegemony and Weber's on bureaucracy and state violence. Both theorists assumed the modern state to be a real and directly observable category of analysis. Writing from a Marxist framework, Gramsci (2006 [1934]) viewed politics as the systematic muting of a metaphorical and literal warfare of social classes. In this formulation the state acts with dictatorial impunity through "an ensemble of organisms" to produce the implicit consent of elites and subalterns alike. For Weber (2006 [1925]) the most salient feature of the modern state was its arrangement into a series of hierarchical bureaucratic agencies expected to operate, in ideal form, through a set of dehumanizing rules and regulations. Bureaucratic agencies thus covet their respective authority and obscure their practices of enforcement, producing a diffuse political system remarkably resistant to radical insurrection. Unlike Marx, who envisioned the dissolution of the communist state in the final stage of socialist revolution, Weber accurately predicted the over-bureaucratization of socialist states, recognizing that, in the absence of a capitalist market, governmental agencies would assume an ever-increasing role in public life, obviating the functions of civil society.

But this hard distinction between society and the state, implicit in the work of Gramsci and Weber alike, has been reappraised in contemporary theoretical and ethnographic analyses. Such work complicates not only what the state is but how it operates, both in the ideal and in practice. Wallerstein (1974) showed how modern states, 
already in the sixteenth century, were complicit in and perhaps born of global capitalist expansion. Gupta (2006 [1995]), in his study of corruption in India, demonstrates that the state is neither a unitary object nor a preexisting set of powers, but first of all an idea discursively constructed in everyday practice and mass-mediated texts, such as newspapers and television reports. Mitchell (1999) prefers to talk about "the state effect" rather than "the state," much as Foucault (2006 [1991]) speaks of "governmentality" as a complex of tactics by which people are transformed into individual subjects of state power, and populations into the primary datum of states. For these thinkers, the construction of social life, economic forces and state governance as natural and naturally separate realms of reality is a peculiar consequence of a modernist ideology that conceals its own historically contingent character.

Working from a separate front, political anthropologists have reconsidered the tendency to overemphasize hegemonic forces at the cost of undervaluing local agency and its creative reactions to dominance. Thompson (1971) is credited with inaugurating this tradition in an essay describing how eighteenth century English laborers used calculated forms of resistance to draw the powerful into a relationship of interdependence. This rather romantic view of the politically weak has been tempered, on the one hand, by studies on the ubiquity of administrative discipline, for example, in prisons (see Foucault 1977), and on the extent to which resistance functions as a “diagnostic of power" because it reinforces dominant cultural paradigms (Abu-Lughod 1990). This literature has been further complicated with more nuanced pictures of coercion and resistance as a dialectic interacting in variable and culturally specific ways 
(Scott 1985; Sivaramakrishnan 2005). As I have already suggested, there is reason in Cuba to agree with Li (2005) that the state is not, and can never be, as synoptic as its own aspirations, and with Herzfeld (2005) that even bureaucracies share in the production of mētis. Some evidence from work on civil society predating the Special Period supports the relevance of this perspective in the Cuban context even before the Soviet collapse (e.g., Baloyra and Morris 1993). My study seeks to add ethnographic grist to that earlier, speculative work.

A good place to locate a study about the dialectics of power lies at the margins of various practices of state power (Das and Poole 2004), where competing regulatory projects intermingle. Sanford (2004) offers a coherent example of this approach in a study on internally displaced Colombian refugees. The "margins," however, need not be understood as exclusively geographic. Indeed, what I am calling Cuba's invento market might be seen as an "array of margins" plainly situated amid urban life in Havana and elsewhere. Here, again, Scott (1990) suggests a useful rubric with which to attend to these arenas: the "hidden transcript." These unwritten texts provide recipes for everyday action that draw on state symbols and recode them in the enactment of social dramas. Understanding them requires a microanalysis of human relations as they unfold, and an awareness, as Greenhouse (2005) suggests, that state power also works through hidden transcripts. Chapter 4 examines the workings of such transcripts in Cuban political rituals.

As we shall see, national identity is among the more obvious registers through which hidden transcripts are performed in Cuba. As such, my project also engages by extension 
the literature on nationalism and the nation-state, with an eye toward effectively politicizing the questions it has so cogently raised. Handler (1988) and others have shown, decisively, how nations are constructs that social actors reproduce by imagining themselves to be united in a homogeneous essence, a continuous history, and definite boundaries. In the ideology of nationalism, the group is conceived as a possessive individual with ownership and motivations, while individual diversity is made into an object: property of a fundamentally uniform nation.

Anthropological thought on the nation-state in the past decade has grown concerned with the dialogics of national becoming — the political context in which nationalisms (plural) are situated and contested. National identity in this perspective is as potentially innovative as it is hegemonic. In studies on Japanese-Brazilian migrants (Linger 2001) and on the underprivileged in Mexico (Lomnitz-Adler 2001), the authors portray national identities as dynamic and relative, imagined in ways that shift focus from one setting to another and allow for people left out of the dominant discourse to rework their relationship to it. Spivak (1996) calls this “strategic essentialism." Claims to hybridity become at once essentializing and deconstructive, since cultural forms are objectified self-consciously and imperiled in their daily performance (Harvey 1996). Shryock (1997) shows that the conscious imposition of written history on oral narrative among Bedouin tribes served to contest Jordanian national allegiance through the construction of a counterpoised "genealogical nationalism," one based on kinship ties that resisted absolute objectification. 
Nationalism has, historically, been a key component of the ideology of socialist states. So it makes sense that at moments of crisis and change in the history of any socialist state, national identity as well as material survival would become a key locus of interest and action for people across the socioeconomic spectrum (Verdery 1991a). In Cuba, the subaltern political struggle occasioned through practices of market invention, as we shall see, is often expressed as a struggle over nationality and national symbols, while the valence of the nation, positive or negative, is itself contested. Ordinary Cubans might just as easily extoll the "Cubanness" of their inventive solutions to the problems of everyday life in one breath, and in the next lament (as one pirate taxi driver memorably put it), "how stupid we Cubans are" - this evidenced for him in the undeniable fact that nothing works the way it's supposed to.

\section{The Anthropology of Socialism: It's Not Over Yet}

The twentieth century's Cold War produced in the West a political science intent on describing everything that was flawed or lacking in the socioeconomic systems of the socialist bloc. An idealized vision of capitalism served as the standard measure of civilization against which socialist societies were expected to perform, and against which they inevitably failed. Though no less critical of socialist formations and their inherent contradictions, anthropologists have tried to rescue social science from this shortsighted perspective by understanding socialism on its own terms - its own "laws of motion"

(Verdery 1991b). The anthropology of work and consumption under socialism in Eastern Europe has helped show how some of those laws of motion played out in the real world. 
Understanding these contexts informs not only what socialism was, but also our current picture of the Cuban context and the so-called postsocialist transition.

Because the Marxist project tried explicitly to reorganize productive practices, here we have an arena of social life where we would expect to find fundamental differences between actually existing socialism and the capitalist universe against which it struggled. This is indeed the case, but ethnographic studies in this area reveal surprising facts when compared to the social science models critiqued in Stark and Nee (1989). Here I attempt to synthesize a sampling of these studies and comment on them in a useful way. Perhaps most strikingly they demand that we rethink the informal exchanges of goods and labor on which people in socialist Eastern Europe relied to supplement their livelihoods (often called in this literature the "second economy," or the informal sector). Whatever we call it, the unofficial sector should not be seen as a capitalist underworld of socialism, as it was often represented in the press. The studies I explore suggest that, while appearing to operate on capitalist principles, informal economies strengthened the significance of social status and produced overlapping networks of social relations. Ironically, it was official socialism that especially encouraged commodity fetishization, autonomous individuality, rational utility and profit maximization. Even this theory is an oversimplification, however. It gives the impression that these two realms, the official and unofficial, were neatly compartmentalized in people's lives. On the contrary, these studies also show that the formal and informal economies were products of the same socialist logic and deeply implicated with one another. Their interpenetration has had a 
major influence on everyday life during and after the socialist era in Eastern Europe (e.g., Dunn 1999; Humphrey 1995).

Lampland (1991) sketches out how ideas about labor, and labor itself, changed over time in rural Hungary, before, during and in the final years of socialism. Focusing on the agricultural second economy, she shows that private work activities were more than simply a byproduct of socialist engineering; they also mediated it. By the 1960s much of the work conducted in private fields and gardens was officially sanctioned, and by the mid-1980s the state fully encouraged growth in this sector of the economy. Although government leaders minimized the importance of informal agricultural activity in their official talk, they supported it in deed, morally and financially, offering private producers technical advice as well as advantageous prices for whatever grains, feed and livestock they needed (1991: 465-466).

That rural workers decided to intensify this sort of production on their small private plots can be seen as an unexpected consequence of socialist industrialization and "plan bargaining," Lampland argues. When the Communist Party took over in 1947 many villagers felt compelled to move to the cities to work in state factories as wage laborers; science and modernization were as much a part of this new ideology as they were the handmaidens of capitalism. The peasants who stayed behind fell victim to the machinations of bureaucrats endeavoring, as Verdery (1991b) has shown, to increase their redistributive power. By manipulating output estimates, fudging production figures and making official documents purposefully ambiguous, agricultural plans became selffulfilling tautologies. Elsewhere Lampland (1995: 255) shows how the "politics of 
science" figured prominently in the calculation of piglet mortality. She documents how farming managers in the town where she lived inflated piglet mortality figures so that a certain number of adult pigs, thus unaccounted for, might fetch them a profit in the second economy. Managers sought personal gain through such machinations, and villagers saw right through it. Alienated from their labor, many villagers turned to the privacy of their homes and gardens to remake themselves as social beings, to satisfy in this way their material and psychological desires (Lampland 1991: 472). As such, she finds, socialism had "fostered the attitudes it was founded to eliminate" (1991: 475), among both former peasants and their new bosses.

But the interplay of policy and social action also changed labor itself. The agricultural second economy, Lampland says, had roots in the pre-socialist era. At that time, what had once been an emphasis on the ownership of land had given way, under the incipient relations of capitalist production, to an emphasis on work as "possessing activity," the author's gloss for the Hungarian idea of dolog. Under this logic, peasants who worked their own plots of land - even if their lives were in fact less secure — had greater status than those who contracted their labor-power to a manor for extended periods of time. Hungarian peasants of the early 1900s deplored the idea of sharing their work and land with the impersonal forces of the market. It was not enough, however, simply to bow out of the market economy. Whoever controlled his own labor was expected, also, to put it to use. Idleness was shameful.

By the late socialist era, work was again being transformed in rural Hungary. The importance of the second economy, as produced by state policies, gave birth to a pair of 
distinct private work practices, divergent roughly along generational lines. Lampland found that older folk with a memory of the logic of dolog practiced private forms of production contributing directly to the household economy: they raised animals and tended to their gardens primarily for consumption in the family circle, only secondarily as a means of exchange. Their children and grandchildren by contrast calculated how much to produce as a function of time and money. The young forsook traditional staples like pigs in favor of high-priced products in high demand, like musk and tobacco. In time, labor had been fully commodified. It was now fetishized not as an activity for its own sake but, in Marx's terms, as an object of exchange value. Along with labor, Lampland argues, the rural Hungarian concept of the self thus had also been refashioned.

Attempting to engineer a collectivity, the state had succeeded in engineering individualities. Initially a social sphere for resisting such notions of the self, the second economy was fast becoming the prime place in which to realize one's individuality.

The picture becomes still more complicated when we compare Lampland's findings on the rural economy to the factory life that led so many villagers to flee to the cities of Eastern Europe during much of the last century. Burawoy (1988) offers a valuable account of working for piece rates in a Hungarian steel factory. On the shop floor, state control was exercised through the imposition of piece norms dictating how many times per hour a worker should complete a given task. Workers were paid on the basis of how well they fulfilled their norms. Often unrealistically high, these goals had the potential to drive workers to "fury and panic" (1988: 216). And yet, so went a typical saying, the Hungarian worker ruled in the factory. This saying was not without its grain of truth; 
Burawoy discovered that informal resistance to socialist practices and ideologies of control in this official work setting tended to produce the kind of class solidarity which the system claimed for itself as a key objective. The system, in turn, made use of control mechanisms that tended to atomize the workforce.

A close reading of some ethnographic details from Burawoy's text will help illustrate this paradox. Burawoy writes that the two factory institutions ostensibly designed to protect workers - the party and the union — were essentially ineffective. Party hacks were not trusted, and the idea of taking a grievance to a union representative rather than one's supervisor was something of a joke. Because managers flexibly deployed their workers, shifting them from machine to machine, workers often responded by becoming very adept at particular jobs. In this way, an individual worker could accumulate bargaining power "by virtue of his or her importance in the work process" (Burawoy 1988: 214). Here we see another manifestation, at the shop-floor level, of socialist power as redistributive in nature. It was not how much you could make, strictly speaking, that mattered, but what you could make and how well you could do it. And the easier it was to meet or exceed piece norms, the more time a worker could spend using the instruments of his labor on outside work, the side-jobs known as maszek.

The question of how much work constituted a worker's "normal" productive capacity, in any case, was something of a mystification. While piece rates appeared oppressive in principle, in practice they were successfully manipulated by workers as well as managers, often acting in collusion with each other. Burawoy tells of his friend János who, experienced as he was, never turned in more than 110 percent of the piece rates. 
Management, in turn, had adopted this figure as its own productive ceiling. In this way, by producing at less than their potential, workers and their factory as a whole avoided increases in rates handed down through the bureaucratic hierarchy.

This does not mean, as is generally assumed in comparisons of capitalist to socialist enterprises, that workers lacked personal motivation. Burawoy shows that workers maneuvered around such limits even as they set them. One way they did this was by conspiring together to post more hours than they actually worked. Because they were paid by the piece, this did not change their overall salary, but it did appear to reduce their overall efficiency (1988: 216). Such forms of unplanned solidarity were not uncommon. It was only Burawoy's first day on the job when he witnessed the intimation of this solidarity in a meeting between workers and management. Managers had called the meeting to justify a tightening of piece rates, but they also offered a salary increase in return. On other occasions, workers negotiated successfully to have managers tighten only those rates known to be "loose," or easy to meet. Because in this instance the ratetightening would occur across the board, the skilled workers in the author's employment unit were skeptical and many opposed it. It was adopted over their objections. Yet the fact that the meeting was held at all illustrated for Burawoy the "limited form of workers' control" (Burawoy 1988: 226) that was engendered, if accidentally, in an economy of shortage (Kornai 1980).

Burawoy tells us about daily life for socialist workers, how in fact they carried out the tasks expected of them. He shows how these tasks compromised the intended outcome of the organization of labor under socialism, but he only alludes to the vast world of activity 
parasitic on that organization. In a volume on Communism in Poland, Firlit and Chlopecki (1992) help fill that gap with an interesting taxonomy of informal practices that emerged from factory work. They show that the informal economy in Poland was not "second" in the true sense of the word since it occupied a central place in workers' lives and in the functioning of the socialist system. In one case, a manager ordered his inventory clerk to offer several jars of paint at no cost to a fellow worker, for use by the worker outside of the factory. In another, a mechanic repaired the shop director's car during work hours, leveling the hierarchical relationship between them. These "favors" and "services" were everyday experiences for people, ones they distinguished from outright theft and corruption. A worker who didn't oblige, the authors speculate, would have been thought of as antisocial or boorish. In the same way, acts of "arranging" and bribing between firms and individuals not only helped build social ties, but also allowed workers and managers to fulfill the requirements of the state plan.

Curiously, Firlit and Chlopecki conclude that such practices, while having the effect of integrating workers and encouraging cooperation, ultimately existed to promote their "personal gain" and constituted a culturally "pathological" outcome of the socialist enterprise. But their own data, I would argue, cast doubt on this simplistic conclusion. As the authors themselves point out, a worker's real or perceived underpayment did not correlate with his involvement in the informal economy. Nor did such activity occur without its own logic of morality: namely, that factory waste was immoral, while there was nothing immoral in the redistribution of material goods over which, by virtue of co- 
ownership in the means of production, one already had certain responsibilities especially when that material would otherwise go to waste.

While "personal gain" was certainly a motivation for much of this exchange, it is not a sufficient explanation. These practices are better understood as instances of reciprocity in Mauss's classic application of the term: total social behavior implicating its actors in a web of gift exchange. This fact is especially salient given that money was rarely the main currency of informal trade. There $i s$ a sense in which we might understand these practices as "pathological" - but it is not the sense that Firlit and Chlopecki propose. These practices were pathological in the sense that workers who were engaged in reciprocal exchanges, while re-appropriating property of the state, were acting in ways they understood as both necessary and illegal. More vexing still, they knew these actions to be more "social" than state socialism. Only in a narrow, Western-centric sense did this informal world promote "personal gain." More than personal gain, it promoted group solidarity.

This assertion appears to contradict what Burawoy and Lampland found among Hungarian factory workers and villagers. Recall that, in Hungary, Lampland saw village second economies transformed into realms of rational utility, and that Burawoy saw socialist policies create unexpected solidarity among steel workers. These perspectives can be reconciled, however, in a more nuanced understanding of second economies under state socialism: Wherever state intervention has served to legitimate and co-opt informal exchange, the work involved in such exchange took on more and more the character of alienated labor. Fully recognizing such tensions inherent in the structure of actually 
existing socialism will make it easier to understand the system's collapse as well as its current transformations in Cuba.

And yet amid the vast postmortem literature on socialism in Eastern Europe, Cuba hardly figures. In many ways it is the last, forgotten outpost of the Soviet empire. There's a temptation to assume that the Cubans simply haven't "gotten the message" from the mother ship: State socialism just doesn't work, and efforts to reform it merely lay the groundwork for its inevitable collapse. Never mind that the system has survived now for more than twenty years, more than a third of its lifetime, without Soviet subsidies. A simplistic retort might be that things simply got underway later in Cuba, and will take more time to unravel. For obvious reasons, such presumptions are empirically shallow and intellectually lazy. They provide a discursive escape hatch through which to duck the more appropriate question of what has actually been going on in Cuba.

To understand even a subset of what's been going on we must return Cuba to the Soviet sphere, conceptually, and draw on the best of what we know about the political economy of socialism. There are many ethnographic parallels to draw with respect to the workings of classic socialist practice in Cuba and the various reforms that have sought to address its shortcomings. What's more, evidence from Cuba in turn can help to inform what I have called socialism's postmortem literature. Many analysts writing in this vein, even those whose path-breaking work in the 1980s and 1990s speculated on the possibility of a "Third Road," seem to have accepted, tacitly if not outright, the aura of inevitability that pervades the more recent scholarship. 
In returning communist Cuba to Eastern Europe, another important touchstone is the work of Iván Szelényi, especially his analysis of "socialist entrepreneurs" in Hungary (1988), published the year before the fall of the Berlin Wall and based on extensive work in the preceding two decades. Szelényi describes how in rural Hungary a new petty bourgeoisie was emerging after decades of communist rule that, in theory, had produced a monolithic socialist proletariat among the peasantry.

The empirical work on which Socialist Entrepreneurs was based is primarily demographic and, where ethnographic, is analyzed from a quantitative more than qualitative perspective. Szelényi and his colleagues collected years of survey data on rural households and supplemented them with structured interviews and life histories organized around classificatory paradigms. Under my own research conditions, I could not hope to reproduce such an effort; nor, in fact, was this my objective. One reason is practical: the demographic data on entrepreneurship in Cuba simply isn't reliable or easy to access, and the systematic collection of household samples was not practicable in a sprawling urban area. More than that, however, the difference in approach has to do, fundamentally, with our differing theoretical orientations. Szelényi is concerned with class formation and class-focused theories of social change. While we share an interest in articulating a new political economy for socialism, and in reflecting on the relationship between individuals and power structures, I am concerned with the variable nature of markets, their moral bases and their thoroughly political shape. Rather than determining exactly how many people are involved in the private sector in Cuba or exactly how large this economy is, or how best to classify entrepreneurs (all interesting questions to be 
sure), I want to know what makes this sector tick — how do people operationalize it in their daily lives and what language do they deploy to understand and justify their actions?

Coming from a background in sociology, Szelényi might call this a more "culturalist" paradigm, though the label as he deploys it doesn't seem to be as fine-grained as its use among anthropologists. He is not opposed in principle to value-oriented considerations and relies on such approaches where necessary. Namely, he speculates that the “entrepreneurial spirit” in rural Hungary was kept alive across several generations, in no small measure, by means of the transmissions of certain attitudes (cultural capital, cf. Bourdieu 1977) rather than actual wealth, and mainly among identifiably middle-class people. It is when making such claims that Szelényi is most hesitant because, as he says, these are difficult matters to quantify. For my part, it is precisely that which cannot be quantified which, I think, needs most to be addressed and understood: that is, the ideology inherent in the particular market that Cubans invent. This is where Szelényi's analysis is most lacking. The moral aspects of the Hungarian second economy are not at all accessed in his study, which takes for granted that if socialist entrepreneurs are buying and selling surplus goods produced on their own free time, they are by definition petty capitalists or on their way to becoming so. When addressing their attitudes at all, he wonders, pessimistically, whether they are dominated by "greedy" personality types or not as civically minded as their Western counterparts (because they don't actively engage in dissident activities) or if they are promoting "corruption" in their dealings with the state apparatus, because they rely on bribes and payoffs to bureaucrats to keep their businesses running. Szelényi's implied "market" is not particularized but universal and 
the pictures of his informants as a result appear flat. I maintain, in the hopes of pushing Szelényi's observations forward, though in a different context, that we cannot successfully develop a new political economy of late socialism unless we also address questions of value, everyday praxis and discursive understanding — properly the stuff of anthropological inquiry.

\section{Ethnographic Vertigo and the Dilemma of Quasi-Native Fieldwork}

The field research on which this dissertation is based took place mainly during a fifteen-month stay in Havana from the beginning of 2007 through the first half of 2008 . I conducted preliminary research during a prior summer, and began visiting Cuba in 2003, just before entering the Ph.D. program in anthropology at the University of Virginia. But in truth, the island has been with me since before I can remember.

My family has roots in Cuba running several generations deep. One of my ancestors was a colonel in the second war of independence, another was a brigadier general in that same war and later a supreme court justice in the pre-revolution republic. Both of my parents were born in Havana in the late 1940s. They were barely adolescents when the Rebel Army poured into the city victorious. They remember the crowds and the euphoric atmosphere. My mother, according to family lore, once received a sweaty military cap from Fidel Castro, a gift he dedicated and signed in his own hand, sending it to her through her maternal uncle, who was friendly with el comandante in the early years of the revolution. The cap never made it out of Cuba. My grandfathers, both physicians, 
were among the many professionals who left the country in those turbulent early 1960 s, not knowing they would never return.

They did not settle in Miami, like most Cuban exiles. Work opportunities took them elsewhere. My parents met in their college years and raised their children, five of us, first in Virginia and then West Virginia, for much of our childhood. If a typical Cuban-exile experience exists, this was not it. My parents spoke Spanish at home, and we knew something of their past, of Cuba, in a dreamy sort of way. My father was an engineer, my mother a Spanish teacher. We did not speak of politics or economics or such things. We were not raised to harbor bitterness for an alternate life snatched from us by historical circumstances, or to pine for an impossible return. We were just kids, like our neighbors, born in the United States, with a bit of spice. When we moved to Miami years later, we discovered we were Cuban, too, just not quite as Cuban as we were expected to be. For high school I attended the same Jesuit school Fidel Castro graduated from decades before — it had relocated in South Florida, expelled by the revolutionaries.

This was probably when the idea of going to Cuba and seeing things for myself first occurred to me. Not having experienced the rupture myself, or grown up fully in the bosom of the exile community, the emotionally charged reality of the two Cubas cut off from each other by the Straits of Florida increasingly struck me as absurd. Today this division is softening, but in the 1980s and 1990s, between Mariel and the rafter crisis, to speak well of the revolution's ideals or its accomplishments, or even to proffer a moderate détente, was a dangerous thing. It seems the only common thread between the 
Cuban Revolution and its diaspora has been the oppression of oppositional thought, an oppression on which their respective narratives depend.

I did not decide to become an anthropologist in order to understand Cuba — how I came to the discipline is another story, and this is not the place for it. But anthropology did provide me with an intellectual lens, equal parts empirically rigorous and philosophically humanistic, through which to make sense of this peculiar place and my own relationship with it. It was, in that sense, a serendipitous encounter. In the guise of ethnographer, I could ignore a generation of sorrow and go to Cuba after all, and I could call it research.

Sociocultural anthropology involves the systematic interpretation and analysis of social and cultural difference. While "fieldwork" in this subfield could mean a variety of things — lurking in archives, reading texts, watching film and television, drawing maps and blueprints, analyzing statistics, conducting surveys, or any combination of these methods - the ethnographic encounter has remained, through more than a century of theoretical fashions and upheavals, the hallmark of what we do. It is premised on the idea that sustained and engaged participation in the lives of some discernible group of people reveals facts about them, and about human possibilities more generally, that the cursory experiences of the tourist or the journalist cannot. The writing of ethnography, in turn, presumes that with words and a theoretical framework of some kind, we can make some useful sense of our experience in the field, abstract some propositions from it and translate them for an audience, such that the people who teach us their collective practices and ideas — their "culture" — can be made intelligible in some other context, 
or perhaps seen in some new light, and thus made commensurable with our collective knowledge: the so-called ethnographic literature. It is all but cliché of course to point out that this endeavor brings our own cultural contexts into high relief in the process. That was the original meaning of "culture shock," and in the popular realm it remains the most valuable aspect of the discipline.

But precisely because it involves actual people and everyday life, ethnography is a messy business, no matter the context. It wants to structure and generalize, yet refuses to accept that we can impose a priori the categories of thought that should matter to our informants. Besides, we've given up on anything like a static, bounded notion of culture. We hardly utter the word culture out loud anymore, except perhaps in undergraduate classes, for fear of sounding prehistoric. Yet we cringe when we hear it stolen from us in public discourse, often badly. We distance ourselves from this monster of our own creation, sometimes dressing it with other words: power, habitus, "social formations." But we cannot deny that the concept of culture underpins ethnography; it is still what ethnography is about (see Bashkow 2004). This dissertation is no different, for it implies that the political economy of a people is first of all a cultural system - a symbolic order of socio-material values. As long ago as 1934, no one less than Edward Sapir noted that social facts, while certainly real, can never be accessed directly: they "are discoverable only as the peculiar property of certain individuals, who cannot but give these cultural goods the impress of their own personality" (1934: 412).

Just as anthropologists imprint them with ours. So we trudge on with the reluctant recognition that the ethnographer always stands between informants and audience as yet 
another subject, conveying a necessarily partial and caricatured view of things. We trudge on with the knowledge, as Wagner (1975) taught us long ago, that we "invent" culture in the process of describing it. In a comparable way, this dissertation shows that people variably "invent" the market. The fact of this invention does not make our invented things illusory. Culture and "the market" are real enough, no less real than language and skyscrapers - which are, like everything else, at once the products and media of culture, and impressive ones at that. Culture is real enough; we just cannot hope to pin down any one culture as timeless or seamless.

Instead, we describe what parts of a culture seem most salient, as thickly as we can (Geertz 1973), and apply this knowledge, often in a critical mode (Marcus and Fischer 1986), to a focused debate on the general potentialities of human existence. At its best, I am convinced, ethnography should also address some pressing public debate in the process; and so I will not shy away in this work from suggesting a few pragmatic implications. In an era when the world appears less and less diverse, when the ideology of global capitalism seems to dominate everything, anthropologists still uncover difference and disjuncture, for better or worse. We must therefore stand up to the seductive notion, so prevalent in our sister sciences and in common sense, that the complexities of life can be reduced to naive laws of human biology.

This perspective characterizes more or less the approach I take in my analysis of urban life in late socialist Cuba. In setting down basic facts about myself, my intent has been to situate this analysis in an honest way — without at the same time indulging too much in a deconstruction of the self that might detract from the subject at hand. 
Having a Cuban background is relevant, in any case, for at least this reason: It put me in an awkward position in the field, complicating tremendously the process of securing visa approvals for me and my family. When you know your time and budget are limited, these complications are stressful. I wanted to meet as many people and gather as much information as I could, as quickly as I could. But my friends operated at a different pace. Just the paperwork to stay in the country required dozens of repeat visits to government offices and took precious time away from my fieldwork - until I resigned myself to the fact that this was, in fact, part of that fieldwork: a window into operations of the state at the level of interpersonal relations. In the time I spent with bureaucrats, academics in official institutions and ordinary citizens alike, I could not simply get to the heart of what interested me. I learned to be aware and respectful of what interested them. And often, to my consternation, what interested them was me. They especially wanted to know my thoughts on Cuba as an American of Cuban descent.

What did I think of the Revolution? Where did my parents grow up? When did they leave? Virtually everyone had a connection of some kind to the United States and the exile community — an aunt, a sister, a son, a childhood friend. Did I know Fulanita de Tal? Could I take a letter to her on my next trip? Could you bring back a DVD player for my family from Wal-Mart?

This experience made me acutely aware of the ways in which I was so different, how I was, as it turned out, not actually Cuban in their view, or only imperfectly so. For one, the Cuban language varieties spoken on and off the island have diverged over fifty years of separation, as linguistics would predict. I spoke Spanish a lot like my hosts, but with 
obvious deficiencies. Common sayings, slang, the endless abbreviations of state enterprises, all these were at first a mystery to me. Unavoidably, I carried myself differently, and dressed differently, and acted differently. One consequence of this was that frequently I was expected and required to pay more for things. In the dual economy, Cubans still paid one price for certain goods and services, like bus tickets and museum admissions, and foreigners paid, in divisas, about twenty-five times more. The exchange of gifts, as in many ethnographic encounters, became a critical source of knowledge and practical survival. When my daughter, Lucy, got an ear infection, we were able to see a neighborhood doctor. When her mother, Ophelia, became pregnant with our second child, our friends helped us access free medical services usually reserved to Cuban citizens.

Being in the field with a spouse and a three-year-old had its own complications and rewards. We needed more space than most visitors, we craved at times more privacy. But on a whole, it was an exciting and personally fulfilling time. On a few days, Lucy tagged along with me to the farmers market where I spent much of my time, and she developed friendships with the children of several informants. Being a father, and being in a committed relationship, served to confer the status of adult on me in a way that many Cubans my own age did not enjoy. Ophelia, a gifted photographer, took thousands of pictures for herself and for my research, and we shared some of these with our Cuban friends and relatives. (The photographs reprinted in this thesis represent a small fraction of her work.) The handful of second- and third-cousins of mine who had remained in Cuba welcomed us into their family circle. And though we had known them only a few years, they treated us as though we had shared a lifelong bond. They taught us how to get 


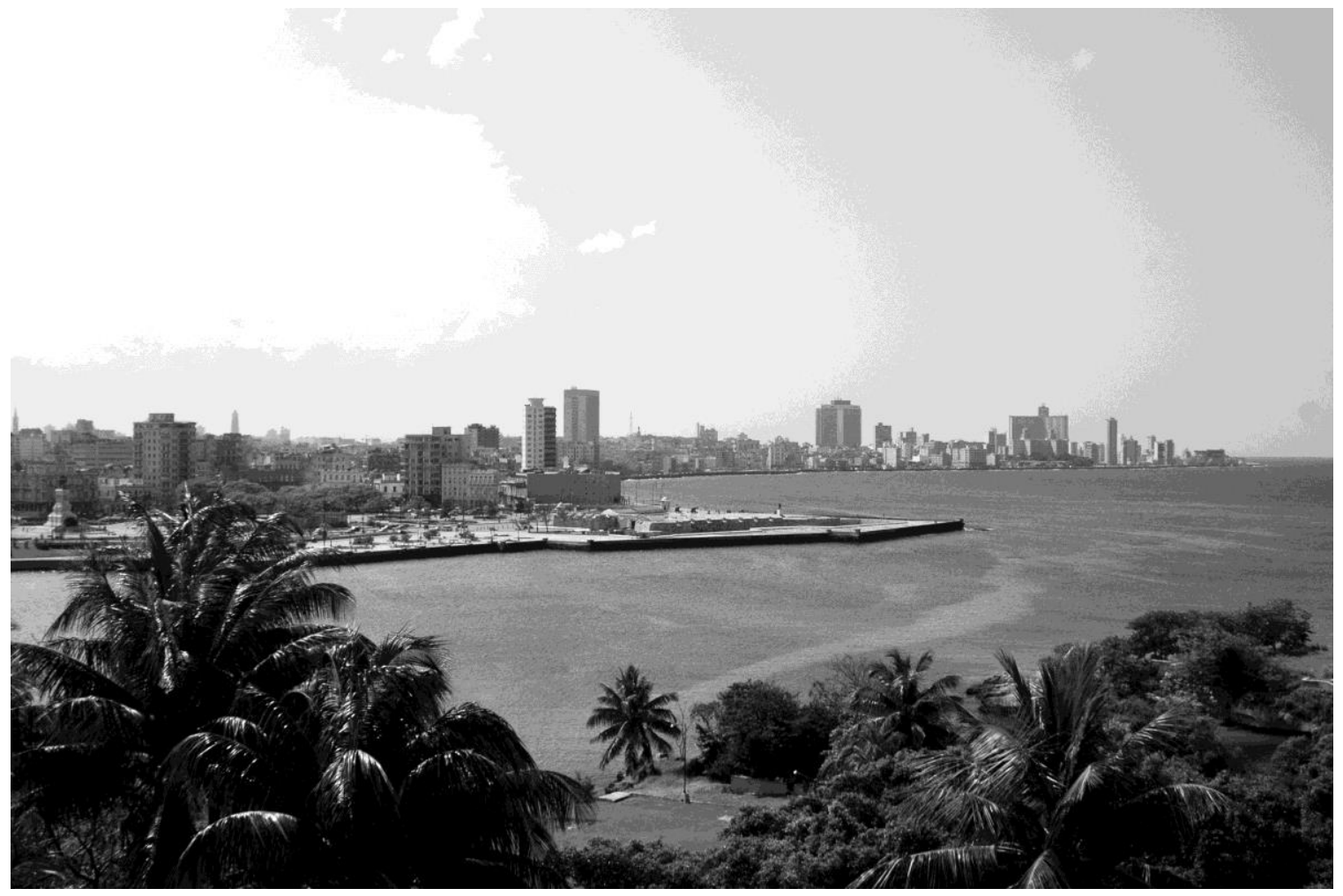

\section{PHOTOGRAPH 1.2}

Havana skyline. View from the east across the bay.

around in Havana and where to find daily necessities, and they shared long conversations over strong coffee and stronger rum after supper on many weekend evenings.

Founded by Spanish explorers in the early sixteenth century, Havana (La Habana) is Cuba's capital and largest city, with more than two million residents at the time of the 2012 census. It sits on the northern coastline, about ninety miles south of the Florida Keys. Throughout four centuries of Spanish colonial rule, Havana's port — graced by a bay with a narrow inlet and three finger-shaped harbors — was a key strategic military and economic gateway to the Americas. Vast amounts of wealth moved through the city on its way through the Caribbean to the mother country. Following a brief occupation by 


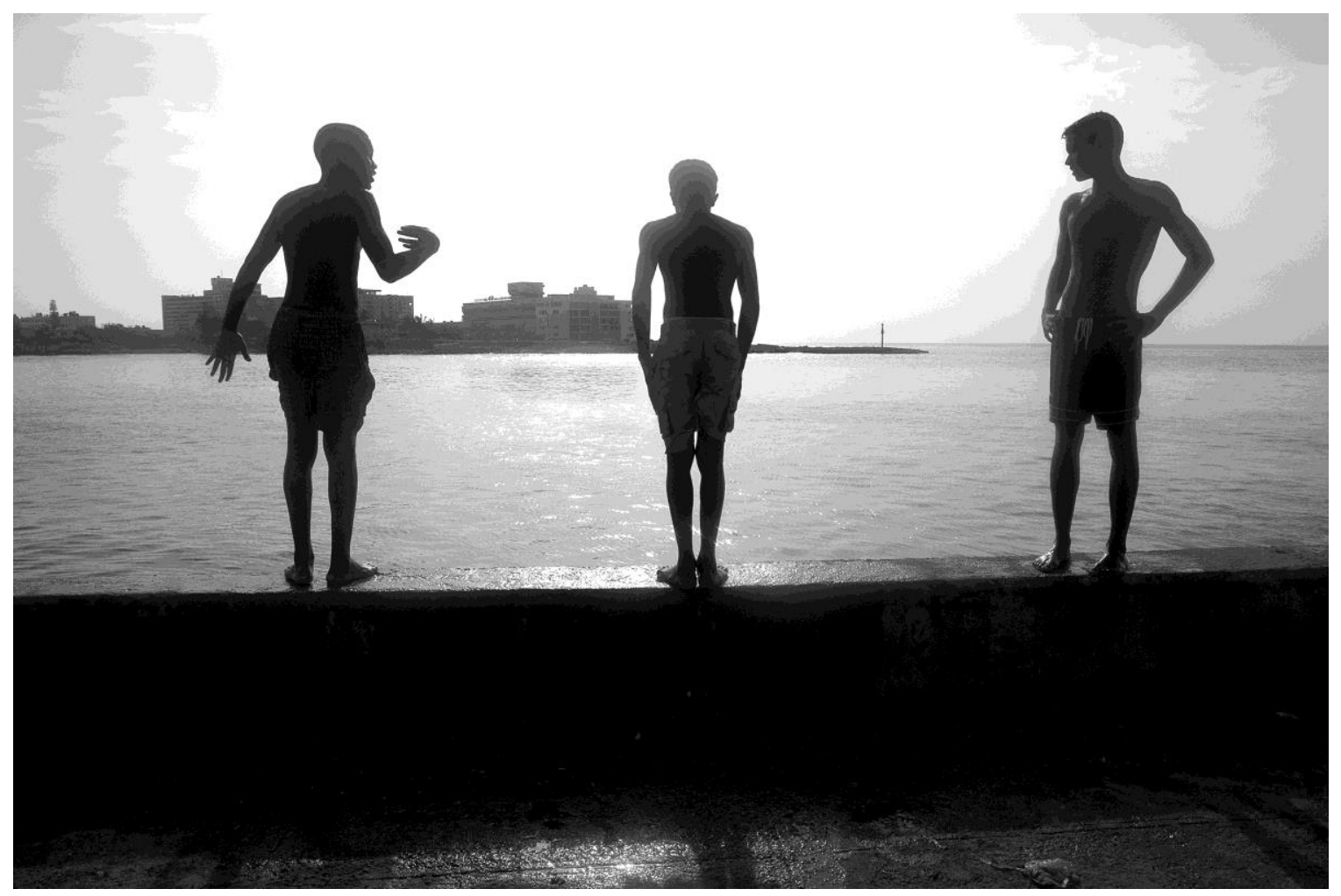

\section{PHOTOGRAPH 1.3}

Boys diving from the edge of the Malecón.

the British in 1762-1763, which transformed Cuban society practically overnight, the city became one of the most heavily guarded in the New World, with several fortresses erected at the mouth of the bay to complement a coral wall protecting what has come to be known as Old Havana (La Habana Vieja). A few sections of the wall remain today, but by far the most archetypal visual image of the city is now the Malecón, a broad boulevard with a pedestrian walkway and a seawall stretching four miles from the bay to the Almendares River, built under the direction of the U.S. Army Corps of Engineers following the wars of independence. (Construction began in 1901 during the American military occupation, and was completed in 1952.) 
By the end of nineteenth century, the city had already grown into a fashionable cosmopolitan center, as the Spanish crown loosened its grip on Cuba and trade with North America and the rest of the Caribbean opened. At the time of the revolutionary victory in 1959 , much of present-day Havana already had been built out, mainly to the west of the bay. Since that time, only a smattering of high-rise hotels and Soviet-style apartment complexes have been added to the suburban skyline. Havana proper is really three cities in one, each major section corresponding to a different period of significant growth: Old Havana, predating the British invasion of 1762; Centro, or downtown, representing the late colonial expansion beyond the city walls; and Vedado, an upscale neighborhood constructed in the first half of the twentieth century, designed with wide sidewalks and block parks, today part of the somewhat larger municipal division known as Plaza de la Revolución.

I conducted most of my fieldwork in and around the city's largest farmers market, known as Cuatro Caminos. The market is located in a crumbling neocolonial building at the southwestern edge of the old city, bordering the downtown district to the north and other populous neighborhoods to the west and south. I was attracted to Cuatro Caminos both for its centrality and, equally important, because it is a magnet for the kinds of economic activity I wanted to study. Vendors at the market, as with most other open-air produce stands around Havana, operate fairly independently, as licensed cuentapropistas and employees. But self-employment, legal and otherwise, extends well beyond the market building, into its portico and the surrounding neighborhood, where businesses of all kinds operate on the sidewalks and out of the driveways and front doors of people's 


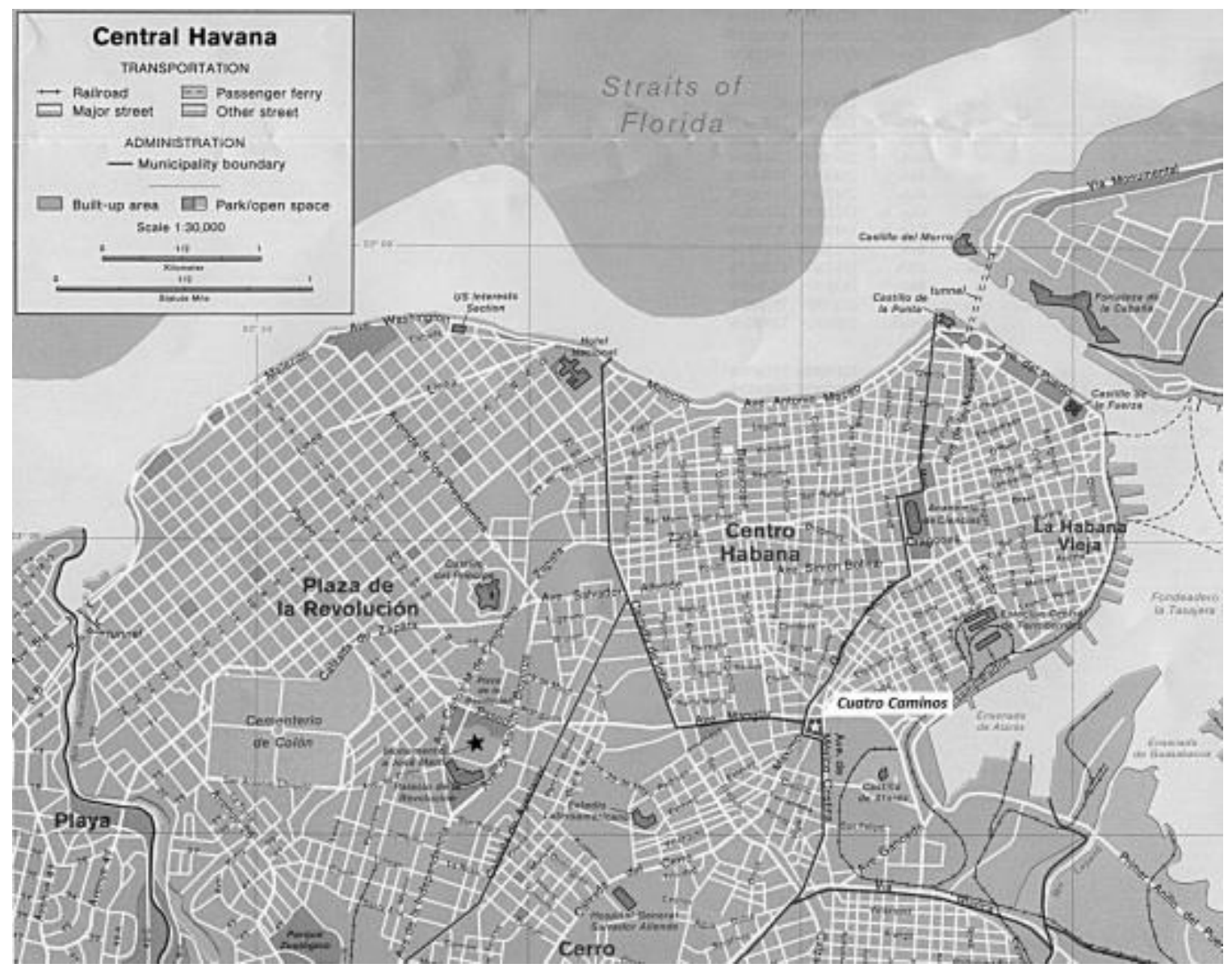

\section{MAP 1.3}

Central Havana. Cuatro Caminos sits at a major crossroads between downtown and the old city.

homes, taking advantage of the busy traffic. This entrepreneurial activity was not unique to Cuatro Caminos, but by all accounts this area could boast of an extremely high density of invento practices, along with the kinds of social relations inherent in them, making it an ideal venue for my study.

Nevertheless, for practical reasons, I chose to live in Vedado, about two miles away from la plaza, as the market is known colloquially. Even this short distance was enough to provide me with a contrasting view of life in Havana. In Vedado (and in Miramar, 
which is just across the Almendares from Vedado and home to many diplomats and multinational executives), residents tend to be better off than the average Cuban, either because they benefit from a steady stream of remittances or because they have otherwise tapped in to the hard-currency economy. While they are no less implicated in invento, it bears noting that theirs is increasingly oriented toward consumerist interests. This dissertation does not attempt to compare my two experiences of Havana. I wish only to note that while my conclusions are informed by both realities, my work was rooted primarily in the working-class culture that predominates at Cuatro Caminos, and in the more rundown areas of Centro, Old Havana and the outer suburbs to the south and east, as this was where I spent most of my time.

It took great effort and engagement to build trust in a political culture where lack of trust - especially of Cuban-Americans, long vilified in the state press as "worms" runs high. Over time, I met and had productive conversations with no less than a hundred and fifty people, a quarter of whom I came to know well. At the farmers market and in the surrounding neighborhood, my closest confidants invited me to work in their businesses and run errands for them. In these cases, I managed to conduct structured interviews or, at least, set down observations from prolonged encounters. Audio recordings were generally out of the question, so I took handwritten notes throughout the day and, twice a week or so, spent an evening typing them out and expanding on them with every detail I could possibly remember. I cannot claim, in the end, that the sample of people from whom I drew most of my data was randomized or controlled in the experimental fashion. They represented people whose lives fit the kinds of questions - 
about material life and exchange - I wanted to explore, and they were willing to talk to me. The point ultimately was not to build a statistically verifiable survey of small-scale entrepreneurial activity, but to understand the cultural grammar through which these practices took place. The idea of focusing on them through the native trope of invento, indeed, came to me somewhat after the fact, as I sifted through my notes, coded them on their own terms, and found patterns that I had missed in the field, or at least, of which I was only vaguely aware at the time. I am confident that my findings, while they emerge from encounters with a necessarily limited set of people in a large metropolitan area, give a fair portrait of cuentapropismo in urban Cuba at the time of my research.

I also spent much of my time attending state-sanctioned celebrations, commemorations, cultural events and seminars; visiting archives for authoritative texts and historiography of the Revolution; and watching TV news or reading the Communist daily newspaper, Granma, for a sense of the official discourse. These served to complete a picture of the political economy of everyday life, and provided me with more questions to put to my informants in our informal conversations, by way of comparison.

Many times, especially when I felt weighed down with the disillusionment and malaise that was so prevalent among my informants, I had doubts about my ability to maintain an appropriate measure of ethnographic distance from my field site. At other times I became convinced, to the point of paranoia, that a friend might be taking advantage of me, or feeding me only what I wanted to hear. I suspect this is something all ethnographers go through at some point, but for a Cuban-American in Cuba, the experience can be especially disorienting. I came to think of this as "ethnographic 
vertigo." Constantly, I dealt with it by reminding myself that my objective was not to resolve once and for all the question of state socialism's costs and benefits, in a mechanistic way, as though the Revolution were some monolithic entity, but to analyze how a multifaceted set of ideas and practices was being lived in the present context. In the darkest of hours, I reread portions of Peter Metcalf's gem of anthropology, They Lie, We Lie (2002), which I kept near my bedside. As Metcalf tells us, the Berawan began all their mythological tales with the simple caveat that the ancestors were no more honest then they. Like the Berawan, Cubans are fabulous tricksters. But even in trickery and deceit there is a kind of truth that only ethnography can appreciate. So, as Metcalf advises us, let's get on with it.

\section{Chapter organization}

The body of this work is organized in three chapters. The first is predominantly historical and contextual. It introduces in greater detail the Havana neighborhood where I conducted much of my field research and the farmers market at the center of this inventive world of entrepreneurship. From here, I move backward in time in an effort to situate more clearly the present circumstances, through an analysis of the Revolution's history. Then, returning to the present, I compare attempts by Cuban and non-Cuban scholars to understand the everyday practices found in such activity, showing how they rely on an impoverished and universalistic notion of the "market." This notion colors both how scholars interpret the data in question, and the sort of data that are salient to 
begin with. I conclude with a theoretical discussion of markets as morally embedded, and therefore culturally specific, institutions.

The next chapter develops the moral paradigm of "competitive solidarity" through a sustained ethnographic analysis of invento. In everyday practice the core features of competitive solidarity are brought to life. I address these interrelated features in turn, tracing their production through exemplary events, key moments, life stories and recollections, and direct observations of exchange. In the second half, I explore how competitive solidarity makes "intimate" the state, reshaping state power at the level of everyday life while also reproducing a "distant," spectral state. This should not therefore be understood as a romantic politics of resistance, but a pragmatic politics of invention. And the conceptual result is not an idealized state socialism but, in a manner of speaking, a humanistic "people's socialism."

The last core chapter explores how this struggle over the politics of morality is all the more trenchant in late socialist Cuba because the kind of moral subjectivity that the distant state tends to foster is rooted in a range of contradictory dispositions that are manifestly opposed to the morality of invention. To this end, I marshal ethnographic data on political rituals and their symbolic constituents, and on the modernist workings of the state-sector economy. I also show how my research participants experienced this struggle in farcical encounters, expressed it in tragic humor, performed it regularly in acts of duplicity, ennui and indifference, grieved it in various "things that should not happen," and embodied it in their widespread disillusionment about the future. 
Following these ethnographic chapters, I conclude with a brief discussion about the wider implications of my thesis and about the place of anthropology in public discourse. This discussion considers potential avenues for further research on "market moralities" and the political economy of everyday life. I also outline possibilities for productive political engagement between Cuba and the United States, in light of my ethnographic findings and recent changes in state policies on the island. 
¡Esta vez sí que es la revolución!

- Fidel Castro, 1959

\section{THE REVOLUTION AND THE MARKET}

Entering the Cuatro Caminos farmers market gave you the feeling of entering an airy cave. With no electric lighting, Havana's largest agro (as Cubans colloquially call these markets) might have struck a visitor at first glance as a gloomy place, so piercing was the contrast with the light of day. Passing below a high ceiling, cracked and weighed down with some ninety years of age, it took a few minutes for the eyes to adjust. Most of the produce stalls, or tarimas, were made of weathered strips of plywood lined in several rows stretching the length of a baseball field. A single row, where a few meager state-run tarimas operated, was situated along the back side of the market and built of massive slabs of concrete. When foot traffic was light, workers sometimes leaned against a wall or sat on rickety wooden crates stacked two or three tall, gazing off at nothing in particular, the smoke from their unfiltered cigarettes floating up from their mouths in a haze. Often they dozed off between customers.

For an outsider like me, it took longer still to adjust one's thinking to the kind of activity that permeated life at the market. It was not actually a sleepy place, even if at times life there seemed slow and dull. This market, known to those who frequent it simply as la plaza, bears the proper name of the surrounding neighborhood. Cuatro Caminos means "four roads." The name references the intersection of four city streets, three of them major throughways. The plaza occupies the entire block bounded by those 


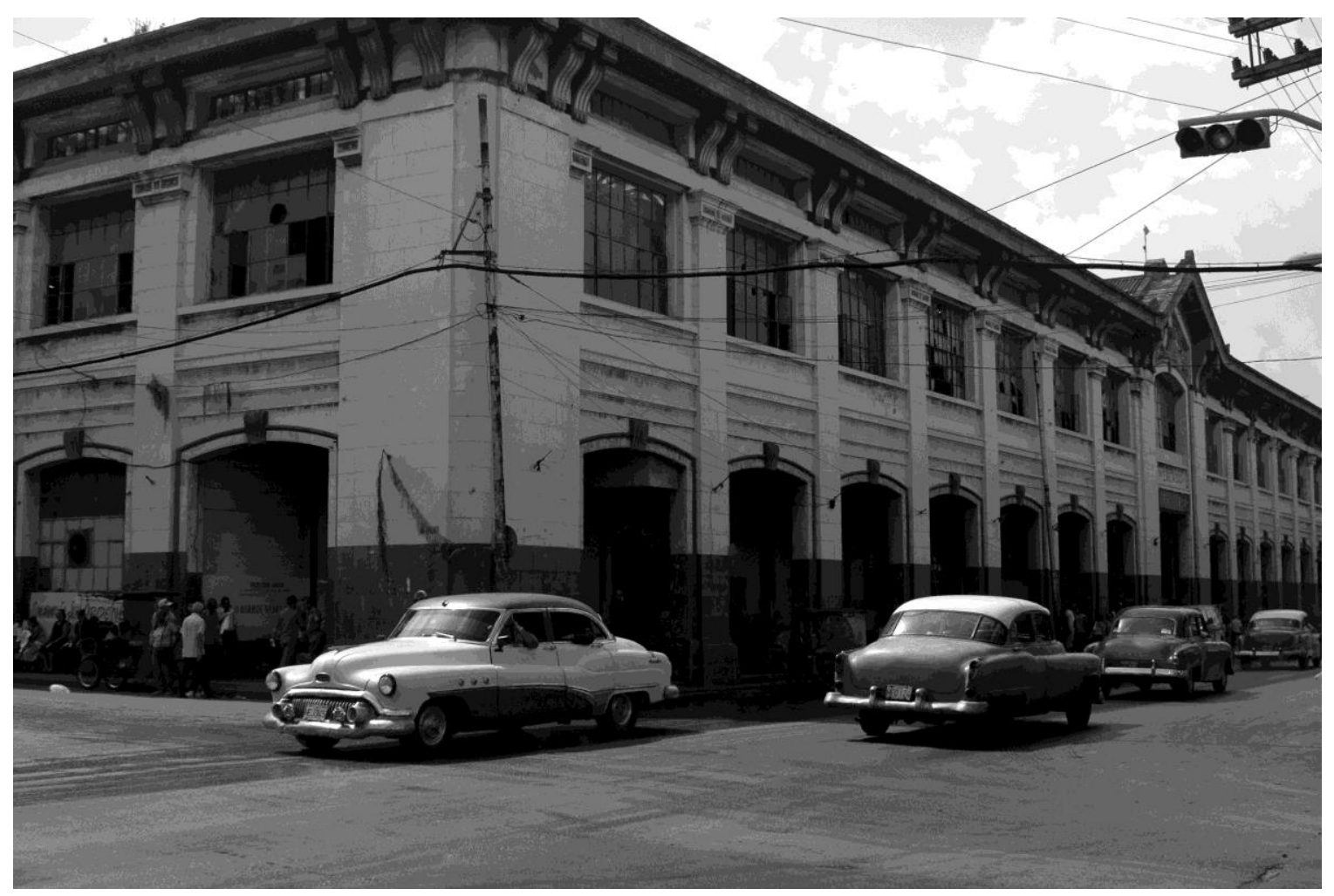

\section{PHOTOGRAPH 2.1}

Cuatro Caminos, exterior view facing southeast.

streets, in a vast two-story solid stone building constructed in the early 1920 s to serve as a wholesale point for goods of all kinds. It was, at its inception, a commercial center of gravity for the city, known then as El Mercado Unico, or "the only market." This bygone name, still painted on the building's outer walls, was derived from an early twentiethcentury municipal ordinance declaring that no other wholesale marketplaces could exist within 2,500 meters, and no others could exist at all without special approval of the city council (Hernandez Cartaya 1918). Old-timers recall the building, in the neocolonial days, as a mecca of capitalism, shining and packed wall to wall with commercial 


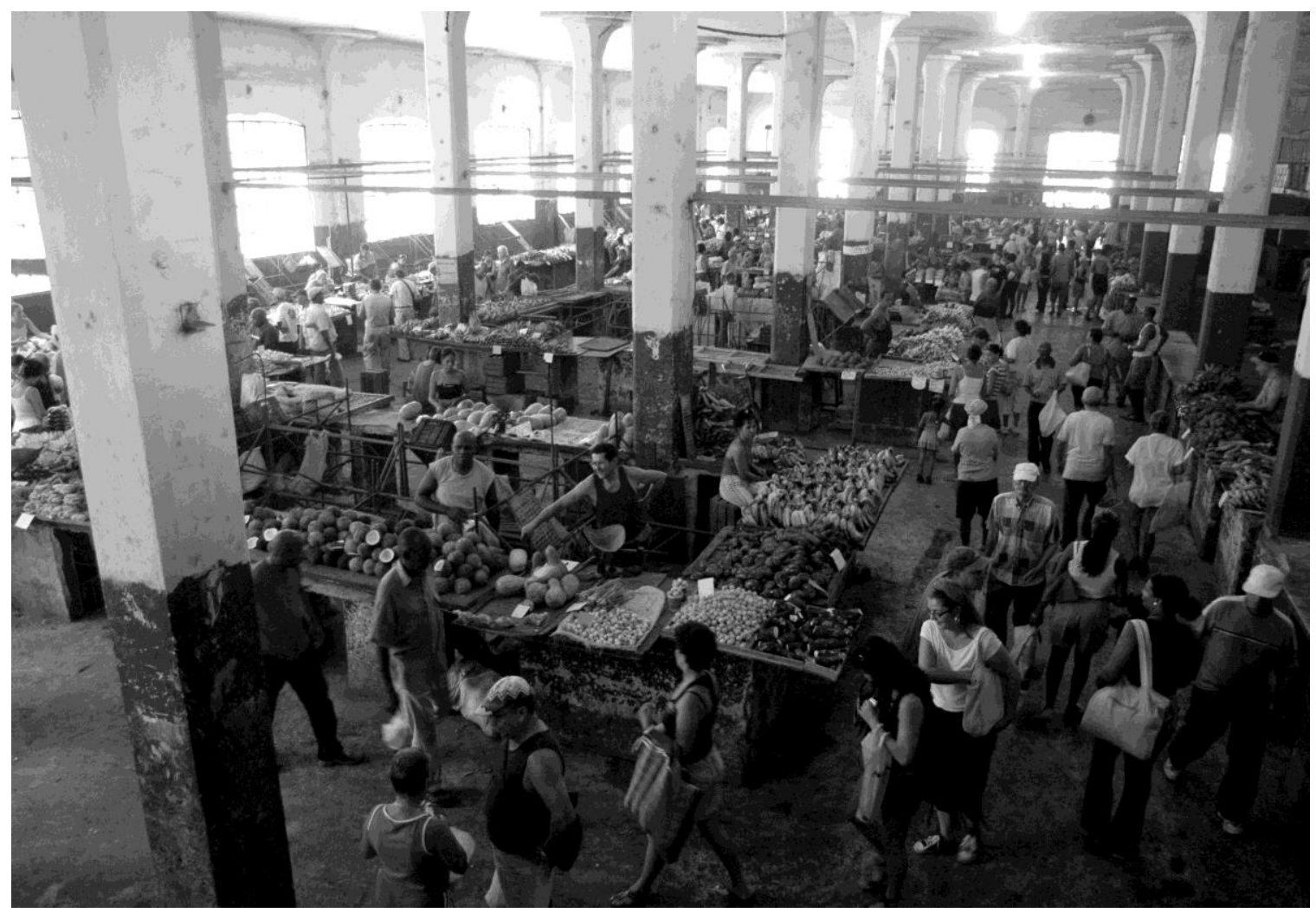

\section{PHOTOGRAPH 2.2}

Cuatro Caminos, interior view from above.

products, barber shops, restaurants, bakeries. These memories, though distant, still form a significant part of the imaginary through which the market is historicized in daily life.

The building had long since fallen in disrepair, virtually abandoned, when the Special Period arrived in Cuba. It reopened in 1993 as one of the capital's few arenas of private enterprise, part of the Revolution's experiment in improving food distribution across the island. Like many other open-air farmers markets in Cuba, Cuatro Caminos became a site for exchanging more than the typical produce from the countryside, including pork, beans, manioc, tomatoes and mangos at market prices much higher than those available to Cubans, in an increasingly limited fashion, on their ration cards. As anyone in Havana 
knows, Cuatro Caminos is a place where residents go to resolver, that is, "to solve things, to get things done." Perhaps more than any other area of the city, the plaza has a dual reputation, as earthy and seedy, but also a place you can't live without — the destination of last resort when, say, you can't find a handle for your broken coffeemaker anywhere else. When I mentioned to a private Spanish teacher who lived in a more affluent suburb to the west that I often lingered downtown, at Cuatro Caminos, she offered me a frown in mock disgust and said, "But Robertico, that's not where you go to find culture!"

"Well," I replied, "at least I got a pretty good deal there on a used bicycle."

"Oh, well, that's true," she said, laughing. "If you need something taken care of [resuelto], then that's the place. If they don't have it at Cuatro Caminos, you won't find it anywhere."

I spent much of my time working in the agro and familiarizing myself with the neighborhood because, as my eyes adjusted to the light and the life, I realized this place offered a microcosm of the kinds of everyday contradictions I wanted to understand better. In focusing on the plaza, I don't mean to suggest that Cuatro Caminos is "average" or "representative," but that it is, as anthropologists like to say, "good to think," because it offers a concentrated medium for the production of late socialist realities and the renegotiation, in everyday practice, of state designs, economic orders and nationalist discourses.

This chapter serves to contextualize my ethnographic analysis on three levels. On one level, the field site in question is "Cuba," not in the sense that there is a certain unity to the island, or that it is typified in entrepreneurial activity, but in the sense that people 
themselves think of Cuba as having this unity, and of invento as fundamentally Cuban. For this reason, it is necessary to further historicize the Cuban experience, with a special focus on social development following the revolutionary victory of 1959 , and the various cycles of transformation that produced the present circumstances. Here the claim is that these historical circumstances have made possible the particular moral paradigm in which the invento market is realized.

On another level, the farmers-market phenomenon constitutes the site of experience in and around which the ethnographic encounters I explore are situated. Following the historical section, I then analyze key scholarly works about the growth of agros during the Special Period. These are representative of texts that have been produced from both the perspectives of insiders and outsiders. The terms "inside" and "outside" are drawn here from a native discourse about Cuba that explicitly differentiates between the Revolution as national and adentro (inside the island), and capitalism and the foreign as afuera (outside the island). My analysis, however, calls this distinction into question, showing how both scholarly perspectives ultimately conceptualize "the market" in a similar framework - one that adopts the basic assumptions of orthodox, neoclassical economics.

In the last section, I begin to outline in greater detail an alternative ethnographic interpretation of the invento market, beginning with the experience I have come to think of as my own rite of passage into this world. On this third level, the relevant field site is both a physical place and the idea of the market that emerges from it. Here I differentiate my interpretation of the ordinary experience of invento from prior work on 
entrepreneurship and everyday life in contemporary Cuba. This requires revisiting, briefly, the literature on socialism and postsocialism in Eastern Europe, staking out a definitively moral viewpoint on late socialist self-employment and markets in general.

\section{The Evolution of the Revolution}

The historical account that follows touches on several key themes: the contingent unfolding of the revolution of the 1960s and its sociopolitical precursors; the radical social and economic transformations it wrought following the victory of rebel forces; and the legal institutionalization of the one-party regime in subsequent years, becoming what we can think of as the Revolution, with a capital R. In exploring these themes, I will show how it is possible that the Cuban Revolution as institutionalized could engender moral dispositions of collectivism and solidarity while, at the same time, deep skepticism about the relevance and legitimacy of the socialist state. Because the historiography on which I draw (especially Pérez-Stable 1999) is rich and, generally speaking, culturally informed, I do not strive for a revision or critique per se, but a productive synthesis (see also Baloyra and Morris 1993; Dalton 1993; Fernández 2000; Pérez 1999, 2008, 2011; Robins 2003; Rosendahl 1997; Thomas 1998; Whitney 2001).

Because the revolution was in many ways a creature of American imperialism, the turn of the nineteenth century, which marked the beginning of sustained U.S. involvement in Cuban affairs, is an appropriate place to start. Following the American occupation of 1902 to 1906, the United States repeatedly intervened in Cuban affairs during an era known in Cuba as the "neocolonial" period. Today, U.S. economic 
sanctions bar the island from potentially billions of dollars in trade with its biggest geographical neighbor. In the United States these sanctions are referred to as the embargo, but in both official and informal discourses in Cuba the embargo is "the blockade," a term that emphasizes the pressure American policies exert on third parties in other countries. However one looks at it, the shadow of the United States has loomed large in Cuba now for well over a century, and it will continue this way for the foreseeable future.

In a sociologically rich history of Cuba in the twentieth century, Pérez-Stable (1999) identifies two ideological projects running through the course of domestic politics since the nineteenth century: national sovereignty and social justice. In the first case, national sovereignty had been thwarted by Spanish colonial rule precluding Cuba's inhabitants, creoles and transplanted African slaves alike, from effectively determining their own destiny. Following a hard-won emancipation for the slave laborers, and two wars of independence spanning three decades, this struggle for full sovereignty continued in the form of resistance to economic and political dominance by the United States, which had entered the conflict on Cuba's side at the last moment as Spanish forces were on the brink of defeat. During the U.S. occupation, the incipient Cuban government was forced to adopt the Platt Amendment as an addendum to the country's new constitution. This deal brokered in the U.S. Congress enshrined the right of the United States to intervene, militarily if needed, under a broad, self-assured mandate to protect Cuban independence from internal or external threats. In practice, the Platt Amendment enabled American 
corporations (and, incidentally, organized crime bosses) to protect their business interests in coordination with puppet leaders of the Cuban republic.

Forced on the Cubans ostensibly for their own good, the Platt Amendment made for a kind of humiliation in victory. It became a pretext in the years to follow for American political intervention, including two more military occupations. Even after Franklin Roosevelt formally abrogated Platt in 1933 - following the downfall of the authoritarian regime of Gerardo Machado and a brief period of effective representative democracy U.S. interests continued to assert influence in Cuba, mainly through lopsided trade agreements and collusion with the primary beneficiaries of such agreements, the island's elite political class.

At the same time, a recurrent notion of social justice played an important role in ushering Cuban society toward a radical leftist project. Colonial rule and, later, U.S. protectionism, consistently produced stark economic disparities on the island and trenchant inequality that generally patterned along urban-rural lines. Under Spain, the slave trade had dominated Cuban history and supplied the labor force necessary for the massive cultivation of sugar cane and the production of raw sugar, the colony's main export to the metropolis and the linchpin of the domestic economy. The first war of independence began, famously, with the defiant uprising of plantation owner Carlos Manuel de Céspedes, who freed his slaves and disavowed allegiance to the Spanish crown. The nominal sovereignty afforded to Cuba after Spain's defeat did not shift the country away from this monoculture or dramatically improve social equity. Rather, the representatives of U.S. interests ensured the survival of the sugar monoculture and the 
unequal structures of trade that were beneficial to foreign sugar barons. By 1920, American investors owned most of the interest in Cuban sugar, and effectively lobbied U.S. political leaders to keep Cuban sugar cheap and import tariffs on American products low. This situation created a trade imbalance that continually kept the Cuban treasury in debt and reinforced the deep division of wealth between the countryside and urban areas, where access to well-paid work and schooling was concentrated.

In theory, trade negotiations with the United States were supposed to provide for mutually beneficial preferential treatment between international partners. Over the course of several deals, for instance, U.S. leaders agreed to purchase a minimum quota of sugar from Cuban sources, while the Cubans agreed to offer favored prices to American buyers, often two to four cents less than prevailing values on the global market. Such deals came at the cost of preventing an effective diversification of the agricultural and manufacturing sectors on the island, making it difficult for Cuban farmers and industrialists to service and saturate their own consumption markets. These agreements culminated in the U.S. Sugar Act of 1956, which provided for Cuba to buy more and more of its rice - the single most important element in the national diet — from American suppliers at reduced tariffs. Such agreements were made over the objections of rice producers on the island, who had struggled to establish a robust domestic market for this staple food even as more and more fertile land was turned over to sugar cane cultivation. Local farmers were desperate for investment funds, but the national banks, in the hands of an oligarchy tied to U.S. interests, declined to support them. As such, Pérez-Stable (1999: 26) writes, "the state failed to promote national interests." 
Pérez-Stable critiques two simplistic readings of the "old Cuba" and of what led to the revolution of the late 1950 s. One view has it that the country was continually on the cusp of an economic boom and full modernization but failed to "take off" because of government corruption and a protracted failure of the rule of law. Here, the causal factors of the revolution are taken to be primarily "political" and internal, in the sense that Cuban elites found themselves too factionalized to agree on a proper balance of governmental power. Members of the middle class consequently enjoyed relatively high standards of living as measured by income, infant mortality, life expectancy, literacy, etc., but felt thwarted in their desire to participate effectively in governance in a way that could guarantee their own civic freedoms on the one hand and the legitimate use of public funds for the public good on the other. This view accordingly posits that the revolution was an essentially middle-class phenomenon, funded in large part by disaffected members of the bourgeoisie; in this view, the strain of national sentiment oriented toward social justice is for the most part ignored. This version of the old Cuba consequently fails to adequately explain the welcoming of radical social transformation on the island after 1959, casting the turn to state socialism and the one-party system largely as the brainchild of an egomaniacal and opportunistic Fidel Castro.

The second prevailing view on the origins of the revolution follows a classical Marxist paradigm that asserts the "structural inevitability" of radical transformation. Here, Castro and rebel forces are understood as instruments in a rebellion that was driven by peasant and working-class interests fundamentally opposed to the ills of capitalism and U.S. imperialism. This perspective emphasizes how economic conditions enabled 
social transformation, doing a better job of recognizing the depth and political significance of inequality in Cuba. But there are two major problems with this view. It is historically anachronistic, for one. This structural-economic account largely ignores, for example, the reformist agenda of many key groups allied with the Rebel Army, and the broad support that this agenda had enjoyed, even in the first months following Batista's self-imposed exile. Until this time, the general consensus in the movement was, upon victory, to implement the 1940 constitution, a progressive document that called for limitations on foreign investments and significant but relatively modest agrarian reform; in no way did this constitution, which was never fully implemented, presage a MarxistLeninist socialist state. Furthermore, the structural account is teleological, assuming as it does a historical endpoint to Cuba's crisis of political authority and reproducing in the process a fallacy inherent in all historical-materialist approaches to social change.

Pérez-Stable and other historians have ably reconciled and complicated these alternative views on the course and character of the Cuban Revolution, building an effective rubric for interpreting the revolution's historical unfolding as well as its institutionalization. At the same time, their history fits nicely the political-economic framework that I have adopted in this work as my own approach to interpreting the everyday context of contemporary socialism. A culturally sensitive rendering of history, much like careful ethnography, disavows neither the agency of structurally empowered social actors nor the socioeconomic conditions resulting from the deeper circumstances of history. Such renderings especially appreciate the contingency of events within structural constraints, reminding us that particular histories could always have been 
different, even if the actual outcomes of historical transformations are never unbounded from prior realities or infinitely variable.

The years leading up to and following the overthrow of the Batista regime offer a telling example of the interplay between social conditions and the contingencies of historical events. Having previously run the government through a series of puppet administrations in the 1930s, Batista undertook an overt military coup in March 1952. The Auténtico Party in power at the time had so mismanaged its authority that the coup took place with virtually no organized resistance, and the conceit of "representative democracy passed away ingloriously" (Pérez-Stable 1999: 52). Batista canceled the coming elections, short-circuiting in the process the career of a young lawyer who had been expected to win the congressional seat in his Havana district, a man by the name of Fidel Castro Ruz. Then a member of the opposition Ortodoxo Party, Castro was deeply embittered with the coup and the following year helped organize a hapless assault on the Moncada military barracks in Santiago de Cuba, together with other young activists in the party. The assault, on July 26, 1953, involved one-hundred sixty-five insurgents and failed miserably, resulting in the capture, torture and death of dozens, and the trial of Fidel Castro on charges of treason. He defended himself in court and captivated the country in a famous speech, declaring: "History will absolve me!"

The July 26th Movement was born. Castro went to prison as a convicted traitor, but was the hero of M-26-7 (as the movement was known). The Batista regime, assured of having consolidated its power, held elections in 1954 in which opposing groups all boycotted and the general ran unopposed. The following year, claiming full legitimacy 
for his regime, Batista reconvened the Cuban Congress and freed political prisoners, including Fidel Castro, a move that was as much a show of confidence as a gesture of goodwill. At the same time, the government continued spending lavishly on public works, doling out contracts to Batista supporters in which more than half of the costs went directly to private profits. Likewise, state banks favored business interests loyal to Batista, denying loans out of hand to any who openly stood in his way. The major trade unions had become compliant with the regime and tended to accommodate it in return for small concessions. Meanwhile, American interests on the island, including crime families involved in the hotel and casino industry, actively supported the president. This was, in short, political life as usual in the old Cuba, with the government growing only more intransigent in the face of public resentment.

In the year after his release from prison, Castro departed to Mexico disenchanted with the possibility of political reformation and reasserting the need for armed struggle. The July 26th Movement issued a statement in August 1955 identifying the existence of a "Cuban Revolution" for the first time. The statement linked the movement to José Martí — that great poet, statesman and fallen hero of the second war of independence invoking implicitly the stalled efforts for full sovereignty and democracy dating back to the late nineteenth century. Meanwhile, Fidel Castro and his brother, Raúl, with the help of Ernesto "Che" Guevara, were gathering together the small band of militants who would head the Rebel Army. At the close of 1956, Fidel and eighty-one other fighters traversed the Caribbean in a yacht called Granma, purchased from an American businessman who had named the vessel after his grandmother. Only a handful survived a 
first confrontation with government forces and escaped to the Sierra Maestra, but from this perch Castro and his followers coordinated a demoralizing war against the Batista regime. Making use of clandestine radio broadcasts picked up across the island and joining in solidarity with insurgent forces holed up in the western mountains, the rebels nurtured their own mystique and capitalized on widespread resentment against the government's repressive tactics. The conflict was carried out largely by hit-and-run attacks against military installations, but was supported in the cities with covert antigovernment actions organized by members of the July 26th Movement as well as other urban groups, such as the Student Revolutionary Directorate.

With a charismatic style of leadership, Fidel emerged as the undisputed commander in chief of the rebellion. Indeed, the key to the movement's victory was not so much military as moral and psychological. The rebels won by surviving long enough to resist the regular army while the latter was still under Batista's sway. Meanwhile, the United States never committed material support for the revolutionaries, or for that matter to the more moderate political opposition. It did however abandon Batista, who had grown so unpopular that the Eisenhower administration approved an arms embargo against his government. The order was issued as a direct response to the widely reported use of torture and political assassinations. But the general refused to give up power, intensifying violent recriminations instead. By the end of 1958 it was clear Batista had lost practically all support from the Cuban people. On New Year's Eve, he fled the island for exile in the Dominican Republic. 
The Cuban revolution had triumphed. The next day, Fidel Castro appeared at Céspedes Park in Santiago de Cuba. In a characteristic hyperbolic speech he proclaimed:

This time, fortunately for Cuba, the revolution will truly come to power. It will not be like in '95 when the Americans came and took over. [...] It will not be like in '33 when the people started to believe a revolution was in the making, and Mr. Batista came, betrayed the revolution, took power and set up a dictatorship [...]. It will not be like in '44, the year the crowds lit up believing that the people had come to power at last, and instead the ones who took power were thieves. No thieves, no traitors, no interventionists. This time the revolution is for real! (Castro 1959)

From the beginning, the revolution appealed to explicitly moral, sentimental and idealistic arguments about the dignity of humankind and the value of collective wellbeing, aspects of the Cuban struggle for generations. These arguments gained legitimacy early on because of real radical social transformation made possible by the popular support for the rebels and the euphoria that their victory generated across class, religious belief, and race. The only obvious losers in these initial stages were large plantation holders, the elite political class made of Batista cronies, and foreign investors who stood to lose a substantial grip on the Cuban economy, one stamped for so long by a trade imbalance that served their interests.

In rapid succession, the agrarian land was redistributed in a way that did not hurt the vast majority of small farmers; wages were aligned more equitably, transferring wealth from factory and mill owners to workers, through profit-sharing mechanisms adopted by decree; and legions of well-educated young people were mobilized to fan out across rural 
areas in what was by all accounts a hugely successful literacy campaign. These developments had popular support but were viewed with suspicion from outside as the Cold War was reaching its zenith. Rumors spread — thanks in part to a CIA propaganda operation - that the new regime was going to take children away from their parents to indoctrinate them in military schools, or that it was going to displace professional families from the nice homes they had built outside of downtown Havana (neither ever took place). This situation was not helped by the adoption of press restrictions or the summary trials and executions that marred the rebel's first exercise of state power, which they wielded often arbitrarily in an attempt to quickly rid the turbulent political landscape of Batista's most dangerous supporters.

Middle-class Cubans had supported the rebellion over the years, morally and financially. But many of them soon began taking flights to Miami and elsewhere in the United States, with plans for indefinite stays. These journeys almost invariably turned into a lifetime of diaspora. In five years, more than 250,000 people had left the island, taking advantage of preferential U.S. immigration policies that remain largely in place to this day (Pérez 1986). Indeed, this remains a key feature of the social landscape in Cuba. Living just ninety miles from the United States, and surrounded by water, Cubans often chose to leave in the face of economic and political disillusionment. The post-1959 exile wave continued at an annual average of 46,000 for thirteen years, before temporarily abating. Successive waves of immigration would follow the ebb and flow of political culture still to unfold in the decades to come: the 1980 Mariel boatlift $(125,000$ immigrants); the rafter crisis of 1994 (35,000 immigrants); and now a more or less steady 
stream of 25,000 a year selected through a lottery process or smuggled across the sea in illicit human trafficking operations.

A commonplace narrative among exiles about the Cuban Revolution is that Fidel Castro "tricked" everyone, in a kind of political bait and switch. Never mind that this perspective unwittingly elevates Castro's personal agency, the real problem with such a simplistic view is that it is not supported in the nuanced historiography of the Revolution that has emerged over time. This history suggests that contingent circumstances made Fidel's authority possible and reinforced, in a kind of feedback loop, the effect of his personal charisma and the real sense of connection he has maintained with the underprivileged masses. From its inception, M-26 and the Rebel Army did not espouse a simple reformist agenda. Fidel had underscored, in his statement to the court, support for the unfulfilled principles of the 1940 constitution, but he also called for much of what would come to pass in the heady days after the revolutionary victory: the redistribution of large landholdings, profit-sharing labor contracts in major industries, and the confiscation of corporate property misappropriated from the public at the hands of corrupt governments. His speech praised the working class, intellectuals and (indeed) small business owners, but left out of its definition of "the Cuban people" mill owners, large landowners and major capitalist interests (Pérez-Stable 1999: 59). By these standards, the revolution made good on precisely what it had promised.

Even then, things might have turned out differently. The steadfast refusal of the United States to accommodate significant social change in Cuba along with the Soviet Union's interests in taking advantage of the situation greatly influenced the course of 
events. The American debacle in the Bay of Pigs Invasion - a plan conceived by President Eisenhower and Vice-President Nixon and carried out under the Kennedy administration — further radicalized nationalist sentiment and empowered Castro to push through more reforms. Not two years later, the Cuban Missile Crisis allowed Fidel to showcase once more his resolve in the face of U.S. threats. For that matter, he demonstrated that Cuba would not be a puppet for its new ally either; Khrushchev removed the Soviet Union's nuclear warheads from the island over Castro's objections. The Castro brothers consolidated political power but did so largely by appeal to the Cuban masses and by symbolizing the end of interventionism in domestic affairs. State elections had produced highly dubious results in the old Cuba, and so their suspension, along with the new regime's very explicit skepticism about the formal procedures of Western liberal, representative democracy, in this context made sense to many people. Immediately after the failed Bay of Pigs invasion (or the Battle of Playa Girón, as it is known in Cuba) the rally cry of the revolution shifted notably from "liberty or death," which echoed Patrick Henry and the anticolonial revolutionary history of the Americas as a whole, to "country [patria] or death!" — reflecting an increasingly nationalistic rhetoric. National sovereignty was to be the political trope of the movement. Socially and economically, this meant the dissolution of an earlier notion of "humanism" as the overt ideology of the revolution in favor of Marxism-Leninism and, consequentially, an allegiance of convenience with the Soviets. This more than anything was the crucial shift in thinking among revolutionary leaders, owing much to the intellectual force of Che Guevara (Dalton 1993). With tension already mounting in advance of the attempt by 
CIA-trained Cuban exiles to take the beach at Girón, Castro had declared before cheering throngs, only three days earlier, on April 16, 1961, that the revolution was and always would be socialist in character. Realizing the United States might be drawn into an all-out war in Cuba and, by proxy, a war with the Soviet Union, Kennedy backed off on providing air support to the invading force, and the conflict was short-lived.

All vestiges of the Platt Amendment had disappeared. The revolution was becoming the Revolution. But as Pérez-Stable argues, the politics of the regime would not become fully institutionalized until the early 1970s. In the first decade of social transformation there was in fact much vigorous debate about the tenor and substance of the changes now underway. Several cycles of "reform and retrenchment" marked the development of a new political economy, and shaped new forms of subjectivity in the process.

These cycles in retrospect patterned with the relative influence over time of two separate political camps in socialist Cuba. One operated on a classically Marxist logic, holding that to transform personal relations the state first had to transform relations of production from the bottom up, following the evolutionary telos of capitalism to communism and the logic that infrastructure dictates superstructure. In practice, interestingly, this camp has represented a relatively moderate, reformist position, because it essentially holds that capitalism cannot simply be swept away overnight. Instead, existing modes of production — sugar is a good case in point — needed to be brought under national control gradually, while workers across all economic sectors needed to be encouraged with material as well as moral incentives. Proponents of this view tend to support systems of "self-financing" in the economy, with state firms competing for 
resource allocation. In this vein, state enterprises were generally expected to generate sufficient profit margins from their commercial practices such that they keep themselves in business. Planning in this orthodox model remains relatively decentralized.

Guevara, appointed as the Revolution's first finance minister, promoted the alternative, more radical paradigm. His camp held that a socialist revolution began with building conciencia (Dalton 1993). Significantly, this is a word that in Spanish conjoins two meanings that in English are always denoted in two separate words: "consciousness" and "conscience." In an effort to build conciencia, in the dual senses of awareness and of moral righteousness, this model stressed ideological education and control over the media. It was also uncompromising about eradicating, out of hand, the capitalist "law of value" rooted in supply-and-demand theory, and in abolishing free markets. Moral incentives were to provide the pathway to communism, while material incentives were viewed with suspicion. Guevara famously proclaimed that Cuba could produce a New Man whose work and life ethic would be dedicated to the common good, equal parts creative, productive and selfless. This view correlated in practice with efforts to centralize economic planning, following a logic of "budgetary financing" in which the goal of enterprise managers was to adhere to the plan irrespective of profitability in any particular sector. Development would proceed along a vision that society, through the state, would set for itself.

In this light, it is clear that the history of the Revolution largely turns on the question of which of these views found itself in ascendancy at a given moment. Pérez-Stable argues that in the early years the two camps were influential in different sectors, as their 
supporters vied for prominence on the political landscape. The self-financing approach took hold in agriculture, for instance, while the budgetary approach took root in the heavy industries. By the end of the late 1960s, however, the emphasis on conciencia and moral dedication to the Revolution had the momentum. Mass mobilizations were the order of the day, and a period of repression and control in the expressive arts was inaugurated this would later come to be known as the Gray Five Years (for an especially cogent analysis of this era, see Guerra 2012).

This radical position gained ground as the economy was floundering. Following a self-financing model, the state had not managed to diversify agricultural production and wean Cuba off of sugar as first envisioned. An attempt had been made to grow the sugar economy in an effort to fill the national treasury, while rebalancing the island's trade deficit at the same time. It proved too much to accomplish in a short period and failed along with the reformist model. In place, the Che-inspired ideology of conciencia filled the void. But much of this fervor was directed, paradoxically, toward salvaging the sugar monoculture. Students, professionals, intellectuals, working-class people and members of the political elite alike were exhorted to do voluntary work in the cane fields in a monumental effort to surpass ten million tons of raw sugar production, the infamous cifra of 1970 - an unprecedented goal. Meanwhile, small business was clamped for the first time in what was called the Revolutionary Offensive. The regime banned selfemployment by decree in 1968 , even though the state had large contracts with many private enterprises and controlled just 25 percent of retail sales. Indeed, of the 58,000 small businesses nationalized at the time, as many as half had been founded after the 
revolutionary victory. All told, they had employed about 300,000 people (Pérez-Stable 1999: 116-188; Triana Cordoví 2012).

When the 1970 sugar harvest fell far short of the sacred cifra, Fidel Castro admitted defeat and acknowledged publicly that conciencia alone could not transform Cuba's macro-economic conditions, besieged as the Revolution was by U.S. economic sanctions and its own unreasonable expectations.

By then, Che had been killed in the mountains of Bolivia on another revolutionary expedition. State economic policy returned to the more orthodox self-financing model under the Economic Management and Planning System (or SDPE, by its initials in Spanish). This system gave managers more leeway to hire, fire and discipline workers while reemphasizing financial incentives. Peasant markets reopened across the island, and in 1978 some forms of self-employment were once again legalized, albeit in limited form. Now fully organized as the country's central political apparatus, the Communist Party experimented with greater involvement of ordinary citizens in social development. At this time, the Revolution was fully institutionalized into a hierarchical apparatus of ministries and agencies responsive to the so-called Organs of the People's Power. The constitution of 1976 had formalized this new political system, vesting legislative power in a national parliament and delegating lesser authorities to municipal and local assemblies of elected representatives. Even still, the constitution explicitly subjected this power to the defense of socialism, and the party was designated as the ultimate trustee of the state. Members of the government's supreme executive body, the Council of State, 
while formally selected from the National Assembly of the People's Power, were in practice drawn from the party's core membership, the Politburo.

This arrangement created as much frustration as empowerment (Pérez-Stable 1999: 123-126) among the people. Government leaders now had to provide a public "rendering of accounts" in local assemblies on a periodic basis. While allowing for open comment on state action, these renderings largely became rote declarations of faith in the party and complicity in the economic plan. As in socialist Eastern Europe, accounts were often made to balance by way of clever machinations without fulfilling the objectives of economic growth and prosperity envisioned in them. The National Assembly carried on wide-ranging debates on the direction and objectives of socialism, in striking contrast to the political climate of the 1960s, and yet delegates invariably carried out decisions by unanimous consent. Once Fidel had spoken, everyone knew, the discussion was over (Bengelsdorf 1994). And in contemporary Cuba, which finds itself in a similar era of carefully managed economic liberalization, all that has changed in this old format is the name of the Castro serving as head of state.

The process of institutionalization and economic organization under the SDPE lasted through the mid-1980s before giving way to another era of retrenchment. During the Communist Party's congress of 1986, Fidel Castro announced a new program to "rectify errors and negative tendencies" felt to have proliferated under the process of institutionalization that had taken place in the prior decade and a half. By now the vast majority of Cubans had been born after the revolution. And though the fervor of those days were close enough in time to have made a lasting impression on the social 
landscape, it seemed clear among the original revolutionaries, who for the most part remained in power, that the time had come for revitalizing the conciencia model. The party reasserted its centrality in political affairs and curbed moderate market reforms as well as the self-financing initiated under the management-and-planning system. Where profitability models had fallen short, mass mobilizations and volunteer work were again promoted as tools for boosting moral engagement in the effort to improve efficiency and productivity.

Historians of the Revolution have identified a number of factors that gave this move its logic. The same year the period of rectification was inaugurated, the state released an action plan critiquing the SPDE. The report found that a capitalist ethos of "economism" had become "pervasive" in state enterprises (Cuba 1986; cf. Pérez-Stable 1999: 156). Workers had fallen under the spell of "personal gain," many receiving full pay for working half-time, spending their afternoons engaged in illicit or marginally legal private enterprise. Budgets did not add up and were too often fudged, the report also said. For example, with greater local control, managers could simply inflate prices to meet production-value forecasts. Decentralization had also made possible unusually large salaries in those sectors that were most successful, inviting the kind of social inequality inimical to the construction of communism.

But there were international factors as well. Sugar prices had collapsed even as the dollar was losing value on the world market. In other countries, this strengthened their foreign trade position. But in Cuba the effect was neutral or negative, because the state could not do business with U.S. companies. Much to the contrary, under the Reagan 
administration the United States hardened its economic sanctions. The Cuban economy meanwhile had grown increasingly dependent on the Soviet bloc for oil, manufactured goods and preferential sugar prices. As a result it now faced trade deficits not unlike those that had prevailed in the worst days of the neocolonial period. Cuba was beginning to pay the price for its pathway of socialist dependency.

Rectification was explicitly called forth to improve economic efficiency in an era of turbulence by appeal to the abstract ideals of socialism. It represented in this sense exactly the inverse choice that Soviet leaders were making at the time under Mikhail Gorbachev's perestroika and glasnost. But as Pérez-Stable argues, the political ideology of conciencia translated in practice into more coercion and social control. In the rectification regime, labor discipline would be more strictly enforced to counteract the "negative tendencies" endemic in state enterprises. Party leaders read any efforts to work outside the plan as theft, "indiscipline," and immorality. Conciencia in this view could only be fostered by stamping out such practices — and certainly not by considering them as, perhaps, part and parcel of the long-term success of building a socialist consciousness. It should be no surprise, given the contradictions inherent in this seesawing approach to state socialism, that the rectification was short-lived. With the breakup of the U.S.S.R. in 1991, the true costs of dependency came due. Thrown into an economic tailspin, the state was forced to adopt emergency reforms under the banner of the "Special Period," as I have already outlined in the introduction.

The crucial point here is that whether in times of relative openness or relative radicalization, the Revolution has maintained a patriarchal hold on power, assuming for 
itself the moral charge of promoting collectivism, while consistently undermining smallscale collective action and solidarity in everyday life. Even the labor unions, erstwhile bulwarks of the socialist project, gradually lost political influence, starting in the 1960s. Subsumed as state agencies, by the '70s unions had ceased to exist all but in name. Guevara himself, before leaving Cuba for his final journey, had insisted that worker strikes were meaningless and therefore forbidden in a socialist system, since all sectors had to function in lockstep toward the singular goal of social development. Sounding an oddly capitalist note, and certainly a modernist one, Che had declared that what mattered most for the country as a whole was production, irrespective of this or that localized disturbance. It is indeed a great paradox of the Revolution, especially in its orthodox mode, that it has not adequately addressed popular grievances. Rather, institutionalization made it increasingly difficult to articulate legitimate, sympathetic complaints in anything resembling an oppositional fashion - the very discourse of "revolution" had been coopted in the process of institutionalizing the system, one demanding full allegiance to the ideological triumvirate of patria-Revolución-Fidel (Pérez-Stable 1999: 105-107). A system of political patronage with roots as deep as the old Cuba — now mocked in the clever pun sociolismo (literally, "buddyism") — ensured that while the managers of state enterprises were also "workers," of equal moral and juridical status to everyone else, their interests would often be at odds with the people they supervised.

The discursive reality of state socialism, meanwhile, makes plain that for all its emphasis on producing a New Man, it relies on many of the same Western concepts of the individual as the seat of consciousness and the possessor of his own person; the 
naturalness of material self-interest; and an unbridled faith in massive productivity, technocratic efficiency and technological advancement in the service of "social progress" through ever higher standards of living. In short, high modernism. To the extent that material self-interest and personal gain are contrary to communism, they must be "overcome" through "struggle" and the development of "conscience"; culture must triumph over nature, and in so doing alter the natural structures in which people live their lives. Capitalism and socialism in this sense are two sides of a common coin, in their ideological premises as much as their actually existing forms. Even though they aspire to different worlds, they imagine as their starting point the same human substance.

Further below, I illustrate this claim in an analysis of two alternative descriptions of the farmers markets established in Cuba in the Special Period. But it is worth mentioning, briefly, that one need go no further than the words of el comandante himself, or those of official government documents, to find evidence for the crutch of modernism inherent in state socialism. In commenting on the development of the SDPE at the first congress of the Communist Party in 1975, Fidel Castro told fellow members of the central committee that moral and material incentives would have to go hand-in-hand. In contrasting socialism and capitalism, he suggested that the base material conditions of life under capitalism could not be guaranteed, a fact that lay at the heart of the capitalist model for growth through labor exploitation. In socialism, by contrast, individuals needed to be provided with moral rewards. These would compensate for those material incentives of capitalism — "the full force, namely, [of] hunger, unemployment and so on" (Castro 1976: 133) — supposed to be missing in socialism. Across different periods in the 
evolution of the Revolution, in speech after speech, Castro in fact relies on comparable mechanistic notions of individual reward as the means by which communism will triumph over the desire for ... individual reward. This same lack of conviction in the "naturalness" of socialism prevailed a decade later, for instance, when the managementand-planning model had fallen in disrepute. Consider this typically dry and verbose excerpt from a review of the government's rectification plan, appearing in a statesanctioned legal journal:

One aspect that has contributed to the debilitation of worker discipline in the last several years is the lack of insistence on achieving the order necessary to complete the product or service, sometimes making it normal to act with indiscipline in some spheres, especially those related to the provision of services. [...] It is important to note that from the beginning of the rectification process in our economic management system, one can observe an improvement in discipline as a result of a most positive change in attitudes regarding work. Exemplars of this are the occupational feats of more than a few labor Contingents, the revival of the vigorous movement of Microbrigades and, in that spirit, the struggle $[l u c h a]$ to fulfill work projects that uphold the social interest in the shortest possible timeframe and with the requisite quality. (Pascual Díaz 1992: 109)

Here, "indiscipline" (a concept I take up more fully in Chapter 4) is conceived as the product of achieving insufficient social order in the workplace. The rectification process, in turn, is credited with helping address this through the spirit of la lucha, implied as the struggle against market-oriented tendencies. In no case is the possibility of a creative human impulse for solidarity considered relevant — or for that matter a potential source of so-called indiscipline. 
None of this, of course, actually stamped out human creativity in everyday life. If anything, the Revolution's history of cycling between reform and retrenchment, all the while emphasizing the ideals of communist solidarity, produced the kind of ambivalent economic invention toward which my research project is oriented. As we shall see, the Cuban people (especially the most disenfranchised) took socialism into their own hands — as genuinely and as best they could.

\section{El Agro: Two Perspectives, One 'Market'}

Before turning in greater detail to the contemporary context, however, it will help to provide some background on the privatization of Cuban agros and Cuatro Caminos in particular. I do this by comparing two recent studies on the topic, each of them from cultural reference points which are in apparent opposition. Along the way, I juxtapose certain ethnographic experiences of my own to clarify the distinctions intended between these texts and my own view of things. The first text is a white paper (Peters 2000) published by the Lexington Institute, a libertarian think tank based in Washington. Peters analyzes the economics of Cuban farmers markets in the context of Special Period reforms. The second is a monograph (Couceiro 2005) on social life at Cuatro Caminos, based on the exploratory fieldwork of the author's students and appearing in an ethnological journal published in Havana by the Fernando Ortiz Foundation. In both cases, I draw on these works as ethnographic sources, but I also offer a critical analysis of their perspectives, which stand as foils to my own. 
My close reading of what little has been published on Cuban agros will demonstrate that, interestingly, writings on the subject both in Cuba and beyond reproduce similar suppositions about market incentives, Cuban history, and state-society relations, ones that do not adequately capture the deeper reality of the social practices that agros have served to enable.

\section{The view from outside}

Peters (2000) identifies farmers markets as the new "hub" of Cuba's burgeoning private sector, where "elements of capitalism" have been injected into a critical arena food production and distribution — previously dominated by the command economy. He gives us what we might call a classic outsider's perspective, one that privileges Western capitalism as the yardstick against which to measure all economic activity.

This is not to say his analysis is unhelpful as a gloss of the agro context. Peters identifies, for one, a suite of reforms significant to the functioning of agros in the present context. As he explains, implementing produce markets in the cuentapropista mode required the Cuban government to simultaneously liberate farming cooperatives and small landholders in the countryside to sell surplus inventories, i.e., everything the state did not buy from them at fixed prices. By the same token, other government measures served to increase demand and create a customer base for the new markets. As Peters notes (and as we saw in the previous chapter), these included the legalization of the dollar and other foreign currencies; the legitimization of other small licensed businesses; increased foreign investments in enterprises where workers might make part of their income in hard currency; and reforms of state enterprises and farming practices to boost 
productivity, including efforts to provide successful workers with bonuses tied to their output.

By the turn of the millennium, the Cuban government had redistributed at least twothirds of public land to peasant cooperatives and families, providing them with tools in exchange for a quota of their produce. These efforts have gone further still in the recent transition of power from Fidel to Raúl Castro, whose first May Day speech as president, delivered in 2008, announced that thousands of acres of fallow land - derided in Cuban popular lore as overgrown with impenetrable weeds - would be turned over to private interests. Like many other Western observers (including journalists and social-science researchers), Peters understands such changes as part of a gradual, natural and thus inevitable transition to capitalism: "Taken together, the impact of these reforms has been to create a hybrid economy where the state dominates, but socialist planning is eroding and market mechanisms are increasingly relied upon" (2000: 3). To be clear, this is not in my view the same notion of hybrid economic moralities as Altman (2009) identifies in employing the same terminology. Rather, it suggests the idea that a "chemically unstable" mix of capitalism and socialism are in play.

In fact, there was nothing particularly new about the opening of agros in the Special Period, except insofar as the circumstances in which it took place were more dire than ever. Already in the 1980s the Cuban government had experimented with market-based produce sales, as we have seen. At the time they were called "free peasant markets." Peasant collectives as well as independent farmers could sell surpluses at prices they negotiated directly with consumers. After just two years, Fidel became uneasy with the 
results of the experiment. In a speech before the state farmers union, he suggested that pre-surplus produce intended for the regulated economy was being diverted to farmers markets, while transporters and retailers were skimming too much of the profits, leading to what is categorized in the authoritative discourse as "illicit personal enrichment." The solution, el comandante insisted, was to ensure that most if not all farmers were working under the umbrella of agricultural cooperatives and state unions rather than operating autonomously. Cuba still received subsidies from the Soviet Union then, and per capita consumption levels of meat, dairy, fruits and vegetables, and fatty oils were well above recommended dietary levels. Acknowledging this history, Peters concludes that this earlier "market shutdown" constituted a retrenchment that the state could at that juncture afford.

Yet my research participants remembered that in the 1990s, despite the drop in subsidies, there was a new kind of wealth. The influx of U.S. dollars from increased remissions and the growing tourist sector left a large percentage of the urban population flush with cash while having little to spend it on. Despite their awareness of this quandary, party leaders apparently did not have the wherewithal to organize food surpluses for the urban population, or to transfer much of that foreign-currency income to farmers, who were as a matter of course among the least likely to earn any of it on their own. Rumor had it that fresh food was going bad in the countryside while people in the cities went gaunt on one meal a day, consisting at times simply of a sandwich with mayonnaise and nothing else. "Forget it," many city residents told me in reference to 
such experiences. This was the exasperated lead-in to a scripted phrase that went: "Come on. If we could have eaten these dollars we would have."

Indeed, my friends in Havana took dark pleasure in recounting the extremes to which they developed, by way of invento, creative responses to the dilemmas of the early Special Period. One story I heard many times and in many forms is worth recounting here, as it speaks both to the lack of available food and the tendency for informal business practices to recodify what constituted normal, everyday, socialist practice. This urban legend held that a group of unlicensed food vendors set up a street stand in a central part of Havana with all the appearances of a sanctioned business. They sold a kind of sandwich called pan con picadillo (bread with ground beef). This was roughly the equivalent of a sloppy joe, served on stale slices of Cuban bread. Privately, these desperate entrepreneurs called their products "socialist sandwiches." They concocted imitation beef from cotton rags commonly used for mopping floors, a standard-issue variety available at the state's general stores and sold to households in Cuban pesos for subsidized prices. One vendor at Cuatro Caminos dramatized the production process for me with particular gusto, alternately waving his hands and clapping as he spoke:

You had to know someone who worked at a bodega [a state-run ration shop] who could get you plenty of rags. Then you had to shred up the rags [these were made of a threadbare, pulpy, cream-colored cotton] and soak them, for about a week, in pork's blood you got from a friend who worked in a state butchery or a slaughter house. So the blood soaked into the cotton, coagulated, and added a nice flavor to the pulp. Then you could mash it together, cut it in patties and fry the patties like meat. Slap them on the bread, just like that. They sold a lot of them, this one family. Until the police discovered 
what was going on and arrested all of them for operating an illegal enterprise. Which was unfortunate, people said, because those sandwiches didn't taste that bad.

It hardly matters whether stories like this were actually true. The key point is what these stories, and other forms of dark humor, meant to the people who circulated them: Cubans welcomed the reopening of agros in the 1990s and were ready to make of it what they wished - within, as always, certain constraints.

The legal constraints on new agro activities were articulated in regulations issued in 1994. The rules called for "market prices" at the agros, allowing for produce to come from virtually any source: cooperative farmers, small landholders and state enterprises themselves. Vendors could apply to operate stalls at the markets, where they would be required to pay a daily tax on their activities and a fee for the space made available to them. The regulations also provided for penalties if vendors or producers violated the rules, for example, if a farmer's products reached the agro before he failed to meet his state quota. The marketplaces themselves would be situated in accordance with the wishes of local officials, and state employees would work as inspectors, tax collectors and consumer advocates at each location.

The response, as Peters describes it, "was dramatic" (2000: 5). The agros sold some 390 million pounds of produce in their first calendar year of operation. For Peters, "the farmers markets immediately undercut black market prices," which dropped in Havana some 75, 50 and 14 percent for rice, pork and beans, respectively, the main ingredients in many a Cuban supper. Sales at farmers markets tripled in the four years following the initial burst, and more than three hundred agros had opened across the island by the end 
of 2000. About half of the sales were concentrated in Havana, frequented at the time of Peters's study by no less than one fifth of city residents. Despite these results, there was during the time of my fieldwork, no shortage of complaints about Havana's fifty or so produce markets: expensive, expensive, expensive, people said. But where else are we going to find green peppers and bay leaves? "The state doesn't give them to you anymore — that's for sure," was the typical refrain.

In the past decade the regulations on farmers markets have been modified from time to time. Some markets have been nationalized and then reprivatized, and the largest agros face constant if irregular threats of crackdown from commerce inspectors. Nevertheless, the reopening of farmers markets this time around has had staying power. Agros have provided a critical avenue for putting food on the table and, in the process, a new site for rethinking Cuban subjectivity. Behind the seemingly separate peso world of the agro, with its beans and lettuce and mangos, you could buy Marlboros or place bets in the local numbers game, pegged to the results of Florida lottery.

But the complexities of this activity adhering to agros is not clearly theorized in the scholarly or popular literature. For Peters, it seems as if free market principles operate openly, if only in a limited area, and in a space dominated by the Cuban peso. This made it accessible to many Cubans, but kept such nascent "free enterprise" completely within "the Cuban system" and delimited by it. My analysis, in contrast, will suggest that orthodox market principles did not hold in any simple way, nor was there a sharp boundary marking agro activities as operating "within" the system as opposed to other, 
more marginal cuentapropista activities. Instead, the system can be seen as engendered through the everyday action and exchanges taking place at farmers markets.

Peters himself points out that the mere fact that independent vendors were permitted in this second state experiment with farmers markets was significant. In the 1980s version, farmers had to sell produce directly to consumers, requiring them to travel great distances every day. In fact, this never really happened, and the government's annoyance with such rules being consistently broken contributed to the decision to close the peasant markets. This time around, the rules allowed vendors to "represent" particular farmers, legalizing what had before happened in practice. Even then, however, market workers bent the rules further to suit the particular practices they deemed necessary for survival. Rather than hire representatives, farmers regularly paid transporters with their own cars and trucks to move agricultural goods for them, and transporters would resell their produce at markets around the city. This whole procedure took place practically every day, between 2 and 6 a.m., so that produce could be laid out on marketplace stands by the time the agro opened for business.

These intermediary steps were further elaborated at major agros. There, vendors behind any particular stand were almost always day-laborers. They earned a fixed income, usually between fifty and sixty pesos a day, to sell produce that belonged to a broker who bought in bulk off the haulers' trucks. They often referred to the broker as "the owner" of the tarima, but usually vendors themselves acted as owners in the investor's absence, sometimes paying the daily tax (declaración) from their own pockets, or through a combination of their own money and the owner's. As we shall see in the 
next chapter, they regularly shorted either their customers, through slight decreases in the weight of items sold by the pound, or the owner himself, by underreporting sales at the end of the day or the week, depending on his or her method of accounting. Peters notes, and I too witnessed, the existence of some big bosses who "owned" or oversaw - that is, held an actual or de facto license - to several stands, sometimes located at more than one market, and shuffled between them, moving around produce from storage areas on site and in their homes and supervising their workers. Of these shufflers, some were more diligent than others, some were practically absentee owners, while still others appointed further intermediaries, say, a younger family member, to stand in their place. But more often than not, "owners" at Cuatro Caminos worked alongside their workers and maintained a cordial relationship, sharing with them the risks of the business and the entailments of their personal lives. Even though many agro day laborers changed from day to day, certain tarimas at the plaza, in the time when I worked there, had the same workers behind them day in and day out, employees whom the owners said they trusted and vendors whom regular customers recognized.

None of these structural, everyday innovations of the agros were permitted by law, but they all existed in the open. Peters is right in observing that these constituted "a legally ambiguous situation" where specific prohibitions on independent vendors, tarima owners and haulers were barely enforced. The prohibitions had to exist, he suggests, because private enterprise was such a "sensitive ideological issue" for the state, while the intermediary sales and labor practices materialized as a "natural attribute" of markets. 
Peters quotes an unnamed Cuban official as saying, "There may be things we don't like, but we have to recognize that the markets have to function" (2000: 8).

This suggests that official discourse about agros also reproduced capitalist assumptions about the "nature" of the market. My contention, however, is that inventomarket actors generally did not see their activities as a product of natural drives but a direct result of their own creative, and collective, action. Peters assumes that, because illegal activities took place more or less openly, this was a case of toothless prohibitions that went unenforced. The agro workers themselves, however, took the possibility of sanctions seriously, while also recognizing that their own agency produced an ad hoc enforcement of, and a gradual alteration of, the rules themselves.

Recognizing this situation leads to an alternative understanding of certain events in the agro movement of the last two decades. For example, when authorities said through various official channels in 1998 that official rules pertaining to agros would now be enforced by the book, as Peters writes, "vendors withdrew from the markets" in a form of silent protest. He suggests they returned the following year "when it became clear that this enforcement would not proceed." Of the vendors and owners who remembered that time, most told me their return was more a matter of "things cooling down." They had a sense now of how the rules would operate and could maneuver within this new normal. In the next chapter, I offer several examples of events at Cuatro Caminos that took place amid government raids on the plaza toward the end of my fieldwork, to suggest how two forms of experiencing the state are produced in everyday life. 


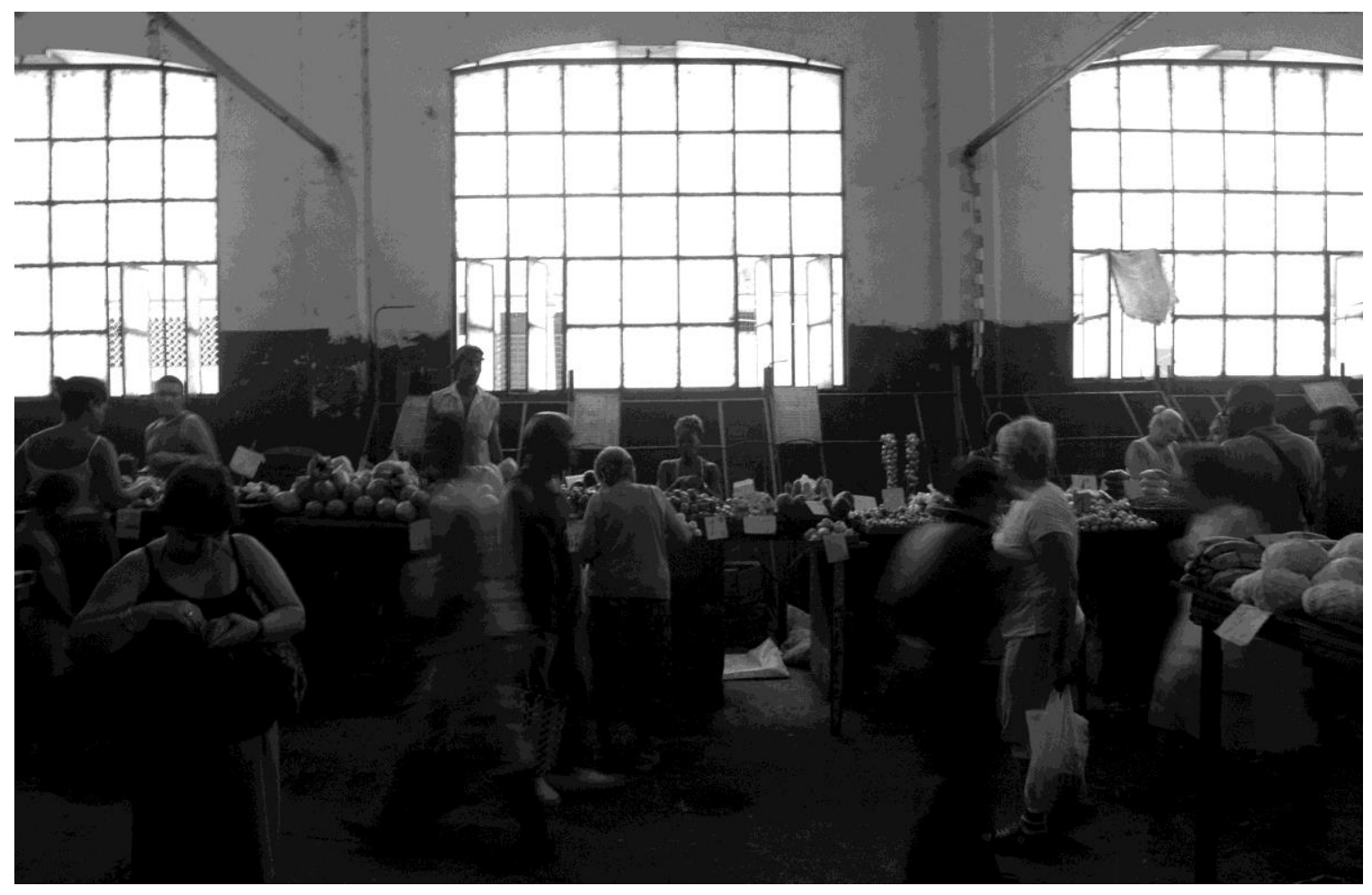

\section{PHOTOGRAPH 2.3}

Cuatro Caminos, view of the produce stalls.

\section{The view from inside}

Now, however, I turn my analysis to an inside perspective of the market. In a monograph entitled "El mercado tiene cuatro caminos" (the market has four routes), Couceiro (2005) compiles and comments on ethnographic data collected by anthropology and sociology students in one of his courses at the University of Havana. That I know of, it is the only published study on contemporary life at the plaza. But this text is also notable for transcending, in part, a general problem of anthropological research in Cuba today. Most ethnological research in Cuba is largely concerned with the past, or with looking at marked ethnic groups and migrations to Cuba (e.g., the African and Chinese 
diasporas). That work tends to foreground Fernando Ortiz as the patriarch of anthropology in Cuba, glorifying his work and that of his students without much attention to the development of the discipline as a whole. With only a few key articles in other issues of Catauro doing anything like it, Couceiro and his pupils turn the lens on certain touchy realities of everyday life, applying ethnographic methods to contemporary social settings.

Though it is not widely circulated, Catauro is available at some state bookstores in Havana. It has the imprimatur of an academic organization funded and sanctioned by the state. In other words, the journal is closely observed even if it operates with a higher level of independence than typical Cuban periodicals. One scholar closely associated with the foundation told me privately, with some bit of dramatization, that the foundation's president "got an earful" from government officials after the publication of the Cuatro Caminos monograph, and several others like it. Considering how carefully circumscribed this article seems to be, mainly reflecting on facts about the plaza with which Havana residents would already be quite familiar, and falling well within what I think of as the "ideological safe space" of recent Cuban academic discourse, that such work is controversial at all is telling. It reveals the sensitivity with which career academics and the state agencies supervising them regard research about almost any aspect of ordinary life, because such life described as-is, in detail, would inevitably call into question basic assertions the Revolution makes about itself.

In my reading of this essay I hope to foreground some salient aspects of the plaza from the perspective of, in effect, a group of native scholars, but also to treat the essay as 
itself an ethnographic object reflecting how Cubans, and specifically Cuban intellectuals, discursively construct ambiguous relationships to the paternalistic state project, thereby reproducing the project and their role within it.

When situating Cuatro Caminos within the consumptive structure of life in Havana, Couceiro does mention the contradictions of the dual-currency system, but in the process reproduces a view of the peso-CUC distinction as fundamental and clearly articulated, creating real, impermeable boundaries. He is at pains in an extended footnote to dissociate the divisa realm — with its "exclusive," "impersonal" and "narcissistic" tendencies — from the realm of Cuba's moneda nacional. At Cuatro Caminos, food trades in pesos, with the goal of making available basic produce in prices that if not low are far more affordable than the new shopping centers. Unlike the agro, he writes, grocery stores opened to serve the diplomatic corps look and feel like foreign supermarkets, and they operate "in a currency that the common Cuban worker cannot obtain, except by other means outside of state employment, which predominates almost absolutely in Cuba" (2005: 98). Making such a statement, mainly for an audience of other Cubans, seems at once superfluous and also knowingly inaccurate. What is "known to be known," but which cannot be uttered in this public discourse is clear: what really "predominates almost absolutely in Cuba" is not so much state employment, but the personal redirection of state work so as to make a living as best as one can by those "other means," to invoke the author's euphemism.

This is not to say that Couceiro's essay ignores the confluence of multiple social frameworks at Cuatro Caminos. It is for him a site where the capitalist "logic of 
equivalence" penetrates, but one in which that of symbolic exchange defines the ambience. He sets the scene by reference to the range of skin tones and facial features one finds among those moving through and working in the market, and the cacophony of regional speech patterns one hears on a given day. Here, you can find basic produce; at the same time, many practicing Santeros know Cuatro Caminos as the place where they can find the proper flowers and live animals (mainly chickens and quail, sold in separate quarters at the rear of the plaza) for their spiritual rites. At the same time, however, the broader and fundamental duality through which Couceiro reads life at the market allows no more than passing, vague references to certain present-day "ambiguities."

That duality appears distinctly in the author's rendering of the market's history, presented by way of contrast - typical in Cuban scholarship — between what came before and after "the triumph of the Revolution." Before, Couceiro allows, El Mercado Unico was visibly prosperous. It had three floors, all of them in use, including vast refrigeration systems in the basement. The police didn't constrain buying and selling, and even the poorest of vendors could set up makeshift barrows around the edges of the building without danger of prosecution. But poverty was endemic, and the market in those days, in the wide range of quality and prices it offered, reflected deep class divisions. In another footnote, Couceiro hints at these divisions, suggesting the market of the past, abundant though it was, also brought together poor vendors living in "pestilence," delinquents, and beggar children with the household "employees of rich families and the ladies who went in their cars with their drivers to buy the best and most expensive products" (2005: 104). 
In critically reading this history, my objective is not to take issue with the facts presented about the past so much as outline the particular forms, categories and trajectories of the narrative. For example, Couceiro can critique the abject poverty of the past but not that of the present - except to say that Cuatro Caminos today serves even those of "humble means." And yet the plaza's entrances were, while I was there, the common province of many handicapped, mentally ill and indigent men and women. They spent the day lying on concrete benches along the building's outer walls, often in a ruminduced stupor. They slept submerged in an inexorable stench from the neighborhood garbage mound, a few feet away. The trash had been piled up over a municipal trash bin, and spilled out onto the busy corner of Matadero and Calzada del Monte.

Couceiro notes, saying "let's be honest," the deplorable physical condition of the building itself, badly in need of a paint job, its windows blown out, the tiles in the roof cracking precariously. But the homeless, the listless, the beggars, the trash — these warrant only a passing reference. In the end, this brief history of what was once El Mercado Unico is colored with a mix of repressed nostalgia and performative realism. With the re-adaptation of the plaza for use as a socialist-era agro, the author suggests, if obliquely, that the best and worst of Cuba's neocolonial period seem to have gone: "for the youngest of us, who know the past only in tales, this Market presents itself as the ruins of that distant commercial Babel" (2005: 104).

In a similar light, Couceiro notes how there were, before the Revolution, all sorts of "clandestine" activities around the market. Among the contraband he lists gold chains and watches, and gem-studded rings of dubious origin. Similar activities at the present- 
day Cuatro Caminos, meanwhile, are referenced mainly in a series of footnotes, their physical displacement from the central narrative implying that they do not in fact form an integral or, for that matter, integrated part of daily life at the plaza in its latest incarnation. On the other hand, the fact that such activities are mentioned at all in the text, and in such significant detail, is remarkable. The field excerpt cited in footnote 16 is worth quoting at length:

These illegals, of course, do not pay the state fees, as it is for that very reason that they do not make their private "business" official; it's a very heterogeneous group, which includes everything from the person who sells a watch, a chain, cowboy pants, a pair of shoes, to the little old men who sell individual cigarettes, shots of black coffee, candles, plastic bags, and those others who early in the morning come on bicycle with animals for sale, including pigeons mainly for religious ends [...]. These sales take place outside the plaza, and "los de adentro" [the inside people] view them as competition. The illegals get fined, even though treatment of them differs as the case may be. (Couceiro 2005: 106)

Seen from one angle, this kind of work is suggestive and opens the door to further inquiry. In my case, reading about such activities in advance of my fieldwork led me to want to theorize them further and enrich the ethnographic record with my own interviews and participant-observation. (There is no sense in the Catauro essay, however, that the underlying fieldwork involved actually talking to the so-called "illegals"; this was a term used in the plaza, but not one, I learned, that such vendors ever used to refer to themselves). From another angle, the Catauro essay steers readers away from a complete picture of agros and Cuatro Caminos in particular, and its significance for daily life in the Special Period. For instance, Couceiro notes a symbiotic relationship between tarima 
operators and illegals, but dispenses quickly with this interconnection as one produced in the conventional operation of supply-and-demand economics: tarima vendors, he tells us, have the money after all, and they are a captive audience in the market all day and often bored or sleepy (2005: 107). But what (we might ask) do these social actors make of their own relations, and are these categories — the "illegals" vs. the tarima vendors, for one so clear-cut?

The Cuban state is also reified as a unitary category in this scholarly discourse, despite the evidence presented suggesting that a more nuanced view of "the state" as a malleable notion in plaza life might be warranted. For Couceiro the dominance of the state ("el Estado," as he writes, with a capital E) is taken as given, and the subtleties of everyday subjectivity that do not neatly fit this paradigm — as either of the state, or apart from it, or against it — are flattened. We learn that both a worker's union and the Communist Party have formal chapters associated with the market. According to Couceiro, market vendors report "good relations" with these institutions and with plaza managers (employed by the government); they say they feel their interests are "represented and protected," though one admitted that if you don't play by the rules "they kick you out" (2005: 105). Likewise, we learn that state officials keep the bathrooms clean and aromatic; that they provide consumer protection in the form of an electronic scale that customers may use to verify the measures of tarima vendors; and "area chiefs" — state agents overseeing various parts of the market — act effectively as liaisons among customers, inspectors, vendors and the state-appointed market director. The state is given here its "proper" place, helping things run smoothly. 
A more negative view, interestingly, appears in the narrative when the state is associated with "economic" matters. For example, Cuatro Caminos, like most agros in Cuba, had a small percentage of state-run tarimas. In principle, prices are fixed in these areas, and this helps to drive down the cost of produce at other, privately operated, produce stands, located perhaps only a few feet away. The Catauro field team reports that produce from state-run tarimas was never as fresh as the produce available from private vendors even though the difference in price — if there was any — was negligible. Couceiro also insists that the main concern for private vendors was not cost but quality: providing a good experience and catering to regular customers. This is why, he insists, private tarimas are by comparison "perfectly orderly," "give off a good image," frequently offering extra services, such as plastic baggies free with the purchase of a pound or two of dry beans.

The structure of state employment at the plaza also receives negative marks in the essay. While most day workers in privately owned tarimas made fifty pesos a day, a state worker earned forty-five pesos a week, and got no commission based on the stand's revenues. Here, Couceiro is decidedly neoclassical in his economic assessment of the situation: "These working conditions indisputably reduce, if not eliminate, these workers' interest in selling" (2005: 110). What is not examined, however, is how even state workers are integrated in the invento world, a fact I take up further in the next chapter.

And when it comes to dealing with "illegals" in and around the plaza, the Catauro essay portrays the Cuban state yet again as falling short of its ideals. Candidly, the author notes that many businesses crop up around Cuatro Caminos thanks in large part to the 
traffic the market brings to the neighborhood. He views these as "inevitable" results of the system, and acknowledges (without providing specific examples) that many customers go to illegals for items similar to what's available in the market, at cheaper cost and with better service. Attempts by the state to reign in such activity appear ineffective, Couceiro writes. When the local police chief walks through the portico, "the whole dynamic of the market" changes: in a flash, the illegals disperse and the inspectors stop loitering in their usual cheery ways.

In my own analysis of invento, I consider complementary ethnographic material from the plaza. In doing so I will attempt to broaden and complicate Couceiro's interpretation. Rather than understand these practices as apart from or beyond the life of the market, changing its dynamic when they take place, I consider how they are part and parcel of life in the market: regularized renegotiations of state authority in everyday life. Building on some recent but very limited scholarship on cuentapropismo that questions the teleology implicit in the discourse of capitalist "transition" (Phillips 2007), my analysis will also begin to take up the extent to which authoritative discourses themselves enable, through the deployment of nationalist and socialist ideologies, this very reshaping of the terms of what Cubans call "the system."

\section{The Market: Place, Praxis, Idea}

So far I have provided background crucial to understanding the place Cuatro Caminos occupies in Havana, materially and symbolically, and the place of Cuban agros more generally. In doing so I have relied especially on two sources, in addition to some field 
experiences, but I have also tried to critically analyze these sources as ethnographic data. One view is what we might gloss as a conventional U.S. view of Cuban socialism in the Special Period: the state fails in its effort to mediate economic activities, and the implication is that this failure will continue until the state "gets out of the way." The other view appears in an ethnographic monograph written for a Cuban scholarly journal with avant-garde leanings: here the place of the state is more ambiguous, and many of the complex realities of everyday life that might lead to a more nuanced view are not brought to the foreground of the text. Overall, it too reproduces a conventional, commonsense duality between the state and the economy. Here, however, the implication is that the state needs merely to account for "human nature" and do a better job of shaping that nature more carefully toward its utopian goals. While both texts provide sharp (and rare) contemporary descriptions of agros, and (in the second case) the plaza at Cuatro Caminos in particular, they do not transcend the conceptual limitations they share. What is lacking, I suggest, are closer readings of the everyday experiences in question. While I came to this perspective gradually over the course of my fieldwork and post-field analysis, I trace the beginning of this thinking to a certain sweltering summer day.

\section{Rite of passage}

The smell of burning pine wafted up from a fifty-gallon drum where a massive stew simmered. The sounds of reggaetón - Cuban hip hop - blared from crackly speakers, making it hard to carry on a decent conversation. It was Father's Day in 2005, a hot and humid morning in Havana, and I had come to a small farmers market in a claustrophobic corner of the city's old colonial quarter, on the invitation of a new friend. He asked me to 
call him Maestro, and this is how I still think of him: the first teacher to offer me lessons in earnest on the invento market. We had not known each other for very long, but in this short time Maestro introduced me to life in the agro and started to help me see what was going on beneath the surface of things. He understood, if only intuitively, why I was here and what I wanted to get out of the experience: an understanding of everyday life in Havana that went beyond the postcard-ready images of boys leaning on ' 57 Chevys brought to us on the travel pages of The New York Times.

Maestro was actually a state-employed administrator in this market. He was in charge of consumer protection and other various tasks. With about twenty tarimas, the place was tiny by comparison to Cuatro Caminos, which in these early days of my fieldwork I had not yet happened upon. Now in his 50s, Maestro had had a career as a schoolteacher, but retired somewhat frustrated with the work. "The students don't respect you anymore," he said. "It's like a zoo nowadays." The market was not far from his home, about fifteen minutes walking, and he had friends there who were vendors. They told him to come and work here. It was steady employment, would add to what little he received through a paltry pension plus some money from his son and daughter overseas, and it would get him out of the house every day.

For the vendors, it always paid to have a friend on the administrative side. A man who enjoyed drinking heavily, perhaps too heavily, Maestro would bring some cheer to the monotony of the seven-day work week. Though small, this particular agro sat in a busy part of the neighborhood, a section of Old Havana lying rather afield of the tourist areas with their multimillion-dollar renovations, the buildings here dilapidated and prone, 
not infrequently, to collapse. Wrapped at a right angle around a tenement-style apartment complex there was a single corridor about a hundred yards long with stands selling a wide variety of produce, especially considering the small size of the agro. This time of year, there were pork chops, mangos, plantains, cassava root and pineapples. I never had reason to doubt Maestro's insistence that he was well liked. Often he left at the end of the work day with several bags of small gifts, a smattering of the produce left unsold. He brought these home to his wife to supplement their humble dinners, which they took like so many Cubans over the din of a TV set they largely ignored but almost never turned off.

At the Father's day festivities, the music system was loud enough but not in especially great shape. The speakers had strength enough to rattle the corrugated roofs above the tarimas and blanket the market in a booming bass. With some help from a few vendors, Maestro had propped them against the outer wall of the apartment behind him, the wire connecting them dangling in the pitter-patter of a persistent rain. "I arranged for [resolvi $]$ the speakers with a former student who knows about electronic stuff," Maestro told me, not elaborating precisely on this particular use of "resolver." (Many of his erstwhile pupils had become butchers in the market, others were buyers who stopped by to say hello.) In describing the speakers and his part in planning for the feast, Maestro used a Spanish borrowing from English (los espíquers), indexing a kind of laxity to the affair. They weren't great, he admitted, but they were far better than the scratchysounding audio equipment that the government provided for occasional public addresses from the agro's administrative booth, and which often failed to work at all. 
The rain did not stop the revelers. Between sales and stray dogs, they danced with the music and, starting early in the morning, the three dozen men or so who worked in the market took shots of cheap rum from little disposable measuring cups with the logo of Havana Club, a famous national brand, or from the bottoms sliced off of nameless plastic soda bottles. Most Cubans I knew regarded Father's Day, and Mother's Day for that matter, with great seriousness. Every man of age received hugs, handshakes and multiple well wishes as they passed through the market, including me. Indeed it was my first Father's Day, and I was spending it, somewhat gloomily, away from my daughter. She was just shy of 1 , and had stayed home while I set off to Havana in search of a research project. Mentioning this predicament to Maestro was what had prompted an invitation I could not in good conscience refuse. You shouldn't be alone on such a day, he had said to me the week before. Come and celebrate with us. We'll have a good time.

Maestro acted as my self-appointed liaison. It felt as though he introduced me to more people than I usually meet in a year. I followed him around rather like a puppy, and for each new person, most of them workers in the market, he explained who I was, the details of my background growing taller with each telling. By the end of the day, he had awarded me, somewhat prematurely, a Ph.D. In the afternoon they sent Maestro to buy the beer, one bottle for each male worker in the market. Everyone behind a tarima had contributed some of their own money (and probably, I realize now, some of the tarima owners' petty cash, unauthorized) to cover the drinks and the stew of vegetables and pig's brain that would cap off the day. As we will see, this was not an occasion of or for the state, and government funds would not support such an endeavor. The major beer labels in Cuba 
cost one chavito per twelve-ounce can, a price out of reach for all but the most special events. But the beer Maestro's friends sent him to buy — a home brew of some kind, or maybe an off-label variety "resolved" out the back door of a state factory — had been negotiated at half the going rate, payable in moneda nacional, so nothing would be lost in the conversion. I tagged along for the ride.

Unwinding a ball of frayed twine, Maestro tied a length of it around the base of a plastic crate, strapping it to the back of his bicycle. Together we rolled the bike to the house where the beer man lived, turning this way and that down several blocks along narrow, unfamiliar streets whose names I cannot now recall. Along the way I asked Maestro, naively, where the beer man got this mystery brew. Patiently my teacher explained what in retrospect seems obvious: "If this guy told us where he gets the beer, we wouldn't have to buy it from him, see?"

When we arrived to the appointed location, a cinderblock flat up a flight of narrow steps, Maestro knocked and called out, "Pepito!"

Pepito's wife opened the door. She invited us into a spare and dimly lit kitchen, smaller than many closets. Her husband was out — "figuring out [resolviendo] some things" - but she counted out the merchandise on his behalf, pulling each bottle one by one from a massive 1950s General Electric refrigerator. Maestro and I counted out the funds. Only half of the beers are cold, the wife told us. Maestro frowned. It would have to do. I added an extra bottle to the batch, with permission, and paid my share over Maestro's objections: “They'll be enough for you, Robert, don't worry about it!” Before 
we left, with the beer in the crate on the bicycle, in the middle of a crowded street, Maestro slipped a canvas bag over our purchases.

"Why do you do that?" I asked.

"Ah, well," he said. "Because all of this is illegal."

\section{Reciprocity, power, and cubanidad}

This was my introduction to urban farmers markets in Cuba. It has stuck with me over the years and became a touchstone for my thinking about invento. This event carries within it the seeds of many of the issues I take up in the next two chapters of this work. Here, I elaborate on a few of them to underline the premise that there is no universal ideal of "the market," or "the state"; instead, there are only particular experiences of exchange and political power situated in a variety of morally conceptualized arrangements.

To start, Maestro's position in the market, as administrator, friend and elder to the vendors whom he oversaw, suggests how the practice of state power is integrated with everyday life in complex ways. He was not simply the mindless agent of a power far greater than himself, nor openly resistant to its purportedly oppressive tactics, but an active participant in the context-specific formation of the state, which is to say, its realization as a thing believed to exist and therefore impossible to ignore, while at the same time a thing believed to be negotiable and flexible - at once a limitation on one's activity and a resource for meaningful action.

Furthermore, the mechanism by which this integration of state power and everyday life took place often involved a particular kind of economy, one in fact associated with socialism in an ideal sense, but not generally understood, at the level of either 
administrative structure or technique, as fundamental to the workings of a MarxistLeninist polity. The particular kind of economy to which I refer is, to put it simply, the gift economy (Mauss 1990 [1925]) — though here it is intermingled with commodity exchange (cf. Gregory 1982). In this case, gifts become manifest within a network of relations in which state agents and state subjects are mutually entwined. As a matter of authoritative discourse, such relations are anathema to the project of building communism. All to the contrary, socialist bureaucrats are expected and assumed to act as impersonal subjects who in this instance support, paradoxically, the possibility for all members of the social body to realize their unique personhood. Notwithstanding what Weber has taught us, bureaucracies never work as intended. And Cuban history has shown us that when the bureaucracy fails to inspire modern discipline, the authoritative voice relapses into a kind of tautological apoplexy: "Let us be more socialist!"

I should clarify the claim I have just made. Exchanges of the sort that do not involve the alienation of persons, as abstract labor, and things, as commodities, but rather the ownership of all workers collectively over the means of production is a bedrock principle of communist thought. In the ideal, the realization of this principle would represent something like a "return" to gift economics, if only in the sense that in the giving of one's spirit through the exchange of objects one is affirming the collective spirit of a society in all the artifacts it produces as a whole. Yet communism has always been a progressive ideology with a telos that does not really imagine for itself a return to the primitive. Rather, its most prominent thinkers all embraced the possibility of a technologically advanced future wherein human ingenuity and its material products are owned by and 
accessible to all who share in the productive process. What's more, Marx's materialism never strayed from a hierarchical view of cultural organization, which like Tyler's social evolutionism afforded (for example) small-scale foraging societies the status of primitive survivals.

To sum things up, socialist economic ideology has something of the flavor of gift exchange - in its utopic vision and hopeful discourse — but much of the baggage of Western capitalist principles in its productive ambitions. In urban Cuba, it is as if socialist subjects have taken to heart so ardently the first half of this formula that they have come to regularly deploy it, in very real forms of gift exchange, as an everyday corrective to the many failures of the formula's second part. Maestro realized his roles as administrator, friend and elder by engaging with his compatriots in an elaborate performance of gifting, including everything from the veggies he brought home to his wife, to the production of camaraderie in the central part he played in our Father's Day celebration.

Though he had not known me for more than a couple of weeks, Maestro did not hide from me the fact that all of this was "illegal," as he so bluntly put it. Nor did he or his coworkers in the market hide from the general public the key illegal act to which his statement referred in particular, the beer run. Not all that well, in any case. But they did have a sense of the degree to which they should act as if it should be hidden. Maestro knew the meaning of an open secret and the respect that it ought to be given.

The crucial social fact that calls for interpretation here is that nearly all the activities that self-employed Cubans engage in, relative to their domestic economy, involves brazenly betraying official rules, regulations, and politically authoritative expectations 
while also enacting certain forms of dissimulation to nominally hide the betrayal. As we will see, it is not enough to say simply that these performances were "only" acts, and the obfuscations they rendered "merely" playful, because the players involved more often than not experienced their performances as all too real; on the other hand, these weren't simply calcified hidden transcripts (Scott 1990) to be taken at face value rather than as parodied displays of cultural commentary. What I am suggesting is that they are both. When Maestro covered the basket on the back of his bike, he had legitimate concerns. And he was making fun of himself.

Often the means for articulating such creative ambiguities drew on the authoritative discourse itself (cf. Yurchak 2006). The speech acts (Austin 1962) that are crucial to justifying, explaining and performing seemingly "dangerous" routines, as in the everyday ritual I have described above, used a recognizable code. This code was grounded in those key verbs I have already identified: luchar, resolver, inventar. On our walk back to the agro, Maestro described what he was doing in terms of the "struggle" that all Cubans like him engaged in on a day-to-day basis. This struggle in turn referred to all of the acts of resolving entailed in the festivities, including: however the beer family got a hold of their product; whatever dealings the market staff had to make, collectively, to obtain it; even whichever contacts were called upon in rounding up the Havana Club cups — probably from a tourist hotel — and their more modest counterparts, the drinking vessels cut away from used bottles.

Resolving these things required, like socialism itself, inventive symbolization as a matter of course, supplementing but not necessarily supplanting one's "real” (legitimate, 
official, open) ideas about work. But the struggle, the resolving and the invention, in this instance as in many others, also signified an escape from one's official zone of existence. On this Father's Day, Maestro and his friends engaged in these acts unapologetically in the service of relajo (relaxation), a Cuban colloquialism meaning, more than passive relaxation, an active, festive leisure, even in some cases "chaos." This specialized code helped Maestro justify and make sense of the fact that what we were doing was illegal, all the more so given his status as a putative agent of the state. As neither the social labor he carried out in his errand nor the means of production involved counted for him as aspects of his real "work," he concluded: "It can't be all work. You have to live too."

This re-appropriation of authoritative discourse so common in the invento market frequently played on the radical nationalism the Revolution has fostered. As we have seen, Cuban intellectuals and political leaders historically drew on a nationalist ideology to define and produce the Cuban nation as a people vis-à-vis colonialist, imperialist, and occupying political forces. And the socialist state, as it became institutionalized, capitalized on nationalist sentiment and the idea of Cubanness (cubanidad) in outlining the terms of its own legitimacy. It has made the Revolution synonymous with Cuba, so anything deemed counter-revolutionary is cast as inherently un-Cuban. Those who have left the island in the revolutionary era are not worthy citizens but labeled instead as "worms," while those on the island with moral and financial ties to the departed run the risk of being labeled as "scum." Being Cuban is felt, additionally, in a deeply naturalistic fashion. There are foreigners "from outside" — and then there's "us," inside. While naturalized citizenship is possible in legal principle, it is not really felt as practically 
feasible. The ajiaco of which Fernando Ortiz sang is understood as a thing of the past, a stew that is finished and served. Being Cuban is thought to consist in something acquired from birth as well as lived experience, as if it sprang from the island itself and from the essence of its people, no less autochthonous or irreducible than the caguairan hardwood, which often serves as a metaphor for the nation, the Revolution, and Fidel himself. The ideology is likewise rigid, so much so that even though rejecting the regime and el comandante in the safety of one's intimate circles was not all that problematic, no one I knew ever rejected, denied or obviated their own basic cubanidad, in public or private. Instead, they invoked a nationalistic pride precisely to express frustrations with or simply to make fun of what they called "the system." And yet - even at times in the same breath - my friends would grieve the hopeless fallibility of all things Cuban, including themselves. This was a kind of double nationalism, with positive as well as negative registers that worked in tandem, at once reproducing the state's nationalist ideology while carving out a life apart from, at times parasitic on, what they called the state.

The idea of cubanidad appeared in almost any description of the content or quality of events, major and minor. Many times during that Father's Day celebration the agro vendors along with Maestro professed that what they were doing "could not be more Cuban." Sometimes the references seemed superficial. They came, for example, in pointing out how the food and the music were intrinsically bound to the nation. One young butcher was absolutely unconvinced, given that I had Cuban grandparents, that I could not dance salsa; he tried to walk me through the steps on the spot. But references to the nation were just as easily abstracted from the material facts of the gathering. These 
included pointing out in no uncertain terms that the event was organized at a grassroots level, that it lacked state support or sponsorship, except in the sense that the "area chief" of the market (a woman with a booming voice, to whom Maestro ultimately reported) shielded the ritual from wider official scrutiny. In a similar way, the nationalist discourse peppering our conversations alongside the stewing pork worked as a shield against whatever fines, police intervention or other nuisances might befall these agro workers, already so tenuously categorized as cuentapropistas: If being Cuban cannot be called into question, and this party could not be more Cuban, then it too - and its productive means by way of invento - could not be questioned.

It could however be lamented. Take, for example, Diego, who was another administrator and Maestro's immediate supervisor. He was tall and wore a bushy mustache like Martí's. Sipping beer with me that day, he told me his mother-in-law had recently arrived from Miami to spend time with her family. Diego also said he had aunts in the United States. But they never sent him anything. And the mother-in-law did not bring much with her on this trip. "It's all right," he said, though his tone of voice suggested otherwise. "I have all I need in Cuba. ... Over there, people say they work all year long and get a month of vacation. But here people hang out, have fun, enjoy themselves, all year long, and we work for one month." Diego laughed at his own joke, a kind of nervous laughter. Clearly, he was pleased with the self-effacing insult, proud and at the same time insecure about the implications. Cubans in these predicaments found themselves responding to the gap between the authoritative discourse and the state's increasingly capitalistic practices on their own terms. For many, this led to a 
contradictory moral outlook: at once complaining about and relishing in the absurdity of their survival strategies. For others, it was cause to become, simply, indifferent to political questions: to adopt a kind of politics of indifference. In the chapters to come, I address these responses in turn as the "morality of invention" and the "politics of morality."

\section{Markets and moralities}

In making sense of this context, I've found it helpful to bear in mind the lessons learned from ethnographies of socialism elsewhere in the world, and especially Eastern Europe. As the introduction to this work claimed, this literature taken as a whole suggests a nuanced reframing of the central problematic of entrepreneurship under late socialism. Whereas Peters (2000) frames this problematic as a question of how the "free market" will survive despite the continued influence of state socialism, we should instead ask how relations of reciprocity still prevail for cuentapropistas in the agro and beyond - in spite

of state practices that tend to individuate subjects, turning them toward the service of "the market" and "the economy."

If ethnographies of socialism have helped set up this question, recent work on the postsocialist context has begun to answer it. A brief review of this work will help set the stage for a systematic ethnographic account of invento ideology and practice. In a volume titled Markets and Moralities, Mandel and Humphrey (2002) have collected a set of ethnographically rich studies from the first post-Soviet decade. Not surprisingly, several of these studies can be productively compared to the issues raised in accounts of Cuba in the Special Period, especially this one. Recall that although the communist political 
system did not collapse on the island during this time, and capitalist "shock therapy" has not yet been the order of the day, the government has gradually instituted many of the reforms seen in that time in Russia and the former socialist states of Eastern Europe. The result has produced moral ambiguities similar to those outlined in that volume's introduction (Humphrey and Mandel 2002) — ambiguities, the authors contend, that are rooted in a clash between idealized socialist values and the political-economic framework of the global capitalist market.

In the coda to this work, I will return to this notion of a postsocialist ideological "clash" and engage it in a sympathetic critique. For now, I want to build on it, along with the ethnographic analyses collected in this volume, as providing a useful rubric both for contextualizing the case of Cuban invento and undermining economistic skepticism about the fact that all markets are moral.

The contribution from Kaneff (2002) is especially instructive. Providing a focused account of a mother and her grown daughter, she shows how prior dispositions shaped the respective moral sentiments these women felt in a new entrepreneurial sector. Kaneff's research participants operated a produce stand in Bulgaria in the late 1990s. The daughter, was a dedicated government official in the days of socialism, and now experienced shame working in the market, feeling that it contradicted the socialist ethic as she understood it. The mother, never having identified strongly with the old regime, felt reinvigorated and proud of her new economic activity, although she approached the work through the lens of production in common for the household. While this situation is not one that is directly analogous to Cuban invento, the broader theoretical implications 
that Kaneff draws out certainly are. Far from producing morally disembedded markets in which the profit motive in simple terms reigned supreme, the postsocialist context for her informants demonstrated how the marketplace could be a site where "issues of morality were vocalized and given prominence" (Kaneff 2002: 46; cf. Dilley 1992). And the content of what was vocalized reveals that "local mores" and ideas about the self "remain prominent features of market activity" (2002: 48).

In a historically textured study of mountain villagers in southeast Poland, Pine (2002) observes how moral dispositions toward alternate experiences of money and "the market" have changed over time, and she charts the political implications of this shift. Under state socialism, migratory highlanders valued greatly the earnings they received (often in foreign currency) from their collective entrepreneurial practices, but they generally scorned wage labor and Polish money, associated as it was, in their view, with alienation and inequality. Because socialism promoted wage labor for the state as the path to an egalitarian society, highlanders beheld the state itself with contempt. In the postsocialist era, however, their hostility has been focused on Westernization and corporate business practices in Poland. Consequently, their valorization of money has shifted from foreign to domestic currency, and their politics of hostility toward the state has been replaced with a concern for mitigating the effects of globalization through state interventions.

Similarly, Watts (2002) describes how an ethnic group in northern Russia known as Pomors suffered under state socialism because of their alternative economic value system, which prized self-sufficiency and entrepreneurship rooted in their subsistence as well as market-oriented fishing activities. In the years of Stalin's rule, they were derided 
on one hand as primitive and on the other hand as incorrigibly bourgeois. Although this valuation changed under perestroika, they have not fared much better after the collapse of the Soviet Union and the onslaught of corporatization in Russia. Taken together, these realities go to show that small entrepreneurs do not necessarily experience or expect a universal "market" in which to operate. Rather, their particular markets are inflected with the moral dispositions they value. Those values have staying power, and consequently we might also say they speak to power.

For these reasons, I want to emphasize that we should not take all forms of invento in late socialist Cuba as necessarily equal. I use the term in reference to what my relatively poor cuentapropista informants experienced as their own way of conducting relations in a market context. This use follows, to a degree, the useful taxonomy of native terms for marginally legal activity outlined in Weinreb (2009) — undoubtedly the most significant monograph on daily life in urban Cuba to have emerged in two decades (see Armengol 2011). On the other hand, my analysis in many respects stands in contrast to her approach and arrives, consequently, at rather different conclusions.

Understandably distressed with the disillusionment she witnessed among the habaneros, or residents of Havana, who crossed her path, Weinreb asserts that she will not relativize the notion of "citizen liberty," choosing instead to take at face value the native exegesis of frustrated consumer desire she found amid what she calls a Cuban “shadow public." Partly, this is a problem of deciding who constitutes "the public." Most of her informants, though they are disaffected with the one-party state, appear to be wellconnected with "the outside" and thus have relatively easy access to hard currency. But 
the bigger issue is theoretical. In abdicating a culturally relativistic approach to late socialist Cuba, Weinreb ends up reproducing consumer desire and the market as natural facts of life. In doing so, she fails to interrogate the social dynamics underlying her informants' performance of frustration, or to situate it in the context of a rapidly changing political economy. As I have claimed in this chapter, Cuba's market of invention in fact is historically contingent and morally differentiated from official discourses inside and outside the island. In what follows, I offer an extended account of precisely what makes it culturally distinct from orthodox ideas of the market. 
El cubano lo inventa todo.

\section{THE MORALITY OF INVENTION}

All markets are moral. This is not a truism but a powerful finding of the anthropological tradition that cannot be overemphasized beyond our discipline. I have developed it at length in the previous chapters because it is crucial to understanding the subaltern political project my research participants enacted in Havana at nearly every turn although they themselves, understanding the term "political" in a different light, would have denied the political nature of their struggle. In what follows I unpack the form and content of this struggle, describing how it arises out of everyday acts of invention within a market context, how it is produced by and productive of a particular morality of exchange.

All markets are moral: but this premise is empty if it is not particularized in a definite set of market practices, with a discernible moral grammar. It is one thing to show that even capitalist exchange happens in a cultural register. The more crucial fact for an anthropological politics of opposition is that such registers are variable across time and space, and not everywhere dominated by modernist assumptions about human nature. The political project my informants enacted arose out of what they themselves constantly called invento, a form of economic inventiveness realized in dense networks of reciprocity, producing a morality of solidarity. I call this morality of invention "competitive solidarity," because Cubans involved directly and indirectly in self- 
employment engage in competitive market practices marked by the ethos of gift exchange. And yet, these are hardly social actors who have cut themselves loose from the moorings of state socialism. On the contrary, "the system," as they called it, provided for them much of the moral reasoning for their everyday practices. This was true even if the authoritative discourse of the socialist state had to be turned on its head, or against itself. What's more, my ethnographic data suggest that in the process, the system was not infrequently made subservient to their inventiveness. This is in the end what I find most compelling about the "invento market." It is a moral economy capable of reshaping state power at the level of everyday life.

Self-employed Cubans (cuentapropistas) are no more inherently creative or clever than anyone else, of course. What is odd is that they are exceedingly aware of their inventiveness. It is a social mode that is popularly theorized and metadiscursively elaborated. Invento is a native category, and arguably a master trope in contemporary Cuban society. One of my friends, something of a roving huckster who sold pirated videos on the street, liked to repeat a common saying, in a tone at once admiring and cynical: "The Cuban people invent, the Cuban people invent everything." He might say this referring with glee to the brand-name razors he once procured from a friend with connections in Miami: He then sold them in hard currency to trustworthy clients. Or he might say it with despair, in reference to an invention of the state's making, for example: the dilapidated tenements in his neighborhood repurposed from abandoned whore houses.

Both these invocations of invento reflect the morality of invention. In this chapter, I develop this moral paradigm through an ethnographic analysis of the invento market. It is 
in the daily practice of Cuban inventiveness that the core features of competitive solidarity are brought to life. I address these interrelated features in turn, tracing their production through exemplary events, key moments, life stories and recollections, and direct observations of exchange. Together, they foreground a moral landscape in which the invento market is embedded, entailing through it a subaltern political struggle.

\section{Inventing a Moral Landscape}

An all but sacred assumption of neoclassical economics is that human beings are selfish and maximizing. I have already rehearsed the logical and empirical flaws in this assumption — in particular, its denial of the a priori fact of cultural transmission through social relations - a critique that anthropologists among social scientists are formidably positioned to make. Assuming this critique, however, mainstream sociocultural anthropologists tend to take values other than those concerning material wealth and production as their primary object. This skirting of economic issues has been especially pronounced in the literature on Cuba for reasons explored in my introduction.

Following Graeber (2001), I examine the morality of invention as a system of values that emerge in action, wherein cultural values — and "economic" ones — reflect the relative importance that people give to each other's creative activity. This kind of thinking, Graeber suggests, paves the way for a new sort of "materialism" in anthropology, one that equally rejects the determinism of cultural ecology and the nihilism of postmodern scholarship. Such a perspective takes as material in fact all aspects of culture, privileging neither abstract ideas — which can only be transmitted in a 
concrete media (speech, songs, books, newspapers, pyramids, rituals objects) — nor "basic needs," which are always realized through a more or less crystallized set of ideas, recipes and structures (working in an office, shopping at a grocery store, hunting elk, or sneaking tobacco out of a state factory, for example).

In hewing to an analytical paradigm of detached semiotics, anthropology risks continually ceding to economists the legitimacy to say anything about modern economic systems, which are always embedded in a set of social categories and prescriptions. This resignation, I have suggested, occurs by sleight of hand. The critique of economism is thought to have triumphed, allowing us to focus on other things. My contention throughout this dissertation has been that such a critique, to be sustained in a prolonged way, must focus precisely on things "economic."

Because material things matter. In many ways, late socialist subjects are even more obsessed with what the dismal science calls "competition for scarce resources." The material crises of the post-Soviet era in Cuba - with its shortages of staple foods, its power outages, its salaries that do not make ends meet — have a way with making the material facts of life indeed all the more salient. What is noteworthy is not that people spend a great deal of time concerned with such things, but how they are concerned, i.e., the moral landscape of their economic worries, and what forms of action that landscape makes possible.

Invento: Make relations, with things

In the invento market, material demands were understood as part and parcel of relational demands: things served to make social relations, and these relations produced 
things for people in times of need. Consider César, a vendor at the plaza. Relaxing after work one night, over a drink with friends on a curb in front of a Cuatro Caminos divisa store, he told me, "We Cubans are always thinking." By this he meant: thinking about how to make a few more chavitos. He said he went to sleep most nights with this quandary on his mind, considering new ways to "invent," hoping that one of them might prove fruitful. Sometimes César would awake before sunrise with thoughts of all the things he was expected to spend money on in the course of the upcoming day: "I'll think to myself, 'OK, I have to buy pork, I have to take my woman to the hairdresser, I have to buy new spokes for my bicycle... .',

He said this having just spent a large portion of what he made that day treating several co-workers and me each to a beer, refusing reimbursement or anything in return. This might seem like an irrational waste of money for someone of little resources, but in the moral universe of invention nothing could be further from the truth, since occasions such as these might be seen as investments in social relations over and above overtly material ones, but which themselves are of material significance.

Members of the entrepreneurial and working classes in Havana all had stories of getting by, of their own inventiveness, some more desperate than others. But, by and large, these were not stories of individual success, quite unlike the fable of the American Dream. They were stories of how meeting something close to the culturally accepted standards of food, clothing, shelter and leisure was made possible while at the same time not central — not paramount with respect to one's social obligations but fully subservient to them. What kept you up at night (as César explained) included, in part, the fact that 
you were obliged to negotiate your needs and desires with the needs and desires of others, to varying degrees, depending on the proximity or distance of these others involved in your social world, in accordance with the unwritten morality of invention. The inventiveness in invento involved just this sort of social calculus. It was not always possible for César to treat his friends to a beer, but on other days they would reciprocate in unanticipated and unpredictable ways, perhaps after work in another ritual libation, or during the day, in the plaza, in the form of certain favors, say, manning César's tarima for him while he went out on a personal errand.

In other words, to be understood as invento, one's inventiveness cannot amount to an individualist project. It could not be work solely for one's sake, or even solely for one's immediate kin, but is linked inherently to one's larger network of social relations. Invento as such helps solve the everyday material problems of its subjects but is valorized, and made legitimate, through the mutual recognition of the ways in which one's inventiveness is put at the service of others. Value, as Graeber (2001: 70-77) shows, arises from the twofold action of human creativity coupled, through exchange, with the gaze of society. Here the dialectic of invention and moral judgment serves to produce solidarity as an end in itself — which becomes the object of accumulation. While not always followed, this proposition was implicit in the relations themselves, and conveyed time and again in personal parables about the importance of realizing one's obligations in a field of exchange. I mean realization in two senses of the term: realizing as recognition (of standing relations) and as creation (of new ones), which could occur even in entirely spontaneous ways. 
This is illustrated well in the recollections of one woman whom I came to know because she often helped me obtain tickets to ballet performances and other popular events, such as the Havana Jazz Festival, at very inexpensive domestic peso rates - one of her specialties. Loreta was a central figure in a close-knit community of ticket scalpers and a ubiquitous presence in a popular area near the old city. But long before she became involved in this business, she worked in a more official capacity styling hair for foreign clients at an international resort in the coastal town of Varadero, two hours east of Havana. This was a job she landed through a chance meeting on the beach while trying to sell some Montecristo cigars that she said she had "resolved" through a friend.

Loreta had only been planning to stay in Varadero a few days. But she ended up living near the beach for three years. She landed a room in what she described as a gorgeous, spacious colonial-era row house where an elderly woman who had been living alone charged her one dollar a night. The location had been recommended by a friend. Out of kindness to the woman, Loreta recalled, she advanced her a week's rent plus three extra dollars and took her shopping for food. They bought fruit, vegetables, some meat and cooking oil. "The house was full of this beautiful antique furniture, worth who knows how much," Loreta said. "But the woman was practically starving. She was from another time ... when those material things really mattered to people. She could have sold them but she didn't want to let go."

In those years, Loreta did a mix of work for the state, at the resort's hair salon, and informally for Matilda, the elderly woman. But Matilda did not pay her for this de facto hospice care. Rather, it was Loreta who continued to pay rent. This was itself a form of 
invento, she pointed out; negotiating rental agreements with fellow Cubans who were not licensed as landlords was generally prohibited. In Loreta's view, she could not in good conscience hold a lucrative job at the resort, receiving tips in hard currency, while not also helping Matilda. This was all the more true given that her host seemed to be "from another time," which is to say another culture. Loreta was by no means a party propagandist. Nor, however, was she especially nostalgic about the capitalist past. In taking responsibility for Matilda's physical care, she was also adopting an ideological obligation to incorporate Matilda into a morality of invention that stood in contrast with the "old" system of value as well as the "new" one.

None of this is to say that Cuban people denied the instrumental aspects of the relations they built through inventiveness. When I pressed Loreta about how she benefitted from her stay with Matilda, beyond the affordable rent, she was decidedly oblique, especially for someone who otherwise loved to talk and had an imaginative way with words. She didn't deny that there were return gifts of some kind, but she didn't feel comfortable discussing them in detail.

This was so common a reaction from my interlocutors that I can safely call it a general principle of invento. After spending a whole day with a self-employed carpenter in a state-owned workshop — he used connections to gain after-hours access to this expansive and well equipped facility — I asked how much he typically paid the handful of men who worked for him, building elegant cigar boxes. Dante was candid about many other seemingly more controversial issues, like the fact that his business was totally illegal. And yet he would not say much about wages or the agreement he had with his 
employees, acknowledging only that "yes, of course they get paid, but it's not a fixed, definite thing." As with most invented businesses, the staff were family and close confidants, and they did not receive wages in the usual sense. There was compensation to be sure, but these exchanges worked in both directions and produced claims against one's labor and one's belongings on both sides of the equation, for workers and boss. All the people I knew who were involved in businesses like this one, regardless of whether the enterprise was licensed, avoided concretizing their relationships for themselves, let alone for an outsider.

Consider once more Carlito, the cranky produce runner whom we met in Chapter 1. Even he insisted that his boss was like an older brother. This was more than mere talk. It reflected a "tarima kinship" that I found at work throughout the plaza and, in my estimation, other agros and well-known zones of cuentapropismo.

Seemingly at random and without fuss, Carlito made appropriations from the tarima's cash pouch for his own lunch, coffee, cigarettes, and other items. In exercising these and other liberties, often coming and going as he pleased, setting his own hours, etc., Carlito retained a measure of independence and equal footing with Yoni, his boss and the tarima owner. While technically working as a wage laborer, Carlito's status in practice was more like that of a business partner. Yoni, in turn, expected Carlito to share whatever small luxuries he bought with tarima funds, if asked to do so, and to keep the business running smoothly whenever the boss couldn't be around. Neither felt any need to keep close track of such things because, after all, they thought of themselves as family. Carlito also used Yoni's tarima openly for freelance work, selling chicken under the counter for yet 


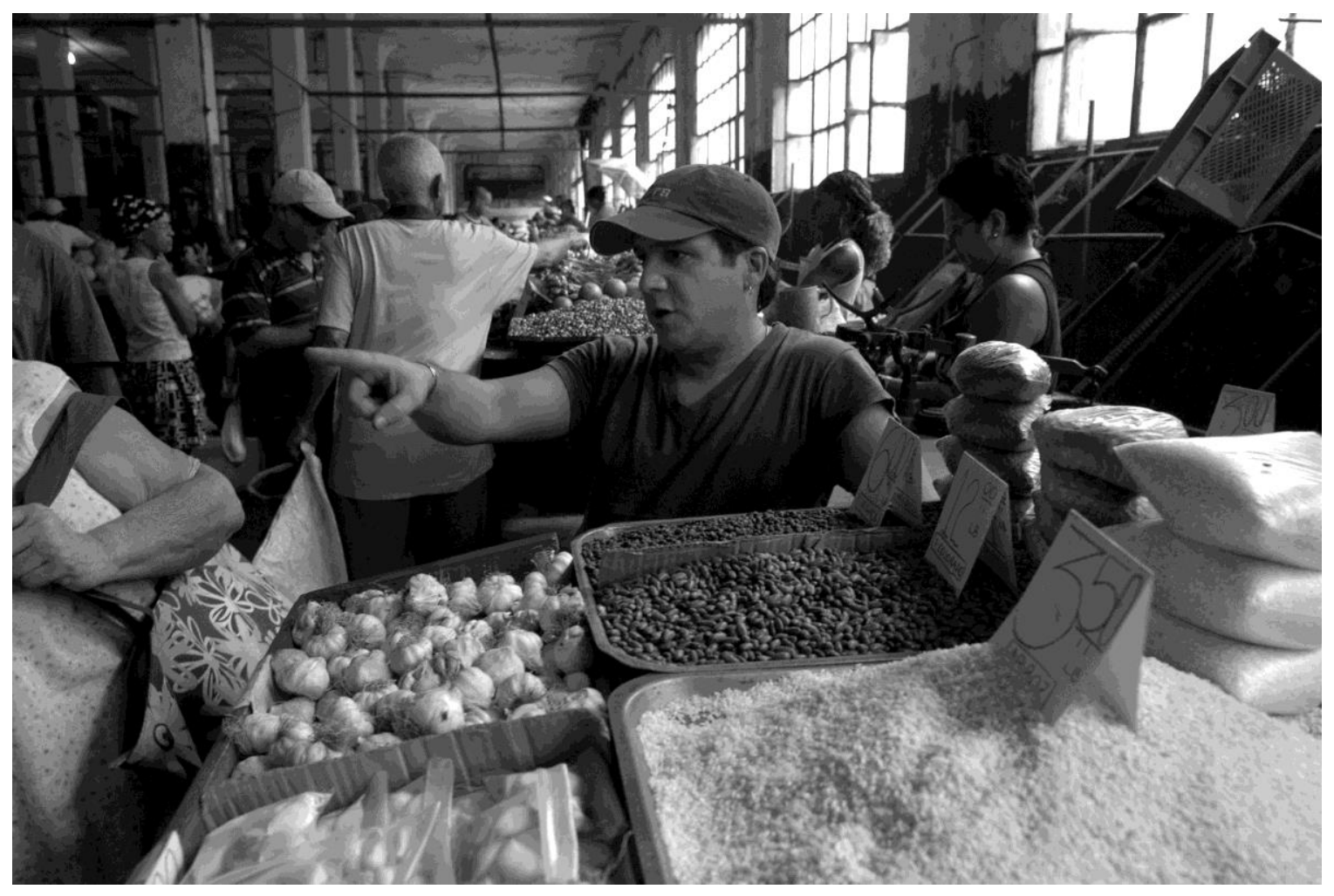

\section{PHOTOGRAPH 3.1}

Tarima kinship. Investors and workers operate closely, often in a de facto partnership.

another friend. Although he denied the fact that these sales brought him personal gain, he also talked vaguely about the "help" he received from the man who procured the chicken. Just as the chicken sales were (ostensibly) concealed from view, so too were Carlito's material motivations (ostensibly) obscured. It became clear that return values were to be expected sometime in the future as part of the endeavor, but these could not be named explicitly.

In the introduction to this work I suggested that Carlito enacted relations of economic solidarity that complicated his purported "conservative Republican" values. Put a different way, there is an apparent contradiction between the morality he espouses and 
the morality he inhabits. Among the Cubans I knew, this was one way among possible others to obviate the central paradox of reciprocity: that in uttering the name of the gift one threatens in that instant to undo its power — the power to bind giver and receiver.

Others had less polemical strategies for making money "matter, but not too much." For example, handymen working illicitly, or "on the left" in Cuban slang, rarely dictated a price for a particular job, inviting clients to pay "what they felt was fair" or "whatever you can." This exchange, arriving at the end of each job, had a common structure: first, a studied verbal back-and-forth on working with people you know you can trust; next, a performative reluctance to accept payment; and finally, having accepted a wad of cash, this request or something like it: "Let me know if you or your kin ever need anything else. And if you know anyone who needs plumbing work, look me up." Referring to this kind of work with the clever euphemism on the left (por la izquierda), it must be said, is purposely ironic, since communism imagines itself as is a leftist utopia, but the left is also symbolic of that which is sinister, dangerous, problematic.

\section{Reciprocity: Turn the market inside-out}

Was this dance, with its happy outcome for the handyman, a market transaction or an exchange of gifts? The answer is both. I have already suggested that preserving the analytic distinction between gifts and commodities is indeed useful for a comparative research on political economies (Gregory 1997). Yet this analytic distinction should not be conflated with the distinction of "market" as a mode of exchange versus different modes of exchange, such as the potlatch or the kula or feudal redistribution. While the formula "market equals commodity sphere" seems perfectly reasonable on first glance, it 
relies on an underlying category error. While capitalist markets are arranged so as to lend themselves well to the circulation of commodities (i.e., alienable goods), the "market" in the sense that I have been defending (as a site, be it physical or conceptual, where values are exchanged for professed equivalents) does not in and of itself preclude the exchange of inalienable artifacts or the mixing of gifts and commodities. Making this mistake allows us all too easily to see any monetary transaction as "of the market" and therefore "of commodities," and therefore "capitalist," in both a formal and practical sense. But what happens when gifts move through markets, when a market becomes adapted for generalized reciprocity? The nature of the market, of course, is fundamentally altered. This is precisely my claim about the invento market in Cuba and subaltern economies more generally.

Invento occurs in a thoroughly market context. Indeed, it is rooted in market mechanisms and has effloresced with the continued opening of markets and entrepreneurism in Cuba, to the point where it is fully, and incorrectly, read as a form of homegrown capitalism, even (as we have seen) by authorized Cuban scholars and the state press. But the ethos of invention is reciprocal - not merely the ethos, as a matter of fact, but the actual praxis.

Let us return to the handyman. In my example above he was imagined in composite form: I met many Cubans like him. Paco was among the more memorable and perhaps the best at describing his own line of work. A jack-of-all trades, he could with some inventiveness of his own fix just about any home or office appliance, repair any car or bike, find you gasoline or potatoes when no one else could, and knew whom to contact 
when he himself couldn't do the job. Although he did contract work for a state firm serving expats, Paco had no steady “job,” even by cuentapropistas standards. But he did have a certain regular, reliable client: Lourdes, a middle-aged woman who was licensed to rent a room in her home to foreign tourists. Actually, like more than a few registered landladies, Lourdes often rented the entire apartment, located in one of Havana's middleclass neighborhoods, to long-term tenants, often international students, diplomats, or the managers of foreign companies permitted to work in Cuba. She charged them the going rate in convertible pesos, about US\$700 per month - a huge sum relative to the typical state salary, much of it gobbled up from her in taxes and fees.

This practice flouted the usual rental rules, and there will be more to say about Lourdes's relationship with the agents of the state. For now the relevant point is that homeowners in this line of work frequently required services for which, as a practical matter, no state enterprise existed. Also, given the marginal status of such inventions, availing oneself of state services could present legal challenges. Finding themselves in the paradoxical world of sanctioned but officially ostracized work, but also controlling a fair amount of hard currency, registered landlords in Havana all seemed to have a person like Paco on their side, if not several of them.

Paco and Lourdes met thanks to a mutual acquaintance some years earlier. As Paco recalled, Lourdes needed the iron bars on a window welded back together. He wanted to establish some rapport with her and didn't charge as much as she expected. Paco liked to say, "I'm not into exploiting people or any of that." Lourdes respected greatly his candor 
as well as the initial discount he gave her. Paco also had a good sense of humor and quite a personable disposition, which Lourdes appreciated. They hit it off.

As their patron-client relationship developed, the forms by which Paco received payment became increasingly convoluted and less susceptible to standard capitalist accounting, as if by design. Though their exchanges still involved money, and Paco might still "bill" for a job by explaining to Lourdes in some detail what a new showerhead cost, and how much time he spent to replace it, their transactions hardly resembled anymore the exchange of alienable goods. Renewing their social bond and the trust they had in one another became as much an object of each transaction, large and small, as the work itself; sometimes no money traded hands at all. But Paco counted on Lourdes to lend him funds when he lacked the resources to visit his wife and children, who lived in another city. Like Paco's services, the terms of these "loans" were difficult to disentangle from the overall web of reciprocal relations they had by now built up for themselves. Lourdes told me once about how she was happy to lend Paco sixty convertible pesos to help him get his brother out of some kind of trouble with the law. Lourdes's husband, who worked as a state-appointed defense attorney, offered Paco legal advice. Another time, she provided her friend forty CUC for another personal problem, and on this occasion told him absolutely not, under any circumstances, to worry about paying her back.

"Paco owes me a lot," Lourdes once told me. "But he's a very dependable guy, very faithful. When I have some kind of problem with the house, he comes over right away and does the work right here and never charges me." 
Lourdes had similar relationships with others who helped keep her business afloat. She viewed her good fortune - the house had been left to her by an aunt with no children or other immediate family — as an obligation to spread the wealth that she could extract from it. She lived well, by Cuban standards. She had a small car and a large second home (belonging to her husband's family), where she stayed most of the time. And having frequent contact with foreigners also made it possible for her to have consumer goods that weren't easy to come by in Cuba at the time, such as a microwave, DVD player and an old but working computer. She held a secretarial job that kept her busy beyond her rental business and gave her a measure of security and a formal status other than cuentapropista. "Any day," she would say, "this rental thing might disappear. You never know." Lourdes was decidedly middle-class in her outlook and education, the sort of person who might have larger ambitions of wealth, but she understood and accepted the unspoken moral obligation that her access to the hard-currency world meant. This job, for one, was the primary support for her husband's extended family, which included several uncles who had little or no income of their own. Beyond that, almost all the closest neighbors to the rental apartment were involved in its working and benefited financially from it. An elderly woman upstairs did laundry for the tenants and frequently offered to cook them meals. An elderly man down the street ran errands related to the household. Others kept an eye out for inspectors or possible thieves. Lourdes made sure to keep all these people in her good graces, and to remain in theirs. She even supported a woman who was infirm and could do little in return, except (if necessary) to defend Lourdes against possible problems with the authorities. 
This was a pattern I witnessed among all the most successful cuentapropistas I met in Havana. Indeed, the degree to which others were involved in the business was a primary measure of success, and those who didn't share the wealth in such diverse ways did not last long in the invento market. This was true in part because they might be more likely to run into bureaucratic troubles; not infrequently entrepreneurs would say they had to be careful not to incite jealousy in others, lest someone point the agents of the state in their direction. But by and large, cuentapropistas of all kinds considered the threat of a government crackdown less noteworthy than a personal breakdown in the affinal connections on which they relied. Jealousy was one of many possible motivators for such breakdowns, and actual instances of informing on one's friends in ambiguously legal matters of official self-employment were rare - such cases were imagined more than they were enacted. It was much more common simply for close friends who felt wronged to undo their friendship.

Abel, a bicycle shop owner, was as concerned about maintaining these relations as he was about succeeding and growing his business. More than most, he described the pragmatics of this structure in moralistic terms. He was a pious Christian and a member of a group of lay evangelical entrepreneurs who met regularly after work in a private support group. Soft-spoken relative to most habaneros, Abel took pride in the "humility and respect," as he put it, that he showed his customers and business partners. At the same time, he was honest about his material interests and economic ambitions. He had a wife and six children, including several stepchildren, plus in-laws and extended family members to support. During the time of my fieldwork, Abel's business expanded from a 


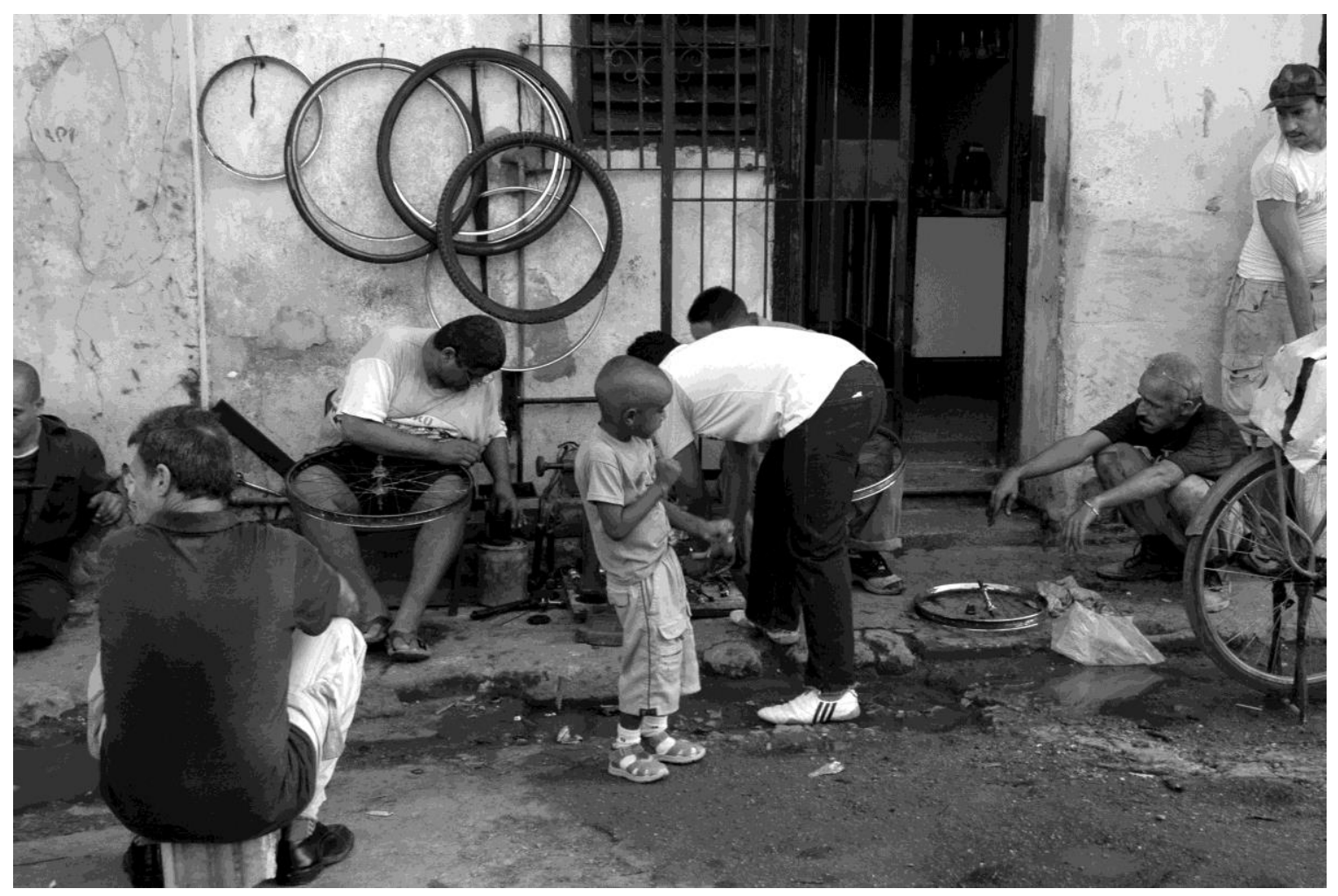

\section{PHOTOGRAPH 3.2}

A bike shop near Cuatro Caminos, exterior view. Bicycle mechanics is a decidedly social affair.

small shop out of a corner home in Cuatro Caminos, near the plaza, to include two more locations within a mile radius. He employed, informally, first one and eventually six other men whom I knew. We talked extensively about his life history, especially his disillusionment with state work: he had been a crewmember on a cruise ship in a Cuban international joint-venture, but was fired after being wrongly accused of harassing a passenger. In Abel's telling, he exchanged the life of traveling, tourism and divisas for the more prosaic, difficult, yet satisfying world of negocios (business), and he openly expressed it this way. More than once, he tried to pique my own interest in investing in his work by helping to secure electronic goods during one of my overseas trips. I declined 
mainly to maintain some ethnographic distance, but I'm sure I could have trusted him to make good on his proposals.

It is tempting to view Abel's livelihood, simply, as characteristic of the path to embourgeoisement in terms similar to what Szelényi (1988) has outlined for rural Hungary in the late socialist period. While not entirely without merit, such a characterization would fail to account for the thick tangles of reciprocity to which Abel had bound himself in the process.

To begin with, Abel did not get into the bike business simply on a whim or of his own interest and merit. He learned the trade through the fellowship of Christian businessmen with which he had been involved for several years, following the lead of an entrepreneur who was said to be the originator of the neighborhood's many bicycle and auto timbiriches, or makeshifts shops set up on street corners or someone's front porch. This man, Ibrahim, and his protégés continued to work in the area and, of course, to compete for customers with Abel. They worked separately, but in tandem, sending each other clients, trading parts and services when needed, and frequently socializing and worshiping together on the weekends. Ibrahim had seeded this industry, and it was successful enough that in a city as large as Havana the existence of such services in this particular area was widely known. There were certain other zones where similar phenomena had occurred in other specialties: plumbing, home construction, and event photography, for example. These zones were by no stretch business conglomerates. They operated in similar fashion, relying on the production of economic solidarity through reciprocity. 


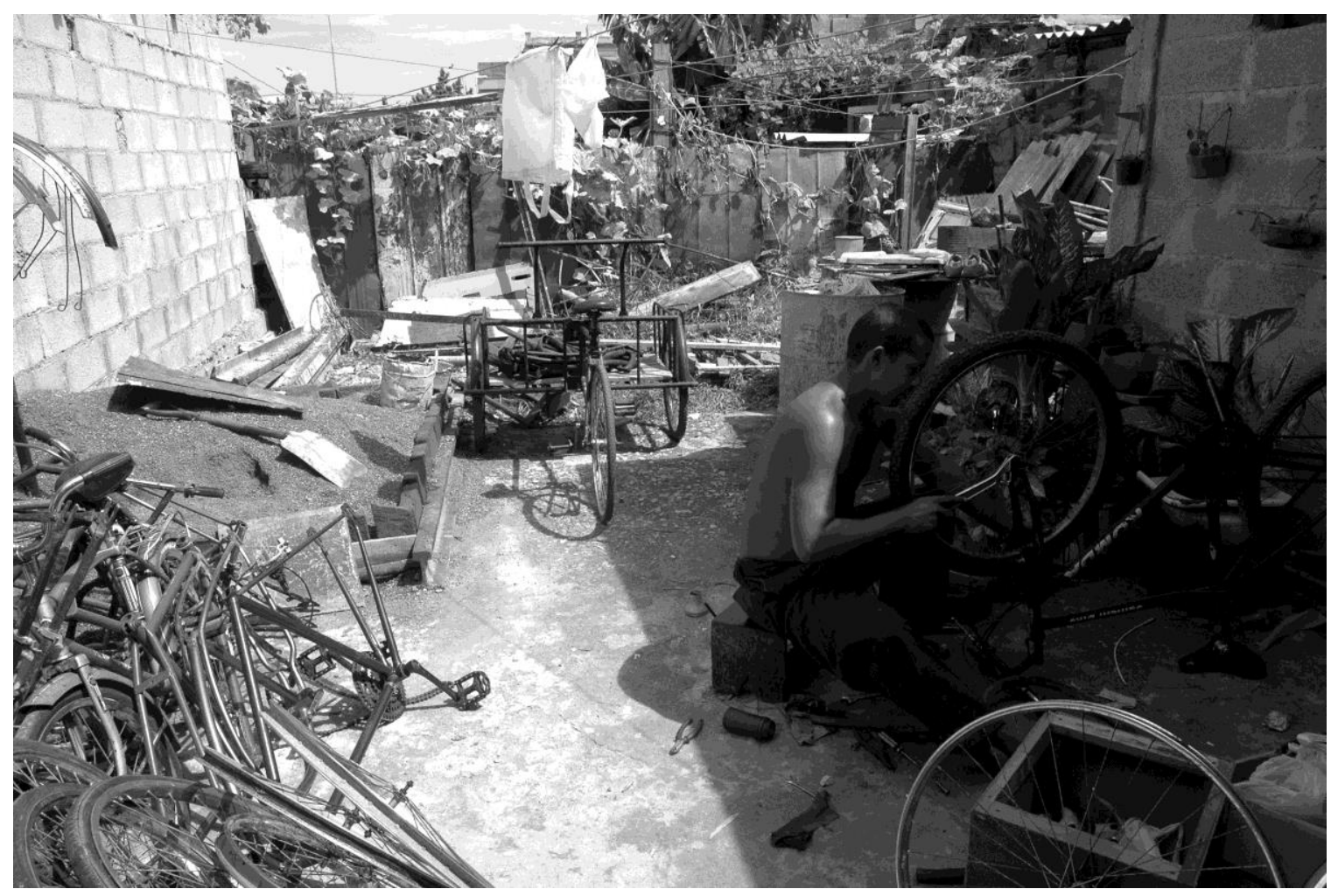

\section{PHOTOGRAPH 3.3}

Bike shop, interior view. The patio of a home has been converted for use as the shop floor.

As I've already said, in Abel's case, this aspect of the moral landscape was inextricable from his Christian worldview. While this was hardly the case for most timbiriche owners, it made his expression of the morality of invention more explicit. He saw the business as secondary to its social effects and thus a key to his "real calling" spreading the good news, person by person. Abel described a religious trip to Matanzas, east of Havana, in which he met some bike dealers who were not especially interested in the gospel or his liberation theology but with whom he could connect on matters of shared obligation to each other's productive endeavors. He told them about what he did for a living and said he could help them by bringing supplies for their businesses, things 
that were lacking in the area but easier to come by in Havana. "This is how you enter the hearts of the people here, through their inventions and their work," he told me. "It helps for them to see that I'm in the same world as they are, and that the message I bring isn't exclusively spiritual, and that it's a message they can recognize. I tell them the spiritual is already wrapped up in the worldly."

True to this sentiment, Abel didn't limit his market dealings to those who shared his religious philosophy. Of his three shops, only one of them was located in the home of another member of the businessmen's fellowship. In all three cases, he paid rent on the left but also relied on diffuse reciprocal relations. For example, the second shop was in the makeshift home of an accomplished bicycle mechanic. Abel's talents (as he readily admitted) were limited, so he counted on the mechanic, Ignacio, to do repairs of any complexity. Ignacio, in turn, was in the process of converting this dilapidated space, in one of Havana's many collapsed buildings, for use as an apartment for himself, his wife, and their young daughter.

When I first met them, the apartment was little more than a brick shell with four walls and a concrete floor covered by a corrugated roof, with a small open-air patio to one side, filled with cinderblocks and other detritus scattered here and there. It was from this patio that Abel, with Ignacio's help and permission, established the bicycle timbiriche. The shop began as a haphazard assortment of frames, handlebars, pedals, brakes, bundles of spokes, spare tires, near-complete bikes of various sizes, and any other related equipment they happened to come by. Gradually, and owing much to Ignacio's technical prowess, they organized all of this in a meaningful way. Meantime, Abel provided, through his 
connections and from his own capital materials for construction projects, including a new floor, translucent roofing to tame the sun's unforgiving rays, and a large metal bay door separating the shop floor from the sidewalk and the street beyond. It was from this opening that Abel, Ignacio and their fellow workers (Abel's eldest stepson and his fatherin-law) interacted with customers, as if it were a drive-through window. The whole scene underscored the inventiveness of this market enterprise.

At the same time, however, this was undeniably a home - Ignacio's home. His wife brought coffee and snacks from within the brick shell a few feet away, his daughter played with her puppy amid the bike parts, and Ignacio maintained a few potted plants and herbs in the back. All the repairs that Abel was financing were at the same time home improvements. Given their multifaceted relationship, I was surprised a few months later when I paid a regular visit to Abel at another, newer shop, this time for an extended interview, and I learned that he had turned over his other two timbiriches, respectively, to Ignacio and to his first business partner, Danny, who controlled the shop-space a few blocks away and also used it as a private barber shop. There had been no falling out, no quarrel or disagreement over ownership. As Abel said, and Ignacio and Danny later affirmed, "the time had come" for them to part ways. In Ignacio's case, his home was complete. The bike shop had become well established in the neighborhood and now had steady clients. Although Ignacio didn't have an official business license of his own, he felt he could manage with the authorities in the usual inventive ways. Abel in turn felt he had done what he could to help his friend. They would remain in contact, and in solidarity, now as fellow cuentapropistas. Ignacio didn't "buy" the business, he simply 
“earned it." What had appeared at first as Abel's efforts to expand his firm in good capitalist fashion had actually been part of an elaborate gift exchange, produced in and through the invento market.

Abel saw these acts in a moral light, but did not conceive of himself as a particularly "good person," in a transcendent sense. What was "good" were the structures that enabled him in this way, not any essential quality in himself. He had made mistakes, he had made poor business choices in the past, he told me. Once he lost a lot of money that a cuentapropista friend had invested in one of his projects. Eventually, he had no choice but to own up to the loss and default. It was a difficult conversation. Abel had suffered a personal calamity and was near tears, he recalled. "I lost your money," he told his friend. "But within the year, I'm going to pay it back, and everything else I owe you — you have my guarantee."

"Listen, kid," the investor replied, as Abel remembered it. "You're my brother, I couldn't do that to you. Don't worry about it."

"No — yes," Abel insisted. "I'm going to pay it all back. Wait and see."

Abel never told me whether he paid it all back. The subject changed and we moved on to other matters. This was, in retrospect, a moral performance. It mattered little, both in the event retold and in the retelling, whether the promises "not to worry" on the one hand and "to pay it all back" on the other were actually followed through; only one of these two potentialities, in the end, could be realized, since they were mutually exclusive. What mattered — the truth of it all — was in the double gesture itself and the solidarity it at once invoked and materialized. 


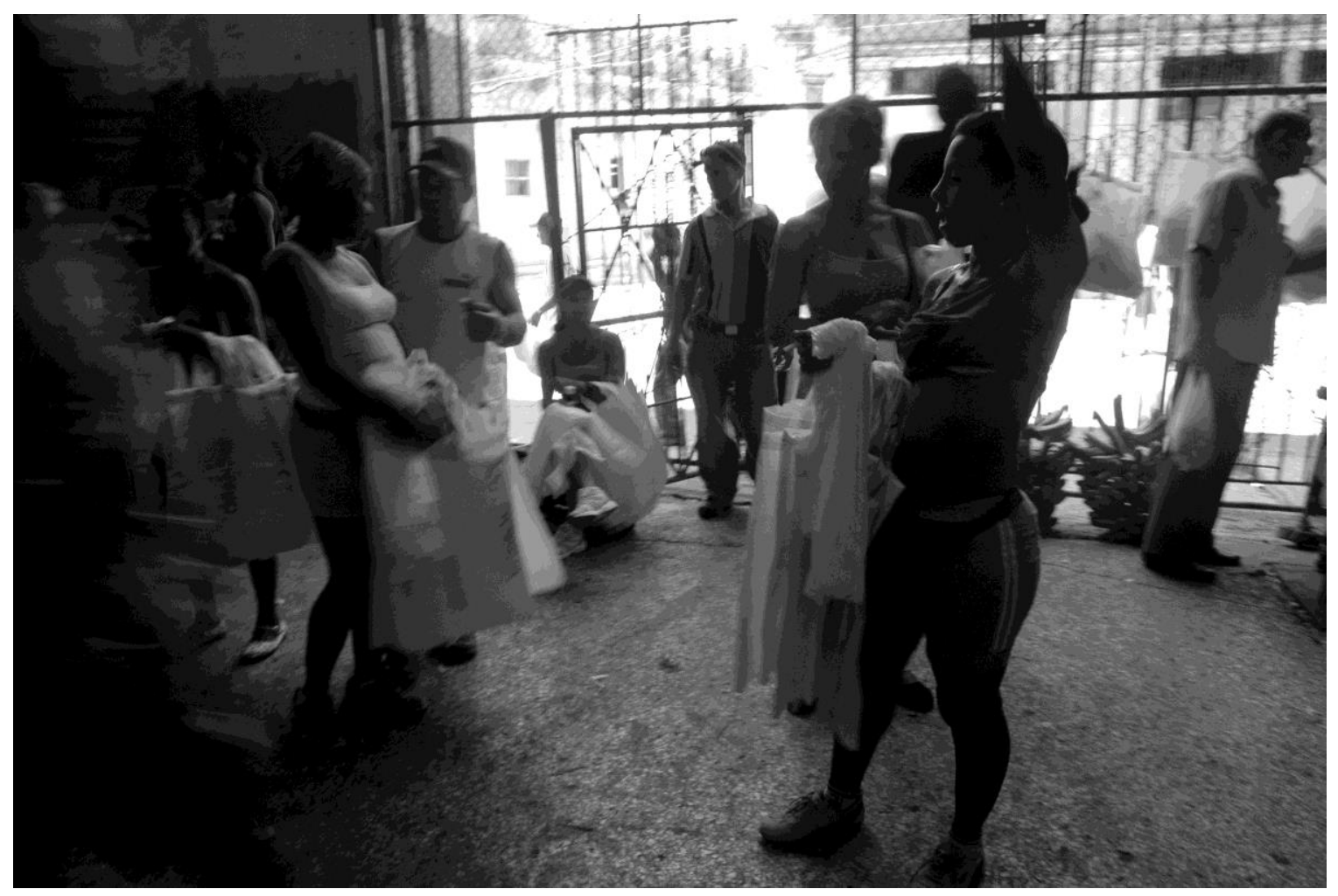

\section{PHOTOGRAPH 3.4}

The jaba women. At Cuatro Caminos, these women compete - and support each other - selling plastic grocery bags obtained through connections, probably from state-run stores.

\section{Solidarity: Compete but do not defeat}

I have thus far tried to disentangle, as constituent features of the morality of invention, three interrelated concepts and the practices which they entail: invento itself; reciprocity, i.e., "the ethos of gift exchange"; and now, more directly, the notion of solidarity. It goes without saying that because they are interrelated, any such analytical move is inherently reductionist. This sort of reduction, however, is necessary and impossible to avoid if we are to interpret the mechanism by which Cuban inventiveness under late socialism consistently produces what I have called competitive solidarity - a 
sort of netherzone between state socialism and global capitalism. Already the ethnographic record presented has hinted at this kind of mechanism. In this section, I explicate this concept more fully.

When entering the west side of the plaza on a busy day, the first thing one heard were the cries of a group I thought of as the jaba women - some four or five associates who sold plastic bags, exactly the kind found at a supermarket checkout line. “;Jabas de nylon!" they yelled in an alternating chorus — "Nylon bags! Two for one peso!" This price held steady during my stay in the field, and equaled eight to ten cents in U.S. dollars. One of the women also, inexplicably, announced that she had soy sauce for sale, inserting a call of ";Salsa china!" between offering jabas. Everyone knew that jabas (and probably the soy sauce, too) were stolen from some state enterprise or another - a divisa grocery or department store or a state-run restaurant, most likely — with help from one's connections in government employment. But no one cared much about this fact, and the jaba women were friendly with the local police. Occasionally, they were harassed or had to lay low during an inspection sweep, but a key part of their work was keeping an eye out for these episodes, warning each other of any trouble ahead, or defending one of their members against any junior cops who acted obnoxiously. Their work and their incomes were nominally independent, and they had different methods for obtaining their goods, but they occupied the same space and watched each other's back. So they were in practice interdependent, and they knew it. This did not preclude gossiping about each other or giving each other a hard time, however. Often this happened if some of the 
women felt one of their members was trying "too much" to beat out the others for customers.

Relationships like this were the norm at Cuatro Caminos, and they were not by any means simple friendships. After some time getting to know workers at the plaza, I was frequently invited to help at the table of one or another vendor, sometimes even to fill in for someone who hadn't shown up for work that day. In these moments, behind the counter, I had my most intimate conversations with vendors. And many times, I was struck by what they said behind each other's back, which seemed to contradict the sense of solidarity they otherwise cultivated in this market-oriented space.

I knew two peanut vendors, for example, who worked side by side and were by all accounts the best of friends, Elena and Adela. Each of them had over time developed fixed customers with whom they had ongoing relationships. These clients bought large quantities and received the best of the product. (For the most part, they were themselves cuentapropistas: maniceros, or "peanuteers," who roamed the streets selling salty roasted nuts in long, thin paper cones, a favorite snack for Cuban children.) Because their preferred customers arrived at unpredictable moments, and the quality of the raw peanut inventory tended to fluctuate, Elena and Adela shared stock with each other informally, as needed, rather than compete for each other's regulars. Their gift exchanges also extended beyond the produce they sold. When either came into some desirable goods trendy new clothes acquired on the left, for example — they gave each other first pick at little or no cost before trying to sell them on the invento market. 
One day I was working for Elena because she had taken a day off to visit family in central Cuba. I found Adela in an especially excited mood. She reminisced in rapid fire about the time she had won 62,000 pesos in the bolita, decided to ditch her prodigal, womanizing husband, and paid off (on the left, of course) the house she was leasing. She showed me a talisman she kept in her purse bearing the inscription, "A. Caminos," which she rubbed for good fortune when the spirit moved her. A term of art in Santería divination, the inscription referred to "open roads ahead," she said, and this was exactly how she was feeling on this day. I asked her at last why the ebullience. She leaned in and whispered to me, in mock secrecy: "Elena isn't here today. I'm going to make a killing!" Adela was quick to add, however, that whatever extra money she made today was important not only for herself, but because much of her income helped support another friend, the mother of her godchild, whose only job was a poorly paying post as a security guard for a state storage facility. This friendship entailed its own reciprocal complex, I learned, since security guards had occasional opportunities to obtain scarce consumer goods, and this helped explain in turn how Adela did not infrequently show up at the plaza with such items. These were in fact precisely the things she often shared with Elena or, instead, sold on the side.

Such relations demonstrate that in subsuming the ideal of the market to an ethos of gift exchange, competitiveness is not obliterated but embedded in a complex of reciprocal relations. The guiding, unspoken moral logic might be summarized as "compete but do not defeat." This logic extended beyond relations among economic peers, spanning domains and types of relations, including labor relations. In the eyes of the socialist state, 
one of the more questionable ills of the self-employment world was the growth of wage labor, entailing relations of employer to employee — assumed in a classical Marxist paradigm to be structurally unequal and hence exploitative as a matter of course. In the capitalist discourse, of course, the existence of a labor market implies greater "freedom" for individuals. In practice, both ideologies are poor reflections of reality. Cubans were quick to point out the ways in which working for the state often felt exploitative. And under capitalism, existing social structures characterized by an unequal distribution of opportunity generally consign persons to certain classes of labor.

The labor market produced in the world of Cuban invento did not fit comfortably into either paradigm, neither in the ideal nor in actual practice. While workers and employers were inherently "competing" for the limited resources produced through their inventive efforts, the exploitative tendencies of employment were kept in check by the logic of competitive solidarity - in everyday economic praxis as well as in performative acts.

Alexi, a quiet young man, sold fruit on the east side of the plaza, in an area that was relatively far from the portico and hence received less foot traffic. He worked for Humberto, a produce investor who operated four tarimas in the agro. Some days, Humberto wouldn't show up and relied on his workers to manage the business, arriving only at the end of the day to settle accounts. Yet far from complaining, Alexi spoke generously of this arrangement and the "freedom" he felt because of it. The boss knew that Alexi, like all tarima vendors, bumped up the weight of each customer's purchase by a notch, making a premium for himself on every sale; but, he said, Humberto didn't complain about it. On a good day, in fact, Humberto would add to Alexi's wages a bonus 
roughly in proportion to the tarima's revenue. Once, on a decidedly bad day for business, I stopped to chat with Alexi. He shook his head in misery. "Less than five hundred pesos have come in," he said. "The boss might not be able to pay me the usual salary." I asked Alexi if this bothered him, implying that perhaps it should, that perhaps he should demand his salary anyway. "Well," he said, "I feel bad for him on days like this."

We can rest assured that Alexi was not deluded about his status as a worker. Like many day laborers in the agro, he was quick to ostracize an investor who didn't keep his end of the expected bargain, who had failed to grasp the nature of competitive solidarity. If he sympathized with his boss, this sympathy came from a degree of empowerment.

We've already seen how Carlito related with his boss and close friend, Yoni - a pattern that fits the one Alexi described. On the other hand, such relations did not always match the ideal. In such moments, symbolic performances provided an important mechanism for asserting one's power and publicly displaying the morality of invention in a sort of passion play. On a slow day late in October, Carlito got a mouthful from Yoni in a way I had not seen before. Yoni was upset with the produce he saw on display. Many of the beans for sale were darkened and withered, some moldy, and the usual heap on the table was greatly diminished. Apparently it had not been restocked on schedule. Yoni, who had been gone for a couple of days, felt that Carlito had been irresponsible, that he had made poor decisions about what to acquire from their wholesalers and how much a management task that Yoni often delegated to his friend.

"The problem with Carlito," Yoni said boisterously, loud enough for all to hear, "is that he's nice and loves to chat all day and make friends, but he's a complete moron when 
it comes to business!" He followed this rapidly with a slew of insults and complaints about Carlito's work.

Carlito seemed far less fazed than I by the outburst. I gave him a quizzical look: $I$ thought you were like brothers. He turned to me and, sensing my discomfort, joked in his mock English, which he had picked up watching endless Hollywood films on an illegal satellite connection: “Don't worry. He's a real son of a bitch. I don't listen to anything he says." The vendors around us laughed. Even Yoni, I noticed, suppressed a smirk at the comment.

The more dramatic performance was yet to come, and it came coded in metaphoric terms. Perhaps half an hour had gone by. There were few customers in that time. Carlito and I had turned to a deep discussion about George Steinbrenner's decision to fire Joe Torre, the longtime manager of the New York Yankees — the sort of American baseball news that circulated quickly among Cuban men. At this, another runner in the plaza interrupted us. He spoke in a slurred voice and I gathered he was fairly drunk. In a heated soliloquy he declared that it was "simply impossible" to get rid of someone like Torre, "someone who gave so much to his team, someone who took his players to the postseason as much as he did." His voice rose and everyone in the aisle, including Yoni, was listening now. “How could he? It's simply inhuman! You can’t treat people like scum!" He paused to breathe, and then went on. "Let's say I own a tarima here in the plaza and you work for me, and you're a hard worker. But now and then you take a hundred pesos for yourself. I can't fire you, I can't complain! I have to recognize that what I earn, thanks to you, is much greater than what I lose.” 
Having, at first, missed the performative point, I blurted out: "Ah, that might be the law of the agro, but it's definitely not the law of the major leagues." Carlito glanced over at me and laughed, as if to say, "Silly American." The others laughed as well, Yoni among them. This passion play from a tipsy peer was not about baseball anymore but about the morality of invention. The runner had a message for Carlito — "we've got your back" — and another for Yoni — "your workers are more than 'human resources,' they are brothers and sisters, my friend."

One more aspect of competitive solidarity as I am using it deserves attention before moving on. What is "competitive" is not only the strictly economic sphere, but the building of solidarity itself. Frequently, the social relations on which one drew to successfully "invent" were themselves the subject of competitive pride. A specialty vendor at Cuatro Caminos with whom I developed a close relationship exemplifies this point well, and it deserves development in an extended narrative.

Eitan had been working at Cuatro Caminos for fourteen years, practically since the agro had opened. In the early days he had a typical tarima and sold staples like peanuts and chick peas. Eventually, he began specializing in more pricey products. These were fruits such as grapes, pomegranate, bitter peaches and custard apples, many of which have significance for santeros. Eitan was blunt when I asked him why he focused on such produce: It makes more money. On the other hand, it required extra effort and a wider range of friends and social connections. You could not simply wait in the courtyard every morning for such products to be delivered by truck, even when they were in season, because they were rare and not of significant nutritional value. As a result, Eitan usually 
spent two or three days a week away from the market, travelling to the country on his own, hopping from one form of transportation to another, and hauling back small quantities of produce in sacks he hauled in his arms and a crate he held on his shoulder. Vendors like him called themselves "jaberos" (bagmen), but most jaberos were intermediaries specializing in small quantities of produce. As a result, they did not have their own retail space in the plaza. "You have to be strong and smart to do what I do," Eitan used to say in a raspy, melodic baritone. He was not particularly boastful when he said such things. Just matter-of-fact.

When I got to know him, grapes were in season. He sold only a few bunches a day, for twenty to twenty-five pesos a pound, depending on their quality. This was a markup of as much as 150 percent over what he paid to his suppliers in the countryside. Eitan took pride in the fact that he could operate a tarima in such a niche business that allowed him to leave the city and spend so much time "away from the office," so to speak. But he could only afford to do it because he shared his space with other specialty vendors, an informal system they devised on their own over time. Eitan was nominally in charge of the space, but he split the daily fees with others who sold alongside him. He also kept them in check and taught them the ropes.

While Eitan talked tough, he did not like to get in trouble with the agro authorities, often saying he had not had to pay a fine in all his years at the market. On one occasion, he scolded a young seller in his 20 s who, late in the morning, began arranging pomegranates on the stand. Eitan urged the young man to declare his produce with the 
market manager. Tell them you have pomegranates, but tell them it's half as many as you really have.

The young man shrugged. "Why should I bother?" he said.

"So they don't give you a hard time, boy," Eitan replied. “After that, they'll come and try to start something with me and I'll have to tell them, 'I don't know anything about that guy, I don't have anything to do with him.' ",

Eventually, the young man relented and sought the declarations page for his produce. The message that Eitan, as an agro elder, was sending in this instance was not radical. Rather, he was suggesting that one needed to operate within the system in order to adequately circumvent it, and to operate in tandem, tending to one's solidarity relations, if their mutually beneficial relationship was to last. He liked to say that of all Cubans, it was country folk who had figured this out the best. He was not alone in telling me - I heard it many times — that there were "millionaire" peasants in Cuba who lived quietly in modest homes, surrounded by ten acres, with several cars and trucks to their name. They had nice furnishings, Eitan would say of these country folk, and they lived well. But they were generous to whomever came by and weren't ostentatious, like those young sons and daughters of party leaders in the city. Verifiable or not, narratives such as these deployed at key moments made sensible the contradictions of the market, such as never failing to declare one's produce, while also never making an honest declaration, or using access to a tarima in ways the system did not intend.

On an overcast day in mid-August, Eitan invited me on a daylong trek to the country to pick up grapes for his stand. We met at the market at 9 a.m. and took a city bus to the 
edge of town. There, we waited for a private passenger truck that offered five-peso rides on a regular route into the outer province of Havana. We talked as the truck bumped through towns and fields for more than an hour. We got off in Melena del Sur, about thirty-five miles south of the city, and shared shots of cheap rum at a small private bar. Then Eitan introduced me to a family of butchers who sold home-cured meat out of a window in the alleyway next to their house. He had gotten to know them over the course of his travels and often bought meat from them at discount prices. He would bring some back to his tarima, another mark of his distinction as a master of invention. We had a snack there and more rum, then began a half-hour walk down a dirt road to our final destination.

Along the way, Eitan told me with more than a little pride about the farmer we were about to meet. They had become friends years earlier after meeting at a nearby pub. The farmer, Lucas, shared a few drinks with Eitan and decided on the basis of this scant interaction that he was a trustworthy fellow. You ever sold grapes? the farmer asked. No, Eitan replied. Well, you should, Lucas said: It could make you rich. Lucas invited his new friend back to his home and handed him a free box of grapes. Go back to town and sell these, he insisted. "I thought, why not?" Eitan recalled. "I took them back with me and, man, I sold them all in one day!” Eitan has been buying from Lucas ever since.

But "buying" oversimplifies the kind of exchange they practiced. When we arrived at the farm, there were a few other clients, men and women, sitting calmly under a broad tarp in the back yard, set up next to a shed near the vineyard. Clearly they were on close terms with Lucas and his sons, three of whom were hanging out and moving crates of red 
grapes about. Each client was selecting his or her own grapes from dozens of piles, culling the ones that were rotten or overripe, and eating others. Lucas himself gave me a bunch of grapes to try, and I ate while helping Eitan select his produce. "This is what I like about doing business here," Eitan told me. "It's not impersonal. We talk about all kinds of things, have a good time, I get treated like a member of the family." Lucas knows Eitan is loyal and allows him to make sure he's getting the best crop. Anyway, he told me, the leftover grapes do not go to waste. He uses them to make several bottles of bootleg wine at the end of each season and shares many of the bottles with his best clients as gifts over the end-of-year holidays.

We left with forty pounds of grapes at nine pesos per pound. With minimal transportation costs, the day's work was decent by Cuban standards, but hardly "capitalistic," as such informal practices in the invento market were derided in the state press. By business standards, Eitan had to invest not only money but a substantial amount of time into this work. On the other hand, he was doing something he enjoyed and did not think of his regular trips to the country as work, per se. Many times on the way back, as we continued to take sips of rum from a plastic bottle, he insisted that he wasn't doing all of this with an eye toward becoming rich or expanding his business. It was about enjoying himself, eating and living as well as he could under the circumstances, without having to work for the state or anyone else. His relationship with Lucas was defined by the commodities he acquired but built around a principle of competitive solidarity. Sometimes, he told me, his friends on the farm would ask him to bring them certain products from the city, like bulk quantities of imported rice, which are hard for them to 
come by in the country. So Eitan would bring his friends one hundred pounds of Vietnamese rice, skimmed off the top of deliveries otherwise destined for the state's bodegas, and charge them little or nothing. And maybe, he said, he would also throw in a few mangos for free if he happened to come by them on a slow day at the agro.

Eitan practiced this work, then, in the interstices of something like what Altman (2009) has called a hybrid economy, or what I have referred to as a subaltern market of invention. Structuring Eitan's praxis were alternate and opposed "regimes of value" emphasizing gift exchange on one hand and commodity exchange on the other. Like with so many other Cubans, the tension for Eitan was resolved by "giving up" — on capitalism as much as communism, because neither adequately made sense of his daily experience. He carved out between these regimes of value an existence that strategically "stayed out of politics" in the popular Cuban sense of the phrase. While enacting certain socialist ideals he pursued personal financial gain. And pursing financial gain sometimes required making tough, self-interested choices. Once, he said with sorrow, he fired his own brother and son, who had been selling in the plaza with him: because he caught them overcharging his best customers.

In this way, Eitan's everyday activities provided a diagnostic on the influence of the state and, in their own small way, widened the gulf between the state's bureaucratic ambitions and their actual reach. The relatively free-wheeling context of the farmers market provided for Eitan a sufficiently ambiguous arena in which to sustain such tension and employ it toward ends that were both symbolically meaningful and socially and materially productive. As Altman suggests, it's not as if any particular exchange 
mechanism at work here could be easily categorized within one realm or another — state, market or traditional. What matters in fact is that they bring these realms into a continual relationship with each other.

In saying this I am not trying to romanticize what was, as Eitan himself said, backbreaking work — work that wasn't for everybody. Nor was he as immune from the harassment of agro officials as he boasted. I saw him on more than one occasion shifting produce around surreptitiously to avoid an inspector's eye. We might see in this shared structure of secrecy and exchange what Abu-Lughod (1990) has called a "diagnostic of power." To the extent that subaltern exchange enables everyday life in urban Cuba, especially among the legions of urban poor who are disconnected from the flow of hardcurrency, it also diagnoses the sense of oppression that, while not immediately visible or readily discussed, remains pervasive. Eitan's agency as a jabero did not allow him to fundamentally change the system in which he lived. But it did allow him to survive within it, with a sense of dignity, a sense of purpose, a sense of self, and a moderate sense of accomplishment. Although he claimed no politics — "I don't believe in capitalism, and I don't believe in communism either," Eitan liked to say — his creative action, his invento, was in the sociological sense thoroughly political, which is to say a de facto assertion of power. The next section explores in greater detail the subaltern politics entailed in the morality of invention. 


\section{Inventing a Political Landscape}

It cannot be denied that the inventiveness of self-employed workers in Cuba has been as much a product of the inadequacies of state socialism (its failures to make good on its economic promises) as it has been enabled by late socialist policy. As many scholars of socialism have pointed out, apparent inefficiencies in the control economy are smoothed over through creative practices that bypass the bureaucratic morass (Berdahl, Bunzl, and Lampland 2000; Burawoy and Verdery 1999; Ledeneva 1998; Stark and Nee 1989; Verdery 1996). This is a key component of the so-called unintended consequences of the system. I have not claimed that this model of unintended consequences is misplaced, only that it does not tell the whole story.

As I suggested in my introduction, the Cuban case and socialist studies more generally deserve a richer account of the "politics of morality" — which is to say, the power struggle occurring wherever the morality of invention, which I have thus far developed in this chapter, finds itself at odds with the authoritative moral judgments of the socialist state.

There are two key points to be made with respect to this struggle. The first is that it transpires almost invariably in terms of the ideology of socialism: The subaltern politics of invention draws on much of the same discursive material as that which motivates the Revolution in the abstract. The second point follows from this one. Because of this shared discursive material, the subaltern politics of invention is intelligible in a broad public way: It is not read as "dissidence" but a part of "life as usual," even as it has real and 
powerful consequences in everyday life. And yet, the overall effect of this twin dynamic is nothing less than a practical cleavage in the lived experience of the Cuban state.

The point that the subaltern politics of invention is framed in a socialist logic by now, perhaps, seems self-evident. But it bears noting if only because it is so often missed in analyses of contemporary Cuba, whether or not the invento market is involved. I am reminded now of a telling incident that illustrates this disjunction between how politics is read on the streets of Havana and how it is read in Washington, New York and Miami.

In February 2008, just days before Fidel Castro was to announce his resignation as head of state, video excerpts of a recent student assembly at Havana's University of Computer Science went viral. The video captured a young man from the central-eastern municipality of Las Tunas questioning Ricardo Alarcón, then the president of Cuba's rubber-stamp National Assembly, who had come to the prestigious school to encounter firsthand the future of the island's information technology. Alarcón was rather embarrassed when the student, Eliécer Avila, posed a number of pointed questions in careful language. Why do we need an exit visa to leave our own country? he asked. Why do toothbrushes cost three days' wages? Why is so much of the economy now focused on divisa exchange, when ordinary Cubans have access only to moneda nacional?

With Internet access extremely limited in Cuba, the video quickly circulated from hand to hand on digital flash drives, and there was talk about it on nearly everyone's lips. The video also made a splash overseas. $\mathrm{CNN}$, the $\mathrm{BBC}$ and other major international news organizations picked it up and posted it online; several versions remain on YouTube and have received tens of thousands of views. The foreign press focused on the 
affront to the system implied in Avila's questions. Given Alarcón's important position and the exposure this student was sure to experience, he was portrayed as brave, even heroic. The implication outside of Cuba was that this video had gone viral on the island precisely because of its oppositional nature. The many habaneros I spoke to about Avila's questions didn't quite see it this way. The exchange was interesting to be sure, in that Avila had the conviction to debate such issues with a government leader. But how he had posed the questions, the efficacy of the performance - his clever inventiveness with language — is what made this exchange all the more interesting to Cubans, and, what's more, generally open for public consumption.

I first saw the video of Eliécer Avila, still remembered as "the boy from Las Tunas," in the living room of Mateo, a cuentapropista who fixed cars and sold auto parts out of his home, not far from the Cuatro Caminos agro. Mateo was a member of the same Christian fellowship to which Abel, the bike shop owner, belonged, and shared much of the same work ethic. He was thoroughly fascinated with Avila's disruption of the usual frame of such state-orchestrated events. His wife, coworkers and neighbors gathered around to watch the discussion on a videotape that Mateo had borrowed from a fellowship member, and everyone got hearty laughs out of it.

Having watched it several times together, it became clear that the humor, from a Cuban perspective, was not in the directness of Avila's questioning but in its subtlety. The frame of the state-sanctioned student assembly was not so disrupted in the final analysis. When Avila rises from an audience of hundreds to address Alarcón, he presents himself humbly, in the exaggerated accent of an Eastern campesino, and begins (without 
even a hint of irony) saying: "Well, dear, dear Alarcón. You see, I have a very clear principle, and it's that we revolutionaries don't like to lose — not even some would say when it comes to baseball." Avila introduces himself thereafter as a student leader in the Political and Technological Surveillance Project, part of a state education campaign that monitors and responds to online commentary attacking the Revolution. When he questions travel restrictions on Cubans, he asks why he can't visit important historical sites, for example, where Che died on the battlefield in Bolivia, or the places Fidel and Martí traversed in exile. When he raises the question of government accountability, he asks why it is that the Council of Ministers doesn't make more visible public declarations or deliberations. Why, he asks, should I have to learn about all the new bus routes established in recent months (widely seen as a positive development) from "some guy on the street" instead of a proper news bulletin? As Mateo and his friends and family saw it, the language of Avila's critique was consistent with a recognizable authoritative discourse, and it paid due respect to the master symbols of the state: Che, Fidel, Martí, the Revolution, and socialism itself — all the guarantors, in principle, of true freedom and well-being. Despite acknowledging Avila's "critique of the system," the real loser in the performance, in their view, was not the state in the abstract so much as it was, personally, Alarcón.

Certainly this exchange could not in its entirety be aired on state TV, such was the extent of its disruptive framing. But it's also true that the government - unlike in the case of censored dissident writing — could not ignore the video and the fact that so many people had seen it and were debating it. Avila himself appeared on state television within 
a few days to clarify that, of course, he was thoroughly supportive of the Revolution and that his questions were intended in solidarity with his country. Interestingly, his tone has since changed. Avila left Cuba a few years later, claiming that state security agents had threatened him and his father, and now counts himself among a number of Cuban-born bloggers and activists working to "negotiate a more democratic way forward" with the socialist state. Notwithstanding Avila's personal trajectory, my point here remains: Avila's newfound radical activism has not generated nearly as much interest in Cuba as his original critique, rehearsed in the modality of a subaltern politics. His original critique, in playful language — inventive yet recognizable — engaged a politics of morality with which ordinary Cubans could identify.

Knowingly or not, what Avila accomplished with his address to Alarcón was a reworking of the state's discursive frame. This episode serves as a good analogy for the more prosaic reworking of the designs of the socialist state that occurred daily on the streets of Havana in the invento market. This reworking, to be clear, does not obviate the regime's often repressive police tactics, as the subsequent course of Avila's life illustrates. Rather, it displaces them onto a distant experience of the state, known to be capable of affecting one's life but acting mainly on distant subjects, imagined others: dissidents and other social outcasts. At the same time, this everyday reconfiguration of political power draws a more intimate realm of state agency closer, directly into the personal lives of social actors. In this more intimate experience, via the logic of competitive solidarity, Cubans employ the state's discursive (ideological) and productive (economic) resources to their own inventive uses. The circulation of the video of the boy 
from Las Tunas was itself one such project. It both affirmed the distant state and instantiated the intimate one.

This then is the "cleft state" to which I have referred. Its distant form, like the "spectral state" that Mueggler (2001) has described in a rural Chinese context, is a ritualistic power imagined to have panoptic properties, to which a ritualized response is demanded. In Cuba this form of the state is symbolized in ubiquitous billboards bearing the words and images of Fidel and Che, and enacted in May Day parades, nightly TV dramas and official historical commemorations.

In the next chapter, I take up this distant state and its moral politics in greater detail, showing how it is experienced in everyday life. First, however, we must examine what I am calling the intimate state. This is the experience of the state produced in the invento market and through the moral landscape of Cuban inventiveness. The ethnographic data on which I rely to develop this concept consist of the myriad ways, some already referenced, in which state agents and enterprises are drawn into everyday entrepreneurial activity and so encompassed. Accordingly, the remaining sections of this chapter analyze, in turn, this reworking of the state's discursive and productive resources, and those encounters with the state which enable the production of an intimate, subaltern political landscape.

\section{Intimate state: A discursive resource}

The boy from Las Tunas for a brief moment seemed to be the every-Cuban. As we have seen, he critiqued the abuse of state socialist power on its own terms and so his words resonated in a way that absolutist dissidence never could have. His appropriation 
of authoritative discourse was so understandable in part because, in the invento market, it's an indispensable tool for justifying and making sense of everyday life. Seemingly invisible most of the time, it would crop up in everyday language at crucial moments and in subtle and telling ways.

Throughout the city, bits and pieces of this discourse were strung up in public displays and artwork, with no advertising to compete with them, available as it were for the taking. The plaza was no different. Painted on the corridor between the tarima area and the center courtyard was a crude portrait of a middle-aged Fidel Castro in military uniform alongside the Cuban coat-of-arms and two versions of the national flag. At the top of the wall a sign read "Historic Area." Beneath the picture of el comandante, in small cursive type was an excerpt titled "Concept of Revolution," taken from one of Castro's famously long speeches. Many phrases of this speech were scattered around Havana on signs and billboards, and about halfway through my fieldwork quotations of the same text were installed in the tarima area on large, bold placards.

I often felt like I was the only one reading such propaganda, it had so faded into the background of daily life. As Gropas (2007) has noted, the ideology of this "mnemonic landscape" has become increasingly nativist, less obviously concerned with a MarxistLeninist vision of state socialism. And I would add it has become more and more selfreferential and tautological in the manner of the authoritative discourse of late communist Russia (Yurchak 2006). One of the quotes often drawn from the "Concept of Revolution" speech, for example, is that revolution means to "change everything that should be changed." And yet, despite the physical and ideological deterritorialization of these 
discursive materials, I found that they are not at all irrelevant. Even if ignored in a performance of that practiced indifference which I have said is so pervasive in contemporary Cuba, these bits and pieces of revolutionary ideology remain in the backdrop of life, reminders of the distant state. Hang out with self-employed workers long enough, I found, and traces of the distant state reappear, reworked, in the market of invention.

Not long after the placards of the "Revolution" speech showed up on the rear wall of the plaza, I asked Carlito what he thought about them. He ignored the question at first, or maybe just played dumb. Then, acknowledging me, he acted like he didn't know what I was talking about — until I read the quotes out loud, one by one, and pointed to them. Even then Carlito insisted he hadn't noticed them, huge though they were. Now that he did, however, he shared, unprompted, his favorite one with me. It said that revolution means "to struggle with audacity, intelligence and realism." "Yes, sir," Carlito said. “That's what we're doing here in the agro. We're making revolution. And that's what Cubans are doing every day, 'struggling with audacity.' " I asked him to explain that phrase to me, in his own words. He described how he let one of his better customers pick out bad beans, then bring them back to the tarima and sell them back to the store, ounce for ounce. This trick increased the total percentage of bad beans for other customers, but this gentleman, Carlito said, was steady and dependable, and he felt sorry for him; he was old and very poor. "That's struggling with audacity," Carlito said.

The term "struggle" — so associated with class struggle, in the Marxist sense — in Cuba is rendered as luchar, in the verb form, and lucha, as a noun. La luchita ("the little 
struggle") is a term closely related to invento. If invento refers to the creative process by which one survives in the Special Period, la luchita is what happens when inventive practices are deployed in the real world, where they must contend with restrictive policies, marginalization or oppression. When you ask how someone is doing, a common answer is, "There — in the little struggle." Or, simply, "Struggling, my brother." While these might seem like responses that index a sense of being downtrodden (and they often do), they may also carry a positive valence, every bit as positive as authoritative uses of luchar. Its everyday invocation could easily come with a smile, a smile that says, paraphrasing what many told me: "I'm struggling because socialism is a struggle, and by calling what I do a struggle, my invento is no less significant, no less acceptable, than the larger struggle to build socialism."

Many self-employed Cubans came to Havana from other provinces because in the city there was far more opportunity for gainful employment, but the government, fearing overcrowding, had made it illegal to "transfer residence" to the city without the proper approvals and paperwork. Consequently, Eastern migrants were discriminated against on the basis of speech patterns, dress, mannerisms and race (habaneros claimed they were "blacker"). Seen as suffering a kind of internal exile, they were referred to, colloquially, as palestinos. Their everyday struggle, palestinos said, was not only finding income but being able simply to stay, as they often faced harassment and the threat of deportation when stopped by the police. A common refrain to repeat against the cops in such instances, a version of which I heard from an agro vendor named Mariano, was identical to a government motto seen at all the major gateways to the city, in bold letters: "Havana, 
the capital of all Cubans!" Mariano told me how he used this saying effectually to argue with the police during a traffic stop, while he was traveling back from a visit with family. He was telling me this story when a tarima neighbor, his friend Lidia, interrupted us. She announced that she had an even better story. Once, Lidia told us, she was stopped by a police officer because she was wearing flashy pants with an American flag painted down the legs. Clearly, the apparel was not something you could find in Cuban stores and had been obtained by way of some invento or another. This implied that Lidia was a woman of connections, connections stretching to Miami perhaps, and, therefore, a woman of some means. It was the late 1990s, she recalled, before the CUC had been introduced; the U.S. dollar had already been legalized as a "drastic measure to struggle against the blockade" and was circulating freely. In Lidia's view, this fact made the police officer's alleged concern for what she was wearing all the more outlandish: "You can't wear these pants," he told her sternly.

A palestino like Mariano, Lidia sensed this officer was after something — having no solidarity with her, he was trying to scare her to extract some personal gain. This is theft plain and simple! she thought, replying, "And why can't I wear these?”

"Just look at them," the officer said. "This supports the enemy."

"Oh yeah," she said, exasperated. "And what about this?" She dug her hand into her purse and pulled out a one-dollar bill and stuck it in the officer's face. "And who is this on this piece of paper? José Martí? Aren't these divisas OK to have now? So now you see, these pants are a drastic measure I've taken to struggle against the blockade." Of course, Lidia told me, laughing at her own ingenuity, she was also saying that this was all 
the officer could hope to get out of her: one dollar. By now, as she recalled, a crowd had gathered in her support and was clapping. The performance had been perfect. The cop left her alone. "What else could he do?" Lidia asked me, and turned to Mariano, beaming.

Not all appropriations of authoritative discourse were so confrontational, or so literal. Most were much more subtle; some of them involved no words at all but objects of symbolic importance. José María, a divisa bookseller I knew who worked in a tourist district, always kept on hand a copy of the commemorative edition of Fidel Castro's official memoir, published originally in serial form under the title One Hundred Hours with Fidel. I learned why when José María first pulled out this bound volume and tried to sell it to me. The proposal seemed odd and out of place when he made it, in the middle of an unrelated conversation. José María had been telling me about some of the inventive that is, illegal — aspects of his business. I looked at him puzzled but he ignored my look and kept on talking. About the book, he said out loud, "It's very interesting stuff. It will tell you everything you want to understand." Then he jumped topics again, regaling me with details of the Cuban national baseball championship series. Later, I asked José María about this strange behavior. He explained that he had noticed an inspector hovering nearby: It's always good if they see you promoting Fidel's work, and I don't want them to know about all my inventos. "So, you were just saying that, about Fidel's book?" "Oh, no," he replied. "I meant that. It's very interesting stuff. As I said, it will tell you everything you want to understand." 


\section{The intimate state: A productive resource}

Some have suggested that because Cubans have become accustomed to "stealing from the state," popular culture has as a result experienced a general corrosion of morality under socialism. This reflects a superficial reading of the present context, and relies on ethnocentric thinking that presumes a universal "morality," and a crossculturally stable set of categories on which to evaluate moral action. Late socialist subjects involved in the invento market indeed made a clear and significant categorical distinction between that which is undeniably "theft" (robo), and that which constitutes an acceptable way to resolver. To be sure, there were disagreements over the boundaries of these categories, but not that they existed in the abstract. Also, this situation is complicated by the fact that appropriating material resources from state enterprises - a near universal practice among state workers — was in the legal and technical sense known to be a form of "theft." Thus the terms referring to the underlying categories of robo and invento could converge at times on a single morphological utterance, such as "theft," and create the illusion of categorical sameness. I learned quickly that whenever my interlocutors spoke of "theft," I had to take note of the context and delve deeper, asking: What kind of theft? Was this invento, or robo? Whose perspective was being invoked?

From the perspective of the distant state and its authoritative discourse, invento is almost always a form of indisciplina social — part of a panoply of threats to state socialist solidarity, including drug use, violent crime and prostitution. Cubans were constantly being urged to stay "vigilant" against such ills and reject them. But from the 
invento perspective, however, state agents themselves could be a deplorable source of “indisciplina," i.e., if they failed to conform with the morality of invention. Lidia's anecdote above has already illustrated this point. She had no relations with the police officer who stopped her on the street. And in her view, he therefore had no moral authority, in spite of his badge and his uniform, to make a claim on her interests. To exact a bribe from her in this context would amount to theft, "plain and simple," as she put it making this an intimate encounter with the state of a particular order: in this sort of encounter, discursive invention serves to mitigate "things that should not happen."

But state encounters of this adversarial kind, whether dramatic as with Lidia and the officer or muted as with José María and the inspector, were but a subset of the ways in which subjects acting in their capacity as agents and employees of the Cuban state were drawn into the intimate sphere of inventiveness. In the morality of invention, theft from the state and apparent collusion with its representatives — insofar as such actions meet the features of the code as I have described it (competitive solidarity achieved through reciprocal exchange) — are not only permissible but prescribed. Not following this rule can be morally dangerous.

So it was that Paco, the handyman, had a friend at a gasoline station who sold him fuel on the left, which he then provided at no cost for another of his regular clients, a Venezuelan military man who was residing in Havana at the time. Each of the actors in this triad, having already established relations operating on the morality of invention, felt the other obliged (and himself willing) to do his part. So it was that Abel offered a twenty-inch tire to a new inspector, once he had sized her up as trustworthy, and saw in it 


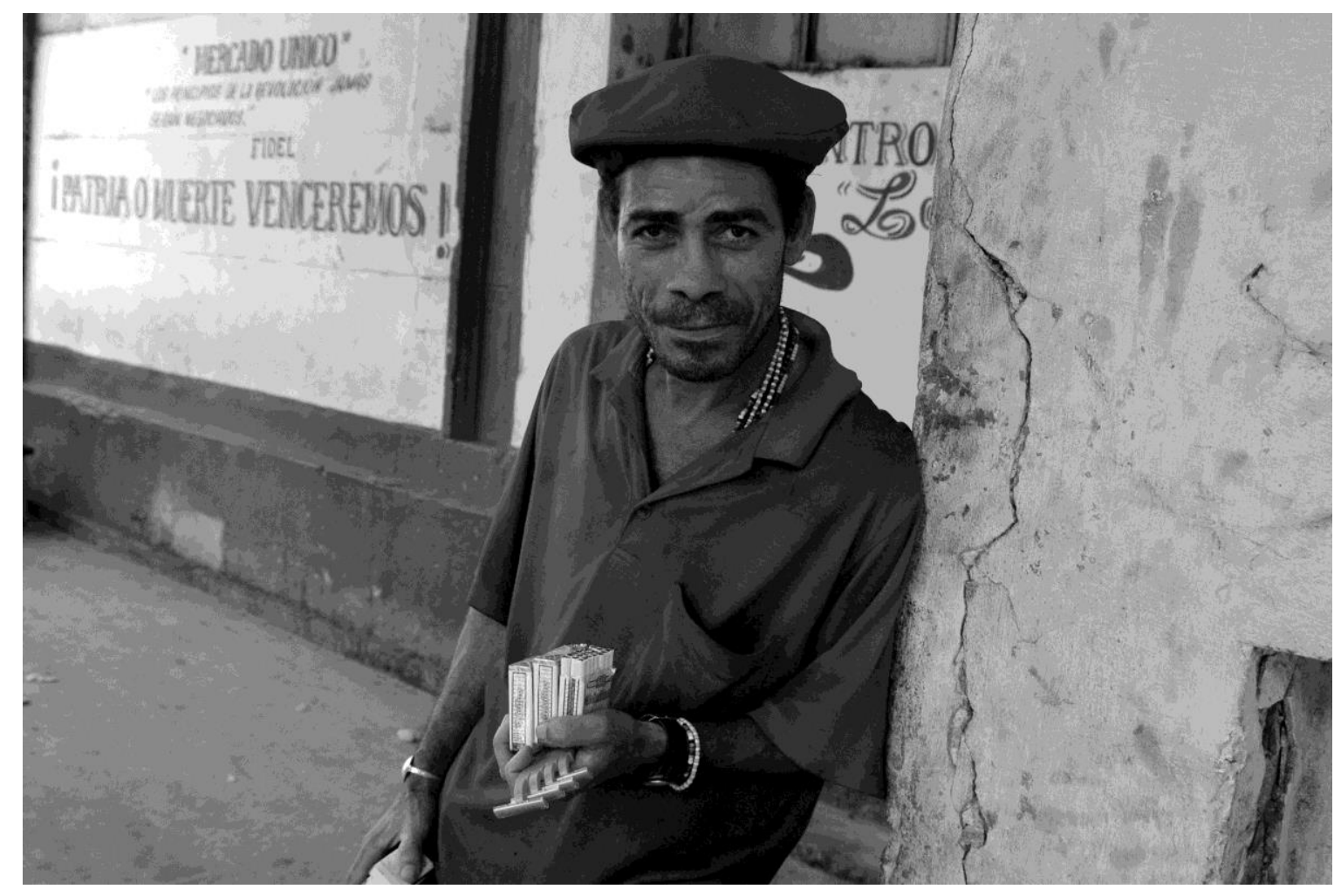

\section{PHOTOGRAPH 3.5}

A merolico and his wares. Behind this roving vendor, state slogans grace the market wall.

no moral contradiction, with his Christian philosophy or otherwise. And so it was in the case of a street-side merolico (a roving vendor) just outside the plaza who liked to chat me up. Victor was a disabled veteran of Cuba's military campaign in Angola and peddled an assortment of music. One day I saw him give over a CD to a young cop with whom he was friendly, a man who Victor said protected him "like a brother." "I don't always give him things like that," Victor explained, after the police officer took his leave. "But I know he likes that band. Anyway, he has a CD burner at home that he lets me use sometimes. Tonight he'll burn the disc, and tomorrow he'll bring it back to me." 
Such relations at the plaza abounded, and worked in multiple directions. Agro administrators could also call on their vendor friends to abide by certain rules at certain times, on the premise that they were, in effect, key nodes mediating between the distant and the intimate workings of the state. Teresita was one of many unlicensed roving vendors who sold boxed lunches, cigarettes, coffee, razors and other small items from agro to agro. Her specialty item was a one-peso swig of heavily sweetened espresso that she poured from a large thermos. Teresita liked to say that it was easy to tell administrators who were jerks from those who weren't, in how they talked to you. A nice one would say, 'Look, don't sell coffee right at this moment, we're in the middle of a general inspection," or, "Please, now is not the time to be in here. Go in the portico and see if you can't sell there for a little while."

Such relationships were not limited to the sphere of Cuban pesos. Lourdes, the divisa landlady, made regular payments to an inspector from the immigration office, part of the Interior Ministry. The inspector, Alfredo, was assigned to check up on her rental property and collect information about tenants. He knew well that Lourdes (like most licensed renters) did not in practice follow the letter of law, and understood why. As Henken (2002) suggests, in the hard-currency "bed and breakfast" business it was nearly impossible to break even without such arrangements. But rather than viewing themselves as "condemned to informality," that is, engaged in a nonstandard, sub-optimal market, I found that landladies such as Lourdes accepted these arrangements, including the payments they felt obliged to make to the inspectors who signed off on their work, as the appropriate functioning of the invento market. This was the usual course of things and, in 
their view, important to maintaining a competitive solidarity that might otherwise be put at risk in times of economic uncertainty. Lourdes, as we have seen, understood her good fortune not as hers alone but "of her people" — and this sentiment extended even to the housing and immigration officials in her circle of confidence. It drew them into the invento market and implicated them in its moral landscape. "I'm going to tell you something, Robert," Lourdes once told me soberly, the way she spoke when she wanted to draw my attention to some elemental datum. "I'm telling you this so that you know how it is we justify certain things. I see these payments as normal, as part of the system — these are the pathways that we have found in order to resolver a life for ourselves. That's all that Alfredo is doing. And that's the way it is. We're helping each other out each of us for each other."

This sentiment was especially true for workers at state enterprises who had access to relatively valuable goods and services, like the security guard who was Adela's friend, or the trusted connection who made the state carpentry workshop available to Dante, the cigar-box craftsman. Furthermore, there was no question that the cigars that would fill those boxes and the thousands like them sold in tourist fairs had been swiped ("resolved") from the floor of a state tobacco factory. The process was explained to me many times by many different prospective sellers. This tobacco, they insisted, was of the finest quality — you could be sure of this fact, because it was selected and absconded from the workshop by the rollers themselves, with the help of their supervisors and, probably, their supervisor's supervisors. That's why these cigars have the official seals, which were also absconded. Even the most stalwart of party hacks and delusional "militants" of the 
neighborhood Committee for the Defense of the Revolution understood and accepted this routine. A plaza vendor named Rivero, who sold avocados, was among the most ready to defend the Revolution in its own authoritative terms. He used to say that his younger peers, like Carlito, lacked “political culture” because they didn't recognize "what they had here," they didn't see that "they are living in the best country on earth, a paradise," or that the difficulties they faced were the cause, mainly, of a murderous U.S. foreign policy. "And to think so many of them are trying to leave!" Rivero would say, genuinely filled with sadness.

But one day, we went for a walk to get some lunch and he confided to me that he might drop his tarima. He was an engineer by training and had learned of an opportunity to work at a construction firm operating under one of the ministries.

"Wouldn't you make more at the plaza?" I asked. "Won't you have to continue working there on the weekends anyway?"

"Look," Rivero said. "You have to take into account the benefits of working for the state. Let's say I work in the machine shop making parts for cars. I have access to materials and a norm I have to produce. If I can stretch out supplies to meet the norms and then find some time, during lunch, after hours, during a break, I work on side jobs for me and my compañeros."

In Rivero's view, the intimate state gave to the people who willingly gave to it, who competed with its interests in genuine solidarity. Having state employment allowed you to get by appropriating from the enterprise whatever you felt you needed, or what you could to help your friends — but not more than that; there was a limit, in principle, to the 
generosity of this intimate state. In telling me all of this, Rivero made it absolutely clear he was not criticizing the system, denying that his hopes to work in construction tarnished in any way his professed "militancy." On the contrary, and much to my surprise, he was using the possibility of this job as an example of one of the many benefits of state socialism: "Here people make millions thieving from the state. So they shouldn't complain about things so much. Over there, where you live, if you steal even just one avocado from a capitalist, he'll throw you out the door!"

\section{The reinvented state}

The intimate state is a state reinvented. I began this chapter with the claim that the morality of invention makes possible a political struggle with real effects. In the last two sections I have elaborated how these effects take shape in the market of invention. But these intimate reinventions of the state are not limited to patently market transactions, or to the cuentapropistas with whom invento is most associated. They spill over into other aspects of life, enabling, in a kind of feedback loop, inventions of a second order, also relying on the ethos of gift exchange. I witnessed such processes play out especially in the bureaucratic machinations that reinvent one's dealings with the intimate state, in everything from my own visa renewals to residential property transfers, producing in turn "affective relations" toward the state, as Gupta (2005) has found in India. For example, I knew of many cases in which faux marriages were arranged, with the tacit knowledge of the bureaucrats who approved them, so that a home could be passed on (sold, probably) to one's "spouse"; or in which foreign connections were used to gain access to a coveted dialup Internet connection; or in which official paperwork was fudged to enable one's 
claim to Spanish citizenship — a claim that might greatly improve one's chances of overseas travel or immigration. Not all but a great many of these cases involved no obvious monetary transaction or the movement of valuable material goods of any kind. All of them were justified and explained in terms of the concept of solidarity.

I knew a retired sailor, Tico, whose story provides a good illustration of the everyday reinvention of the state. He was the neighborhood drunk on the block where I lived with my family in Vedado, a part of town known for its majestic but neglected facades. Many upper- and middle-class professionals had moved there, escaping the more congested downtown areas, in the 1940s and '50s, and though the buildings were suffering, their once-vibrant paint chipping away, it was still a desirable and quiet place to live, with shady trees and parks arranged every half-mile or so. From a peasant family, Tico probably never could have lived in a place like this had the Revolution not changed the course of his life. As a young man he joined the Cuban navy and served time at sea. Later, he traveled the world in the Cuban merchant marine. For his many years of service he received the right to a tiny studio apartment — his hovel, he called it — at the end of an alleyway not far from our apartment.

When I met Tico he was not especially well, physically or emotionally. His only son, Felipe, had left to Miami; Tico had tried, and failed, to obtain a visa to go visit him. (I helped prepare Tico, in vain, for his interview with immigration authorities at the U.S. Interests Section.) At times, he seemed the happiest of souls — often this was whenever we gave him some way to offer a helping hand. He derived great joy from shimmying up a palm tree in our small yard, barefoot, to recover the coconuts hanging precariously from 
it, lest they fall on our heads and kill us. He never accepted a dime, for this or any other service, nor however did he decline a cafecito in the late afternoon or the chance to chat. At other times, late at night, he showed up drunk and filled with grief, talking about the end of his life.

Felipe was bothered that his father didn't want to use some illicit means to leave the country. Tico refused because he had no intention of staying in Miami if he could get there, as his son wished. "He's mistaken about me," Tico told me one night. He said he only wished to visit, to see his son one more time and to meet his daughter-in-law once before he died: "I can criticize things here and say that there are problems. But I struggled over forty-some years of my life for this system, and let me tell you, now the system owes me something. And maybe I go over there [to the United States] and I have more things but I'm less content. I prefer to be here with less, but more content. Here, everyone knows me. I go to such-and-such a place, let's say the bodega, and the old man who works there greets me and says, 'Tico, what do you need?' And whatever I need, he helps me out. But I don't abuse it. I'm not one of those people who asks for much. I give. I give because giving pays later in other ways..."

What troubled Tico more than anything was what might happen to his hovel after he died. He was close with Coralia, a neighbor in another apartment in the alleyway, the subdivision of a once stately house. Coralia was in her 50s and occasionally worked as a private tutor. She had a son in his 30s who lived overseas, in Spain, and he sometimes sent remittances; another son lived at home, and as far as I could tell mostly watched baseball on TV with the family patriarch; and a daughter in her early 20 s who was 
studying at a local technical school. Tico had seen this daughter, Yulima, grow up. Now Yulima was pregnant, and she wanted the father of the child to move in with the family, but the space in the home was already extremely tight.

For years, Coralia had looked after Tico and invited him to meals and to play dominoes in the alleyway, and he fetched things for her from the bodega when he could. If there was one thing in the world Tico could do before he died, it was to find a way to formally pass his hovel on to Yulima, in a gesture of kindness and solidarity. He wanted no money for it, but realized it might take money to accomplish. He had saved a little bit of cash for some time, from the funds Felipe would wire whenever he could. He didn't tell Felipe he was going to use this to buy the right to transfer his hovel to Yulima, instead of for his visa paperwork.

I found Tico one morning in a better mood than usual, because a lawyer he had "resolved" through his connections was on the way over, to discuss his housing issue. The lawyer was going to plead Tico's case against a housing official who did not want to recognize Tico's right to transfer the apartment to an unrelated person. The lawyer knew of a loophole, and he was friendly with the housing official. He only needed to convince the housing official to exercise a special rule, whereby Tico could make a payment to the state, of several thousand pesos, to control the title however he saw fit. The lawyer would furthermore explain Tico's intentions and appeal to the bureaucrat in a spirit of solidarity. Tico insisted there was nothing illegal about this — it was not bribery or corruption but knowing the right people and maneuvering the structure in a certain way. "A certain kind of invento," he said. Eventually, it worked. 


\section{The People's Socialism}

As the last few examples show, Cubans operating in what you might call the "regular" world of invento, as distinct from the dangerous and "irregular" world of dissidence and political activism, are ready and willing to exert their relative power over state logics in their everyday manifestations. Police and inspectors become complicit in the solidarity economy of invento. The bureaucratic machine is manipulated to the advantage of, not simply individuals (though individuals may benefit themselves) but in support of the networks of reciprocity to which social actors are attached. In this way, Tico was able to give back to his neighbors in just about the only way he could, by bequeathing them the tiny house in which he lived. One might argue, cynically, that this procedure was only possible because of state socialism and its bureaucratic nonsense to begin with. In the Western, ostensibly democratic, ostensibly free-market world, Tico would as a matter of course have been empowered to do whatever he pleased with his house (if he owned it to begin with and, truth be told, with no shortage of our own complex paperwork).

This counterfactual both misses the point, and is exactly the point. On one hand, a peasant-turned-sailor could never have lived in such surroundings were it not for the radical social change wrought by the Revolution. On the other hand, even if he had found fortune in a capitalist world, the Tico of that alternate universe is not likely to have experienced the specific history of reciprocal relations, or the obligations of solidarity they inspired, which in the real world induced his effective manipulation of the very regime that conditioned them. 
This is not a romantic politics of resistance, but a pragmatic politics of invention.

And the conceptual result is not an idealized state socialism but, in a manner of speaking, a humanistic “people's socialism." The people's socialism readily draws on the authoritative ideology but is not in its thrall. It stands apparently in opposition to the distant state, but encompasses as much of this state's everyday methods and processes as it can. Where necessary, it invents and resolves: twenty-inch bicycle tires, faux marriages, so-called indisciplina social. There is a no definite line between the people's socialism and the state's official version; these resonate with one another and are deeply entwined in lived experience. But the distinction helps us understand how ordinary Cubans differentiate, for example, between shameless robo and prescribed invento when devising a clever solution to the problem of getting by on a state salary.

In my introduction, I showed that this situation, while tenuous, is hardly unique to Cuban socialism. It is observable more generally in the history of state socialisms elsewhere, especially in Eastern Europe. As such, this Cuban moment has an important retrospective to offer the literature of socialism and postsocialism, and consequently to a renewed anthropology of political economy, claims that I address more fully in the coda to this work. Laying the foundation for such a discussion requires, first, that we remain on the island to address a paradox at the heart of the morality of invention and the political subjectivity it entails: In the authoritative rather than intimate form, the socialist state has not been especially welcoming of competitive solidarity.

As we shall see, Cuban state ritual practice and its recent economic policies have furthermore encouraged consumerism, individual wealth accumulation and the 
production of neoliberal subjectivities, all to the contrary of Marxist principles and in spite of its increasingly tautological official discourse. This apparent contradiction emerged historically out of a political transition that already has long been complete: the transition from revolutionary praxis and socialist development, to a fully institutionalized and self-referential Revolution. The socialist state has not dissolved, as Marx imagined — but on its present course it may very well become morally irrelevant to ordinary citizens. 
Tienes que ser manso como una paloma y

astuto como una serpiente.

- Cuban saying

\section{The Politics of Morality}

The morality of a given market is inherently political, because market exchange draws its subjects into relations of power with one another, as well as relations of power with the larger social body of which they are a part. This is to assert nothing more or less than the political nature of all human social interaction, highlighting in this case its operation within a particular subset of such action: the "economic" world. And yet it bears repeating, precisely because the modernist cultural project of global capitalism fantasizes "the market" - its core sphere of creative activity — as morally disembedded. Insofar as politics is concerned, political agency is imagined as operating within a separate sphere that "acts on" the market, regulating an otherwise natural process as if the source of all moral logic could only come "from outside" the economic sphere.

But the market of invention in late socialist Cuba, as we have seen, is realized in and through a particular moral landscape, notable precisely because of the ways in which it can be differentiated from the ideology of capitalist markets and the socialist state. I have called that moral landscape competitive solidarity because it is one in which people seek out their material livelihoods such that what "counts" as material already includes, and emphasizes, social relations. Social ties are understood as both means of production and ends in themselves. Competitive solidarity is a moral paradigm forged in the practice of 
everyday Cuban inventiveness, reproduced in relations of reciprocity, and premised upon an affective devotion to one's relations broadly conceived. This morality of invention has political consequences, for it fosters a moral subjectivity among cuentapropistas that we now see is not "emerging capitalist consumer-citizenship" but a shadow-form of socialist producer-citizenship. This "people's socialism" draws historical inspiration from the ideals of the communist project, but is at once a potentially perilous alternative to state socialism as institutionalized in the authoritative praxis of the Revolution. Morality, then, has a specific politics. And the morality of invention in particular finds itself in a political struggle that its practitioners themselves deny.

In the last chapter, we saw how this subaltern struggle constitutes two experiences of the socialist state, which I identified as intimate vs. distant. In the first case, agents of the state in the form of factory workers, business inspectors, police officers, bureaucratic supervisors, etc., are caught up in the workings of the invento market and the relations of reciprocity on which it thrives. In this sense, Cuban inventiveness includes within it an everyday reinvention of the state; the state is thus made intimate. Viewed from another perspective, however, the morality of invention serves also to stabilize its inverse. The people's socialism has real political consequences in that it creates the space whereby an alternative market praxis that is neither "socialist" nor "capitalist" in an idealized form, can be realized. But, not being a politics of direct opposition, this praxis also affirms and accepts by implication a hegemonic discourse, and in fact participates in its reproduction. In this way, the intimate and distant experiences of the Cuban state under late socialism cannot be fully disentangled, even though these experiences play out according to distinct 
moral paradigms. It is to the distant state, its moral logic, and its effects, to which we turn in this chapter.

In doing so, I am reasserting the analytical validity of the distinction I have made between the intimate and distant state as themselves the "effects" of various social dynamics (Mitchell 1990, cf. 1999). This is not the same thing, however, as asserting that they are experientially distinct. On the contrary, it is out of the expression of a persistent moral ambiguity in everyday relations that I have found it necessary to tease out this distinction and explore it. Among cuentapropistas, this ambiguity manifested itself in many ways, often leading them to make seemingly incongruous remarks or provide circumlocutions to explain why invento in general might be morally suspect while their inventiveness was of course all right. One night I was invited to participate in the prayer meeting of the Christian businessmen's fellowship to which I have already referred. Dante, the cigar-box craftsman was a member, and friends with Mateo and Abel, two other informants in the invento market who opened their homes and lives to me. On this night, several members of the fellowship rose to offer life testimonials to the rest of the group, some thirty men between 25 and 80 years of age. Toward the end of the meeting, petitions were offered, asking the others to pray for certain people. It was then, in response to a request for donations of clothing and other basic goods to give to a destitute family known to the group, that Dante said:

It's a very complex situation, that house, and I'm talking generations back. [...] They were always the poorest family in the neighborhood. The mother and grandmother of those people always sold off what food they got from the libreta [state ration card] to buy 
liquor for themselves, and that was when things weren't so hard and you could make a living honestly - well, it's not that all of us aren't honest people, but you know what I mean — back then when you didn't have to invent things to make a living — when you could live comfortably from your salary — that was the situation.

The frame of this discourse is the speaker's evaluation (somewhat circumspect, incidentally) of whether helping the family in question with donations was indeed a good idea. But the reason I highlight this bit of speech here is to draw attention to Dante's offhand remark about the morality of invention. Speaking in public, even in an informal gathering of like-minded cuentapropistas, Dante is torn about how one should think and talk about invento. On the one hand, much of what it encapsulates is potentially "dishonest," as it may involve bending laws, misappropriating public goods, or giving some clients preferential treatment, for example. Yet he quickly corrects himself: Not that we're dishonest, "but you know what I mean." What does Dante mean, actually? His statement hints at nostalgia for "less complicated" times relatively free from such moral ambiguity. But it is at the same time unequivocal about the necessity and moral decency of "our" invento (recall that Dante himself made use of a state-owned workshop "on the left," with the help of his social connections); likewise, the statement is unflinching about the morally reprehensible misuse of state rations at the expense of one's household.

Later, I asked Dante about this remark, and he said he didn't mean to suggest that his fellowship brothers should ignore the hardships of the least among them. Rather, he said, he meant that simply "giving people stuff" (in the modernist sense of charity, not the Maussian sense of the gift) was not the answer. This is what the state tried to do, after all: 
it just gave you stuff. The better choice, he thought, was to get the family involved in some invento of their own, something legitimate in terms of the morality of invention if not in legal terms, and hence reciprocal by definition, to help get them on their feet again. In this way, an offhand remark could encompass a deeply problematic moral struggle, mapping roughly onto the politics of state socialism vs. the subaltern politics of invention. I have called this struggle "the politics of morality," and in this chapter we will explore further its entanglements.

This struggle over the politics of morality is all the more trenchant in late socialist Cuba because - on the authoritative side of the political equation — the kind of subjectivity that the distant state tends to foster is rooted in a range of contradictory moral dispositions that are manifestly opposed to the morality of invention. Already Dante's remark hints at this point, but it deserves a detailed elaboration; indeed, this is the key claim I defend in this chapter. As we shall see, these dispositions are contradictory in at least three ways. First, like capitalism, they are internally contradictory, for they fantasize a consumerist world of plenty and political equality, while producing actual inequalities of material wealth and power. Second, in a related way, they assert the moral premise of possessive individualism, at odds with the competitive solidarity that ordinary people feel to be moral in their everyday relations. And finally, inasmuch as the socialist project historically seeks to dismantle the class struggle of capitalism, foster egalitarianism and work toward a utopian communist society, the distant state in practice contradicts its own ideological discourse. 
Developing my claim about the politics of morality requires that we enter the contemporary operational sphere of the distant state and explore the logic of its praxis, while at the same time never losing sight of the fact that this form of the "state," like any other, comes into being only through the lived experience of its subjects. To this end, I marshal ethnographic data on political rituals and their symbolic constituents, the modernist workings of the state-sector economy, and everyday experiences that reveal a variety of conflicted sentiments aimed at the nation-state and directly derived from the subaltern political struggle that the habaneros I knew faced in their daily lives. In the first section I compare how the sources of authoritative meta-discourse imagine the distant state's effects with how, in day-to-day practice, the "state" and its symbolic projects are experienced both as objects of satire and instruments for effective social action. The second section considers how the changing nature of Cuban macroeconomic policies and practices - in prosaic as well as ritual contexts - constitutes a distant state favoring a modernist subjectivity at odds with the morality of invention. Finally, I consider how this situation reproduces a deep sense of moral and political ambiguity for social actors under late socialism.

\section{State Effects I: Ritual and the Politics of Symbolism}

Because this chapter makes extensive use of the concept of "ritual," it merits some theoretical attention. I use the term ritual in a broad anthropological sense to refer to the regularly repeated formal performance of a shared mythology. Ritual defined as such figures into the apparatus of every human society, and modern states are no exception. 
Beginning in the late nineteenth century, Durkheim brought the study of ritual into the domain of social science, tending to focus on the cohesive function of ritual practice, i.e., its conservative impulse. Turner (1967: 30) succinctly summarizes this notion of ritual as "a mechanism that periodically converts the necessary into the desirable." Ritual is especially effective in this regard, he argued, because its enactment transfers the emotional force of a sensory experience into an ideological one, and vice versa, making one's culturally constructed universe, along with its "dominant symbols," appear as selfevident, reproducing a coherent moral aesthetic. In elaborating this view, Turner (e.g., 1957) also showed how ritual can draw out social conflicts and contradictions even as it sublimates them, pushing anthropology to transcend Durkheim's functionalist paradigm.

In this neo-Durkheimian framework, ritual theory does not take ideologies as existing a priori. It recognizes instead that dominant sociocultural structures are continually reconstructed and subject to transformation in ritual practice itself. Fernandez (1982), for example, makes an insightful distinction between cultural and social consensus in ritual practice, where "cultural" in his use refers to systems of thought, and "social" to systems of power relations. In this view, so long as a given ritual serves to maintain some particular social organization, what matters especially is the performative involvement of the faithful, not their faith itself. One's "beliefs," after all, whether in explicitly religious or political doctrine, are ultimately inscrutable, and the meanings of a particular doctrine notoriously difficult to fix. On the other hand, ritual practice can itself be messy, if not inscrutable, producing disagreement about the nature of power relations. A ritual performance may allow for multiple modes of participation, and parties to the same 
practices may derive a range of implications for informal action outside the ritual. In this sense, I think, beliefs actually do matter. Ritual cannot fully constrain ideology and, put into practice, may risk enabling sociocultural subjectivities not envisioned in the preexisting semantics of its constituent symbols. A single ritual performance may in this way resonate differently for differentially situated participants, crystallizing alternative — even opposed — moral paradigms.

It is this textured notion of ritual that I employ, following Kertzer (1988), toward an analysis of ambiguity in the political rites and dominant symbols of the state in late socialist Cuba. As Kertzer amply demonstrates, the political is already symbolic. That is, it is part and parcel of a semiotic system that cannot be reduced to a universal notion of rational action. "Rational actors" in the abstract do not exist. What exists are the subjective objects of social inquiry, which are people who act through any of various paradigms of rationality they themselves coproduce and transform, ritual being one technique by which they do so. Analyzing political ritual in this vein is an effective means by which social scientists can access not only ambiguously shared meanings, but recover contested ones, and so trace the sublimated effects of political struggle.

During my time in the field, I attended no less than a dozen official public events of varying importance. They bore close resemblances in their structure; and in their discursive content they drew on common themes: anti-imperialism, anti-Americanism, nationalist ardor, unified strength in the face of collective hardship, and unconditional support for the Revolution's heroes and leaders. More often than not, the audience was larger than whatever the acoustic system - if there was one - could handle, making it 
hard to discern precisely what was being said. In any case, participants generally paid scant attention to the semantic content of the ritual discourse, and had trouble later recalling it. They entertained themselves instead with talking, gossiping and socializing. Despite an apparent lack of interest, however, they produced the responses expected of them whenever a speaker initiated the standard chants that punctuated all formal public discourse (e.g., "Socialism or death! Country or death! We shall be victorious!”). Sometimes this routine of largely unintelligible speech, capped by collective chanting, followed by more speakers — or perhaps a children's choir or a choreographed dance in between - followed by more chanting, and so on, would continue for ten or fifteen iterations. From a bird's eye view the scene was, seemingly, tightly controlled. But on the ground, so to speak, there was always ample space for participants to make of the ritual a multiplicity of meanings. In what follows, I explore these meanings, with a special focus on electoral rituals. We shall consider, first, the forms of authoritative discourses that sought to cement state socialist discipline, and, second, ethnographic data which evidence how Cubans differentially operationalized these texts through their embodiment of the ritual experience, explaining in variable ways the distant state to themselves.

\section{Authoritative discourse: Participation, unity and discipline}

Through the state-run media and party-controlled mass organizations, the Cuban Revolution has long maintained a tightly bound, centralized meta-discourse about the nation-state and the role of its citizens. Unity and discipline are core concepts in this discourse, while participation is their close cousin. The good citizen maintains national unity around a set of revolutionary principles by participating as expected in every aspect 
of public life, including socialist work and official celebrations. Discipline is both a requirement for and product of moral action so conceived. One must be disciplined and therefore willing to make "sacrifices," to deny the self — in order to build socialism. Properly participating in the life of the socialist state, in turn, produces disciplined men and women guided by a socialist conscience, who only then may fully appreciate the fruits of their struggle. This vision of the New Man, as we saw in Chapter 2, finds its historical roots in the thought and life experiences of Fidel Castro and Ernesto "Che" Guevara, the former heavily influenced by Jesuit teachings and the latter through his work as a physician, fascinated with immune disorders as struggles of the self (Dalton 1993: 19-29). These ideas quickly gained the status of dogma as the Revolution was institutionalized, becoming elements of an authoritative discourse that stands for itself, a fact reflected clearly in Castro's mantra, “everything within the Revolution.” Here I analyze how this discourse still circulates in the stories the distant state tells about its own ritual practices.

For reasons that will become self-evident, Cuban elections are a good place to focus this analysis. The time of my fieldwork coincided with the regular election of the Cuban National Assembly, a ritualized process by which the Revolution affirms its hegemony every five years. The election cycle of 2007-2008 was more interesting than recent ones in that Fidel Castro had already for more than a year been convalescing from a severe intestinal illness. For the first time in some five decades, a figure who was larger than life was now largely out of public life. When the election process began in local neighborhoods, it was not yet known whether Fidel, who had then only provisionally 
handed over the reins of government to his younger brother, would retain his titular role as head of state or even reemerge, fully recovered, into the national spotlight.

Speculation about what would happen and what it would mean was not an infrequent topic of conversation, but with a curious air of detachment: Whether or not Fidel remained president and comandante, everyone agreed that so long as he was alive little change would come to Cuba's state socialist system. Until then, they believed, el comandante would still have the final say on major matters of governance. In this sense, Cubans were less moved by the affair than one might have guessed from the international press coverage (see Stewart 2008). Still, the drama of the moment lingered up through Castro's surprise announcement, in February of 2008, that he would not stand as a candidate for president once the new parliament met to elect the thirty-member Council of State, the government's supreme executive body.

In the lead-up to this announcement, party officials in the local Committees for the Defense of the Revolution organized block meetings to nominate candidates for the national, provincial and municipal assemblies. Beginning in the fall of 2007, these meetings were precursors to the upcoming Jan. 20 general election. The ballots to be produced in voting districts across the island would include a carefully vetted slate of nominees selected at the CDR level, plus candidates from official workers unions and other mass organizations - all of them Communist Party members in good standing and always as many nominees as there were posts to be filled. With the exception of certain celebrity parliament members and central party leaders, including the Castro brothers themselves, those nominated in this process are largely unknown to ordinary people, and 
their personal accomplishments rather inconsequential, except in the most abstract way: they were known to be noteworthy. The state press, meanwhile, published almost daily exultations of the electoral system as supremely democratic and socialist, a testament to the "unity and strength" of the Cuban people, in contrast to the divisive partisan politics of the United States, regularly ridiculed as so much hot air ending invariably in the maintenance of an imperialistic agenda. Anti-American cartoons in the state newspapers typically depict Republicans and Democrats as top-hatted aristocrats yelling gibberish at each other. (This particular Cuban election was taking place at the time of the U.S. primary campaign between Hillary Rodham Clinton and Barack Obama.)

It is important, in analyzing the significance of this practice of political ritual, not to conflate Cuban "democracy" with democracy as construed in Western liberal philosophy. These uses are of course historically related and index similar ideals, but to assess Cuban democracy in precisely the terms and categories of the liberal democratic tradition would fail to elucidate state socialist thinking on the one hand, while also failing to effectively complicate capitalist state systems on the other. As I have argued elsewhere (Armengol 2010), a systematic cultural comparison demonstrates how these ideologies in action might be understood as transformations of one another, one appearing in practice as a game and the other, in turn, as ritual (cf. Damon 2003; Lévi-Strauss 1966). Both forms of democracy rely on public participation in the production of state power, but they operate on contrasting ideological principles. As such, each in its own way warrants a cultural interpretation. My objective here is to produce a fuller understanding of ritualized Cuban electoral praxis on its own terms. 
The Revolutionary constitution of 1976 provides the textual basis for the Cuban electoral process. As discussed in the introduction to this work, Cuba's constitution explicitly constructs a system of governance and an ideological precept by which that system is supposed to work. Situated within this logic, the document outlines a nominally republican and parliamentary form of government, with legislative authority vested in the National Assembly of the People's Power, and executive power concentrated in the Council of State, which is selected from within the parliament. There are apparent contradictions, however. The constitution asserts from the outset the preeminence of the Communist Party of Cuba. It identifies the party as "the superior managing force of society and of the State." State power is thus subordinated to the party and by implication its governing Politburo. But the workings of the Politburo and party politics do not figure at all in the document itself — these are extra-constitutional.

As I have suggested, the logic of state socialism shares with capitalist liberal democracy certain assumptions about human behavior, with the crucial difference being that it explicitly tries to overcome the "material difficulties" of individualism in order to "bring about communism," thereby reproducing capitalism's methodological and cultural assumptions in the first place. The paradigm of a government like the one outlined in the Cuban Constitution, then, is that those putatively individual interests which are the basis of a democracy must be guided by extra-legal principles — and these cannot adequately be codified, else they are subject to change. The party stands then as that supreme source of political power outside of government, capable of effectively resisting the potential for ideological rupture otherwise "inherent" in any democratic system. 
Perhaps surprisingly, however, an entire chapter of the constitution (Chapter XIV) is dedicated to the electoral process. It reads much like one would expect of the electoral process in a liberal democracy. Representatives at the local and national level are chosen by universal suffrage, with only minors, convicts and the "mentally incapacitated," restricted from voting and candidacy. The number of seats allotted to a legislative district must match, proportionally, the number of people residing in it, so that the principle of "one person, one vote" is not violated. And delegates elected by "free, direct and secret" ballot must receive a simple majority of valid votes cast in their respective districts. One way to view the situation in light of the actual electoral process and outcome, as many critics suggest, is that this system is a grand lie, a political sham. In practice, it is true, the entire process is subordinated to party control — this much already is envisioned in the constitution. But analytically, it is more useful to understand the election as a socialist ritual that in spite of itself reintroduces a liberal notion of the possessive individual whose interests must be balanced and checked by those of others. The distant state spends a great amount of discursive energy on ensuring the successful performance of this ritual, with its outcome preordained, even while it promotes the ideals of individual equality and liberty.

Ordinary Cubans, like citizens of other modern states, are not especially aware of what their constitution actually says (despite the copies periodically published on newsprint and distributed at postal kiosks in the cities); but, again, this is beside the point. The point is that the constitution is a key symbolic text crystallizing a particular cultural 
configuration, the categories and concerns of which are refracted in other more popular if no less significant texts.

Fidel is the chief authorial figure of such texts. In the weeks and months before the general election, Granma reprinted on its front page excerpts of speeches he delivered in previous election seasons, in early 1993 and late 1997, alongside photographs of a more vigorous comandante wearing his trademark olive-green uniform. These appeared under the banner "UNITED VOTE," with a typical headline reading, "The most important thing is participation," or simply, "A revolutionary strategy" (Figure 4.1). What these texts emphasized was not competitiveness in the electoral process (how could they?) but a struggle against, in effect, familial strife. The goal, in the supreme leader's words, was to achieve the greatest possible level of electoral participation and, within that, to maximize the number of "united" ballots, that is, ballots indicating the voters' approval of all the candidates listed. The converse was also emphasized: Fidel urged his compatriots not to cast null ballots. Many Cubans I knew claimed to do just this, even though published results always cited nullifications in the single-digit percentages. (This figure, in fact, had been steadily dropping since a high of about 7 percent announced in 1993, at the apex of the post-Soviet crisis.) Discursively, Fidel's entreaties employed an impersonal imperative verb form available in Spanish that does not easily translate. Using this form locates a command outside of the speaker as its agent and the necessity to comply with it beyond the addressee alone as personal recipient. These were things "that must be done." All of us (i.e., good Cubans) were by implication bound: 


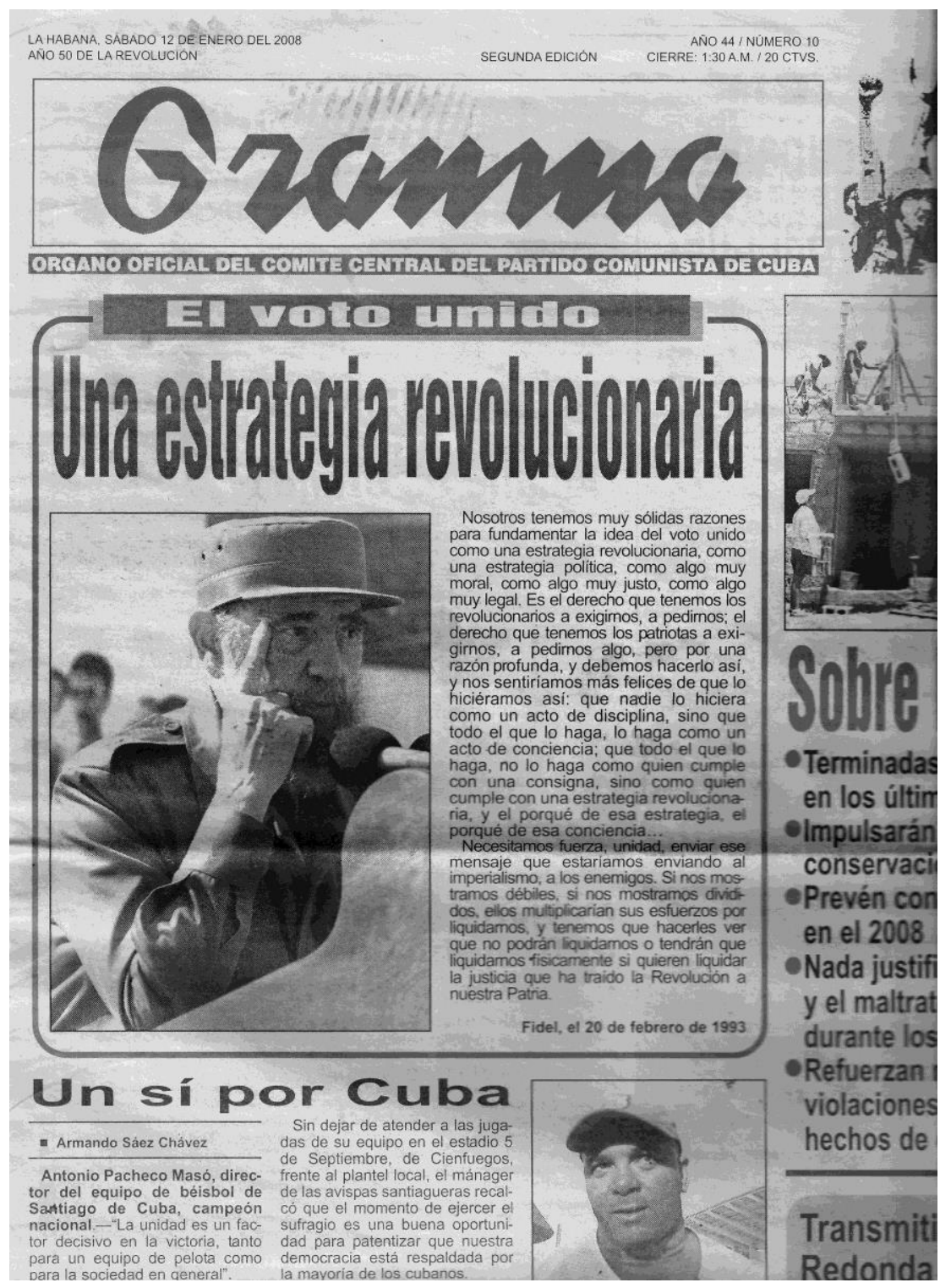

FIGURE 4.1

"The United Vote: A revolutionary strategy" 
... to work intensely so that the number of votes left blank are fewer, so that the number of votes nullified by strikethroughs, or whatever the case may be, or by slogans, be they against or in favor of the Revolution, because there are some who do so in an excess of enthusiasm, are minimized; and it must be that the united vote attain the highest possible number of votes cast for the Revolution and the Fatherland. (Castro 2008c [1997])

A further implication is made here, of course: that among the few nullified ballots, a significant number may result not from counter-Revolutionary sentiment or even neutrality, but from overflowing enthusiasm. The good Cuban voter is also a disciplined Cuban voter, and one best expresses love of country through that discipline.

A different excerpt, from a 1993 speech, was reprinted in Granma twice, in identical form, a mere two days apart, placed next to the same photograph of Castro and in precisely the same location on the front page, under only a slightly different headline all this demonstrating the repetitive and self-referential nature of such discourse. In this case, Fidel explains that while voting per se is a "technical" exercise of one's rights, and that voters can easily be taught how to cast votes "for one, for two, for all or for none," casting a united vote is, however, a political act and a strategy of "patriots" and "revolutionaries" (Castro 2008a, 2008b [1993]). This practice of strategy is contrasted in the text with the invocation of a mere "slogan," even though in practical terms its constant repetition in the media makes it by definition a slogan of the distant state. And so is this authoritative discourse, by circular reference, always striving to vitalize and naturalize itself, paradoxically declaring to be (and so construing) that which ought not require a declaration because it already is. 
On a few occasions, el comandante personally penned missives about the ongoing election to his countrymen, signing them as with his "Reflections," noting the date and time of their filing to the minute the night before they appeared in the paper. He did just this the very day of the general election, addressing his "comrades of western Cuba," where "cold winds blowing from the north, accompanied by showers and rain [...] mean to conspire against our elections" (Castro 2008d). In this way, Fidel announced that he had cast his own united vote, calling it an act of "conscience." A northern cold front had indeed arrived in Havana and the neighboring provinces, but the allusion was not incidental. It was meant to suggest yet another attempt by the United States to meddle in Cuban affairs, playfully indicting the power of "the Empire" to manipulate nature herself, such was the yanqui menace.

Other celebrities and prominent Cubans fill out the echo chamber of the electoral script. In 2007-2008, Granma often ran brief interviews with baseball greats, telenovela actors, distinguished artists and scientists, and (in one case) the wife of one of the Cuban Five imprisoned in the United States on espionage convictions. These testimonials portray voting as a "moral duty," necessary to defending socialism and the Revolution; they compare it to playing together on a single team, struggling for victory; and they declare the personal intention of the speaker to cast a united vote. In a joint public letter from key political leaders, including the central head of the CDRs and the president of the national student union, the authors sign off in a discursive chorus that any Cuban could recite in his sleep: “Thus also spoke our national hero, José Martí, when he affirmed that 
'together much can be accomplished,' and so together we shall vote for all, which means voting for Country, for the Revolution, for our Socialism.”

Actual news coverage of the election campaign, if one can call it that, was no less repetitive than the overtly ideological proclamations of Fidel and his symbolic proxies, often dwelling on the technocratic preparations for the coming election day or recalling with admiration the strong turnout in previous ones. One such story features Cuba's justice minister and chief of the electoral commission, who describes a new ballot that offers electors the "comfort" of voting for all the candidates simply by marking an X in a large circle at the top of the sheet, without further effort. From time to time, Granma would publish sample ballots showing, with an arrow, precisely how to cast a united vote; similar sample ballots also appeared in divisa-store windows (Figure 4.2).

Another story praises the "all-star" cast on the party's official slate of candidates, selected through nominating meetings from among some 55,000 "pre-candidates." The author extolls their merits, including prior service as municipal delegates, and honorable employment as teachers, scientists, factory workers, etc., from a variety of backgrounds, ages and ethnicities, representing "the distinctive traits of present-day Cuban society" (Mayoral 2008). Not one is mentioned by name in this short piece, though prospective electors are invited to examine the biographies of nominees posted in cities and towns "in numerous places" and to meet with candidates at "popular gatherings," none of which anyone seemed ever to attend. While it's true that candidate posters were a common sight, if not meet-and-greet functions, often the bios were taped to the windows of state shops and largely ignored, becoming yet another authoritative symbol in the background 


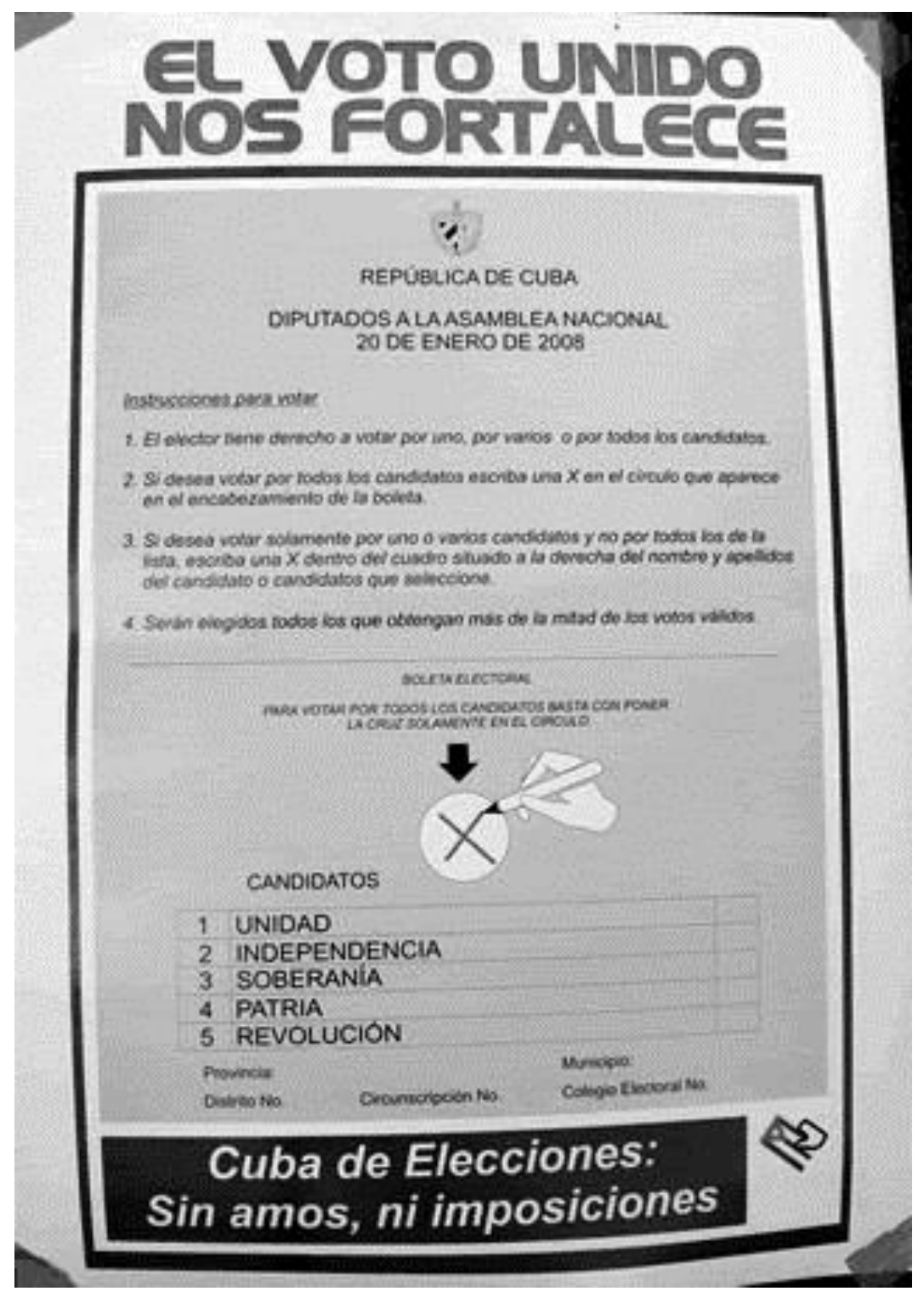

\section{FIGURE 4.2}

"The United Vote Makes Us Strong." Sample ballots such as this one advise Cuban citizens on how to cast a vote "for all." 
of everyday life. At CDR meetings, these biographies were read aloud in monotone before or after participants discussed more prosaic neighborhood matters, such as adequate trash collection or mosquito control.

Below this Granma article, a chart provided readers with figures on the last three election cycles, showing in each one an uptick in participation, but also an uptick in the number of "selective votes," that is, valid ballots that did not reflect a "united vote." By 2003, selectivity totaled just under 9 percent of votes counted. During the 2008 election, this figure would rise again, to a little more than 9 percent. While these differences may seem insignificantly small in the liberal democratic tradition, many Cubans told me they read such news closely for its symbolic content: Such figures suggested, however minimally, the degree to which the party wished to publicly acknowledge fractures in its political hegemony. Indeed, this is generally how master texts such as Granma were read, when they weren't being used, quite literally and because of a perennial shortage, for toilet paper. The fact that the content of the texts was so repetitive did not mean it was ignored; rather, it was the slight variations in the repetitiveness or the "meaning between the lines" to which readers were supremely sensitive.

Other news on TV and in the papers covered what was called "intensification" of the electoral machinery, noting seminars for poll workers in advance of Jan. 20; the testing and certification of polling procedures; and the rules for submitting absentee ballots or voting, if necessary, outside of one's home district. Granma announced electoral success in banner headlines the first day after the voting ("More than 8 million Cubans voted") and on the second day ("The united vote triumphed!"), recapitulating two of the ritual's 
central tropes - participation and unity. Thus were Cubans ritually individuated into equal citizens so they may be reconstituted as common subjects of the socialist state.

\section{Variable performance: Moral indiscipline and obedient indifference}

As I have repeatedly suggested, the elaboration of socialism on the scale of the nation-state in the twentieth century did not produce as radical a break from the modernist capitalist project as is sometimes assumed. If anything, as this election rhetoric suggests, Cuban citizens are envisioned as hypermodern subjects, individuated in the service of a larger mystical power. "Modernity" and the modern state, as Foucault (2006 [1991]) argues, is predicated on the production of atomized persons through and for the mechanisms of governmentality, by which he means the implementation of a rationalistic political-economic logic over a certain population with the aid of "apparatuses of security." This praxis is not particular to states or inherent in their nature but rather developed within already existing forms of state administration in the post-Enlightenment era; at the same time, Foucault shows, it has seeped into nearly every aspect of life: the family household, global transport, economic enterprise, the educational sphere, to name a few. We have seen that far from excising governmentality, the Revolution in Cuba has ratcheted up the practices of governmentality toward the production of social wealth planned, centralized and subject to rationalistic redistribution.

Modernist productivity, capable of reaching levels never possible in feudal or archaic societies, requires ever more precise techniques for disciplining modern subjects. This is why Foucault's work on a whole was concerned with "the different modes by which, in our culture, humans are made subjects," including exams, prisons, hospitals, registries, 
queues and the like. It should be no surprise then that the idea and practice of "discipline" is equally important in the modernist socialist context as well. Furthermore, whereas the disciplining of modern capitalist subjects now takes place inconspicuously, i.e., largely without reference to its own existence, in socialist Cuba it has always been a salient theme in the ritualized discourse of normal citizenship: The notion of discipline itself is a disciplinary technique.

In the same way, discipline is regularly explained by appeal to its shape-shifting opposite - indisciplina social. References to "social indiscipline" figure heavily in the authoritative discourse and warrant a brief elaboration. It is "every incorrect thing, everything done badly, every immoral thing," and all people involved in such forms of indiscipline "are torchbearers of the enemy, they are conscious and unconscious agents of the enemy," they are ominously likened to ships nearing the shoreline "to invade our land" (Castro 1988). And it is suggested that the undisciplined are those who have become enchanted by the capitalist world of consumption, who do not value work but skirt it at every turn, who seek to emigrate from Cuba by any means, legitimate and otherwise (Castro 1999). They are said to be guilty of la doble moral: literally, a "doublemorality" or duplicitous character.

Whenever it takes on specific content, indiscipline conflates a whole range of putatively harmful social action. It equates domestic violence, "youth delinquency" and common criminality, as well as terrorist acts against $\mathrm{Cuba}$, brawls at national baseball games (see Barros 2008), even littering on the island's renown beaches (see Peláez 2012), with — crucially — what most Cubans would consider common forms of 


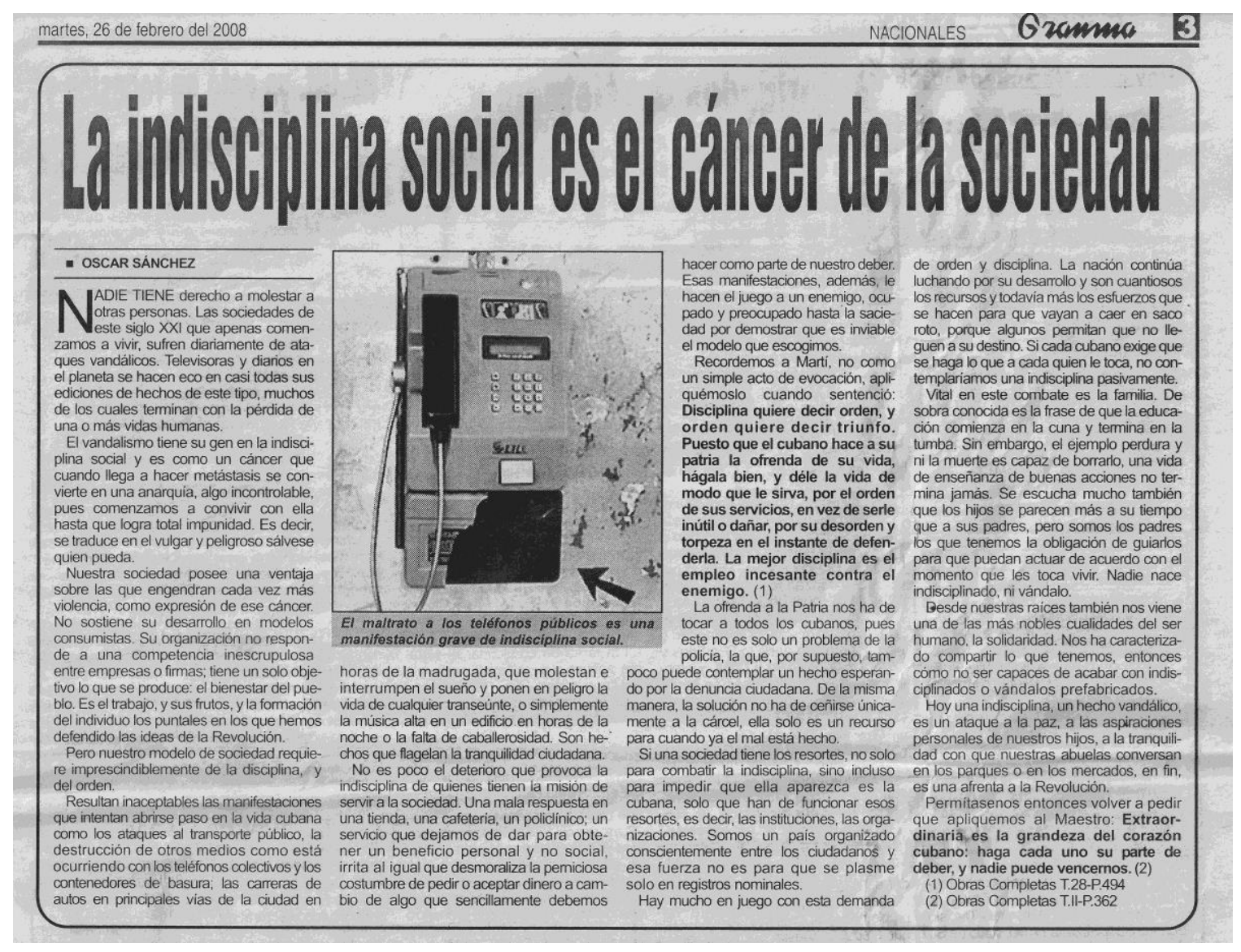

\section{FIGURE 4.3}

"Social indiscipline is the cancer of society" 
inventiveness, thereby putting the distant state rhetorically at odds with those behaviors that people feel are necessary, ordinary and in their own way "socialist."

The rhetorical deployment of indiscipline and la doble moral entered full swing in the state press and on television shortly after Raúl Castro was sworn in as president, coinciding with a number of high-level sweeps of agros, including Cuatro Caminos and other areas of the city known for legal and illegal cuentapropista activity. They also coincided with the widely publicized arrests of alleged agents of the "Miami mafia" operating in Cuba, shown on secret videos discussing terrorist activities. In a typical column, printed alongside the picture of a vandalized public phone, the author equates all manner of social ills (including rude attendants at state health clinics and cafes) with such acts as using one's position to seek "personal gain" over and above providing adequate service or, similarly, "accepting money for things that we should simply do as part of our duty" (Sánchez 2008). A bold headline above this story declares social indiscipline to be "the cancer of society" (Figure 4.3).

Such allusions to invento, my informants asserted, were meant in large part to demonstrate the continuity of official rhetoric in the transition of leadership from one Castro brother to the next. "We've heard this all before," they would say. And however moral they felt the morality of invention to be, they were well aware that a hegemonic, centralized and authoritative view of things stood ready to call into question their competitive solidarity and, unexpectedly and intermittently, clamp down on it, creating a persistent sense of moral ambivalence (as we saw earlier with Dante's statement) if not confusion. For example, in the late 1990s, Fidel himself made many allusions to the 
invento market in his public attacks on "social indiscipline," at the same time as invento practices were expanding in numerous ways. In one speech, before the Youth Communist Union (Unión de Jóvenes Comunistas, or UJC), Fidel railed against the burgeoning "undisciplined migration" to the capital city by residents of the other provinces, saying such acts amounted to a betrayal of the national trust (Castro 1997); but many of those who came were lured by work opportunities in new agros and other forms of selfemployment, often coming at the behest of family and friends who had inventive projects to offer them.

In the same speech, el comandante bemoaned the "lack of discipline" in a hardcurrency sphere the government itself had created. It was by then standard procedure for private innkeepers to work closely with each other in meeting the demand created by the upsurge in tourism. If a foreign client needed a room, and a landlord's own house was filled, she would invariably find backup locations among her competitors, often unlicensed friends, each helping the other, and in the process building dense networks of reciprocity. While traveling across the island in 2003 and again in 2005, I learned quickly that a visitor was never turned down over the phone; if you called a casa particular (literally, a "private home," that is, one with a room for rent), the proprietor always told you to show up, even if she herself had no available beds. In that case, she could always find a room in another casa particular, licensed or otherwise, with a monetary commission or exchange of favors having been worked out on the side. If this was "indiscipline," it was morally necessary. But the supreme leader firmly rebuked such practices, however indirectly. For example, Fidel would say national security was put in 
grave danger whenever Cubans hosted foreigners without providing the authorities with identifying information on their guests, as licensed renters were expected to do on sworn declarations: "The sworn declaration will have to be taken seriously," Fidel told his UJC comrades, "because the country has no other alternative but to struggle [luchar] against that type of indiscipline, which causes harm in every sense" (Castro 1997).

We have seen that key state symbols — as propagated in election discourse, news reports and Castro's speeches, themselves an almost nightly TV ritual for decades — are those of unity, participation and discipline. Now we see that this discourse also provides an unmistakable and problematic meta-commentary on the morality of invention. Cubans are instructed at every turn that, to be proper revolutionary subjects, they must cast a united vote, participate fully in rallies and other ritual functions, and at the same time exercise their individual autonomy: not however in "improper" ways. Disciplining national subjects in this way was, in any case, the intent of the distant state. But these "improper" activities were coterminous with much of what Cubans did to get by in their everyday lives, and so this discourse equated their livelihoods with nothing less than conspiring with the enemy. Already I have noted several ways in which Cubans reimagined these intentions in alternative ways. Indeed, the authoritative discourse of state ritual cannot fully be understood if we do not correlate it with the lived reality of its symbolic content.

With this in mind, let us return to the 2007-2008 national elections. I asked many of my informants what they thought of the democracy rhetoric and how they approached voting. The answers varied in a discernible pattern. Simplifying the situation for the 
purpose of analysis, we might identify three broad groups. In the first case, the more alienated and disaffected a person felt, the more one saw electoral politics, and state ritual more generally, as a farce. In the second case, for those whose livelihood was tied into the party machine, elections and other state rituals represented a genuine expression of the people's will. These first two shared, interestingly, a similar understanding of the rhetoric in that they took the content of it at face value and evaluated it as such. In both cases, they tended to be better-off financially, with regular access to hard currency; they were more likely to identify themselves, racially, as white; more of them had some higher education; and they were overall, I believe, in the minority among Cubans.

On the other hand, the more embedded one's relations were in the invento market, whether or not one was self-employed in the technical sense, the more one tended to view state ritual in an instrumental and performative light. This is the third broad social grouping, one that I have tended to gloss, somewhat simplistically, as "ordinary Cubans." While there is in practice a fair amount of demographic overlap and similarities among all of these groups (I would hesitate therefore to refer to them as "class" divisions), this last population is in my anecdotal experience the most numerous in Havana, and for the purpose of my analysis the most relevant. In what follows, I draw out my reasons for this claim, by comparing their perspective with that of the "fully disaffected."

Those most detached from the system, as I noted above, were critical of it in a manner that took the distant state's rhetorical content at face value. Like outside critics operating within a standard, universalistic set of ideals inherited from Western political science, they felt that the central feature of Cuban elections was that they were rigged. "In the end, 
it's always fixed," as one man put it. This was a barber named Joaquín who worked on the left making house calls for his clients, but did not make most of his income from this activity. He and his wife, Yolanda, had two grown children overseas who worked in professional fields and supported them with remittances, and a third who was mentally disabled and received some institutional support. Joaquín had traveled outside of Cuba to visit his son and daughter, and Yolanda was planning such a trip.

She was having coffee with us during our conversation about the elections and, right on the heels of her husband's declaration, she recalled how a local CDR representative, or cederista, visited their house one election day years ago. The cederista knew their daughter-in-law was leaving soon to visit her husband, who had left the country ahead of her to establish himself in his new life. If you want her to make the trip, Yolanda remembered the cederista saying bluntly, you had better go vote today. So Yolanda went to vote — "what else could I do?" she said — but scratched out her ballot . "It doesn't make any difference," Yolanda insisted, echoing her husband's view. "The statistics they release are all made up anyway."

Such views were common among this disaffected subset, generally those who had access to dollars and felt the Revolution had thwarted their life opportunities. Although they said the electoral process was rigged, for the most part they voted in any case and claimed (though of course there is no way to verify this) that they nullified their ballots. One acquaintance who for years had been waiting patiently for his name to come up in the U.S. visa lottery (known throughout Cuba as el bombo) told me he got out of voting by telling the CDR people in the neighborhood of his mother's home that he voted across 
town, where his father lived. Then he told the cederistas in his father's neighborhood that he voted in the zone where his mother lived. And so party operatives in both places left him alone.

Even in this group, however, most did not identify as "dissident" any more than my cuentapropista friends who lived mainly off peso incomes. In fact, like most Cubans they shied away from the term partly out of fear but mainly out of a sense of ennui in the face of the distant state's political hegemony. Rather than would-be dissidents, they represent what Weinreb (2009) has termed "dissatisfied citizen-consumers" many of whom suffer from a kind of internal exile, both physical and psychological.

They might say, for example, that you could nominate a person who was openly opposed to the system at a local CDR meeting. Sometimes this really happened: you could do it, my friends told me — but there was no point. Often known dissidents were felt to be strident, unhelpful personalities. They were people who did not engage much in the reciprocal relations expected of them, people no one on the block liked much in any case. (Dissidents themselves tend to say the system is so corrupt it would be a mistake to participate in its structures, even in an oppositional manner.) So "ordinary" and "deeply disaffected" Cubans alike regarded such people not unlike they regarded the party faithful or high-ranking party leaders. In their view, both were blind, both equally out of touch with everyday life, and of suspect moral character: How exactly did they make a living anyway? Yolanda told me that during a nominating meeting in a nearby district one resident put forward a known dissident for consideration — and all of four people voted for this nominee. Votes at such meetings are not taken in private, unlike in the general 
election. They are conducted by acclamation or, if necessary, a show of hands. There might have been other residents tempted to support the alternate candidate, out of sheer bitterness over the crisis of the Special Period or out of distaste for party politics. But a basic calculus stood in their way: Why risk sticking my neck out for that crank?

For those who took the election rhetoric less seriously — again, most habaneros I knew through their work in the invento market — the perspective on such mass rituals was somewhat (though not entirely) different. Ignacio, the bike mechanic who worked at Abel's shop near Cuatro Caminos, provides a representative case in point. In late January of 2008, the week after the general election, I asked him if he had voted. He began with exactly the utterance that other self-employed Cubans often used in reply to this question: “Por supuesto." Meaning, “Of course," or more literally, "that's a given.” I asked him to explain and he went on:

Why risk hurting yourself? You have to keep your options open. Right now, I make about six hundred pesos a month renting this space to Abel and working for him. On any given day, the state might come here and, even though we've kept the inspectors happy, they'll say, "Enough is enough. You've got to shut this thing down." And then I've got to have a backup plan. Maybe I go to work for the state full-time again if something good turns up. You have to keep your options open, so you've got to keep a clean record. The best jobs will always require "verification." That means they check your social record, well, unless you know someone in a superior administrative capacity who can help you get around that process. And that process involves sending people to your neighborhood, like for example, to ask the CDR chief if you vote, if you participate in volunteer work, and so on. If they don't like you or have it in for you for some reason, that could ruin your job prospects. You would never know for sure, because when you're denied the job they 
don't tell you why — "You didn't meet our criteria," maybe that's what they say — but, you would still basically know what they meant.

When informants in Ignacio's cuentapropista cohort made this sort of argument, it's important to note, they did so differently from those I have described as the more deeply disaffected. That is to say, they did not say such things in a critical light, but rather offered them as they would an obvious fact of their everyday lives. A self-employed photographer once quoted an old saying to me to explain why he voted but also, in a larger sense, to explain how he relates to the state: "You have to be gentle as a dove and clever as a snake." In the interview with Ignacio excerpted above we can see clearly how the state is experienced in both its distant and intimate forms, and how these are interrelated. In the first instance, "the state" is an impersonal thing that acts, on occasion, capriciously: through the actions of nameless, unrelated others who lack a proper sense of competitive solidarity with the rest of us. This capriciousness can at times be mitigated through intimate connections one has built with low-level, friendly agents of the state. At the same time, one should pay it due respect. You vote to keep your options open. If you keep your options open, you might land a state job when you need it. And, as we have seen, what one generally does with state work is to repurpose it, to the extent possible, for the morality of invention.

The automatic response to questions such as "Did you vote?" or "Did you go to the rally?" was so routinized as to have become a parody of itself, if you will: a kind of quotidian counter-ritual. I witnessed this on my way home from Havana's May Day parade in 2007, the first year Fidel Castro was absent from the festivities. International 
Workers' Day is among the most important state holidays of the year. The parade in the capital is the biggest of those held in the major cities across the island, culminating in an enormous rally and notoriously long speeches at Revolution Square. Evening was fast approaching after a long day of marching when I found myself walking down a residential street with Lourdes, the self-employed innkeeper whom we met in the last chapter. We came across each other and had stopped to exchange pleasantries when we also encountered another person known to both of us. He was a friend of hers, one of the many business associates who helped her with her rental.

He said hello and intoned in an imposing voice, "And why were you not at the square today? You were not seen.”

It was true, I knew, Lourdes had not been to the rally. But she replied instantly, deadpan: "We were of course there! In fact we arrived at six in the morning and we're just getting back now." When they both saw the quizzical look on my face, they broke out in laughter and I realized another joke had been made at the anthropologist's expense. Not long thereafter, I fell prey to a similar routine, this time at the hands of a fairly successful independent film producer, Nicolás, who lived in my neighborhood. He owned a car, dressed smartly, and boasted of having business contracts with state media agencies as well as entrepreneurial artists. While we chatted at a neighborhood birthday party, I shared some of my thoughts on the recent rally, and I asked if he had marched. "Of course I was there," he said. "I was with Industrial Unit 527!" I had no idea what this meant and gave him, no doubt, the usual odd look. "Listen," he explained. "Everybody 
says that. I haven't been to a parade in the last thirty-six years. It seems to me the most subtle — the plainest — the loveliest way — to waste time."

That's funny, I replied, and told Nicolás about the encounter I had had with Lourdes and her associate. When people respond to questions like that one, he told me, it's always the same: Usually you're joking, assuming you're close with the person you're talking to. The very question, in fact, is meant as an opening to satirical play. But you reply, "Of course," in a serious voice, to everyone, just in case. With the rallies, it's easier not to attend, but to act as though you did, than it is with voting, because in elections one's participation is recorded, person by person. Some supervisors at state firms didn't care much about rallies or the election. But at other workplaces, especially in top industrial sectors like tourism and biomedical research, there was pressure exerted on staff members to attend political functions as a group, lest one risk forfeiting a divisa bonus due at the end of the year, or lose out on a foreign post if the chance arises. By my own count, tens of thousands attended the May Day parade that year, but practically everyone said the crowds had noticeably diminished as compared with times past.

The invento perspective on mass state rituals, then, might best be described as a practiced form of obedient indifference. It is obedient because the criteria of participation and unity are met, discursively anyway, almost without fail. But it is indifferent in at least two important ways. First, as to its manner of practice, which we have seen is highly variable and often performed as satire. Second, indifference is felt toward the symbolic content itself, which is reframed in the subaltern political struggle of invento. 


\section{The ritual production of moral dissonance}

The full measure of the "obedient indifference" I have just described was on display on a warm night in September 2007, at a nominating meeting in a voting district not far from where I lived. Lourdes knew of my interest in such things and invited me to join her. We met just after dusk and gathered with a crowd of about eighty people from her block, under the canopy of a ficus tree, outside the apartment building where the local CDR president lived. It was hard to make out faces in the dim light of a bare bulb dangling in the foyer. Lourdes arrived somewhat concerned because she had not received at her house an official slip of paper that she was expected to bring with her, to document her attendance at the meeting. But we ran into a cederista who had an extra form, and this seemed to set Lourdes at ease. Chuckling as she filled in her personal data on the sheet, she had to ask another friend to remind her what their zone number was.

The meeting began when a middle-aged man announced that the CDR president was sorry he couldn't make it and that he, the vice president, would chair the meeting instead. The man also said he was sorry about the low light. Then he invited attendees to join him in singing the national anthem. He sang the first bar and the crowd followed more or less on cue. After the hymn, a second cederista unfolded a sheet of paper and, getting as close to the light as possible, read aloud an official statement about the importance of elections in Cuba, "as opposed to other elections where money decides who wins." While this was going on, I stood with Lourdes and a few of her neighbors at the outer edges of the meeting, along the sidewalk. Here, people wandered around and chatted with one another about various day-to-day concerns during most of the meeting. Lourdes and her friends, 
for example, were commenting on the new public buses in Havana, recently imported from China, while a group of men argued about the upcoming baseball playoffs in the U.S. Major Leagues. No one around me seemed to be paying much attention to the nomination process, except to respond reflexively with a lively and heartfelt ";Viva!" to the standard prompts, "iViva la Revolución! ;Viva Fidel!"

With the reading of the election statement and these chants finished, the chairman said more prosaically, "Well, here we are, this meeting is to nominate a delegate for the national assembly, to be elected later on the twentieth of January." The nominee so elected was to represent this CDR and several other adjacent ones. A woman I recognized as the cederista who had collected attendance slips at the beginning of the meeting raised her hand at this point and said she wanted to nominate "la compañera Milagros de la Concepción," whom the cederista described, clearly by rote, in this way: "A lieutenant colonel, retired, from the Ministry of the Interior, a faithful public servant who gave more than twenty years of her life defending the Revolution, and furthermore, an upstanding citizen, a revolutionary model who will do an excellent job," and so forth. The description went on for several minutes, but few were paying attention and the chattering increased.

"All right," said the meeting chairman, speeding up the pace of things. "Do I have any other nominations? No. All right, then let's vote on the candidate. All in favor of Milagros, raise their hand." As he was speaking, the persistent chatter in the crowd had continued, but at hearing the word "hand" it stopped abruptly, and hands shot up all around. Glancing quickly about, I noticed there may have been three or four who didn't 
vote, but not much more than that. The chairman started counting hands, got to about fifteen, but then stopped and said, "Well, it looks pretty unanimous, right?"

Just then a new voice, belonging to a woman I didn't recognize, rose above the chatter. "Shouldn't we take a vote to see who says no?"

"Well, there was only one candidate, and almost everyone voted yes," the chairman said. More chattering.

A different woman from the opposite end of the crowd spoke up now, and the chattering paused again momentarily. "This person who was put forward," she said. “This 'Milagros.' She isn't from our neighborhood and none of us even know her. I think we should have another nominee, so that at least we can vote between two people."

"Well, look," the chairman said, addressing the crowd this time in a paternal tone. "We had one nomination, no others were nominated, we voted and we chose that person. This is what the law prescribes. So we're done."

By now, the chattering had risen a notch and people were commenting on this odd exchange. One sighed exasperatingly when the second woman made her complaint, but a few others seemed to support it. One man spoke out saying he was new to this CDR but that in his old CDR they were able to nominate more than one candidate for the general election. But a group of cederistas standing around him said, no, that's never been the case, we've always done it this way. "And anyway," a cederista told him, "this is not an election but a nomination. You'll get a chance to vote for or against this person when you go to the polls for the election.” 
"Is there any other business to take care of?" the chairman interrupted. "Because I can tell there is some restlessness here." Now a third woman came forward to support the complaint of the other two. The chairman became testy: "Would you like to propose yourself for the position?" he said.

"No," she replied.

"Well then." More mumbling and commotion.

The second woman to complain came forward once more. "All right," she said, gesturing toward a friend in her 50 s or 60 s who was standing next to her. "I'd like to nominate our compañera Juanita Contreras.”

"Tell her to come out where we can see her," a man in the crowd said.

Juanita stepped out from the shadows and spoke on her own behalf: "Come on, people. Who doesn't know Juanita Contreras?”

“Ay, Dios mío," Lourdes said under her breath. There was some uneasy laughter now mixed with the chatter.

But the chairman allowed the nomination to proceed, and the friend who had put Juanita forward made a little presentation, much like the cederista who had nominated Milagros, though this one was obviously delivered off the cuff: Juanita is from the neighborhood, she said, she's a good person, she'd represent us well, and so on.

"All right," the chairman said, cutting short this impromptu biography. "We have two proposals, so we should vote again. Now, this vote is for real, people. Raise one hand and vote only once. Who would like to nominate compañera Milagros?” 
Hands shot up again, but nothing like the number that went up the first time. Lourdes and her friends, I noticed, still voted in this group. The chairman counted quickly, moving his index finger clockwise around the crowd of bodies now shuffling back and forth, clearly getting antsy, before arriving at a complete count. "Fifty-eight," he said. $\mathrm{He}$ repeated the same exercise for Juanita. Smiling at Lourdes, I joined this group and raised my hand, "because she's the opposition candidate," I whispered. Other hands went up, and more than a few. The chairman counted and announced the result, "Forty-seven." Milagros had won, again, and this time the vote was final. There were no further complaints. The appointed lector read one more official statement closing the floor for nominations and thanking everyone for participating in the democratic process, fulfilling one of their utmost duties as a revolutionary people. Gradually the crowd dispersed, with everyone still chatting as they shuffled away, back to their homes.

As we were leaving, I asked Lourdes why she voted for Milagros if she didn't even know who she was. "Ay, Robert," Lourdes said, in her usual way. "The thing is to get out of here as quickly as possible."

At first I was surprised with the mix of formality and confusion, control and disorder — what Cubans playfully call relajo (literally, "a relaxation," or a mess of things) — that pervaded this nomination meeting. But when I shared this story with friends at Cuatro Caminos and elsewhere, their response was generally one of yawning. This is how it always is, they said, not exactly the same, to be sure, but variations on the theme. In their view these kinds of messes commonly happened when, to put it in my analytical terms, the distant state's authoritative project was enacted at the level of everyday life. The fact 
of such rituals being messy in practice, they themselves pointed out, did not change their outcome, but it made them more bearable and (for their own purposes) more efficacious. By treating the ritual with a measure of relajo, habaneros were effectively performing a satirical "hidden transcript" (Scott 1985). While the satirical mode however did not challenge the system, it promoted a disposition toward the distant state that cannot properly be described in terms as simple as "for" or "against" the authoritative transcript of the Revolution. These were, rather, dispositions that accepted state ritual as appropriately enacting solidarity, but through a performative content that should not be taken at face value. What mattered, as Lourdes had told me, was first and foremost participating, and, secondarily, getting on with life — the faster the better. These rituals reified the hegemony of the socialist state but also unhinged the official meanings of the key terms embedded in them, such as "la lucha," socialism and revolution itself, making possible what I have called the people's socialism.

But what should we make of the oppositional moment? That is, how should we read the disruption effected in the nominating meeting I have just described, when a few people rose to complain that the first round of voting was uncontested? There was a fair amount of disagreement on this issue. Some, mostly those who did not know the complainers personally, thought they were troublemakers who didn't "get" the performative essence of the meeting. Others thought they were good people, "not counter-revolutionaries or anything like that" — well-meaning neighbors who simply wanted more of a say in the electoral process. There was general agreement, however, on one point. When I asked people if these women who disrupted the expected course of the 
meeting were "dissidents," they all said, with certainty, no. These were party types, they told me. The more cynical said they were part of a faction that didn't care for the local leadership, and here was a way of showing it. This was low-level, internal party politics, in their view. Bound by a discourse of equality and fairness, the acting chairman (though he was annoyed) allowed the revote to take place.

You see, Lourdes told me, these party fanatics can be a real nuisance. Habaneros like Lourdes who were meticulously interconnected in the invento market saw such people as mainly out for themselves. Paradoxically, those who took most earnestly the electoral rhetoric about individual choice resolving itself in "unity" were the most likely to be perceived as self-centered and power-hungry. But these same people, one couldn't forget, might serve an expedient instrumental purpose in the profane course of life. This was especially true for Lourdes, as they helped her remain in good standing with the housing officials who oversaw her business. "Oh, yes," she said, turning serious for a moment. "It's very important, very important, for me to go to those meetings. It helps me, do you understand?"

Invento entrepreneurs such as Lourdes did not generally see state rituals, as in the case of elections, as an affront to their "individual freedom." Nor did they view them in an entirely cynical light as "fake democracy." Rather, these practices were appraised on the basis of their performative efficacy, and in terms of the morality of competitive solidarity. The best kind of local leaders were those who hurried through the exercise and supported, in their everyday lives, the people's socialism. The rituals that lent themselves to such ends, while they may be regarded as a hassle, were felt at least to be useful. It 
made sense then for someone in Lourdes's position to speak seriously in one breath of the importance of voting and in the next breath ridicule the May Day march, as the latter had little connection with her proximate social network. The morality of invention — not the "tempting," "natural" and individualist morality of the enemy, as imagined in the authoritative discourse — provided the ethical lens through which most people evaluated the distant state's disciplinary efforts and poked fun at them.

I found this perspective to be widespread. One didn't have to be directly tied into the invento market, which in any case was at the periphery if not the center of nearly all productive social interaction. For example, I asked Marco, a rather straight-laced government researcher from my neighborhood, what he thought of the May Day parades. Like the independent film producer, he said they were a waste of time — and, for that matter, of public money. "Can you imagine the costs incurred?" he said. "All those trucks and buses to bring workers from the provinces to the city — when there's such a shortage of gasoline to begin with." He compared this "absurdity" as he called it, to all the official efforts made to whip up support, in the form of huge crowds and rallies held seemingly every day for months, in support of the return of Elián González, a shipwrecked boy who only a few years earlier had been the subject of an international custody dispute (for an insightful, and amusing, cultural analysis of the affair, see Sahlins 2004: 166-193).

"Think of all the kids who go without milk after the age of seven because it's not provided on the libreta," Marco said. He made it a point to say that he agreed, legally and ethically, with the Cuban government's case (as did most Americans, incidentally), but he resented, along with many Cubans I knew, the application of so much ritual energy, 


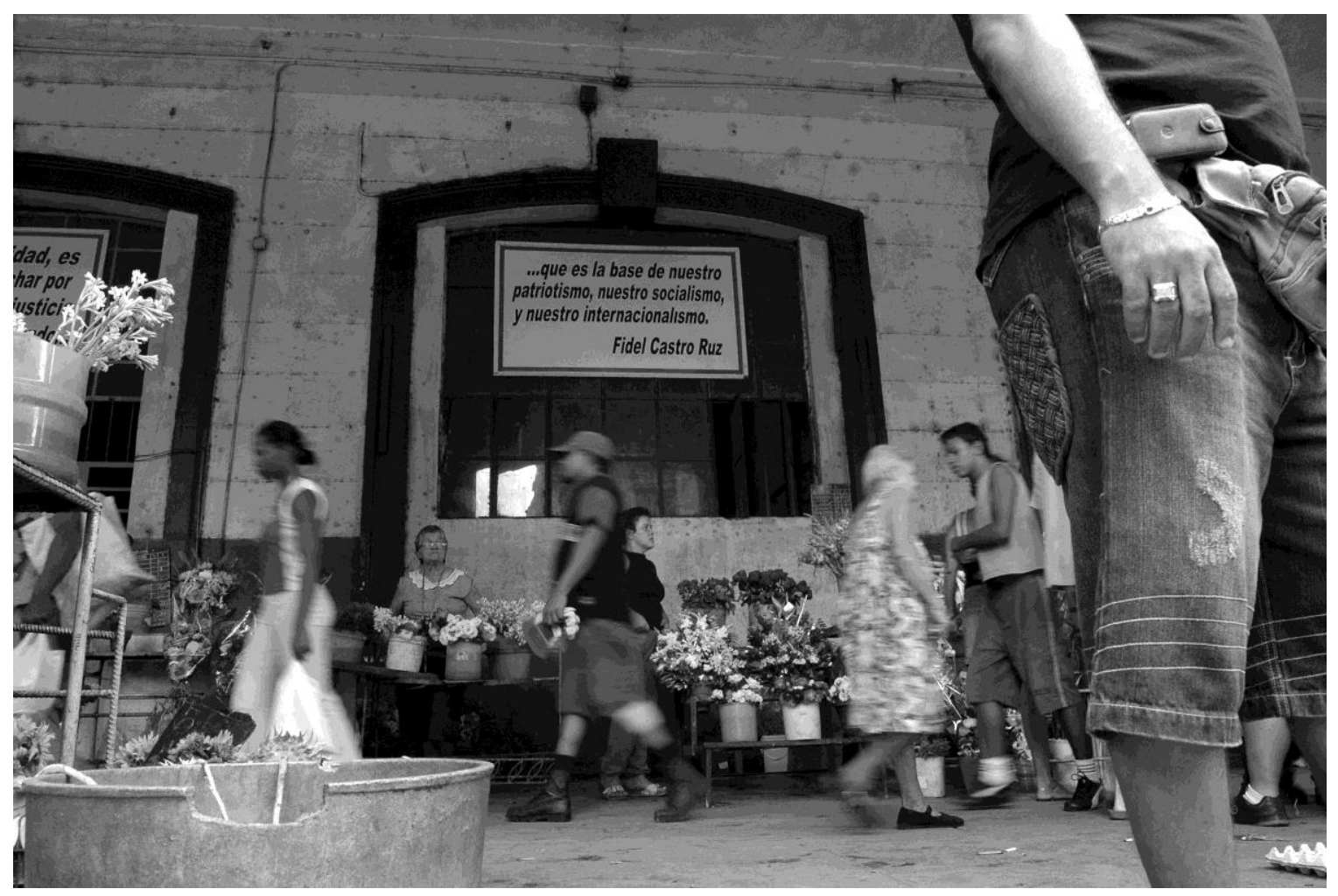

\section{PHOTOGRAPH 4.1}

Fidel at Cuatro Caminos. Fresh billboards with excerpts from one of el comandante's May Day speeches overlook the market portico, but nobody seems to notice them.

and the subsequent conversion of Elián into a political symbol, when families and children on the island were facing so much economic hardship. What bothered them was the distant state's seemingly contradictory misuse of the socialist commonwealth, not the socialist project as such. In this way, the ritual and symbolic energy of the state might successfully generate participation, and "solidarity" of a certain variety, but in a dissonant moral register.

My friends at Cuatro Caminos expressed this moral dissonance when billboards of a well-known Fidel speech went up throughout the plaza (as it turns out, this was the speech he delivered to the throngs in Havana on May 1, 2000, amid the Elián affair). 
Recall from the last chapter that Carlito pretended to ignore these quotations until he was moved to explain, in his view, what it really meant "to struggle with audacity." Most other workers in and around the agro, if they noticed these signs at all, complained that they squandered scarce building materials, inexplicably, in a time of great public need. Even state employees shared this view. When the signs were being mounted, I was interviewing two brothers who manned one of the few state-controlled tarimas in the plaza. They sold mangos at fixed rates but also participated in many of the same artful side businesses as their self-employed peers. "That is such stupidity," one of the brothers said, to no one in particular, while looking up at a large wooden sign as it was being hoisted in place. "With the loads of lumber that folks are lacking, the loads of paint that could be sold to folks for fixing up their houses, and look what they're doing with all that." This was the distant state — in the eyes of a state employee — at its most absurd. If Cuban enterprises had access to such useful goods, it was said, they should be providing those goods to the general populace, and at discount rates if possible. By this same logic, as we have seen, the appropriation of state goods through side channels was reimagined not as morally corrupt theft, but as everyday socialist "rectifications" of state socialist blunders.

\section{State Effects II: La Doble Moral, Inverted}

The lived experiences I have described so far suggest that the key symbolic projects of the Revolution often failed to fulfill their stated, intended effect, namely, the distant state's monopolization of moral authority. Sometimes the policies of the distant state 
were reinvented in an intimate reworking of their enforcement, as the previous chapter illustrates. In other cases — and sometimes simultaneously, in a vertiginous overlapping of moral paradigms — the deployment of its authoritative symbols and rituals generated experiences that were curiously at odds with both the morality of invention and the ideals of state socialism. Self-employed Cubans perceived this as a reflection of the distant state's own doble moral, its double standard or duplicity, borrowing the term directly from the discourse of social indiscipline already described above. In this section, I explore various ways in which la doble moral was seen reflected in the authoritative regime, not only in ritual practice but in the overtly economic enterprises of the distant state, and I consider how social actors variably internalized such contradictions.

Let us set the stage by returning briefly to the realm of state ritual. For one important celebration, several hundred high school and university students arrived to the city in buses from prestigious schools on the outskirts of Havana, including UCI, the prominent new computer science university; the selective V.I. Lenin secondary school; and a national institution for the study and production of fine art. These were all institutions that accepted students based on academic merit, as well as a consideration (or so it was said) of their standing in the UJC. The occasion, held on Jan. 7, 2008, was the forty-ninth annual celebration commemorating Fidel's entrance into the capital following the victory of rebel forces against the Batista regime. It took place along the bay in Old Havana, across from an imposing citadel dating back to the colonial era. I attended with two colleagues, one of whom happened to be a Cuban sociologist and the aunt of two students at V.I. Lenin. We sat near the back of the open-air forum on a mercifully cool night. 
Isabel, the sociologist, seemed to enjoy playing ethnographic observer along with me, commenting critically on the behavior of the young people around us with a twinkle in her eye. She likened them to captives who had come to identify with their kidnappers, for whom the experience was nevertheless an exhilarating departure from the usual humdrum of their lives.

"These are the 'distinguished' students," Isabel said, meaning they were chosen because they had not ruffled any political feathers at their respective institutions. "My niece and nephew are not here of course," she added, smiling. "They're not distinguished in that way."

A significant feature of the ritual for the young people in attendance — what they "really" got out of it, Isabel told me, recollecting her late teens and early 20 s — was a rare night out on the town and the feeling of being special; these were mostly well connected sons and daughters of party officials, she said. The ones near us carried on boisterously throughout the event, largely oblivious to the speeches, the traditional songs, and even the grand finale: an impressive show of fireworks launched over the bay as a tugboat illuminated with the words VIVA FIDEL floated by. Dressed in trendy European and U.S. brands, these students clearly had access to what, at the time, were considered luxury goods. One young woman fondled a cell phone. Another wore showy makeup and wielded a digital camera. Halfway through the ceremony, a young man in the group got up and announced he was headed off to look for snacks. He came back a few minutes later with lollipops bought from, as he put it, "some merolico over there" — no doubt one of the many unlicensed street vendors who always lingered on the outskirts of such 
events hoping to make a little extra money. As the loudspeakers crackled on, the woman with the camera took turns with her friends taking faux glamor portraits of each other. After a typical round of chants, giggling at herself, she mimicked the crier on stage in an exaggerated whisper: ";Viva Fidel!"

"Come on," one of her friends said, egging her on. "Do it for real." Everyone in the group laughed at the suggestion. Suddenly, they paused from their clowning to join the rest of the crowd in a spontaneous eruption of cheers for an artist who had soulfully improvised a Cuban grassroots musical style with lyrics about Fidel, using each letter in the name to praise el comandante's personal attributes: F for being a flare of reason, I for intelligence, D for devotion, E for eternity, and L "for the liberty he brought us from the mountain range." Unlike any other moment during the celebration, the performative flamboyance with which this sacred object was explicitly symbolized, and as symbol made anew, drew what seemed like genuine fervor. Isabel cheered as well. She said one had to admire such a fresh manipulation of an otherwise well-worn sign.

These observations are illustrative of an underlying state socialist meta-knowledge reproduced especially in ritual encounters that are not as massively engaging as elections or May Day celebrations. In this section, I show how these encounters with the state constitute special classes of people and consumptive notions of personhood. The expressive excess embedded in the horseplay described above was at one level the manifestation of youthful lightheartedness. But from a more removed vantage, it also reflected a notably privileged attitude toward the liturgies of the state in its distant form: the privilege both to publicly satirize ("up to a certain point"), indeed, to publicly satirize 
in the act of the ritual itself. To so relish in this meta-knowledge indexed the ritual participants' proximity to political power, and thus associated the distant state with individual style, material wealth and access to a consumer world beyond the reach of most Cubans, the temptations of which Fidel so often warned in his speeches. Indeed, this selective ritual participation naturalized social differentiation as emanating from the very center of power that claimed for itself the mission of abolishing class.

\section{Distant state: The nation as commodity}

The shifting focus of Cuban macroeconomic policy during the Special Period, as experienced in everyday life, has helped to cement differentiations of social class, and in very tangible ways. As we saw in the first chapter, the Cuban government turned to new sources of income in the Special Period, when Soviet subsidies dried up and the sugar industry essentially went bankrupt. Foreign tourism and foreign labor exchange together now account, officially, for the largest share of the gross domestic product. But off the books, cash and in-kind remittances from overseas — the total value of which recently surpassed $\$ 5$ billion a year - actually account for the largest source of income for the island's population of eleven million people (Morales and Scarpaci 2013). One survey shows that more than than two thirds of remittances come from the United States (Orozco and Hansing 2011; see Tables 1.1 and 1.2). Overall then, it can fairly be said that the Cuban national economy remains as dependent as ever on foreign trade and foreign connections, including the yanqui economy, and perhaps even more so now.

This reality has put the distant state in the awkward position of welcoming foreign capitalist investment and pushing lucrative trade deals while continuing to subscribe to a 
discourse of nationalism and socialist solidarity in the face of global capitalist penetration (see Powell 2008). In the biomedical fields, the government has sought to turn its knowledge-capital and scientific discoveries into wealth that might shore up the treasury with hard currency. In the process, it vigorously protects numerous patents on pharmaceutical drugs and medical techniques (for one such example, see FriedmanRudovsky 2013). While these actions are hailed in the state media as reasons for national pride, they are predicated on a notion of property rights that is ultimately rooted in the ideal of possessive individualism, where the nation-state stands in as a collective person in a free-market competition with its peers. The fact that the state held important patents on behalf of the Cuban people, many of my informants said, simply meant that the wealth this property generated — though it "belonged to all" — was monopolized in the halls of state power, and tended to benefit mostly the political elite.

Likewise, in the areas of artistic expression and conspicuous consumption, state officials market "Cuba" as a place and an idea of revolutionary dreams come true and delicious possibility. All the finest rum, tobacco and coffee are destined for export or tourist consumption, and all the finest hotels are accessible primarily to foreigners. Until mid-2008, Cubans were simply not allowed to enter tourist hotels, resorts and nightclubs, unless they worked there, whether they could afford admittance or not. During an academic seminar I attended in 2007 on the importance of the "culture of coffee" in Cuba, a high-level manager for the country's largest coffee enterprise discussed with enthusiasm the international cache of Cuba's home-grown gourmet coffees, somewhat to the chagrin of the seminar's attendees: none of those coffees were mass produced for 


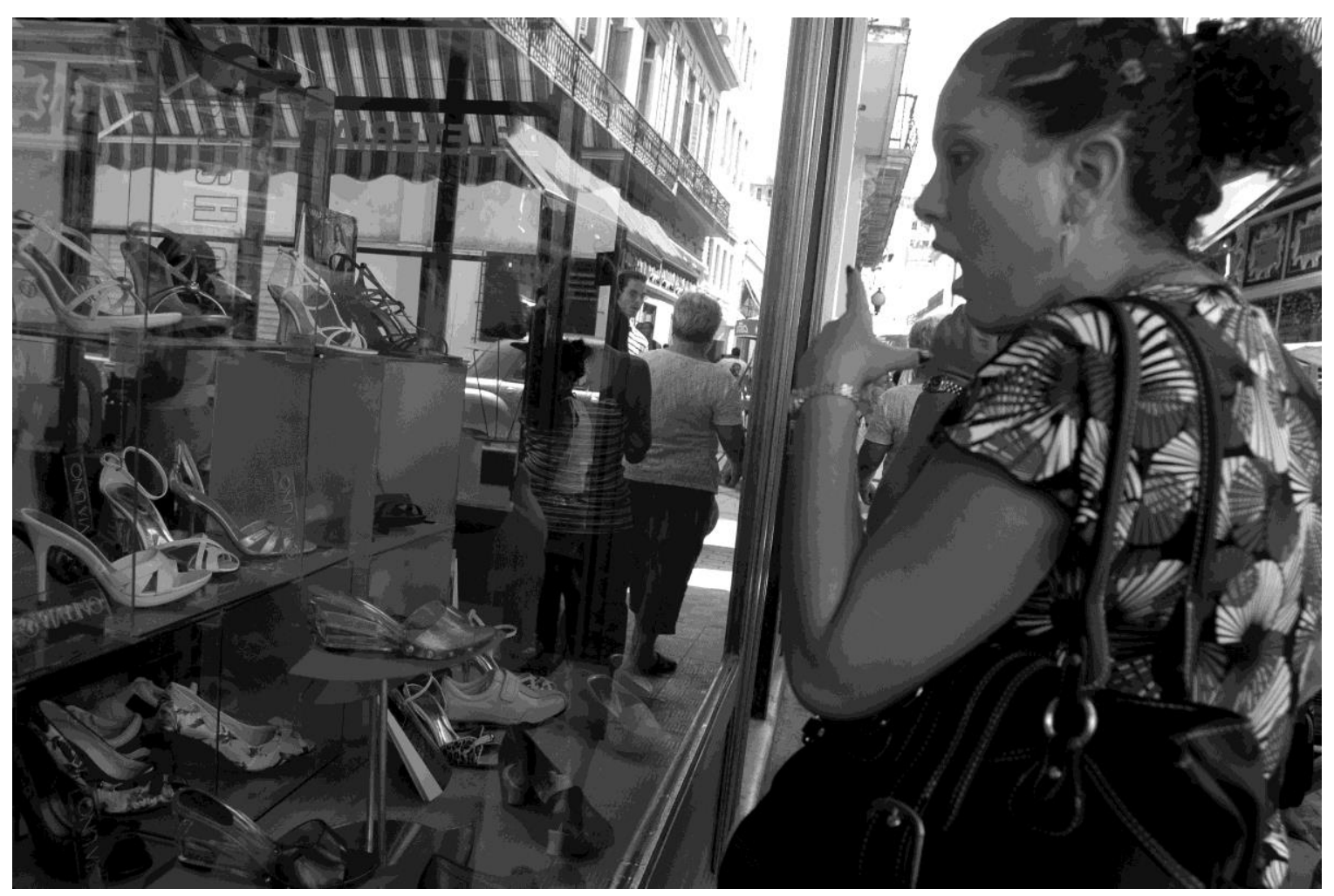

\section{PHOTOGRAPH 4.2}

Divisa store sticker shock. Designer shoes are sold in hard currency at state run stores like this one in Old Havana, but few Cubans can afford to buy them.

domestic consumption. And as everyone there knew — and the company official himself admitted — what was provided on the ration card was always cheap stuff imported from Vietnam, filled out with chickpea grounds to stretch its volume.

The government has not infrequently gone to court in venues abroad to protect its trademarks on tobacco and rum (e.g., AP 2013). It has also bestowed on accomplished musicians, artists and academics special privileges to travel and to market themselves and their work, in the interest of securing their art or research as part of the national patrimony. In an insightful critical essay, Hernández-Reguant (2004 :25) refers to this artistic cadre as the Revolution's “creator" class, writing that "in contrast to other 
workers, creators gained the ability to become rentiers, as their earnings were not tied to labor time or other moral standards but to the successful speculation of their labor products by corporate parties."

Meanwhile, physicians and other health professionals are sent abroad to Venezuela (and elsewhere in Latin America) in what has come to be known as the "oil for doctors" program. State media portray the program as humanitarian, but to many it is felt as a kind of exploitation of intellectual labor. On one hand, a "mission" assignment is a desirable, well paid post, while it lasts. On the other, Cubans are made to face difficult choices about leaving their families behind during those periods, with much of the financial benefit accruing, in their view, to the distant state - which is to say, the program is not felt in the ethos of solidarity that supposedly animates it. Among those eligible for the program, it is said the competition for acceptance is cutthroat and the motivations selfinterested. One physical therapist I knew, who in her off-hours helped her husband run a pirate taxi business in the invento market, told me she turned down an international mission offer for those very reasons. Her supervisors at the state health clinic where she worked part-time told her they thought she was crazy. But she said the pressure was too high, and the years it would drain away from a life with her husband and children weren't worth it.

My informants were far from oblivious to this contradiction, and they readily expressed frustrations with the way in which such realities touched their lives. In the case of tourism, two major state firms dominated the industry, both booking a variety of island tours, flights, diving excursions and hotel stays. Because one firm was overseen by the 
military and one was civilian, it was said that the first belonged to Raúl — who was chief of the armed forces — and the other belonged to Fidel. As for everyone else, the services these firms provided were for the most part off limits. Cubans were expected to vacation in separate state-run facilities, which they said were cramped, rustic and overbooked. To travel domestically, they could pay peso prices for flights, trains or bus rides, but they had to wait in long lines, get on passenger lists sometimes months in advance, and make do with lower-quality equipment. Even after Raúl Castro made it possible for Cubans with enough money to stay in divisa hotels, they faced suspicion. One friend told me, exasperated, that security guards turned her away from the shops at the Hotel Havana Libre (formerly the Hilton and a city landmark) because they assumed she was a jinetera, a prostitute who seeks out foreign customers and, ultimately, the opportunity to leave the country through marriage with a foreigner.

I heard many similar stories of painful confrontations with the tourism industry. Loreta, the ticket scalper we met in the previous chapter, raised two daughters largely in the shadow of Cuba's new tourism, making a living first in the resort town of Varadero, and then procuring and reselling ballet tickets and admissions to other major artistic events, in chavitos, to foreigners as well as relatively wealthy Cubans. In Havana she lived in a squalid tenement sandwiched, ironically, between two luxury hotels. To get to her apartment, you had to enter through a dark passageway, nearly invisible to the general public, threaded between a popular divisa cafe and the lobby of one of the hotels. Raising her girls in this environment, she said, it was a constant struggle to keep them from a life of prostitution, with so-called jineterismo (see Chapter 2) proliferating amid the influx of 
men and women, largely from Europe and Canada, seeking "exotic" sexual encounters (see also Rundle 2001). Being young, Afro-Cuban and attractive, Loreta's daughters were singled out for such behavior, and not infrequently hassled by the police simply for walking through their mother's neighborhood.

Once, Loreta told me, a German tourist propositioned her in the portico outside her building: "How much can I offer you to sleep with one of your daughters?" She was indignant. "You can sleep with me if you like," she told the man, "but my daughters aren't for sale." Interactions such at these led habaneros to comment from time to time that they felt like animals on display in a big zoo.

It was said that the state enterprises most connected to the tourist industry were the most corporatized and, though employees in this sector had treasured access to divisa tips and bonuses, these enterprises were also the most strictly operated. It was difficult, especially the higher one moved in the ranks, to follow the prescriptions of invento. These social sites represented, in effect, a pressure point between the distant and intimate forms of the state. For example, Ignacio, the bike mechanic, said he left a job overseeing a warehouse for foreign imports — goods destined for resort hotels — because it got "too complicated" to resolve things as his responsibilities increased. Another time, he illuminated a grievance I heard many times: that state workers who serve tourists resent what they do even if they appreciate the better pay, because it puts them directly into contact with wealth and privilege. In Ignacio's view, and that of many informants in the invento market, this fundamentally shifted such workers' moral compass. By way of explanation, Ignacio recounted how he and his wife had recently witnessed how a 
waitress serving tourists at Coppelia, Havana's most well-known ice cream parlor, tried to cheat her customers by confusing them about which currency — pesos or chavitos they should use. Far from an acceptable invento, Ignacio described this as proof of a twisted moral logic being produced via the contradictions of state tourism and the dual economy.

As we saw in the last chapter, Abel, Ignacio's bike shop partner, gave up a life working on cruise ships as part of a state contract with a foreign company. The pay was good and he received special in-kind bonuses from time to time when he returned to the mainland: for example, a motorcycle, designer-brand clothing, nice ties and leather shoes. The charm of this work came to an end, however, when he was summarily fired and sent home from a Mediterranean cruise at his own expense after being accused of bothering a female passenger and crank-calling her. Actually, Abel said, one of his bunkmates (another contract employee, from Honduras) had placed the call from their cabin, but the cruise line dismissed all four employees who bunked there, without having conducted a proper investigation. When Abel returned to Cuba, he visited the state enterprise that represented him, intending to file a complaint, only to be dismayed. "We're sorry," Abel recalled his Cuban supervisor saying. "What happened is a shame, but you're better off not pursuing this. This cruise line is a big company, and we have a major contract with them, and if we rock the boat, we could put the contract in jeopardy." This was not, Abel told me, what he understood "socialism" to be about. 


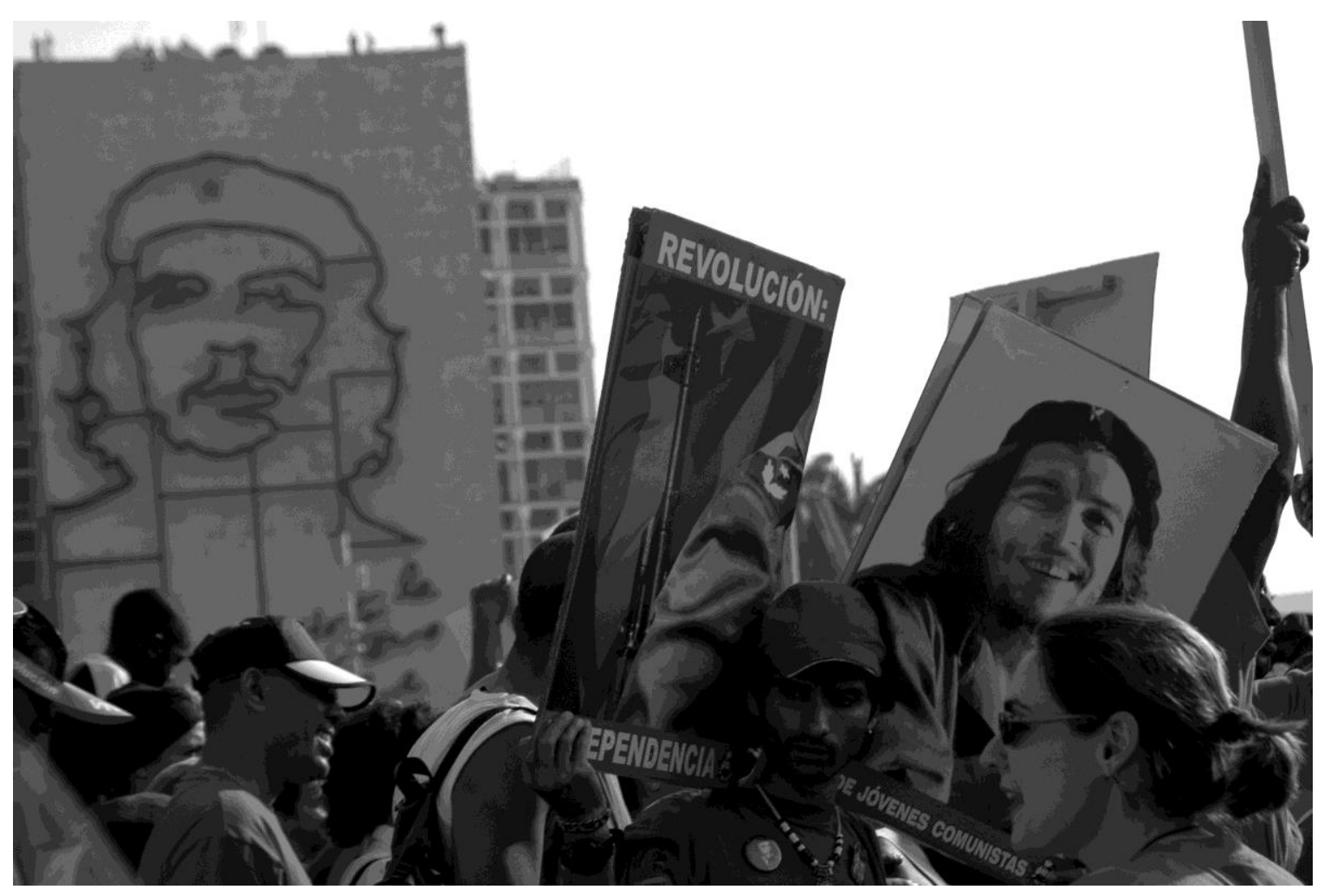

\section{PHOTOGRAPH 4.3}

Che as national symbol. Korda's image of Guevara on the façade of the Interior Ministry looks down on an official march in Revolution Square.

\section{Distant state: The Revolution as capital}

What has happened in Cuba to the symbol of Che is perhaps the most striking of such ironies. One classic image of Che Guevara, drawn from a photograph taken by Alberto Korda in 1960 and published only after Che's death, shows a stalwart Guevara in a soldier's beret, gazing intently just above and beyond the camera's point of view, dark hair frozen in a wispy tassel about his face. Known as Guerrero Heróico (Heroic Warrior), some claim this image, and variations of it, to be the most reproduced photograph of all time. It is commonly reprinted on T-shirts, murals, billboards, tattoos 
and armbands around the world. Perhaps the largest rendering of it is an outline of the portrait cast in steel and fixed nine stories high, on the façade of the headquarters of Cuba's Interior Ministry, overlooking Revolution Square in Havana. But during the Special Period the government has also worked to market this image to tourists, especially on colorful shirts available at quaint state-run divisa fairs in redeveloped zones of Havana and resort areas around the country. The success of this marketing effort is understandable given the iconic status this image has taken on, especially in developed countries, as a kind of radical-chic style, what some describe as a "cult of Che" (Kunzle 1997; for a collection of the many ways in which the image has been reproduced, see also Ziff 2002).

Despite Che Guevara's ubiquity in the national visual landscape, this cult of Che is notoriously absent from everyday life among Cubans themselves. One rarely sees anyone other than tourists wearing the Che T-shirts or the military berets they buy at premium divisa rates. In my experience, Cubans don't even talk much about Che. Although they learn in school about Guevara's life and his dedication to leftist causes, the details of this history are recalled only vaguely, much like cultural "knowing" anywhere. Meanwhile, my informants thought it was extremely funny that a certain meme had of late caught on among schoolchildren across the island: as I was told, youngsters had subtly modified a pledge chanted in the mornings. They were supposed to say "iSeremos como el Che!" ("We shall be like Che!”) but had converted that into ";Seremos como el Shrek!" And so it was that a Pixar character conceived in Hollywood had taken on greater significance among Cuba's young pioneros than the preeminent role model of the Revolution. 


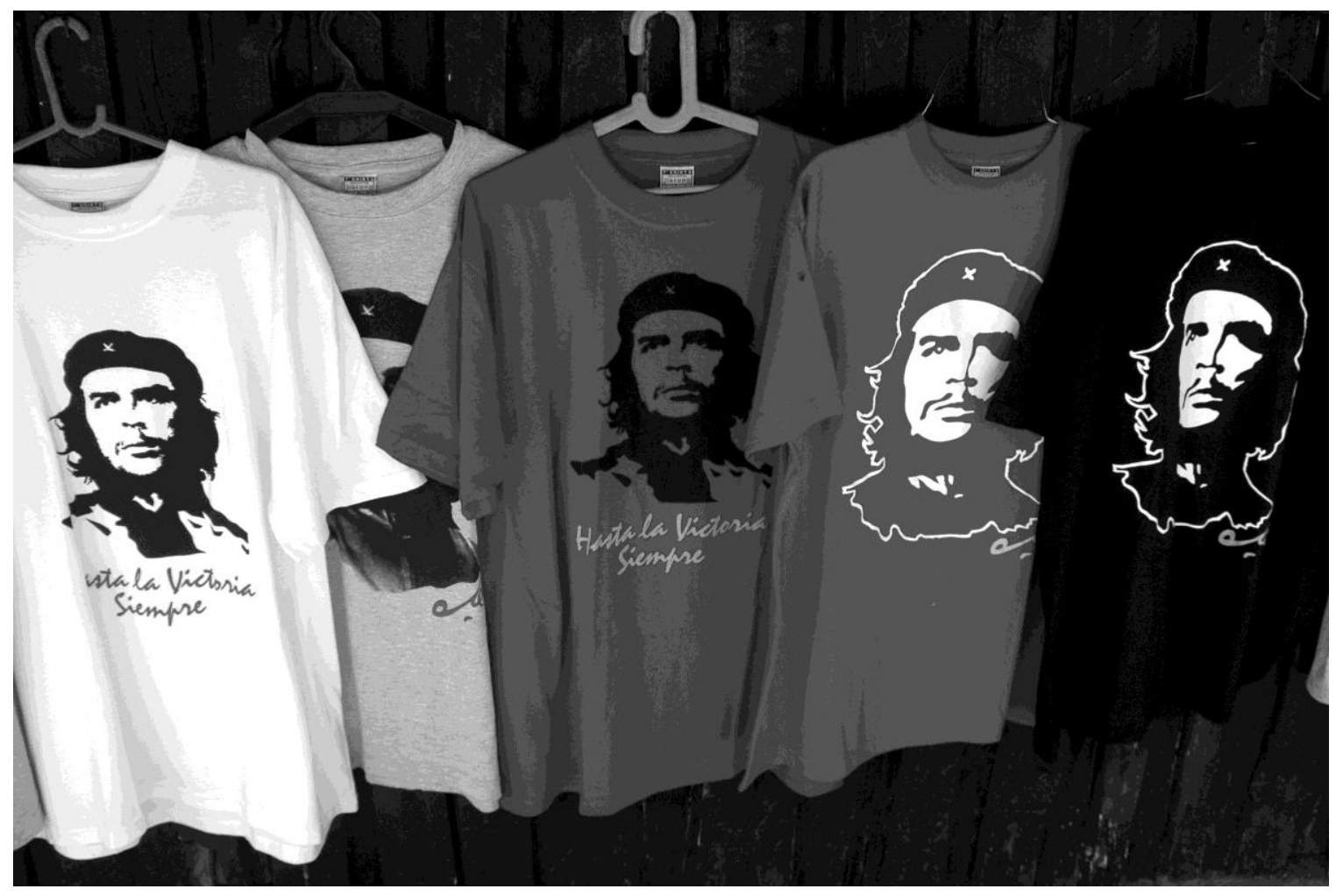

\section{PHOTOGRAPH 4.4}

Che as symbol of consumption. The same Korda image is reproduced for sale at state-run tourist fairs, for prices outside the reach of most Cubans.

Occasionally, however, I did see people sporting Che T-shirts, or images of other historically significant figures such as José Martí (the nineteenth-century Cuban revolutionary) or Camilo Cienfuegos (a rebel leader in the war against Batista). Whenever this happened, I used the opportunity to strike up a conversation with others about how they understood this sort of display, and what it meant to them. I learned that this symbolism - in part because it is rare - constitutes a satirical inversion of distantstate praxis, and so tells us something important about the politics of morality, a point worth elaborating in an extended analysis. 
My informants often said that such shirts were favored among male jineteros, not prostitutes per se but rather hustlers whose targeted foreigners for economic transactions on the left. Carlito, always the cynic, had an especially extreme version of this view. He said Revolutionary paraphernalia such as the Che image were chiefly favored among participants in the more dangerous categories of jineterismo, e.g., drug trafficking and prostitution — in other words, the most marginal and morally suspect kinds of invento. In Carlito's view, there was nothing whatsoever "political" in such displays by jineteros, in the sense that they could not care less about the authoritative meanings intended in such representations of the Revolution's historical figures. "They shit on the mothers of all those people," Carlito was wont to say. "But they know the police will annoy them a lot less if they walk around wearing a Che T-shirt."

I cannot say this hyperbolic view bore out in reality. But it was intelligible as satire because it referred to a more generally accepted — and, in my view, accurate — belief that wearing a Che T-shirt among ordinary Cubans did not imply any kind of devotion to the Revolution, and probably indicated some direct and sustained involvement in the invento market. Such shirts, after all, were expensive. If you had one you either had some money or (more likely) had received one as a gift, perhaps from a tourist befriended in some invento exchange. By contrast, among party loyalists such a display would be considered unnecessary and aesthetically gaudy; among those resolutely opposed to the system, of course, Che represents the very politics they decry, so wearing such a shirt, even as satire, would be considered anathema. Everyone else thus faced the problem of the possibility of "Che" indexing two precisely opposed ideologies, neither of which fit 
comfortably their politics of morality: it could mean you're "for" the system, or it could mean you're "against" it — and maybe a self-interested hustler to boot. And yet, precisely because of these contradictions, iconic images such as Che's provided an ideal pivot on which a critique of the distant state might turn.

The interlocking pieces of this ambiguous semiotic grammar help us understand why even among the vast numbers of people for whom the symbol of Che might be "open" for manipulation, the incidence of actually employing it was small. Beyond the danger of interpretation lies the simpler fact that, as the display of any icon becomes more regular and widespread, its value as a conduit for cultural critique diminishes, while its tendency to reproduce the object of its critique increases. Che can be lampooned, but only so much: what made this everyday satire meaningful was exactly how it contrasted with the omnipresence of the image in the authoritative discourse, and so challenged the distant state's ownership of the symbol, without subscribing to its dominant meanings. And the critique, in the final analysis, is this: "The state attacks the purported doble moral of our invento but exhibits its own doble moral in converting the image of its martyrs into commodities - and, what's more, capitalizes them as objective, valuable possessions of the nation. We, in our inventiveness, shun these corrupted icons - except when we choose (like the state) to instrumentalize them, for example, as a social amulet to protect against the capricious application of police force; at the same time we do this, we satirize the distant state, recolonizing Che, Martí, Camilo, and so on, as representative of the moral politics, and economic morality, of our competitive solidarity." In this way the socialist state's magical transformation of a revolutionary icon into capital is inverted in 
everyday praxis, by reconverting the commodified icon into a subaltern political tool, and a product of invention.

No one of course ever said such a thing to me in precisely those terms. Rather, this ethnographic interpretation flows from a close reading of what people in fact said and did — as well as what they were reluctant to say and do — in their daily lives. A particularly vivid exchange should help illustrate my reasoning. I had a long conversation one day about Che T-shirts with a young law student named Pedrito; he was Abel's stepson, and worked in his free time as a vendor at one of Abel's bicycle timbiriches near Cuatro Caminos. Pedrito was a soft-spoken and stylish guy who did not fit in very well with the rough-and-tumble crowd of the neighborhood. He liked to wear imitation Ray-Ban sunglasses and never dressed, like the mechanics who worked with his stepfather, in a jump suit or other tattered clothes. The conversation involved, in fact, the designer T-shirt he wore to work that day. It bore several large facsimiles of the Korda portrait of Che, etched in yellow on a field of crimson red. I asked Pedrito what this shirt meant to him. He stared at it, as if noticing for the first time that it bore Che Guevara's image. "Nothing," he said. Nothing? "Nothing," he insisted. "It doesn't mean anything to me. It's just a nice shirt I wear, just clothes I can put on, just something that fits me.” I pushed Pedrito on this, positing my theory that often when Cubans are wearing clothes that seem to express devotion to the Revolution they are doing so in a silent, even unconscious, form of sarcasm. "That's your opinion," he said.

I clarified myself. 'I'm not quite saying it's my opinion, I'm saying it's a hypothesis — it could be wrong or it could be right. What do you think?" 
"Well, that's fine," he said. "But it could be both right and wrong — depending on who you're talking to and what their thoughts and intentions are."

"Good point," I conceded. "So what are your thoughts and intentions when you wear Che's image on your chest?"

"I have no intentions," he said. "Like I say, it's just a shirt, a piece of clothing. My girlfriend gave it to me, and she got it from an international student, someone like you, actually, someone she met at the university."

The conversation went on like this for a while, until I remembered another gag Carlito liked to make about Che T-shirts and how they were viewed by the authorities, much to the amusement of his fellow tarima workers. The cops were ignorant enough, he would say, to assume that any shirt with someone's face on it was of revolutionary or popular ilk, and therefore deserving of their deference: "Those jineteros might as well wear T-shirts with George W. Bush on them," he would say. "The police are so stupid, they are capable of looking at it and thinking, that looks like someone I know. And then they'll say to the guy wearing it, trying to act cool, 'Compay, I liked that actor in that movie he made!'" What made this funny to everyone is that no one could fail to recognize that image of "Empire" most vilified in the Cuban press in the last few years. But behind this punch line was Carlito's point that in fact the signification of the image mattered.

With this in mind, I asked Pedrito, "Let's imagine that I give you a different shirt, but this one instead has a big smiling face of George Bush on it. It's in good condition, it fits you well. Would you wear it?" 
At first, to my surprise, Pedrito said yes, he would. I looked at him dubiously. Ignacio, who was listening to the exchange, said to Pedrito, "Come on man, stop eating shit,” meaning, “don’t bullshit us.” Before Pedrito could respond, I rephrased my question: "Suppose the T-Shirt had George Bush's picture and had written underneath it, MY HERO. Would you wear it then?"

"Of course not," he said. I peppered him with more nagging questions. Why not? After all, you could say it was a gift, you could say it meant "nothing," that it just fit you well... "Yes," Pedrito replied. "But what you wear — whether you like it or not — may lead other people to think certain things or make certain assumptions about you that you can't control. Even if the clothes mean nothing to you, you have to be aware of that."

"Exactly," I said. "So what's the difference between Che and Bush? Or better, let's go back to my first question, what is it that 'Che' means?"

"Well, unlike Bush, Che is dead, he can't do anyone any harm," he said. "Bush is still alive and has a very negative image. Che has a positive image as someone who dedicated himself to lofty ideals. But I'm not thinking of any of that when I wear this shirt."

“OK," I said. "And when do you wear it? Whenever you feel like it?”

"No," Pedrito said. "This is a shirt I wear to work." It became clear, as we continued talking, that he meant, exclusively, work at the bike shop. He told me he would never wear this kind of shirt to school, or in a state job, or in virtually any other context of his life. And yet, he insisted that Che "meant nothing" to him, never conceding otherwise. My point is that this apparent emptiness of meaning is in fact the subaltern meaning that in shielding himself with a symbol of the Revolution upon entering the world of 
invento, Pedrito was actively decoupling "Che" from the authoritative ground on which this icon rested, enacting the politics of invention. He couldn't control that Che's image was, in the authoritative sense, "positive," but the truth value of that proposition didn't matter to him. Indeed, saying that being dead, Che cannot do harm, implies that while alive he might have done harm. What mattered instead was that the proposition "Che is good" was known to be dominant, to enjoy the status of truth in the eyes of the powerful, therefore making it safe to wear Che and dangerous to wear Bush. Like Che himself, the icon had a certain lifeless quality: It had acquired a hegemonic meaning that could not simply be altered on a whim; as such it was out of the individual subject's control. But it could, in the deceptively simple act of wearing a certain T-shirt, if only from time to time and to work at a neighborhood bike shop, be emptied of its relevance.

\section{Distant state: The politics of consumption}

Earlier in this chapter, I narrated a neighborhood nominating election at length to illustrate the performance of obedient indifference and draw out its implications. Here, I turn to another ritual narrative to draw out how the distant state, in commodifying the nation and capitalizing the Revolution, is experienced as a consumptive state. That is, in ritual as well as prosaic experiences of the state, consumption and the modernist ideal of personhood on which consumption thrives are valorized.

During my extended stay in the field, I attended the thirty-first annual ceremony memorializing the bombing of a Cuban passenger jet. On Oct. 6, 1976, anti-Castro exiles secreted two timed explosive devices onto Cubana de Aviación Flight 455, en route from Barbados to Jamaica. The bombs detonated shortly after takeoff. Frantically, the pilots 
tried to turn the Douglas DC-8 back toward the runway, but it crashed in the sea. All seventy-eight people on board were killed, including the entire Cuban national fencing team, which had recently won a string of gold medals in international competition.

As it happens, my paternal grandfather's brother was among the dead. (He had been a career pilot for Cubana, but on that day he was not flying as a crew member.) My greatuncle's surviving relatives remain in Cuba and regularly participate in the official commemoration of this tragedy. It was thanks to them that I was able to attend both the public and private parts of the ceremony. However, I want to emphasize that the following description and analysis does not include or reflect their views, either about the bombing or the Cuban government, whose authority they fully respect.

Carried out by agents with CIA training, the bombing is part of the standard antiimperialist motif in the official media. Allusions to it are visible on billboards and other propaganda, and the public remembrance is covered extensively in the press. The victims are considered national heroes, and their surviving relatives are treated like VIPs even as they are expected (and indeed, pressured) to participate every year. In this particular year, the rhetoric surrounding the ritual was especially charged, because one of the men implicated in the Cubana bombing, Luis Posada Carriles, having escaped from prison in Venezuela, had recently attempted to sneak back into the United States on false pretenses and was being held in a Texas jail — on immigration and falsification rather than terrorism charges. (Carriles, who denies involvement in the bombing, was later acquitted at trial and has since moved back to Florida.) As we shall see, the ritual structure of this event recalls many aspects of the performative compliance that we saw in Cuban 
elections and other mass demonstrations organized by the state. At the same time, there are other aspects - especially the private procession and luncheon held for victims' families - that reveal surprising tendencies on the part of the distant state to commodify the tragedy.

The public portion of the ritual in 2007 began shortly after sunrise on a Saturday, at Havana's Anti-Imperialist Tribunal, a monument to martyrs of the Revolution with massive steel arches arrayed along the city's sea wall and pointed directly at the U.S. Interests Section, the former embassy. I joined my cousins and about two hundred relatives of the victims in an area designated specially for them.

By 8 a.m., underneath the arches of the tribunal, about one hundred students had been corralled from their university dormitories (as with the ceremony described earlier). They wore identical T-shirts bearing the initials of their school and held Cuban flags on large wooden poles. They looked tired, and some had fallen asleep slouched in their seats, with their flags half-draped over their bodies like blankets. But all stood at attention and raised up their flags, as if on cue, when a group of government dignitaries arrived on the scene and took their places near the stage. Below the stage, about 1,000 others huddled together in the shadow of Flag Hill, an imposing collection of one hundred thirty-eight ten-story banners, erected several years earlier to irritate officials of the U.S. diplomatic mission. This massive forest of flagpoles blocked from view an electronic display of scrolling text, often critical of the regime, which the Americans had installed on the side of the embassy building. 
As things were getting underway, a young man rallied the crowd in a series of the usual call-and-response chants: “;Viva Fidel! ¡Viva Raúl! ¡Viva el socialismo! Socialism or death! Country or death! Glory for the martyrs! We shall be victorious!” Rock music and salsa alternated in the background until a series of speeches began, scripted in the standard discourse of anti-Americanism, deriding U.S. intervention in Latin America in general and Cuba in particular. The speakers included a representative of the Cubana victims' association, the daughter of one of the five Cuban spies then serving prison terms in the United States, and, finally, Ricardo Alarcón, the president of the National Assembly at the time. (In the previous chapter, we witnessed his unusual encounter with a student of computer science, during a school assembly that was surreptitiously videotaped.)

Alarcón's intervention was the most polished and rhetorically practiced. While he seemed to speak off the cuff, in emphatic tones, the rhythm, structure and lexicology of his speech followed closely that of the authoritative discourse. He railed against "the imperialists," calling them "idiots" who had failed in their plan to demoralize the Cuban people, steeling their resolve instead. He drew the nation in a metaphor of kinship: "We are — all the Cuban family — family of the victims." But even as Alarcón delivered this impassioned performance, the young medical students standing near me were gossiping audibly in little circles about their personal intrigues, ignoring the hisses from an event usher urging them to keep it down. But they did not miss out on the chanting. When called upon, the rally-goers responded as if by reflex with gushing and, as far as anyone could tell, a sincere chorus of ;Viva! 
With the rally over, I joined my cousins in a comfortable air-conditioned van, one among dozens in a cavalcade arranged to transport them. Our next stop was Havana's vast urban cemetery, a city unto itself: the Christopher Columbus Necropolis. There, those killed on the Cubana flight share markers on a monument to the Revolution's military heroes. On the way, airline representatives from Cubana passed out complementary snacks to the relatives: specialty ham-and-cheese sandwiches on Kaiser rolls, sodas and bottled water, food items not readily available or affordable. We were still eating when the line of cars pulled into the cemetery through the main gate, an impressive marble archway dating to the late 1900s, adorned with Byzantine carvings. With midday approaching, the air was thick and hot, and we processed under a baking sun down the streets of the cemetery. Many participants from different families knew each other well from years of carrying out this duty together. They chatted as they strolled. It became clear to me that the occasion was as much a social event as it was a solemn remembrance. Every year these friends, connected only through the happenstance of tragedy, took the opportunity to catch up with one another. They seemed reluctant to let the seriousness of the occasion overwhelm them or to let it reopen their wounds, performing the overtly ceremonial parts, like the placing of a solitary rose at the markers bearing the names of their lost loved ones, with a labored display of grief. In private, they described the experience as something more like tedium than sadness.

"It's annoying," one woman told me. "But am I going to say, 'No I won't do this'?" In fact, not many years before she had said no, resisting the usual pressure to attend the 
day's events. With good reason: The ceremony that time around coincided with a rare trip overseas to visit a family member who had left Cuba.

At one point on our walk, a large man in a jumpsuit affiliated with the current Cuban fencing team moved through the crowd trying to stamp out the chitchat. "Silence!" he ordered gruffly. "This is a pilgrimage! You should walk in silence. The press is here!" Another relative gave me a look of frustration and, seemingly for my benefit, secretly stuck her tongue out at the fencing official. "He's not even one of the relatives!" she said. "What right does that guy have to tell me to shut up?"

This woman, Norma, lost an older brother on Flight 455. Later she told me how her own children weren't here with her because they had left the country some time ago, thanks in part to the important status her family enjoyed. Proudly, Norma exhibited her lightweight sandals, brought home from a visit she had made to one of her two sons in Europe. Back in the van, on the way to the banquet, she even took them off and thrust them in my hands, demanding that I behold their miraculous qualities. They cost a hundred euros, she announced — not so much gloating as incredulous at the very thought. "But somehow," Norma said, "they never get dusty. It's like they're immune to dust!" You can't find this stuff in Cuba, she whispered, then joined some of the other passengers in complaining about the snacks; the officials had distributed smaller portions than in previous years, they said. But there were other more onerous facets. During the rally, officials had passed out T-shirts depicting the bombing. The front of each bore the image of a Cubana jet with smoke billowing out of it, headed for the ocean. On the back it read in large block letters, WE DEMAND JUSTICE! The image, virtually identical to some 
of the billboards about the attack visible around town, struck many of the family members as needlessly graphic, but most felt compelled to wear it while walking on the procession, over their other clothes, despite the temperature. At the same time, the families also said they were happy to receive such regal treatment for a day, to ride in a comfortable vehicle for once and fly through busy intersections with police escorts.

Following the cemetery procession and some more speeches, the cavalcade of relatives traveled further outside the city center, down the coast to the Náutico yacht club. Once a private venue for elite Cubans in the pre-revolutionary era, the club facilities had seen better days, but the view of the sea they offered in the late afternoon was still striking, and that made this place special. At least, this was the intention - a treat for the families of national heroes. In the banquet hall, the victims' relatives dined with Cubana workers and police escorts. Other minders visited their tables, asking whether they needed anything. This sort of treatment, I should say, is largely unknown even to middleincome Cubans, since restaurants with Western-style service are outside their financial reach. While the guests of honor dined, the president of the victims' association updated them on esoteric bits of knowledge about the bombing, sharing what was currently known about its perpetrators. A French author friendly to the Revolution signed copies of his new book detailing the life of one of the alleged conspirators, speaking at length about it. Every family got a free copy.

But most paid little attention. They were focused instead on the ofertas. These "offerings" consisted of gourmet chocolates and other imported foods, as well as luxury cosmetic goods and toiletries otherwise available only in hard currency at divisa stores. 
The goods, priced at deep discounts in Cuban pesos, were piled on a table at one end of the hall. Many guests left with bags overflowing with this stuff. Several told me they wouldn't even use much of the ofertas themselves. Instead, they would sell it or give it away to friends. On the way home, Norma continued to gossip. She told me about infighting among certain families of the victims. She told me she thought the president of the association had used his position to gain prominence and personal benefits, like a good job at the foreign affairs ministry, one that was considered a steppingstone to a coveted overseas post. She admitted also that the travel opportunities she and her own children enjoyed had come in large part because they were related to a martyred son of the nation. Others remarked, even as they sighed about the imposition of such events in their private mourning, on what they viewed as clear "improvements" in the variety and quality of ofertas in recent years.

\section{The Subaltern 'Battle of Ideas'}

At the turn of the century, Fidel Castro began using the phrase "Battle of Ideas" as a strategic rally cry for all that the Revolution sought to promote as it transitioned past the Special Period (see Cameron 2006; Castro 2004; Flikke 2008; Font 2008; Kapcia 2009; Paz Ortega 2007). Beginning with the government's struggle to reclaim Elián González from his Miami relatives, this term has come to stand for almost every major government initiative and symbolic project, from the expansion of educational investment — such as the founding of the UCI — to the temporary curtailment of economic reforms initiated in the 1990s. The main themes of the discourse include promoting socialist consciousness, 
mass action through volunteer brigades and coordinated social work, the recentralization of the state, and internationalism through such programs as overseas health and sports missions. Font (2008) argues persuasively that the Battle of Ideas is reminiscent of previous efforts to "reinforce ideological orthodoxy," much like the Rectification period of the 1980s and the radical socialist reforms of the 1960s (see Chapter 2). While I disagree with Font's implicit assumption that a monolithic regime is fighting an impossible battle against the naturalness of capitalist markets, it cannot be denied that the Battle of Ideas is a trope conceived by and largely focused on Castro himself. As one New Yorker correspondent has noted, "many Cubans regard the Battle of Ideas as a spectacle they must tolerate but which is irrelevant to their lives" (Anderson 2006: 47).

Meanwhile, I have tried to show, their ambivalent relationship with the socialist state constitutes a subaltern battle of ideas. By showing how the moral universe of invento actively struggled with the authoritative discourse and ritual symbolism of the distant state, this chapter's "ethnography of the state" serves ultimately to complicate the weary and supercilious Western narrative of socialist totalitarianism, while at the same time unearthing an anthropologically informed critique of the communist project: As a statist utopia, socialism has never been able to transcend its modernist underpinnings, even as it has made possible meaningful alternative moral dispositions.

This more than anything is state socialism's deepest contradiction, and why in the twilight of all socialist revolutions the state apparatus has been the key purveyor of capitalist structures and policies, even as outside critics interpret such periods as capitalism breaking through among the masses. These readings are naive renditions of 
culturally loaded assumptions. Against these assumptions, my analysis of recent Cuban history and contemporary Cuban citizenship identifies a new fault line in the moral politics of everyday life under late socialism (and, for that matter, postsocialism): a rupture between what ordinary Cubans experience as the morality of invention and the morality, paradoxically, of capitalism. This politics of morality in turn produces a continual rupture in late socialist personhood. It produces, in effect, a "dual subjectivity." I expand on this notion in the following coda to this work. 
Nuestro pueblo tiene una sensibilidad muy grande para cualquier cosa mal hecha.

- Fidel Castro, 1962

\section{CodA: Reinventing CuBA, AND THE ANTHROPOLOGY OF POLITICAL ECONOMY}

Carlito disappeared toward the end of my fieldwork. As I readied things for my return to Virginia, I was away from the market for a few days tending to bureaucratic matters, compiling recent notes and interviews, visiting friends to thank them for their help and exchanging farewells. When I came back to Cuatro Caminos for a final round of goodbyes — the most difficult ones to be sure - I was expecting to find Carlito eager to unleash a barrage of wisecracks on the americano who had been pestering him for nearly two years. Maybe he would say that I had finally conceded defeat at the hands of the Revolution. I imagined him performing his best military voice with a twinkle in his eye:

"The invading imperialist forces have been overwhelmed! Patria o mиеrte, ¡venceremos!"

But he was gone. The drunk who had defended Carlito months earlier in his scuffle with Yoni was serving in his place as the tarima runner. Yoni, Carlito's boss and still his closest friend, would only say he had "taken some time off." But others in the agro told me privately that probably Carlito wasn't coming back. They said this in an oblique, vague way, in a way that made me think he had managed to arrange for a way out of Cuba, but also that I shouldn't ask about it. This was a plan that Carlito had talked about for a long time but which seemed to me mostly a dream to keep him occupied. Shortly 
after that, I left Havana, never having the chance to thank him or to share a few parting words. I've kept in touch with many of my contacts in Cuba, but I have not heard again from Carlito.

On reflection I should not have been so surprised. Carlito had been dropping hints. A few months before, he was explaining how smugglers ferry people across the Straits of Florida, directly to the United States, or westward to the Yucatán to make the rest of the way on land to a point of entry in Texas. There's no advance schedule, so prospective passengers have to be ready to go at a moment's notice. This was why he had, years earlier, given up operating a tarima on his own and gone to work for Yoni. In those days, the price for illicit passage off the island was as much as $\$ 10,000$ per person. And the risk was substantial. If you're caught on the high seas and sent back, Carlito said, the reprisals could be stringent — prison terms, police beatings, blacklisting for future jobs and selfemployment licenses. All this was said in one of his more manic moments, and, though I jotted it down, I didn't give the conversation much thought. When I looked back in my notes I remembered it was then that Carlito expressed his most explicit critique of state socialism. "Everything here is a lie," he said. "The system we have is broken. The economy is in total disarray, no one controls it."

Even in this short statement there is evidence of the dual subjectivity to which I referred at the end of the previous chapter. What belied the authoritative discourse for Carlito more than anything was the degree to which the invento market did a better job than the distant state of organizing social relations and economic activity in such a way that made everyday survival possible in a context of mutual solidarity. What made the 
system a failure was not the lack of a "free market" or excessive government "controls" on the economy, but the fact, as he put it, that no one seems to be in control anymore. The system had become utterly incoherent. Practically all cuentapropistas shared this view, if only a few like Carlito expressed it so bluntly. For some, a tortured departure made possible by the happenstances of history and favorable U.S. immigration policies for Cubans - was the only tenable resolution to the dual subjectivity that results. These are not the exiles of the 1960s, who imagined themselves fleeing the juggernaut of communism, but ambivalent émigrés caught between a socialism they cannot fully realize and a capitalism they cannot fully enjoy, and in fact do not fully wish to enjoy. For this reason, I agree with sociologists who say the new waves of Cuban expatriates in the United States are less like the exiles who preceded them and more like immigrants from other Latin American countries. But this is true in more than one sense. Although they come mainly seeking new economic opportunity rather than an escape from political persecution, they are seeking this from a very different ideological position (cf. EFE 2013a). This situation also helps to explain the paradox I framed at the start of this work: they are determined to leave, desperate to stay.

\section{Implications for Theory}

In this dissertation I have rehearsed the particularities of a set of market practices. In contemporary Cuba these go by the name invento. This native term captures how the selfemployed under late socialism think of their work and the social relations on which it depends - as contingent, creative, always and already culturally constructed. Among the 
peculiarities of invento so instructive for an anthropology of political economy is this native recognition that market exchange is not a feature of "the natural propensity of man," as Adam Smith would have it. Their market is not given but invented; their market is invented in the image of a certain if implicit set of moral propositions. This is true, I have argued, of all markets. In the invento market, as it turns out, the moral propositions at stake are especially visible because they contrast with the orthodox principles of market exchange as understood in the logic of capitalism. Small entrepreneurs in Havana and other metropolitan areas are doing markets and yet they are not doing capitalism not most of them anyway. Their market practices indeed inhibit the accumulation of material wealth. They compete: in the building of solidarity structures.

Competitive solidarity, I have demonstrated, has a specific political history and certain unusual political implications. It is a product of the Revolution's historical development. As a result of this history, it invokes not only socialist ideology but also a form of the radical nationalism the Revolution's leaders have from the very beginning espoused. Yet invento is deeply skeptical of state socialism, bureaucratic enforcement and modernity's mythology of progress. As a pragmatic politics — not a politics of resistance, it nevertheless stands in opposition to both actually existing capitalism and socialism, which in Cuba (as in Eastern Europe in the 1980s and 1990s) are increasingly converging.

I can now try to draw out more explicitly what this rereading of Cuba in the late Special Period does for a redirection of the anthropology of political economy. At the most basic level, my rereading contributes to a tradition of ethnographies that reveal the 
workings of culture "in the market." In that sense it advances a long history of anthropological critique aimed at neoclassical economics and the assumptions on which formal economic analysis rests. The Cuban cuentapropistas I knew were not irrational nor were they models of homo economicus.

But there is more to my argument than that. In adopting a sustained focus on one particular "invention of the market" I have tried to turn our attention to a category of action, which we can gloss as monetized commodity exchange, that in the anthropological literature has too easily been conflated with the cultural system of late modern capitalism. This conflation can be innocuous, even helpful, when talking about capitalist market exchange and its penetration across the globe. A problem arises however when anthropologists slip into a subtle form of the naturalistic economic assumptions we are otherwise experts in dismantling, by deploying the term market as an a priori category of human action that takes a timeless, placeless, formalized notion of capitalist exchange as its standard. Polanyi traced the development of the "false commodities" — land, labor and money — and concluded that the twentieth-century spread of markets for these commodities in particular constituted the great economic transformation of our time. We owe much to that analysis; it inspired a generation of social scientists to probe the devastating impacts of capitalist expansion on indigenous peoples. But as I suggested in my introduction, in articulating the historical process in this way Polanyi may well be to blame for inaugurating the essentialization of the market in the abstract for future anthropologists. While I am not the first to point this out, I am saying that I think this is a problem we have yet to resolve. 
For a good illustration of this problem I'll turn back for a moment to the work that Humphrey and Mandel (2002) have done in analyzing the experience of postsocialism. In closing Chapter 2, I turned to their incisive remarks to foreground the kind of moral ambiguities late socialist subjects have faced when they are forced to confront the reintegration of their worlds with the global capitalist order. In good anthropological fashion, Humphrey and Mandel make sure to qualify their observations with the caveat that actually existing economic relations never conform to formal, neoclassical models of economic man. In doing so, however, they still reproduce an image of "the market" — in spite of the appropriate scare quotes - confronting people, penetrating their experiences, setting up a "clash" with their "deeply ingrained moralities" (2002: 1). The analytical tension inherent in how we understand alternative moral-economic systems is palpable in a key excerpt from their remarks:

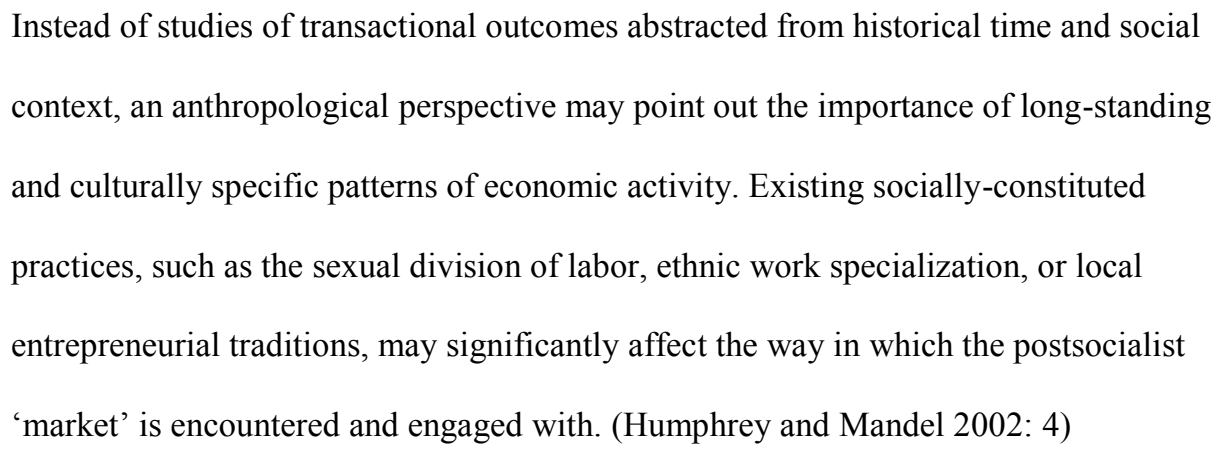

While this may not be the authors' intention, in construing a role for the discipline that pits "morality" against "the market," we risk giving up on deconstructing "the market" itself, and on the possibility of recolonizing the term market altogether. Humphrey, Mandel and their colleagues have demonstrated that postsocialist studies do have a 
lasting set of ideas to offer critical anthropological theory, a question that has been the subject of some recent, overwrought polemics (see Thelen 2011). They have shown, what's more, that this contribution can be made in the realm of political economy, which has so many significant implications for modern life, not only postsocialist contexts. In this respect, I have worked to push forward their analysis. What I am saying is that having paired "markets and moralities" what we now need are more clearly articulated ethnographies of "market moralities," and for that matter, "moral politics," in the plural.

Such an anthropology of political economy would not shy away from active involvement in our subject matter and with the world at large. Following Graeber (2001), I believe there is hope here for empirically informed social science to stand in opposition to the homogenizing structures of modernity. Examining the political consequences of culturally variable market action is one form of empiricism that could support the anthropology of political economy so framed. The good news is we need not vilify markets, or commodities, or money for that matter. The problem is not what people exchange, per se, or even the medium in which they exchange it. The proper problem of political economy has always been found in the relations of production and exchange that these things and processes reproduce. The market is not the problem. The problem is how we think about it — how indeed we invent it.

\section{Implications for Cuba}

Anthropologists tend to tread lightly where practical suggestions are concerned. For those who strike a more proactive tone, we tend to qualify them with labels: applied, 
engaged, public. There are reasons for this, historic and intellectual. Being relegated to the "savage slot" (Trouillot 2003), the discipline has never been able to muster much attention in public discourse about contemporary issues, except as the presumptive voices for indigenous tribes calling from the hinterlands, or as adventurous collectors of ancient artifacts and forensic experts whose research involves watching human bodies decay; in short, becoming ourselves curios of the academic world. Anthropologists also resist exposure in favor of detachment on ethical and scholarly grounds. It is one thing to analyze culture, quite another thing to try to change it. We are rightly wary of unintended consequences, "social engineering" gone horribly wrong, or just plain inefficacy.

For these reasons, I hesitate in making explicit policy recommendations. I make no claim to doing applied anthropology. I do however believe all anthropology should be applicable, as most of us implicitly do. And because I have made an explicitly political argument in this dissertation, it would be disingenuous not to stake out and defend something of a political position on Cuba, and U.S.-Cuba policy in particular. I come at this as best I can from the empirical demands as I see them.

Clearly, the embargo (or blockade, if you prefer) should be lifted. It has failed in its official intention to overthrow communism, a faulty goal from the beginning; surely contributed to the impoverishment of many millions; and all the while provided an authoritarian regime with greater legitimacy than it might otherwise enjoy. This view is widely held across the political spectrum — and widely held in Cuba! — and so it hardly requires a dissertation to be justified. The more crucial point then, is to find a way to lift the sanctions that appreciates the political complexities of their existence in the first 
place, as well as the social and political complexities of everyday life in Cuba, especially as I have detailed in my examination of invento.

What would this appreciation look like? One thought is that lifting sanctions should go hand-in-hand with a new regulatory regime that limits the extent to which American interests may invest in Cuba, channeling them especially toward new cooperatives and small enterprises on the island. Under new policy structures, the U.S. government could encourage microcredit for cuentapropistas, directing the resources of the expatriate community into programs that empower Cubans on the island rather than simply reappropriating wealth long since abandoned, or simply providing "free gifts" in the form of heavily taxed remittances.

Any such arrangements would of course require bilateral agreement. To that end full diplomatic relations between the two countries need to be restored as quickly as possible. This could happen overnight if the political will for it could be mustered. The Cuban government has a history of human-rights violations, this cannot be denied. But it is hypocritical to suggest that this — and not U.S. partisanship — is the underlying reason for a hugely asymmetrical relationship of aggression, especially in light of the fact that the United States happily does business with other, far more heavy-handed authoritarian regimes around the world. On the contrary, an appreciation of the past as well as the present might inspire U.S. leaders instead to apologize or at least publicly recognize the ugly history of American imperialism on the island, and the many absurdities of the Cold War that have influenced how we see Cuba. This admission can and should be accompanied, at long last, with the closing of the prison camp the U.S. military still 
operates at its base in Guantánamo Bay. The closing of the base itself, which exists on a dubious legal basis, would also make a lot of sense.

Given what little the Obama administration has done to modify Cuba policy, beyond making it easier for Americans to visit family on the island and send money, my critics could justifiably accuse me of hopeless idealism if not outright naiveté. The most meaningful politics is always hopeful. There is already some hope to speak of in the changes the Cuban government has implemented unilaterally in the last five years. Together they suggest that state leaders are increasingly aware of the dynamics I have described in this dissertation. And, it's true, they are probably deeply worried about their own future in a shifting political landscape.

The changes I am talking about have been amply covered in the press (e.g., Arlidge 2013; Burnett 2013a, 2013b; EFE 2011, 2013b; Frank 2013a, 2013b, 2013c; La Capital 2010; Miroff 2012). The government has begun once again issuing licenses for selfemployment, including more licenses for truckers who supply the farmers markets. By some counts, as many as one million Cubans are now officially involved in the cuentapropista universe. That's about nine percent of the country's population and represents a seventy-percent increase since 2009, according to Cuba's own statisticians. Agricultural raw materials, along with cars, homes, computers, cell phones and other electronics, may now be traded privately. More fallow land is being turned over to independent farmers and farming cooperatives. A new wholesale produce market has been turned over to cuentapropistas, and the first cooperative businesses outside of the farming sector have opened, including a hundred markets like the one at Cuatro Caminos 
that were still operated by the state and another twenty-six non-agricultural businesses. By setting up these new private enterprises as cooperatives, state leaders may be revealing that they understand how invento is as much about survival as it is about sustaining reciprocity and mutual support in a competitive marketplace.

Raúl Castro’s government has also taken certain small steps toward greater civil liberties and a more participatory democracy. A trenchant critique has been levied at the state press, for "ignoring" real problems in the system, and at government ministries and the party, for operating on the basis of extreme "secretism." The formal need to receive an exit visa to leave the island has been revoked, meanwhile, allowing all Cubans including self-declared dissidents and independent journalists — to travel overseas much more easily. In an announcement made as he began another term as president, Raúl Castro assured Cubans that he would term-limit himself and step down by February 2018. And yet it isn't at all clear how much these changes reflect a real awareness and concern for the plight of ordinary Cubans as opposed to a disingenuous effort to shore up the power and affluence of the party elite. Cuba's "reform czar" recently announced that even large state enterprises will be deregulated, including tourism ventures. Given the history in Eastern Europe of such firms falling directly into the hands of former government leaders, this should not necessarily be viewed as a welcome development. This is a possibility the Cubans I knew, already several years ago, eyed warily. In short, many unknowns remain. This much is sure: Only with diplomatic relations and a more humble foreign policy can the United States hope to influence anything like a positive outcome for ordinary Cubans in a sovereign, inventive Cuba. 


\section{The Good, the Bad and the Savage}

Not long before I left the island, I had many conversations with friends about two movies that had drawn packed crowds at Havana's International Film Festival in late 2007. The Lives of Others (Donnersmarck 2006) is an award-winning film set in East Germany in the 1980s. It tells the story of a playwright who, though sympathetic to communism, comes under Stasi surveillance and becomes disenchanted with the regime as it destroys his relationship with his lover. The second film, The Sugar Curtain (Guzmán 2007), is a documentary about life in Cuba at the apex of the Special Period, when transportation had virtually shut down and food shortages were at their worst. It was filmed by a Chilean woman who had grown up in Havana, exiled with her parents after leftist President Salvador Allende was deposed in a violent coup. Having left Cuba as a teenager, Guzmán dodged the worst of the 1990s. She returned years later, caught up with old friends, and found herself struggling to come to terms with a system that had sheltered and inspired her as a child but which seemed now to be failing its own ideals,

and her own. She narrates her passage through this new world and wonders if the Cuba of her childhood dreams ever really existed.

The subject matter of these films - one a historical fiction set in another country, the other almost too real to bear - differed substantially, but both of them resonated in similar ways. This resonance provides a telling window onto the dual subjectivity Cubans faced as the Special Period was closing. Guzmán's story elicited the melancholic pride of getting by in hard times, while The Lives of Others spoke to a common sense of disillusionment, the feeling of having been betrayed by the state while still dedicated to a 
sovereign nation and its radical social project. The fact that both movies met acclaim in Cuba, and were screened at all, shows that the duality that people live in late socialism cannot be suppressed. Festival organizers decided to screen The Lives of Others a second time after moviegoers complained they weren't able to see it the first time around. And The Sugar Curtain won the festival's award for best documentary. Guzmán herself appeared at the screening, at Havana's famed Cinema 23 y 12. She spoke at length about the making of the film and took questions from, a few of whom were the same childhood friends she had interviewed on camera. I attended with a close confidant, who noted without a hint of irony that the theater was probably stacked with state security agents.

Despite the crowds, probably only a few thousand Cubans in Havana attended the film festival. But like the video of the UCI student that circulated on the country's thumbdrive Internet, pirated copies of these movies soon made their way into Cuban homes. At Cuatro Caminos, I talked with Leticia, Mateo's wife, about The Sugar Curtain. She saw it on a DVD a friend had shared with her. "My heart tightened up when I saw that movie," she said. It brought to mind some of her own tribulations, which she recounted as we sat in her living room, austere but freshly painted with funds from her husband's auto-parts business and help from their business connections. In the 1990s she was still living in the central city of Santa Clara with her mother and sister. They ate a lot of boiled cabbage and squash — "morning, noon and night," Leticia repeated, several times — and sometimes grounded up the peals of plantains, frying them to make imitation beef. The CDRs were handing out bottles of multivitamins, and a leg of pork cost 1,500 pesos, about six months of the average state salary. "The day they announced on television that 
the agros were coming back, we were jumping for joy," Leticia said. The agro down the street from her home had since become a key to her family's survival.

Another friend, Ana, who lived in our neighborhood, chatted with me at length about The Lives of Others. We met one early evening a few blocks from my apartment in a city square lined with trees and flowers, where I often took Lucy and our adopted dog, Compay, to run around with the other dogs and children. Ana had several dogs of her own, and Lucy played fetch with them as we grownups debated the film. There was nothing like that in Cuba these days, I was certain - that level of systematic surveillance of which the Stasi were capable.

“No, you're wrong," Ana insisted matter-of-factly. "That's exactly how it is. They probably put cameras in your apartment, too. We assume we're being watched at all times — that's just normal."

I looked at her, incredulously. In the end, we agreed, we were both right. As a matter of technical capacity, there is no way the state security was watching everyone, or even cared to. On the other hand, the belief that this was possible contributed to a sense of vertigo, not unlike what I often felt as the quasi-native ethnographer, that shadowed the morality of invention in every instance. Nearly everyone had to participate in their own invento to get by, but also lived with the realization that the everyday moral universe of their own making could be held suspect — not, it must be said, by a nameless, faceless state, but a state made up of fellow socialist subjects, at once distant and intimate. The fact that Ana and I could have this conversation, and laugh casually about the implications of it as Lucy and our dogs frolicked in the waning daylight, is ironic only if 
we misread the actual challenge Cubans face and fail to understand the alternatives they are exploring for a better future.

It is not a future they wish to see in the hands of another capitalist oligarchy. Despite Fidel's long-held contempt for "things done badly" (see Castro 1962), this was precisely what many feared would be the Revolution's worst outcome. My friend Paco, the jackof-all-trades, liked to say he was by all means a revolutionary at heart. He had been a decorated militant of the Communist Youth. No, he no longer attended rallies or parades — he wasn't "up for that stuff” anymore, he said. But if he thought I was CIA, he once joked, he never would have let me into his house or introduced me to his family: "I'm no worm."

We shared coffee that day in the stately home he maintained (illegally) for a friend on an overseas mission. Paco had offered to help me repair the rusty gear train on my bicycle, and I came over to accept the favor. As usual, we could not get down to business without first talking for two hours about our views on the world. He spoke candidly, like many cuentapropistas, about the moral ambivalence Cubans felt on a daily basis, and about the best possible future they envisioned in a post-Castro world. Social justice, universal education at all levels, free health care, economic equity in the context of innovative business and competitive markets - none of these were in contradiction with each other, in his view.

"The problem is, he is terrified of anything that smells like capitalism," Paco said, stroking his chin in that iconic sign for el comandante. Even with Raúl Castro officially at the helm, the elder brother and the distant state remained synonymous. 
"Fidel has been a great political and military strategist, but when it comes to the economy he has been a disaster," Paco went on. "And the sad truth is that, because of this, we may end up with savage capitalism in the end. The kind of capitalism and intense consumerism you have over there in your country. Now, it's true, in this country we don't have complete freedom. You can't say that we do, compadre. It's not that I'm a counterrevolutionary or anything like that. I just think we should have the liberty to express what we want to express, to say this is good and that is bad. I'm not against the Revolution - I am against things done badly."

With that, Paco stepped out to the patio, pulled a wrench from his tool bag and set to work on my bike. 


\title{
References
}

\author{
Abrahams, Roger D.
}

1983 Symbolic Landscapes and Expressive Events. In The Man-of-Words in the West Indies. Baltimore: Johns Hopkins University Press.

Abu-Lughod, Lila

1990 The Romance of Resistance: Tracing Transformations of Power through Bedouin Women. American Ethnologist 17(1): 41-55.

Altman, J.

2009 The Hybrid Economy and Anthropological Engagements with Policy Discourse: A Brief Reflection. The Australian Journal of Anthropology 20(3): 318-329.

Anderson, Jon Lee

2006 Castro's Last Battle: Can the Revolution Outlive Its Leader? July 31: 44-55.

AP

2013 General Cigar puede usar nombre de Cohiba en EEUU. Associated Press, March 28.

Appadurai, Arjun

1986 Introduction: Commodities and the Politics of Value. In The Social Life of Things. Pp. 3-63. Cambridge: Cambridge University Press.

Arlidge, John

2013 Cuba, Home of the World's Oddest Property Market. Financial Times, June 21. 
Armengol, Roberto I.

2005 Making Cuba: The Anthropology of Fernando Ortiz. M.A. thesis, University of Virginia.

2010 Democracy as Game and Ritual: Notes on a Cuban Election. In Democracy and Personhood: Meditations on a Theme from Tocqueville. Annual Meeting of the American Anthropological Association, New Orleans, Nov. 21.

2011 Review of Cuba in the Shadow of Change: Daily Life in the Twilight of the Revolution, by Amelia Rosenberg Weinreb. American Ethnologist 38(4): 835-836.

2012 Introduction: Anthropology and the "Obscure Aspects of Social Life." In Recycling Mauss: "Old" Solidarities in New Times of Crisis. Annual Meeting of the American Anthropological Association, San Francisco, Nov. 18.

Austin-Broos, Diane

2009 Capitalism as Culture, and Economy. The Australian Journal of Anthropology 20(3): 301-317.

Ayorinde, Christine

2004 Afro-Cuban Religiosity, Revolution, and National Identity. Gainesville: University Press of Florida.

Baloyra, Enrique A., and James A. Morris, eds.

1993 Conflict and Change in Cuba. Albuquerque: University of New Mexico Press.

Barros, Sigfredo

2008 Béisbol: De cara a la finalísima; Pasión y cordura pueden ir de la mano. Granma, April 15: 3.

Bashkow, Ira

2004 A neo-Boasian Conception of Cultural Boundaries. American Anthropologist 106(3): 443-458.

Bengelsdorf, Carollee

1994 The Problem of Democracy in Cuba: Between Vision and Reality. New York: Oxford University Press. 
Benítez-Rojo, Antonio

1996 The Repeating Island: The Caribbean and the Postmodern Perspective. Durham: Duke University Press.

Berdahl, Daphne, Matti Bunzl, and Martha Lampland, eds.

2000 Altering States: Ethnographies of Transition in Eastern Europe and the Former Soviet Union. Ann Arbor, Mich.: University of Michigan Press.

Blum, Denise F.

2011 Cuban Youth and Revolutionary Values: Educating the New Socialist Citizen. Austin: University of Texas Press.

Bohannan, Paul, and George Dalton

1965 [1962] Introduction. In Markets in Africa: Eight Subsistence Economies in Transition; a New Selection. Paul Bohannan and George Dalton, eds. Pp. 1-32. Natural History Library. Garden City, N.Y.: Anchor Books.

Bosch, Carlos, and Josep María Domènech, dir.

2002 Balseros. Documentary. Bausan Films.

Bourdieu, Pierre

1977 Outline of a Theory of Practice. Cambridge, UK: Cambridge University Press.

Brathwaite, Edward Kamau

1974 Contradictory Omens: Cultural Diversity and Integration in the Caribbean. Kingston, Jamaica: Savacou Publications.

Brennan, Denise

2004 What's Love Got to Do with It? Transnational Desires and Sex Tourism in the Dominican Republic. Durham, N.C.: Duke University Press. 
Bronfman, Alejandra

2004 Measures of Equality: Social Science, Citizenship, and Race in Cuba, 1902-1940. Chapel Hill, N.C.: University of North Carolina Press.

Brookfield, H.C., ed.

1969 Pacific Market-Places; a Collection of Essays. Canberra: Australian National University Press.

Burawoy, Michael

1988 Piece Rates, Hungarian Style. In On Work: Historical, Comparative and Theoretical Approaches. R. E. Pahl, ed. Pp. 210-228. Oxford: Blackwell.

Burawoy, Michael, and Katherine Verdery, eds.

1999 Uncertain Transition: Ethnographies of Change in the Postsocialist World. Lanham, Md.: Rowman \& Littlefield.

Burnett, Victoria

2013a On May Day in Havana, a Nod to Capitalism. The New York Times, May 1.

2013b Slowly, Cuba Is Developing an Appetite for Spending. The New York Times, July 6.

Caldwell, Melissa L.

2004 Not by Bread Alone: Social Support in the New Russia. Berkeley, Calif.: University of California Press.

Cameron, Marce

2006 Cuba's Battle of Ideas. Green Left Weekly, May 10.

La Capital

2010 Raúl Castro defendió cambios en defensa del socialismo, Dec. 18. 
Carrier, James G., and Daniel Miller, eds.

1998 Virtualism: A New Political Economy. New York: Berg.

Castro, Fidel

1959 Discurso pronunciado en el Parque Céspedes. Santiago de Cuba, Jan. 1.

1961 Discurso pronunciado como conclusión. Reuniones con los intelectuales cubanos, efectuadas en la Biblioteca Nacional, Havana, June 30.

1962 Discurso pronunciado en el acto de graduación de 300 instructoras revolucionarias para las escuelas de domésticas, efectuado en el Teatro Chaplin, Havana, March 16.

1976 Report of the Central Committee of the Communist Party of Cuba to the First Congress Given by Comrade Fidel Castro Ruz, First Secretary of the Central Committee of the Communist Party of Cuba. First Congress of the Communist Party of Cuba, Havana, Dec. 17-22, 1975: Collection of Documents. Pp. 16-279. Moscow: Progress Publishers.

1988 Acto en conmemoración del XXXII aniversario del desembarco del "Granma" y de la fundación de las Fuerzas Armadas Revolucionarias, y la proclamación de Ciudad de La Habana Lista para la Defensa en la Primera Etapa, en la Plaza de la Revolución, Havana, Dec. 5.

1997 Acto central por el XXXV aniversario de la Unión de Jóvenes Comunistas, efectuado en el Teatro Carlos Marx, Havana, April 4.

1999 Sobre la emigración ilegal promovida durante 40 años por Estados Unidos contra Cuba. Matanzas, Cuba, March 8.

2004 Discurso pronunciado en la clausura. VIII Congreso de la Unión de Jóvenes Comunistas, Havana, Dec. 5.

2008a Voto unido. Granma, Jan. 10: 1.

2008b El voto unido: Una estrategia revolucionaria. Granma, Jan. 12: 1.

2008c El voto unido: Lo más importante es la participación. Granma, Jan. 15: 1.

2008d A los compatriotas de Occidente. Granma, January 20: 1.

Centeno, Miguel A.

2004 The Return of Cuba to Latin America: The End of Cuban Exceptionalism? Bulletin of Latin American Research 23(4): 403-413. 
Centeno, Miguel A., and Alejandro Portes

2006 The Informal Economy in the Shadow of the State. In Out of the Shadows: Political Action and the Informal Economy in Latin America. Patricia Fernández-Kelly and Jon Shefner, eds. University Park, Pa.: Pennsylvania State University Press.

Clastres, Pierre

1987 Society Against the State: Essays in Political Anthropology. New York: Zone Books.

Corbett, Ben

2004 This Is Cuba: An Outlaw Culture Survives. Cambridge, Mass.: Westview.

Couceiro, Avelino Víctor

2005 El mercado tiene Cuatro Caminos. Catauro 6(2): 95-123.

Cuba

1986 Plan de acción contra las irregularidades administrativas y errores del sistema de dirección de la economía. Havana.

Dalton, Thomas C.

1993 Everything Within the Revolution: Cuban Strategies for Social Development Since 1960. Series in Political Economy and Economic Development in Latin America. Boulder, Colo.: Westview Press.

Damon, Frederick H.

2003 What Good Are Elections? An Anthropological Analysis of American Elections 1(2): 38-82.

Das, Veena, and Deborah Poole

2004 Anthropology in the Margins of the State. School of American Research Advanced Seminar Series. Santa Fe, N.M.: School of American Research Press 
Deleuze, Gilles, and Félix Guattari

1987 A Thousand Plateaus: Capitalism and Schizophrenia. Brian Massumi, tran. Minneapolis: University of Minnesota Press.

Dilley, Roy, ed.

1992 Contesting Markets: Analyses of Ideology, Discourse and Practice. Edinburgh, UK: Edinburgh University Press.

von Donnersmarck, Florian Henckel, dir.

2006 The Lives of Others [Das Leben der Anderen]. Drama. Buena Vista International.

Drummond, Lee

1980 The Cultural Continuum: A Theory of Intersystems. Man 15(2): 352-372.

Duany, Jorge

2000 Nation on the Move: The Construction of Cultural Identities in Puerto Rico and the Diaspora. American Ethnologist 27(1).

Dunn, Elizabeth

1999 Slick Salesmen and Simple People: Negotiated Capitalism in a Privatized Polish Firm. In Uncertain Transition Ethnographies of Change in the Postsocialist World. Michael Burawoy and Katherine Verdery, eds. Pp. 125-150. Lanham, Md.: Rowman \& Littlefield.

Eastman, Brian

2009 Playing with Fire: Baseball and Moral Authority in Contemporary Cuba. Ph.D. Dissertation, University of Chicago.

EFE

2011 Granma critica increíble y hasta "enervante" secretismo en Cuba. El Nuevo Diario, July 9. 
2013a Cuban Expats in U.S. Becoming More Like Other Immigrants. EFE, May 27.

2013b Díaz-Canel llama a romper el "secretismo" de fuentes informativas en Cuba. El Nuevo Herald, July 5 .

Evans-Pritchard, E.E.

1954 Introduction. In The Gift: The Forms and Functions of Exchange in Archaic Societies. Marcel Mauss, author. Pp. v-x. London: Cohen and West.

Fagen, Richard R.

1969 The Transformation of Political Culture in Cuba. Stanford Studies in Comparative Politics. Stanford, Calif.: Stanford University Press.

Fernández, Damián J.

2000 Cuba and the Politics of Passion. Austin: University of Texas Press.

Fernández, Damián J., ed.

2005 Cuba Transnational. Nation Transnational. Gainesville: University Press of Florida.

Fernandez, James W.

1982 Bwiti: An Ethnography of the Religious Imagination in Africa. Princeton, N.J: Princeton University Press.

Firlit, Elizabeth, and Jerzy Chlopecki

1992 When Theft Is Not Theft. In The Unplanned Society: Poland During and after Communism. Janine R. Wedel, ed. Pp. 95-109. New York: Columbia University Press.

Flikke, Michelle Tisdel

2008 Review Essay: The Museum of the Battle of Ideas, Cardenas, Cuba. Museum Anthropology Review 1(1): 5-22. 
Font, Mauricio A.

2008 Cuba and Castro: Beyond the "Battle of Ideas." In Changing Cuba / Changing World. Pp. 43-72. New York: Bildner Center for Western Hemisphere Studies.

Foucault, Michel

1977 Discipline and Punish: The Birth of the Prison [Surveiller et Punir]. Alan Sheridan, tran. New York: Pantheon Books.

2006 [1991] Governmentality. In The Anthropology of the State: A Reader. Aradhana Sharma and Akhil Gupta, eds. Pp. 131-143. Malden, Mass.: Blackwell.

Frank, Andre Gunder

1966 The Development of Underdevelopment. Monthly Review 18(4): 17-31.

Frank, Marc

2013a Private Sector Bites into Cuban State Food Sales. Reuters, March 27.

2013b Cuba's Non-farm Co-ops Debut this Week Amid Move Toward Markets. Reuters, June 30.

2013c Cuba to Embark on Deregulation of State Companies. Reuters, July 8.

Frederik, Laurie A.

2012 Trumpets in the Mountains: Theater and the Politics of National Culture in Cuba. Durham, N.C.: Duke University Press.

Freeman, Carla

2000 High Tech and High Heels in the Global Economy: Women, Work, and Pink-collar Identities in the Caribbean. Durham, NC: Duke University Press.

Friedman-Rudovsky, Jean

2013 Blue Scorpion Venom: Cuba's Miracle Drug. Miami New Times, April 18. 
Fuente, Alejandro de la

2001 A Nation for All: Race, Inequality, and Politics in Twentieth-Century Cuba. Chapel Hill, N.C.: University of North Carolina Press.

Garces, Chris, and Alexander Jones

2009 Mauss Redux: From Warfare's Human Toll to L'homme Total. Anthropological Quarterly 82(1): 279-309.

Geertz, Clifford

1973 Thick Description: Toward an Interpretive Theory of Culture. In The Interpretation of Cultures: Selected Essays. Pp. 3-30. New York: Basic Books.

Gell, Alfred

1982 The Market Wheel: Symbolic Aspects of an Indian Tribal Market. Man 17(3). New Series: 470491.

Glissant, Édouard

1989 Theater, Consciousness of the People. In Caribbean Discourse. Charlottesville, Va.: University Press of Virginia.

Graeber, David

2001 Toward an Anthropological Theory of Value: The False Coin of Our Own Dreams. New York: Palgrave.

Gramsci, Antonio

2006 [1934] State and Civil Society. In The Anthropology of the State: A Reader. Aradhana Sharma and Akhil Gupta, eds. Pp. 71-85. Malden, Mass.: Blackwell. 
Greenhouse, Carol J.

2005 Hegemony and Hidden Transcripts: The Discursive Arts of Neoliberal Legitimation. American Anthropologist 107(3): 356-368.

Gregory, C.A.

1982 Gifts and Commodities. London: Academic Press.

1997 Savage Money: The Anthropology and Politics of Commodity Exchange. Amsterdam: Harwood Academic.

2009 Whatever Happened to Economic Anthropology? The Australian Journal of Anthropology 20(3): $285-300$.

Gropas, Maria

2007 The Repatriotization of Revolutionary Ideology and Mnemonic Landscape in Present-day Havana. Current Anthropology 48(4): 531-549.

Guerra, Lillian

2012 Visions of Power in Cuba: Revolution, Redemption, and Resistance, 1959-1971. Chapel Hill, N.C.: University of North Carolina Press.

Gupta, Akhil

2005 Narratives of Corruption: Anthropological and Fictional Accounts of the Indian State. Ethnography 6(1): 5-34.

2006 [1995] Blurred Boundaries: The Discourse of Corruption, the Culture of Politics, and the Imagined State. In The Anthropology of the State: A Reader. Aradhana Sharma and Akhil Gupta, eds. Malden, Mass.: Blackwell.

Guzmán, Camila, dir.

2007 The Sugar Curtain [El telón de azúcar]. Documentary. Wide Paraíso Productions. 
Hall, Stuart

1995 Negotiating Caribbean Identities. New Left Review 209(1): 3-14.

Handler, Richard

1988 Nationalism and the Politics of Culture in Quebec. Madison, Wis.: University of Wisconsin Press.

Hart, Keith

2007 Marcel Mauss: In Pursuit of the Whole; A Review Essay. Comparative Studies in Society and History 49(2): 473-485.

Harvey, David

2005 A Brief History of Neoliberalism. Alderman, New York: Oxford University Press.

Harvey, Penelope

1996 Hybrids of Modernity: Anthropology, the Nation State and the Universal Exhibition. London: Routledge.

Heidegger, Martin

1962 Being and Time [Sein Und Zeit]. John MacQuarrie and Edward Robinson, trans. 1st English ed. London: SCM Press.

Helg, Aline

1995 Our Rightful Share: The Afro-Cuban Struggle for Equality, 1886-1912. Chapel Hill, N.C.: University of North Carolina Press.

Henken, Ted A.

2002 Condemned to Informality: Cuba's Experiments with Self-Employment During the Special Period (the Case of the Bed and Breakfast). Cuban Studies 33: 1-29. 
Hernández-Reguant, Ariana

2004 Copyrighting Che: Art and Authorship Under Cuban Late Socialism. Public Culture 16(1): 1-29.

Herzfeld, Michael

2005 Political Optics and the Occlusion of Intimate Knowledge. American Anthropologist 107(3): 369376.

Hill, Matthew J.

2004 Globalizing Havana: World Heritage and Urban Redevelopment in Late Socialist Cuba. Ph.D. Dissertation, University of Chicago.

Humphrey, Caroline

1995 Creating the Culture of Disillusionment. In Worlds Apart: Modernity through the Prism of the Local. Daniel Miller, ed. Pp. 43-66. London: Routledge.

Humphrey, Caroline, and Ruth Mandel

2002 The Market in Everyday Life: Ethnographies of Postsocialism. In Markets and Moralities: Ethnographies of Postsocialism. Ruth Mandel and Caroline Humphrey, eds. Pp. 33-51. Oxford, UK: Berg.

Kaneff, Deema

2002 The Shame and Pride of Market Activity: Morality, Identity and Trading in Postsocialist Rural Bulgaria. In Markets and Moralities: Ethnographies of Postsocialism. Ruth Mandel and Caroline Humphrey, eds. Pp. 33-51. Oxford, UK: Berg.

Kapcia, Antoni

2009 Batalla de Ideas: Old Ideology in New Clothes? In Changing Cuba / Changing World. Mauricio A. Font, ed. Pp. 73-88. New York: Bildner Center for Western Hemisphere Studies. 
Kertzer, David I.

1988 The Virtues of Ambiguity. In Rituals, Politics, and Power. Pp. 57-76. New Haven, Conn.: Yale University Press.

Kornai, János

1980 Economics of Shortage. Contributions to Economic Analysis. Amsterdam: North-Holland Publishing Co.

Kunzle, David

1997 Che Guevara: Icon, Myth, and Message. Los Angeles: UCLA Fowler Museum of Cultural History.

Lampland, Martha

1991 Pigs, Party Secretaries, and Private Lives in Hungary. American Ethnologist 18(3): 459-479.

1995 The Object of Labor: Commodification in Socialist Hungary. Chicago: University of Chicago Press.

Ledeneva, Alena V.

1998 Russia's Economy of Favours: Blat, Networking, and Informal Exchange. Cambridge, UK: Cambridge University Press.

Leiner, Marvin

1994 Sexual Politics in Cuba: Machismo, Homosexuality and AIDS. Boulder, Colo.: Westview Press.

Lévi-Strauss, Claude

1966 The Science of the Concrete. In The Savage Mind. Pp. 1-33. Chicago: University of Chicago Press. 
Li, Tania Murray

2005 Beyond "the State" and Failed Schemes. American Anthropologist 107(3): 383-394.

Liebersohn, Harry

2011 The Return of the Gift: European History of a Global Idea. Cambridge, UK: Cambridge University Press.

Linger, Daniel Touro

2001 No One Home: Brazilian Selves Remade in Japan. Stanford, Calif.: Stanford University Press.

Lomnitz-Adler, Claudio

2001 Deep Mexico, Silent Mexico: An Anthropology of Nationalism. Minneapolis: University of Minnesota Press.

Malinowski, Bronislaw

1922 Argonauts of the Western Pacific: An Account of Native Enterprise and Adventure in the Archipelagoes of Melanesian New Guinea. London: Routledge.

Mallard, Grégoire

2011 The Gift Revisited: Marcel Mauss on War, Debt, and the Politics of Reparations. Sociological Theory 29(4): 225-247.

Mandel, Ruth, and Caroline Humphrey, eds.

2002 Markets and Moralities: Ethnographies of Postsocialism. Oxford, UK: Berg.

Marcus, George E., and Michael M. J. Fischer

1986 Anthropology as Cultural Critique: An Experimental Moment in the Human Sciences. Chicago: University of Chicago Press. 
Mauss, Marcel

1990 [1925] The Gift: The Form and Reason for Exchange in Archaic Societies. H.D. Halls, tran. New York: Norton.

Mayoral, María Julia

2008 Votar por todos. Granma, Jan. 15: 2.

McKay, Deirdre

2009 Performing Economy Differently: Exploring Economic Personhood and Local Economic Diversity. The Australian Journal of Anthropology 20(3): 330-346.

Merlan, Francesca

2009 Introduction: Recuperating Economic Anthropology. The Australian Journal of Anthropology 20(3): 269-284.

Metcalf, Peter

2002 They Lie, We Lie: Getting on with Anthropology. London: Routledge.

Mintz, Sidney W.

1974 The Caribbean Region. Daedalus 103(2): 45-71.

1985 Sweetness and Power: The Place of Sugar in Modern History. New York: Viking.

Miroff, Nick

2012 Havana Market Offers Cuba a Taste of Capitalism in the Dark. GlobalPost, Dec. 31.

Mitchell, Timothy

1990 Everyday Metaphors of Power. Theory and Society 19(5): 545-577. 
1999 Society, Economy, and the State Effect. In State / Culture: State Formation after the Cultural Turn. George Steinmetz, ed. Pp. 76-97. Ithaca, N.Y.: Cornell University Press.

Moore, Robin

2006 Music and Revolution: Cultural Change in Socialist Cuba. Berkeley, Calif.: University of California Press.

Morales, Emilio, and Joseph L. Scarpaci

2013 Remittances Drive the Cuban Economy. Miami: The Havana Consulting Group.

Moreno, José A.

1998 Cuba, Período Especial: Perspectivas. Ediciones Políticas. Havana: Editorial de Ciencias Sociales.

Mueggler, Erik

2001 The Age of Wild Ghosts: Memory, Violence, and Place in Southwest China. Berkeley, Calif: University of California Press.

Müller, Birgit

1991 Toward an Alternative Culture of Work: Political Idealism and Economic Practices in West Berlin Boulder, Colo.: Westview Press.

Nugent, David

1994 Building the State, Making the Nation: The Bases and Limits of State Centralization in "Modern" Peru. American Anthropologist 96(2): 333-369.

Olshan, Marc A.

1998 Inventing Life in Cuba: The Cuban People Survive Not Because of Their Government's Policies but Despite Them. The Freeman, April 1: 196-199. 
Ortiz, Fernando

1940 Contrapunteo cubano del tabaco y el azúcar. Havana: Jesús Montero.

1973 Órbita de Fernando Ortiz. Julio Le Riverend, ed. Havana: Unión de Escritores y Artistas de Cuba.

Orozco, Manuel, and Katrin Hansing

2011 Remittances Recipients and the Present and Future of Micro-Entrepreneurship Activities in Cuba. Cuba in Transition 21: 302-308.

Parry, Jonathan, and Maurice Bloch, eds.

1989a Money and the Morality of Exchange. Cambridge, UK: Cambridge University Press.

1989b Introduction: Money and the Morality of Exchange. In Money and the Morality of Exchange. Jonathan Parry and Maurice Bloch, eds. Pp. 1-32. Cambridge, UK: Cambridge University Press.

Pascual Díaz, Leocadio

1992 La disciplina laboral, su origen, desarrollo y perspectiva. Revista Cubana de Derecho IV(5): 97 112.

Paz Ortega, Manuel

2007 "The Battle of Ideas" and the Capitalist Transformation of the Cuban State. International Viewpoint, Feb, 8.

Peláez, Orfilio

2012 ¡Playas del Este en apuros! News archive. Portal Cuba.

Pérez, Lisandro

1986 Cubans in the United States. The Annals of the American Academy of Political and Social Science 487(1): 126-137. 
Pérez, Louis A., Jr.

1999 On Becoming Cuban: Identity, Nationality, and Culture. Chapel Hill, N.C.: University of North Carolina Press.

2008 Cuba in the American Imagination: Metaphor and the Imperial Ethos. Chapel Hill, N.C.: University of North Carolina Press.

2011 Cuba: Between Reform and Revolution. New York: Oxford University Press.

Pérez-López, Jorge F.

1995 Cuba's second economy: From behind the scenes to center stage. New Brunswick, N.J.: Transaction Publishers.

Pérez-Sarduy, Pedro, and Jean Stubbs

2000 Afro-Cuban Voices: On Race and Identity in Contemporary Cuba. Gainesville, Fla.: University Press of Florida.

Pérez-Stable, Marifeli

1999 The Cuban Revolution: Origins, Course, and Legacy. New York: Oxford University Press.

Peters, Philip

2000 The Farmer's Market: Crossroads of Cuba's New Economy. Arlington, Va.: Lexington Institute.

Phillips, Emma F.

2007 "Maybe Tomorrow I'll Turn Capitalist": Cuentapropismo in a Workers' State. Law \& Society Review 41(2): 305-342.

Pine, Frances

2002 Retreat to the Household? Gendered Domains in Postsocialist Poland. In Postsocialism: Ideals, Ideologies, and Practices in Eurasia. C.M. Hann, ed. London: Routledge. 
Polanyi, Karl, Conrad M. Arensberg, and Harry W. Pearson, eds.

1957 Trade and Market in the Early Empires: Economies in History and Theory. Glencoe, Ill.: Free Press.

Powell, Kathy

2008 Neoliberalism, the Special Period and Solidarity in Cuba. Critique of Anthropology 28(2): $177-$ 197.

Premat, Adriana

2012 Sowing Change: The Making of Havana's Urban Agriculture. Nashville: Vanderbilt University Press.

Reed, Gail

2012 Revolutionizing Gender: Mariela Castro, MS, Director, National Sex Education Center, Cuba. MEDICC Review 14(2): 6-9.

Richman, Karen E.

2005 Migration and Vodou. Gainesville: University Press of Florida.

Robins, Nicholas A.

2003 The Culture of Conflict in Modern Cuba. Jefferson, N.C.: McFarland \& Co.

Robotham, Don

2005 Culture, Society, and Economy: Bringing Production Back In. London: Sage Publications.

Rodríguez-Mangual, Edna M.

2004 Lydia Cabrera and the Construction of an Afro-Cuban Cultural Identity. Chapel Hill, N.C.: University of North Carolina Press. 
Rose, Nikolas, and Peter Miller

1992 Political Power Beyond the State: Problematics of Government. The British Journal of Sociology 43(2): 173-205.

Rosendahl, Mona

1997 Inside the Revolution: Everyday Life in Socialist Cuba. Ithaca, N.Y.: Cornell University Press.

Rundle, Mette Louise B.

2001 Tourism, Social Change, and Jineterismo in Contemporary Cuba. In Society for Caribbean Studies Conference, University of Nottingham, UK, July.

Sahlins, Marshall

1972 Stone Age Economics. Chicago: Aldine.

1976 Culture and Practical Reason. Chicago: University of Chicago Press.

1985 Islands of History. Chicago: University of Chicago Press.

2004 Apologies to Thucydides: Understanding History as Culture and Vice Versa. Chicago: University of Chicago Press.

Sánchez, Oscar

2008 La indisciplina social es el cáncer de la sociedad. Granma, Feb. 26: 3.

Sanford, Victoria

2004 Contesting Displacement in Colombia. In Anthropology in the Margins of the State. Veena Das and Deborah Poole, eds. Pp. 253-277. School of American Research Advanced Seminar Series. Oxford, UK: School of American Research Press.

Sapir, Edward

1934 The Emergence of the Concept of Personality in a Study of Cultures. The Journal of Social Psychology 5(3): 408-415. 
Schrift, Alan D.

1997 The Logic of the Gift: Toward an Ethic of Generosity. New York: Routledge.

Scott, James C.

1985 Weapons of the Weak: Everyday Forms of Peasant Resistance. New Haven, Conn.: Yale University Press.

1990 Domination and the Arts of Resistance: Hidden Transcripts. New Haven, Conn.: Yale University Press.

1998 Seeing Like a State: How Certain Schemes to Improve the Human Condition Have Failed. New Haven, Conn: Yale University Press.

Shryock, Andrew

1997 Nationalism and the Genealogical Imagination: Oral History and Textual Authority in Tribal Jordan. Berkeley, Calif.: University of California Press.

Sigaud, Lygia

2003 The Vicissitudes of The Gift. Social Anthropology 10(03): 355-358.

Sivaramakrishnan, K.

2005 Some Intellectual Genealogies for the Concept of Everyday Resistance. American Anthropologist 107(3): 346-355.

Smith, Adam

1776 An Inquiry into the Nature and Causes of the Wealth of Nations. London: W. Strahan and T. Cadell.

Spivak, Gayatri Chakravorty

1996 The Spivak Reader: Selected Works of Gayatri Chakravorty Spivak. Donna Landry and Gerald M. MacLean, eds. New York: Routledge. 
Stark, David, and Victor Nee

1989 Toward an Institutional Analysis of State Socialism. In Remaking the Economic Institutions of Socialism: China and Eastern Europe. Victor Nee and David Stark, eds. Pp. 1-31. Stanford, Calif.: Stanford University Press.

Stewart, Alison

2008 Cubans Talk Baseball, Not Castro, on the Street. Interview with Roberto I. Armengol. The Bryant Park Project, National Public Radio, Feb. 20.

Sullivan, John Jeremiah

2012 Where Is Cuba Going? The New York Times, Sept, 20.

Szelényi, Iván

1988 Socialist Entrepreneurs: Embourgeoisement in Rural Hungary. Cambridge: Polity.

Taylor, Charles

2004 Modern Social Imaginaries. Durham, N.C.: Duke University Press.

Thelen, Tatjana

2011 Shortage, Fuzzy Property and Other Dead Ends in the Anthropological Analysis of (Post)Socialism. Critique of Anthropology 31(1): 43-61.

Thomas, Hugh

1998 Cuba, or, The Pursuit of Freedom. New York: Da Capo Press.

Thompson, E.P.

1971 The Moral Economy of the English Crowd in the Eighteenth Century. Past \& Present(50): 76-136. 
Triana Cordoví, C. Juan

2012 De la economía sumergida a la microempresa: ¿Hay garantías a futuro? Desde la Isla. Washington, D.C.: Cuba Study Group.

Trouillot, Michel-Rolph

2001 The Anthropology of the State in the Age of Globalization. Current Anthropology 42(1): 125-138.

2003 Anthropology and the Savage Slot: The Poetics and Politics of Otherness. In Global Transformations: Anthropology and the Modern World. Pp. 17-44. New York: Palgrave Macmillan.

Turner, Victor W.

1967 The Forest of Symbols: Aspects of Ndembu Ritual. Ithaca, N.Y.: Cornell University Press.

1957 Schism and Continuity in an African Society: A Study of Ndembu Village Life. Manchester, UK: Manchester University Press.

Verdery, Katherine

1991a National Ideology Under Socialism: Identity and Cultural Politics in Ceauşescu's Romania. Berkeley, Calif.: University of California Press.

1991b Theorizing Socialism: A Prologue to the "Transition.” American Ethnologist 18(3): 419-439.

1996 What Was Socialism, and What Comes Next? Princeton, N.J.: Princeton University Press.

Wagner, Roy

1975 The Invention of Culture. Englewood Cliffs, N.J.: Prentice-Hall.

Wallerstein, Immanuel M.

1974 The Modern World-System: Capitalist Agriculture and the Origins of the European Worldeconomy in the Sixteenth Century. New York: Academic Press. 
Watts, Julian

2002 Heritage and Enterprise Culture in Archangel, Northern Russia. In Markets and Moralities: Ethnographies of Postsocialism. Ruth Mandel and Caroline Humphrey, eds. Pp. 53-74. Oxford, UK: Berg.

Weber, Max

2006 [1925] Bureaucracy. In The Anthropology of the State: A Reader. Aradhana Sharma and Akhil Gupta, eds. Malden, Mass.: Blackwell.

Weinreb, Amelia Rosenberg

2009 Cuba in the Shadow of Change: Daily Life in the Twilight of the Revolution. Gainesville, Fla.: University Press of Florida.

Whitney, Robert

2001 State and Revolution in Cuba: Mass Mobilization and Political Change, 1920-1940. Chapel Hill, N.C.: University of North Carolina Press.

Yurchak, Alexei

2006 Everything Was Forever, Until It Was No More: The Last Soviet Generation. Princeton, N.J.: Princeton University Press.

Ziff, Trisha

2002 Korda's Che. Online exhibition. Mexico City. http://zonezero.com/kordasche/introen.html, accessed May 22, 2013. 